DEPARTMENT OF THE INTERIOR

U.S. GEOLOGICAL SURVEY

NEW INFORMATION RESOURCES OF THE U.S. GEOLOGICAL

SURVEY LIBRARY SYSTEM.

Open-file Report 86-400-D-E

This report is preliminary and has not been reviewed for conformity with the U.S. Geological Survey editorial standards. 
This is the last issue of New Information Resources you will receive unless you request continued receipt by return of the following coupon. Please mail it to Bob Reed, Chief, Cataloging Section, USGS Library System, National Center - MS 950, Reston, VA 22092 or phone Bob at (703) 648-4486.

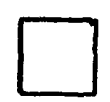
Please continue sending New Information Resources. Address corrections are noted below.

Name

Address

This is the last issue of New Information Resources you will receive unless you request continued receipt by return of the following coupon. Please mail it to Bob Reed, Chief, Cataloging Section, USGS Library System, National Center - MS 950, Reston, VA 22092 or phone Bob at (703) 648-4486.

Please continue sending New Information

Resources. Address corrections are noted below.

Name

Address

\section{* * * NOTICE TO USERS * * *}

This is the last issue of New Information Resources you will receive unless you request continued receipt by return of the following coupon. Please mail it to Bob Reed, Chief, Cataloging Section, USGS Library System, National Center - MS 950, Reston, VA 22092 or phone Bob at (703) 648-4486.

$\square$ Please continue sending New Information Resources. Address corrections are noted below.

Name

Address 
$* * * *$ This is the LAST ISSUE of New Information Resources that you will receive, unless you return one of the coupons on the next page or telephone Bob Reed, Chief of the Cataloging Section, at (703) 648-4486. The coupon/calls may also be used for requesting individual receipt.

LS/2000, the Library System's computer capability, has a new search access point to aid Survey researchers. It is a form subject heading called USGSPUB, and it will provide a listing of all publications issued by the Survey that are on the database. All current titles being cataloged have the tag added, and we are in the process of adding it retrospectively to titles already in the database. The goal is to be able to retrieve all USGS publications by use of this subject search device.

The LS/2000 staff is preparing an error reporting form for users. If you will let us know of errors you find in the database, the staff will correct them, to the benefit of all. Look for the forms at the public access terminals.

As frequently occurs in conjunction with incidents in lesser known parts of the world, the U. S. air strike on Libya resulted in a surge of requests to the Library System for information, including one for maps from the NBC Washington Evening News. The Reston Library posts large maps of areas in the earth science news on the bulletin board immediately to the right of the main entrance to the Library. The current display is of the Chernobyl, Russia area.

The Reston Library has a translation. service covering French, German, Italian, Portuguese, Spanish and Russian. Work is currently done in-house by Nora Tamberg and Dorothy Vitaliano. In calendar year 1987, the capability will be supplemented by contracts. Contact Carol Messick, 6089, for arrangements.

On May 2, Michael Kubisiak retired from the USGS Library System after 29 years of Federal service. Mike had presided over the acquisitions operations of the Library for about 18 years. The Library Staff honored Mike with a farewell "bash" on Friday, May 2, at which Henry Spall, Associate Chief of OSP, presented him with a Superior Service Award. Mike's in-depth knowledge of acquisitions and his infectious good humor will be greatly missed.

Margaret (Peggy) Merryman has been named Acting Chief, Exchange and Order Section, (acquisitions) effective May 5, 1986.

\section{STAFF BIOGRAPHICAL NOTES}

Harry Allan, Interlibrary Loan Technician, has been with the Reston library since July, 1983. He has a B.S. in Political Science from Catawba College, Salisbury, N.C. Harry's work is part of our resource sharing with other libraries.

Karla Anderson joined the Reston staff in 1979 working during the summers as a Junior Federal Fellow. After receiving her B.A. in French from the College of William and Mary in 1983 she became a full-time senior technician in the Exchange and Order Section. Karla's work is part of our collection management program. In her free time she also volunteers as an usher at the Wolf Trap Farm Park for the Performing Arts. 
Libraries in the Geological Survey Library System are located in the Eastern, Central, and Western Regions. Personnel whose duty station is other than Reston, Denver, Menlo Park or Flagstaff, may borrow items by completing an Accessions List Loan Request form and mailing it to the Survey Library in their Region if the item is available there or to the nearest Survey Library holding the item if it is not. Personnel whose duty station is Reston, Denver, Menlo Park or Flagstaff should continue to request items as they are accustomed to doing.

If a library is unable to fill a request immediately because its copy of the item is charged out or otherwise unavailable for loan, the request will be forwarded to any Survey Library which may be able to supply a copy. If no copy is available for immediate loan, the requester's name will be placed on a waiting 1 ist and the publication dispatched as soon as it becomes available. Publications with a waiting list are loaned for two weeks only; those without are loaned for thirty days. If there is no waiting list, the loan period may be extended by contacting the lending library prior to the expiration of the loan period and requesting a renewal.

In filling out the Loan Request form, it is essential that requesters include their (1) Division/Office/Branch affiliation, (2) complete mailing address, and (3) phone numbers, both commercial and FTS. Typing or printing such information will help avoid unnecessary delays in processing requests. Loan Request forms will be found at the end of each List; they should be duplicated if additional copies are required. A separate form should be used for each item requested.

Questions regarding entries in the List or the information to be supplied on the Loan Request form should be referred to the Library located in the same Region as the requester's duty station.

\begin{tabular}{|c|c|c|}
\hline Eastern Region & Central Region & Western Region \\
\hline $\begin{array}{r}\text { Reston Library } \\
(703) \quad 648-4302 \\
4303\end{array}$ & $\begin{array}{l}\text { Denver Library } \\
\text { (303) } 236-1000\end{array}$ & $\begin{array}{l}\text { Menlo Park Library } \\
\text { (415) } 323-8111, \\
\text { ext. } 2207\end{array}$ \\
\hline $\begin{array}{r}959-4302 \\
4303\end{array}$ & $776-1000$ & $467-2207$ \\
\hline
\end{tabular}

Flagstaff Library

(602) $527-7008$

FTS $\quad 765-7008$

Suggestions and comments about this service are welcome and should be sent to:

Chief Cataloger

U.S. Geological Survey Library

950 National Center

Reston, Virginia 22092 
$(200)$
8290
Do.83-405
D, ip

DI-GS I4 JOL 83 EJP
Crock, J. 6 .

Major, minor, and erace elenento in

eaples tron the Theelor olldernese

Study Area, Coloredó ó daterelned

by I ductively coupled areon pläm

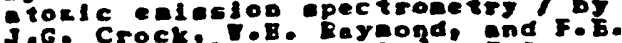

ilchte. Crock' Denver, co

Goologicel survey, 1883.

1. 24 leaves: $28 \mathrm{~cm}-10 \mathrm{per}$

the report $/$ Dalted ste tee

Deportacnt of the Interlor;

Gepiocleal survey 83-505

Chiesiy tables.

Bibilography: ieas 8.

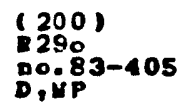

DI-GS I4 JOL 83 EJP

GISsa

The above is a photocopy of a main entry card which is representative of the format arrangement appearing on cards filed in the Reston, Denver, Menlo Park and Flagstaff Library catalogs.

Appropriate information is selected and reformatted to produce subjectarranged entries similar to the following.

Personal

author

Primary subject heading
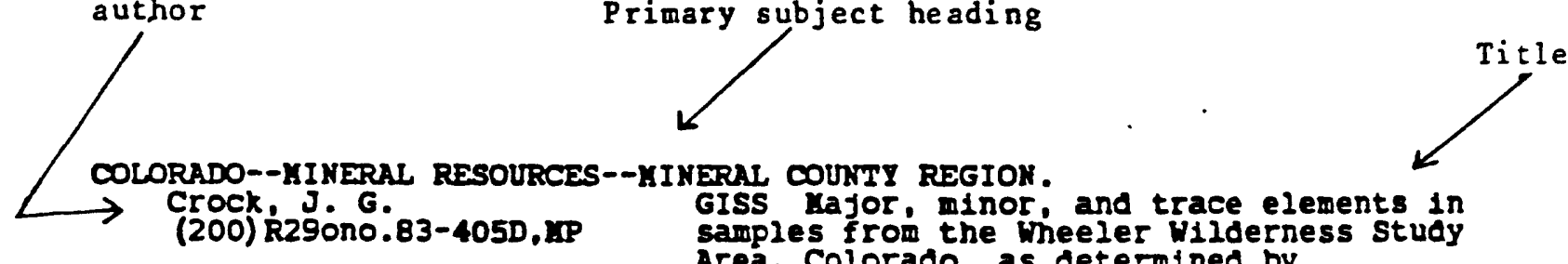

(200) R290no.83-405D, LAP

GISS Major, minor, and trace elements in

samples from the Wheeler Wilderness Study

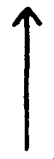

USGS Library Call No. indicating that Reston, Area, Colorado, as determined by inductively coupled argon plasma-atomic emission spectrometry. 1983

Denver, and Menlo Park

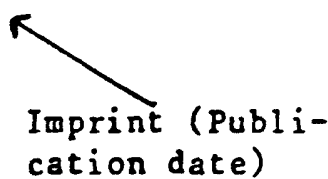

each have this item

COSMOCHEMISTRY - - CONGRESSES . $730.3 C 822$
Title main entry<smiles>[Li]</smiles>

GISS Cosmochemistry and the origin of life : proceedings of the NATO Advanced study institute held at Karatea. Italy, June 112. 1981 . 1983 
Additional explanation beyond that provided by the preceding examples seems appropriate.

Each entry consists of the following components which always appear in the order given: (1) Principal subject heading, always capitalized; (2) Main entry, which may be a personal author, corporate author, or title; (3) Title (if the main entry is either a personal or corporate author); (4) Imprint; (5) USGS call no., always located in the lower left and the last component in each entry.

The call number on catalog cards normally consists of two or more lines of a combination of letters and numbers, arranged in the following manner:

$$
\begin{aligned}
& \text { G(253) } \\
& \text { F46 } \\
& \text { v. } 37 \\
& \text { no. } 4 \\
& \text { D, MP }
\end{aligned}
$$

In the Accessions List the same number appears in a straight 1 ine. There are no spaces to show where the call no. lines are broken on the catalog cards: G(253)F46v.37no.4D,MP

Call numbers prefixed with " $M$ " indicate item is part of the map collection.

Call numbers prefixed with "R" indicate item is part of the Library's Reference collection. These items normally do not circulate.

Capital letter suffixes denoting which libraries ( $D=$ Denver, $M P=$ Menlo Park, and $F=$ Flagstaff), other than Reston, hold a particular item, follow the call no. and are set off from it by a space. Please note that no letter suffix is employed for Reston, which should be understood to hold the item unless otherwise indicated. In the call no. above, the Reston, Denver, and Menlo Park libraries each have this item.

If a library, other than Reston, is the sole holder of an item, the suffix statement will reflect that fact; for example: F only.

Occasionally an item will not be assigned a call no., receiving instead an alpha abbreviation, such as PAM = pamphlet or MICRO = microform. In such entries, that designation occupies the space normally set aside for the call no. When completing the Loan Request form, alpha abbreviations should be recorded on the call no. line. 
TO: Recipients of the USGS Library New Information Resources Lists

Because of the many changes and the reorganization of various Divisions and Offices within the Geological Survey, please notify the Library at the address 1 isted below of any address changes to be made and also any changes in the number of NIR Lists that are needed by your office.

Thank you.

Bob M. Reed, Chief Cataloger

U.S. Geological Survey Library

Mail Stop 950

12201 Sunrise Valley Drive

Reston, Virginia 22092

TO: Recipients of the USGS Library New Information Resources Lists

Because of the many changes and the reorganization of various Divisions and offices within the Geological Survey, please notify the Library at the address listed below of any address changes to be made and also any changes in the number of NIR Lists that are needed by your office.

Thank you.

Bob M. Reed, Chief Cataloger

U.S. Geological Survey Library

Mail Stop 950

12201 Sunrise Valley Drive

Reston, Virginia 22092

TO: Recipients of the USGS Library New Information Resources Lists

Because of the many changes and the reorganization of various $D i v i$ sions and offices within the Geological Survey, please notify the Library at the address $l$ isted below of any address changes to be made and also any changes in the number of NIR Lists that are needed by your office.

Thank you.

Bob M. Reed, Chief Cataloger

U.S. Geological Survey Library

Mail Stop 950

12201 Sunrise Valley Drive

Reston, Virginia 22092 
TO: Recipients of the USGS Library New Information Resources Lists

Please use this coupon to make recommendations for publications to be added to the collections within the Survey Library system.

Author:

Title:

Series no.:

Publisher:

Date :

TO: Recipients of the USGS Library New Information Resources Lists

Please use this coupon to make recommendations for publications to be added to the collections within the Survey Library system.

Author:

Title:

Series no.:

Publisher:

Date:

TO: Recipients of the USGS Library New Information Resources Lists

Please use this coupon to make recommendations for publications to be added to the collections within the Survey Library system.

Aut hor:

Title:

Series no.:

Publisher:

Date:

8 
Bulletin de l'Institut scientifique (Jāmiat Munammad al-Khāmis. Makad alIImi). Bulletin de I'Institut scientifique. Rabat : L'Institut, 1976$S(740)$ B 874

ACID RAIN--ENVIRONMENTAL ASPECTS--CONGRESSES.

Acidic deposition, trace contaminants and their indirect human health effects research needs : workshop proceedings, held June 19-22, 1984 at Topridge Conference Center, Paul Smith's, New York. [Albany, N.Y.] : The Department, [1985]

583.1 Ac48W

AERIAL PHOTOGRAMMETRY--MATHEMATICS.

Smirnov, Sergei Aleksandrovich. Stereoperspektiva v fotogrammetrii. Moskva : Nedra, 1982.

$753.5 \mathrm{Sm} 48 \mathrm{~s}$

AFRICA, EAST--NATURAL RESOURCES--LAW AND LEGISLATION.

Lejal aspects of protecting and managing the marine and coastal environment of the East African region. Geneva, Switzerland : Regional Seas Programme Activity Centre, United Nations Environment Programme, 1983.

537.5 qun22 no.38

AGGREGATES (BUILDING MATERIALS)--ONTARIO--SUDBURY AREA.

Proctor $\varepsilon$ Redfern, Ltd. Sudbury area mineral aggregate study. [Toronto]: The Ministry, 1978.

$403(150)$ Su22 D only

AIRGLOW.

Fishkova, L. M. Nochnoe izluchenie sredneshirotnoì verkhne i atmosfery Zemli. Tbilisi : MeEŝniereba, 1983.

511 F538n

ALASKA--GEOLOGY--CHUGACH NATIONAL FOREST--MAPS.

Nelson, Steven $w_{.}$Geologic map of the Chugach National Forest, Alaska.

Reston, Va.: U.S. Geological Survey, 1985.

M(286) 2 C472n -- M(200) 4 vUn 3mf no.1645-B -- M(200) MF no.1645-B

ALASKA--PALEONTOLOGY--MAPS.

Detterman, Robert L. Megafossil locality map, checklists, and Pre-

Quaternary stratigraphic sections of Ugashik, Bristol Bay, and part of Karluk quadrangles, Alaska. Reston, Va. : U.S. Geological Survey, 1985. M (286) 6 Ug2d -- M(200) 4 vUn3mf no.1539-B -- M(200) MF no.1539-B

ALASKA--PUBLIC LANDS--LAW AND LEGISLATION.

Alaska National Interest Lands Conservation Act : as amended, with an introduction and subject index. [Washington, D.C.?]: U.S. Dept. of the Interior, Office of Information Resources Management, Division of Information and Library Services, 1985. $585.5(286)$ Un33ai

ALASKA--WATER-SUPPLY--SOUTHCENTRAL REGION .

Southcentral Alaska water resources study (Level B) : phase 1 technical memorandum, water supply. Anchorage : The Committee, [1979] $780(286)$ So88d 
ALGAE--ARAL SEA.

Elmuratov, A. E. Fitoplankton îuzhnnoi chasti Aralskogo morîa.

Tashkent : Izd-vo Fan Uzbekskoi SSR, 1981.

$554(068)$ El65f

AMMONOIDEA.

Atabekiân, A. A. Turrilitidy pozanego alba i senomana iuga SSSR.

Leningrad : Nauka, Leningradskoe otd-nie, 1985.

(570) T765msk t.14

ANDALUSITE--SOUTH AFRICA--THABAZIMBI REGION.

overbeek, $P$. W. Beneficiation tests on andalusite-bearing shales from a farm near Thabazimbi. Randburg, S.A. : Council for Mineral Technology, 1984 .

$S(787)$ qN213r no.M43d

APPALACHIAN MOUNTAINS, SOUTHERN--GEOLOGY--GUIDEBOOKS.

The Geologic history of the Thorn Hill Paleozoic section (Cambrian Mississippian), eastern Tennessee. Knoxville, Tenn. : University of Tennessee, 1985.

$G(200)$ qG3sef 1985 no.6

APPALACHIAN REGION--GEOLOGY--GUIDEBOOKS.

McKenzie, Garry D. Field guide to the geology of parts of the Appalachian Highlands and adjacent Interior Plains. Columbus, Ohio : Zip Services, Inc. 1985 .

$203(220)$ M198f

AQUIFERS--MAINE--YORK COUNTY - MAPS.

Hydrogeology of significant sand and gravel aquifers : Northern York and Southern Cumberland Counties, Maine. [Augusta] : Maine Geological Survey, 1983.

$M(211) 49$ Y82t

ARCHAEOLOGY --PERIODICALS.

Geoarchaeology. Geoarchaeology. New York, N.Y. : John Wiley, 1986-

$679.9 \mathrm{G} 288$

ARIZONA--GEOLOGY--COLORADO PLATEAU.

Condit, Christopher D. The geology of the western part of the

Springerville volcanic field, east-central Arizona. 1984.

$203(274)$ C754g F only

ARIZONA--MINERAL RESOURCES--COCHISE COUNTY.

Zelten, Jeanne $\mathrm{E}$. Mineral resources of $a$ part of the Dos Cabezas Mountains Wilderness Study Area (AZ-040-065), Cochise County, Arizona. IWashington, D.C. ] : United States Department of the Interior, Bureau of Mines, 1986. $402(200)$ un $34 \mathrm{msi}$ no.2-86

ARKANSAS--GEOLOGY - -GUIDE-BOOKS .

A guidebook to the geology of the Arkansas Paleozoic area (Ozark Mountains, Arkansas Valley, and Ouachita Mountains). Rev. Little Rock, Ark. : State of Arkansas, Arkansas Geological Commission, 1980.

(241) Ar7g no.77-1

ARKANSAS--GEOLOGY - -OUACHITA MOUNTAINS.

Stone, Charles G. A guidebook to the geology of the central and southern Ouachita Mountains, Arkansas. Little Rock, Ark. : Arkansas Geological Commission, [1984]

(241) Ar7g no.84-2 
ARKANSAS--GEOLOGY--OUACHITA MOUNTAINS--GUIDE-BOOKS .

Stone, Charles G. Field guide to the Paleozoic rocks of the Ouachita Mountain and Arkansas valley Provinces, Arkansas: [guidebook for] Geological Society of America annual meeting at New Orleans, Louisiana, October, 1982. [Little Rock, Ark.]: Arkansas Geological Commission, [1982]

(241) Ar7g no.81-1

ASIA--MINERAL RESOURCES--CONGRESSES.

Asian mining 185 : papers presented at the Asian mining 85 conference organized by the Institution of Mining and Metallurgy in association with the Chamber of Mines of the Philippines, and held in Manila from 11 to 14 February, 1985. London : The Institution, cl985.

401 (600) qÁsi2p 1985 MP

ASTRONAUTICS--INTERNATIONAL COOPERATION.

UNISPACE ' 82 : a context for international cooperation and competition : a technical memorandum. Washington, D.C.: Congress of the U.S., Office of Technology Assessment : For sale by the Supt. of Docs., U.S. G.P.0.. [1983] $P(200)$ c728un

ATLASES .

Hammond Incorporated. Hammond/Simon $\varepsilon$ Schuster world atlas. [New York] : Simon and Schuster, c1984.

R 508 qH184hs

ATMOSPHERE, UPPER--CONGRESSES.

Vsesoiuznoe soveshchanie po issledovanifû dinamicheskikh protsessov $v$ verkhnei atmosfere (3rd: 1979 : Obninsk, R.S.F.S.R.) . Issledovanie dinamicheskikh profsessov $v$ verknnei atmosfere : trudy Tretégo vsesoiuznogo soveshchaniia po issledovanifu dinamicheskikn protsessov $v$ verkhnej atmosfere. Moskva : Moskovskoe otd-nie Gidrometeoizdata, 1983.

511 v968i

ATMOSPHERE, UPPER--KIRGHIZISTAN .

Karimov, K. A. Vnutrennie gravitaEșionnye volny $v$ verkhneI atmosfere. Frunze : Ilim, 1983.

$511(695.6) \mathrm{K} 146 \mathrm{v}$

ATOMIC ABSORPTION SPECTROSCOPY--PERIODICALS.

Journal of analytical atomic spectrometry. Journal of analytical atomic spectrometry. London : The Society, 1986-

886 qJ826a

BAHAMAS--GEOLOGY .

Symposium on the Geology of the Bahamas (1st : 1982 : San Salvador, Bahamas). Proceedings of the First symposium on the Geology of the Bahamas : March 2325, 1982, San salvador, Bahamas. San Salvador, Bahamas : College Center of the Finger Lakes. Bahamian Field Station, 1982.

203 (395) Sy68b

BAHAMAS--GEOLOGY--CONGRESSES.

Symposium on the Geology of the Bahamas (2nd: 1984 : San Salvador, Bahamas). proceedings of the second Symposium on the Geology of the Bahamas : June $16-$ 20, 1984, San Salvador, Bahamas. San Salvador, Bariamas : College Center of the Finger Lakes, Bánamian Field Station, 1984.

201 (395) Sy68p 1984 
BALTIC SEA--GEOLOGY--ADDRESSES, ESSAYS, LECTURES.

Geologicheskaia istoriia i geoknimi ia Baltiiskogo morîa. Moskva : Nauka, 1984.

$298(057)$ G292i

BAUXITE--PALAU ISLANDS .

Ikebe, Takisaburo. Dressing test of bauxite ore in Palau Island. [Tokyo, Japan : U.S. Geological Survey, Pacific Geological Surveys, 1937] $209(900)$ qun33pr [no.482]

Tashiro, Shuichi. Bauxite in Palau. [Tokyo, Japan : U.S. Geological Survey, Pacific Geological Surveys, 19--1

$209(900)$ qun33pr [no.48I]

BELGIUM .

Belgium, a country study. 2nd ed. Washington, D.C. : for sale by the Supt. of Docs., U.S. G.P.O., cl984.

504 (593) Am35a 1985

BELGIUM--GEOLOGY--CAMPINE.

Tys, E. De geologische struktuur van het steenkoolterrein ten noorden van het ontginningsgebied der kempense mijnen : voorlopige senthese en

Probleemstellingen. Brussel, Belgium : Geologische dienst van Belgie, 1980.

(593) qPp 1980 no.9

BIBLIOGRAPHY--EARTH SCIENCES--NEVADA.

Mackay School of Mines. Thesis list, 1908-1983: 75 th anniversary edition. Reno, Nev, Mines Library, University of Nevada-Reno, [1984]

$043(275)$ M192t

BIBLIOGRAPHY --GEOLOGY --MAPS--PERIODICALS .

Géocarte information. Géocarte information, orleans, France : Dép. documentation et information géologiques, 1984-

$042.759 \mathrm{G} 292$

BIBLIOGRAPHY - -GEOM ICROBIOLOGY .

West, J.M. Geomicrobiology and its relevance to nuclear waste disposal : a further annotated bibliography. Keyworth, England : British Geological Survey, 1984 .

(510) qR298 FLPU no.84-9

BIBLIOGRAPHY--NATURAL RESOURCES--CANADA.

Pal, Gabriel. How to find information on Canadian natural resources : a guide to the literature. Ottawa : Canadian Library Association, 1985.

R $042.580(100)$ P $172 \mathrm{~h}$

BIBLIOGRAPHY--REMOTE SENSING--GEOLOGY

Simpson, Shirley L. Selected geological and geophysical remote sensing publications by U.S. Geological survey authors 1961-1984. [Denver, Co10.]: U.S. Geological survey, 1986 .

(200) R290 no.86-4I D MP

BIBLIOGRAPHY--SEWAGE DISPOSAL--NEW ZEALAND.

Church, Denise F. Liquid and waterborne waste research in New Zealand 1978. Wellington, N.Z. : Published for the National water and Soil Conservation organisation by the Water and Soil Division, Ministry of Works and Development, 1980.

$\mathrm{P}(890)$ qW292mp no.ii 
BIBLIOGRAPHY--UKRAINE--GEOLOGY .

Ukrainskaía SSR : Zapadnye oblasti, period 1966-1970, X. Kiev : Nauk. dumka, 1985.

(570) G22 t.3i vyp.I 1966-70

Ukrainskâià SSR : TSentralhye i Vostochnye oblasti, period X 1966-1970. Kiev : Nauk. dumka, 1982-

(570) G22 t.32 vyp.1 1966-70 D

BIBLIOGRAPHY--WATER QUALITY--NEW ZEALAND.

Biggs, B. J. Water quality research in New Zealand 1979. Wellington : Published for the National Water and Soil Conservation Organisation by the Water and Soil Division, Ministry of Works and Development, 1980.

$P(890)$ qW292mp no.20

BIBLIOGRAPHY--WATER RESOURCES DEVELOPMENT--SOVIET UNION .

Kuksin. I. E. Vodnye resursy, ikh ispolzovanie i okhrana :

bibliograficheskij ukazatel' literatury za $1980 \mathrm{~g}$. Minsk: TSNII

kompleksnogo ispolzovaniia vodnykh resursov : Fundamental naía

biblioteka im. IA. Kolasa AN BSSR, 1981 .

$042.784(570) \mathrm{K} 958 \mathrm{~V} 1981$

BIOGEOGRAPHY . Hillman, Peter. The basics of biogeography. London : Edward Arnold,

918 H558b

BIRDS, FOSSIL.

Kurochkin, E. N. PtiESy TSentralhoí Azii v plioEs̀ene. Moskva : Nauka, 1985.

$680(619)$ So92t vyp.26

BIRDS, FOSSIL--CONGRESSES.

International Archaeopteryx Conference (1984 : Eichstätt, West Ger.). The beginnings of birds : proceedings of the International Archaeopteryx Conference, Eiçhstatt 1984. Eichstatt [West Germany] : Freunde des JuraMuseums Eichstatt, Willibalasburg, 1985.

$677(530)$ In8b 1985

BITUMEN--GEOLOGY--ADDRESSES, ESSAYS, LECTURES.

The Geology of bitumens and bitumen-bearing rocks = Geologiîa bitumov i bitumovmeshchaîushchikh porod. [Reston, va.] : The Survey, [1985] $460(570)$ G292E

BORING--SAFETY MEASURES--HANDBOOKS, MANUALS, ETC. .

Driller's safety manual. Reprint. Denver, Colo. : U.S.G.P.O., 1982. 777 un 36 d

BORINGS--MONTANA--ROSEBUD COUNTY REGION .

Hansen, William B. Correlated lithologic logs and analyses of 1982 coal driliing in Big Horn, Prairie, Rosebud, and Treasure Counties, Montana. [Denver, COl: U.S. Geologicai Survey, 1985.

(200) R29o no.85-738 D MP

BORINGS--PENNSYLVANIA--NEW HOPE REGION.

Ratcliffe, Nicholas M. Preliminary results of coring of the Furlong Fault near Lake Aquetong, New Hope, Pennsylvania. [Reston, VA] : U.S. Geological survey, [1986]

(200) R290 no.86-43 D MP 
BOTANY--ADDRESSES, ESSAYS, LECTURES

Chamisso, Adelbert von. Adelbert von Chamisso ... und lassen gelten, was ich beobachtet habe : naturwissenschaftlich Schriften mit Zeichnungen des Autors. Berlin, Germany : Dietrich Reimer, 1983.

929 C357a

BOUNDARY LAYER (METEOROLOGY) --MATHEMATICAL MODELS.

Lee, Chong Bum. Modelling and climatological aspects of convective boundary layer. Ibaraki, Japan : The University of Tsukuba Environmental Research Center, 1985.

$\mathrm{S}(620)$ En92 no.7

BRACHIOPODA, FOSSIL--YUGOSLAVIA.

Sucić-Protić, Zora. Mesozoic brachiopoda of Yugoslavia : Middle Liassic brachiopoda of the Yugoslav Carpatho-Balkanids (part III) = Mezozojski brahiopodi Jugoslavije : Srednjolijaski brahiopodi Jugoslovenskin KarpatoBalkanida (deo III). Zagreb : Jugoslavenska Akademija Znanosti i Umjetnosti, [1985]

$602(596)$ qPI74 Sv.32

BRITTANY--GEOLOGY--PERIODICALS.

Hercynica. Hercynica. Rennes : La Société, 1985-

$G(540)$ qH 418

BRYOZOA, FOSSIL--UTAH .

Karklins, Olgerts L. Chesterian (Late Mississippian) Bryozoans from the upper Chainman Shale ad the lowermost Ely Limestone of western Utah. [Washington, D.C.] : The Paleontological Society, Inc., [1986] G(200) J83pm no.i7

BUSINESS--DATA PROCESSING--PERIODICALS.

Ashton-Tate quarterly. Ashton-Tate quarterly. Inglewood, CA : AshtonTate, c1985-

039.2 As 38

CALCIUM CHLORIDE--CALIFORNIA.

Majmundar, Hasmukhrai H. Mineral commodity report, calcium chloride. Sacramento, Calif. : California Department of Conservation, Division of Mines and Geology, 1985.

(276) qC4spp no.80

CALIFORNIA--GEOLOGY--CALAVERAS COUNTY--MAPS.

Peterson, Jocelyn A. Geologic map of the Penn Mine, Calaveras County, California. Reston, Va.: U.S. Geological Survey, 1985.

M (276) 2 P382p -- M (200) 4 vUn3mf no.1797 - M (200) MF no.1797

CALIFORNIA--GEOLOGY--CHOLAME RANCH REGION.

Hay, Edward A. Geology of the Cholame Ranch quadrangle, California. 1961.

$209(276) \mathrm{H} 322 \mathrm{~g}$ MP only

CALIFORNIA--GEOLOGY--DUBAKELLA MOUNTAIN QUADRANGLE--MAPS .

Reconnaissance geologic map of the Dubakella Mountain quadrangle, Trinity, Shasta, and Tehama Counties, California. Reston, Va. : U.S. Geological Survey, 1985.

M (276) 2 D852i - M (200) 4 vUn3mf no.1808 -- M (200) MF no. 1808 
CALIFORNIA--GEOLOGY--HYAMPOM QUADRANGLE--MAPS.
Irwin, William P. Reconnaissance geologic map of the Hyampom quadrangle,
Trinity County, California. Reston, va. : U.S. Geological survey, 1985.
M(275) 2 H992i - M (200) 4 vUn3mf no.1809-- M(200) MF no.1809

CALIFORNIA--MINERAL RESOURCES--KLAMATH MOUNTAIN REGION--MAPS.

Kennedy, George L. Mineral resource potential map of the Tunnel Ridge Wilderness Study Area, Klamath Mountains, California. Reston, Va.: U.S. Geological Survey, 1985.

M (276) 4 T835k -- M(200) 4 vUn3mf no.1810-A -- M(200) MF no.1810-A

CANADA--GEOLOGY--COLLECTED WORKS.

Open file report (Canada. Indian and Northern Affairs). Open file report. [Ottawa] : Indian and Northern Affairs. $P(100)$ N820

CANADA--MINERAL RESOURCES.

Cranstone, Donald A. Mineral exploration in Canada : questions and answers for the nonexpert. [Canada] : Energy, Mines and Resources Canada : Minister of Supply and Services Canada, 1985.

$402(100)$ Cl8mr no.208

CAOL--POWDER RIVER BASIN, WYO. AND MONT.--RESERVES.

Trent, Virgil A. Summary of results of the Coal Resource Occurrence and Coal Development Potential mapping program in part of the Powder River Basin, Montana and Wyoming. [Reston, VA] : U.S. Geological Survey, 1985. (200) R290 no.85-621 D MP

CARBONATES--SOVIET UNION.

Prirodnaîa soda i davsonitoproîavleniia v SSSR. Moskva : Nauka, 1985. $459(570)$ P938s

CARTOGRAPHY--COMPUTER PROGRAMS.

Spann, G. William. Computer land use mapping from ERTS : final technical report, project A-1557. Atlanta, Ga, Engineering Experiment Station, Georgia Institute of Technology, [1974] 759.5 Sp24C

CAUSTOBIOLITHS--ADDRESSES, ESSAYS, LECTURES.

Sistemnye issledovaniia v geologii kaustobiolitov. Moskva : Nauka, 1984. $464.1 \mathrm{Si} 84$

CAVES--MINNESOTA--GUIDEBOOKS.

An Introduction to caves of Minnesota, Iowa, and Wisconsin : guidebook for the 1980 National Speleological Society Convention, Lakewood Community College, White Bear Lake, Minnesota. [s.l.] : National Speleological Society, 1980

$s(200)$ N2ig no.ì

CAVES--OREGON--BEND REGION--GUIDEBOOKS.

An Introduction to caves of the Bend area. Huntsville, Ala. : National speleological society, cig82.

$\mathrm{S}(200) \mathrm{N} 27 \mathrm{~g} 1982$

CAVES--SPAIN--VIZCAYA.

Catalogo de cuevas de vizcaya = Bizkaiko haitzuloen katalogia. Bilbao, [Spain] : Diputación Foral de Vizcaya, 1985.

$547(560)$ C282 
CIVILIZATION--HISTORY .

Calder, Ritchie. After the seventh day : the world man created. New York, Simon and Schuster, 1961.

030 Cl27a

CLOUDINESS.

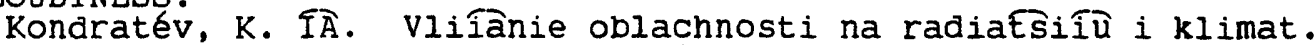
Leningrad : Gidrometeoizdat, 1984.

$511 \mathrm{~K} 837 \mathrm{~V}$

COAL--GEOLOGY--MANCHURIA.

Ōnuki, Yoshio. North Ta-túng coal field. Tokyo, Japan : U.S. Geological survey, [1953]

$209(900)$ qun $33 \mathrm{pr}$ [no.480]

COAL--GEOLOGY--YUGOSLAVIA--METOHIJA.

Bokčić, Predrag L. Neogena ugljena ležišta severoistočnog dela Metohijskog basena (geneza $i$ osobine) $=$ Neogene coal deposits northeast in the Metohija Basin (genesis and character). Beograd [Yugoslavia] : Zavod za geoloska i geofizicka istrazivanja, 1983.

(596) qR no.20

COAL MINES AND MINING--ALABAMA--TUSCALOOSA COUNTY--ENVIRONMENTAL ASPECTS .

Kidd, Robert E. Application of the precipitation-runoff model in the Warrior Coal Field, Alabama. Tuscaloosa, Ala. : U.S. Geological Survey, 1986.

(200) R290 no.85-678 D MP

COAL MINES AND MINING--ENVIRONMENTAL ASPECTS--KENTUCKY .

Evangelou, V. P. Identification of soil-water chemical parameters for the prediction and treatment of suspended solids in surface water reservoirs of coal mine lands. Lexington, $\mathrm{Ky}$. : Water Resources Research Institute, University of Kentucky, 1985.

$\mathrm{s}(238)$ qK4wrr no.160

COAL MINES AND MINING--OKLAHOMA--MAPS.

Friedman, S. A. Map of eastern Oklahoma showing locations of active coal mines, 1977-79. Norman, Okla. : Oklahoma Geological Survey, 1982 .

M (244) $4611982 f$

Friedman, S. A. Map showing potentially strippable coal beds in eastern Oklahoma. Norman, Okla. : Oklahoma Geological Survey, 1982.

M (244) 461 i $983 \mathrm{f} \mathrm{S}$

Johnson, Kenneth S. Maps and description of disturbed and reclaimed surfacemined coal lands in eastern Oklahoma, showing acreage disturbed and reclaimed through June, 1973. Norman, Okla.: Oklahoma Geological Survey, 1974.

M (244) $4611974 j$

COAL MINES AND MINING--UNITED STATES.

King, Robert $H$. Summary of advanced technology research in continuous underground coal mining methods, 1946-1978. Golden, Colo. : Colorado School of Mines press, c1985.

$\mathrm{S}(271)$ C78m v.26 no.6

COAL--MONTANA--BEAVERHEAD COUNTY--MAPS .

Dyni, John R. Tertiary coals in Medicine Lodge Creek Valley, Beaverhead County, Montana. [Butte] : Montana Bureau of Mines and Geology, 1982.

M(281) 461 M468d 
COAL-OKLAHOMA--SPIRO QUADRANGLE--MAPS .

Geological Services of Tulsa. Federal coal resource occurrence map of the Spiro 7.5 minute quadrangle, Leflore County, Oklahoma. [Reston, va.] : U. S. Geological Survey, 1985.

M (244) 461 Sp48g -- (200) R290 no.79-496 -- (200) R290 no.79-496

COAL TRADE--COLORADO.

Rushworth, Peter. Analysis of the Colorado coal industry. Denver, CO : Colorado Geological Survey, 1984.

(271) qC3sp no.24

COAL--UTAH--CARBON COUNTY--MAPS.

Anderson, Paul Bradley, Geologic map of the Pine Canyon quadrangle, Carbon County, Utah. Salt Lake City, Utah : Utah Geological and Mineral Survey, 1983 .

M (273) 2 P653a

COALBED METHANE DRAINAGE--UTAH--CARBON COUNTY.

Molinda, Gregory M. Investigation of similarities between methane drainage potential of Utah's Sunnyside Coalbed and eastern U.S. coalbeds.

TWashington, D.C.] : U.S. Dept. of the Interior, Bureau of Mines, 1985.

$402(200)$ Un 34 ex no.9007

COAST CHANGES--QUEENSLAND--TRINITY BAY REGION.

Jones, M. R. Quaternary geology and coastline evolution of Trinity Bay, north Queensland. Brisbane : Geological survey of queensland, 1985.

(810) qD no.386

COASTAL ECOLOGY--AFRICA, EAST.

Conservation of coastal and marine ecosystems and living resources of the East African region. Geneva, Switzerland : Regional Seas Programme Activity Centre, UNEP, 1982.

537.5 qun22 no. Il

COASTS--ARGENTINA--PATAGONIA REGION.

Planicie costera Bonaerense, Costa Norpatagonica : reunion de campo = Buenos Aires coastal plain, north Patagonia coast : field meeting : Argentina, 7-12 Oct.1984. [S.1.] : International Association for Quaternary Research,

$209.1(420)$ P692

COKE--INDIA--DAMODAR VALLEY.

Sanyal, S. P. Petrology of natural coke associated with igneous intrusives in parts of the Raniganj coalfield. Calcutta, India : Director General, Geological survey of Inaia, 1984.

(640) M no.117

COLORADO--GEOLOGY - - COLLBRAN QUADRANGLE--MAPS.

Donnell, John R. Preliminary geologic map of the Collbran quadrangle, Mesa County, Colorado. Reston, va. : U.S. Geological Survey, 1985.

$M(271) 2$ C685d - M (200) 4 vUn $3 \mathrm{mf}$ no.1825 - M(200) MF no.1825

COLORADO--NATURAL RESOURCES.

Upper Colorado resource study, Colorado and Utah : concluding report, May 1980. [Salt Lake City] : The Region, 1980. $580(27 i)$ Up7 
CONSERVATION OF NATURAL RESOURCES--AFRICA, EAST.

Marine and coastal conservation in the East African region. Geneva, Switzerland : Regional Seas Programme Activity Centre, United Nations Environment Programme, 1984.

537.5 qun22 no.39

CONSERVATION OF NATURAL RESOURCES--NEVADA.

United States. Bureau of Land Management. Carson City District Office. Lahontan resources management plan : record of decision and management decisions summary. Carson City : The Department, 1985. $585.3(275)$ Un $34 \mathrm{~d} 1 \mathrm{~m}$

CONTINENTAL DRIFT.

Rudich, E. M. Dvizhushchiesîa materiki i évoliûtîia okeanicheskogo lozha. Moskva : Nedra, 1983.

311 R833d

Ushakov, S. A. Dreíf materikov i klimaty Zemli. Moskva : Mysl'́, 1984. 311 Us 3 d D

CONTINENTAL MARGINS.

Shcherbakov, F. A. Materikovye okrainy $v$ pozdnem pleĭstoEs̀ene i golotsene. Moskva : Nauka, 1983. $352 \mathrm{Sh} 28 \mathrm{~m}$

CONTINENTAL SHELF--CALIFORNIA--MAPS.

MCCulloch, David S. Maps showing locations of selected Pre-Quaternary rock samples from 341p0is30'north latitude to 421 po isnorth latitude, California continental margin. Reston, Va.: U.S. Geological Survey, 1985 .

$\mathrm{M}(276) 5231985 \mathrm{~m}-\mathrm{M}(200) 4$ vUn $3 \mathrm{mf}$ no.17ig - M (200) MF no.1719

CONTINENTAL SHELF--UNITED STATES.

United States. Minerals Management Service. 5-year Outer Continental Shelf Oil and Gas Leasing Program for January 1987 - December 1991, decision and summary : proposed program. [Washington, D.C.] : U.S. Dept. of the Interior, Minerals Management Service, [i985]

R $402(200)$ M6620cpds 1986

COPPER.ORES - -FINLAND.

Etelä-Suomen svekokarjalaiset profyyrityyppiset molybdeeni- ja kupariesiintymat, niiden granitoidiisantakivet ja litogeokemiallinen estsinta = Svecokarelian prophyry-type molybdenum and copper occurrences in southern Finland; their granitoid host rocks and lithogeochemical exploration. Espoo [Finland]: Geologian Tutkimuskeskus, 1984.

(579) qRi no.67

COPPER ORES--MONGOLIA.

Mednoruanye formaEsii MNR / [Sotnikov V.I. ... i dr.]. Novosibirsk : Nauka, Sibirskoe otd-nie, 1985.

$203(600)$ So88t vyp. 43

CORALS, FOSSIL.

Ilína, Tamara Gennadévna. The historical development of corals : suborder Polycoeliina = Istoricheskoe razvitie korallov (podotriad Polycoeliina). [Reston, Va.] : The Survey, [1985]

$\mathrm{G}(570)$ ACI22pE $t .198$ 
COSMOLOGICAL DISTANCES.

Cadogan, Peter H. From quark to quasar : notes on the scale of the universe. Cambridge [Cambridgeshire]; New York : Cambridge University Press, 1985.

734 Cli5f $F$ only

CRINOIDEA, FOSSIL--FRANCE--ARMORICAN MASSIF.

Le Menn, Jean. Les Crinoides du dévonien inférieur et moyen de Massif armorician : systématique, paléobiologie, evolution, paléoécologie, biostrátigraphie. Rennes [France] : Société géologique et minéralogique de Bretagne, 1985.

$G(540)$ B $74 \mathrm{~m}$ no 30

CRYSTALLOGRAPHY --ADDRESSES, ESSAYS, LECTURES.

Problemy kristalloknimii i genezisa mineraiov. Leningrad : Nauka, Leningradskoe otd-nie, 1983.

$110 \mathrm{P} 942 \mathrm{k}$

CUBA--GEOLOGY --PERIODICALS.

Revista technólogica. Serie, Geologia. Habana, Cuba : El Ministerio, $1985-$

P (391) M664rg

DATA TRANSMISSION SYSTEMS--PERIODICALS.

Link-up (Minneapolis, Minn.). Link-up. Minneapolis, Minn. : Learned Information, c1983-

$040 \mathrm{fL} 648$

DIAGENESIS .

Almon, W. R. Course notes for the impact of diagenesis on reservoir stimulation and management. [Australia] : Petroleum Exploration society of Australia, [1981]

180 Al68i

DIATOMS--CHINA--COLLECTED WORKS.

The Marine benthic diatoms in China. Beijing : China Ocean Press ; Berlin ; New York : Springer-Verlag, cl985.

$931(610)$ M $338 \mathrm{CE}$

DIATOMS, FOSSIL-- ETHOPIA.

Gasse, Française. Les diatomées lacustres plio-pléistocenes du Gadeb

(Éthiopie) : systématique, paléoécologie, biostratigraphie. paris : Revue algologique, 1980. $697.1(770)$ G2 $15 \mathrm{~d}$

DIJKSTRA, SIJBREN JAN, 1906-1982.

S. J. Dijkstra memorial volume : dedicated to the memory of Sijbren Jan Dijkstra. Haarlem : Geological Survey of The Netherlands, 1983-1984.

(591) qMe n.s. v.37 no.3

DINOFLAGELLATA, FOSSIL-MOROCCO.

Below, Raimond. Cysts of dinoflagellates from the Upper Hauterivian to the Lower Cenomanian of Southwest Horocco $=$ Dinflagellaten-zysten aus dem oberen Huterive bis Unteren Cenoman Sud-West-Marokkos. Ottawa, Ont. i Secretary of State, Multilingual Services Division, Translation Bureau, [1983] 602 (530) qP18E Abt.B Bd.176 Lfg.1-4 
DINOSAURS - - IDAHO.

Dorr, John Adam. Newfound Early Cretaceous dinosaurs and other fossils in southeastern Idaho and westernmost Wyoming Ann Arbor : Museum of Paleontology, The University of Michigan, [1985]

G (255) M58c v.27 no.3

DRAG BITS (DRILLING AND BORING) --TESTING.

Morrell, Roger J. Large-scale laboratory drag cutter experiments in hard rock. Pittsburgh, Pa. : U.S. Bureau of Mines, 1986.

$402(200)$ Un34ex no.9003

DRAINAGE--GERMANY, WEST--SCHLESWIG-HOLSTEIN--WATER-SUPPLY.

Treter, Uwe. Zum Wasserhaushalt Schleswig-Holsteinischer seengebiete.

Berlin : Im Selbstverlag des Institutes fur Physische Geographie der Freien Universitât Berlin, 1981.

$s(530)$ qB52ga Heft 33

DRAINAGE--WISCONSIN .

Henrich, E. W. Drainage area data for Wisconsin streams. [Madison, Wisc.] : U.S. Geological Survey, [1985?]

(200) R290 no.83-933

EARTH--CRUST--ADDRESSES, ESSAYS, LECTURES.

Zemnaia kora i verknniaia mantia Pamira, Gimalaev i IUzhnogo

Tíańshanîa. Moskva : Nauka, 1984.

$312(600)$ Ze42

EARTH--CRUST--BALTIC SEA REGION .

Stroenie zemnoi kory î́go-vostochnoi chasti Baltiliskogo shchita po

geofizicheskim dannym. Leningrad: Nauka, Leningradskoe otd-nie, 1983. $312(576)$ St87

EARTH--CRUST--NEW ZEALAND--NORTH ISLAND.

Stern, T. A. Crustal structure studies within the central North Island :

The Central Volcanic Region. Wellington, N.Z. : Geophysics Division,

Department of Scientific and Industrial Research, 1985.

$P(890)$ qSci2r no.207

EARTH--PHOTOGRAPHS FROM SPACE.

Greetings from earth [videorecording] picture postcards from space. [New York, NY] : Video Vision Associates, cl985.

RB VIDEO- DISC 753.7 G858

EARTH SCIENCE--PERIODICALS .

Earth $\&$ life science editing. Earth $\varepsilon$ life science editing. London : The Association, 1977-1985.

G (500) qEa76 D

EARTH SCIENCES.

Lahiri, Dipankar. The earth alive : its processes and features. New Delni : Allied Publishers Private Lta., 1985. 203.2 Li38e

EARTH SCIENCES--PERIODICALS.

European science editing. European science editing. Bromley, Kent : The Association, 1986-

$G(500)$ qEa76 
EARTH TEMPERATURE--NEW ZEALAND--HELENSVILLE REGION.

Dawson, G. B. Ground temperature surveys at Parakai thermal area, Helensville (1956). Wellington, N.Z. : Geophysics Division, Department of Scientific and industrial Research, 1985.

P (890) qSci2r no. 203

EARTHQUAKE ENGINEERING.

Fluid/structure interaction during seismic excitation : a report. New York, N.Y. : American Society of Civil Engineers, cl984.

240.2 F673 MP

EARTHQUAKE ENGINEERING--CONGRESSES.

Workshop on Strong Ground Motion Simulation and Engineering Applications (1984: Los Altos, Calif.). Strong ground motion simulation and earthquake engineering applications : a technological assessment. Berkeley, Calif. : Earthquake Engineering Research Institute, 1984.

$\mathrm{s}(276)$ P962 no.85-02

EARTHOUAKE HAZARDS ASSESSMENT--CONGRESSES.

U.S.-Japan Workshop on Urban Earthquake Hazards Reduction (1984: Stanford University). Proceedings : U.S.-Japan Workshop on Urban Earthquake Hazards Reduction, held at Stanford University, July 29-August 1, 1984. Berkeley, California : E.E.R.I., [1985]

$S(276)$ P962 no.85-03

EARTHQUAKE HAZARDS ASSESSMENT--PUERTO RICO--CONGRESSES.

Workshop on Reducing Potential Losses from Earthquake Hazards in Puerto Rico (1985: Dorado, Puerto Rico). Proceedings of conference XXX : a Workshop on "Reducing potential losses from earthquake hazards in Puerto Rico", May 30-31, 1985, Dorado, Puerto Rico. Reston, Va. : The Survey, 1985. (200) R290 no.85-731 D MP

EARTHQUAKE HAZARDS ASSESSMENT--UNITED STATES.

National Earthquake Hazards Reduction Program : summaries of technical reports, volume XXI. Menlo Park, Calif. : U.S. Geological Survey, 1985. (200) R290 no.86-31

EARTHQUAKES AND BUILDING--CALIFORNIA--SAN BERNARDINO COUNTY--INSTRUMENTS.

U.S. Geological Survey San Bernardino County Instrumentation Advisory Committee. Report on recommended list of structures for seismic instrumentation in San Bernardino County, California. [Menlo Park, CA] : U.S. Geological Survey, [1986] (200) R290 no.85-583 D MP

EARTHQUAKES--AUSTRIA.

Drimmel, Julius. Die Auswirkung der Friauler Beben in Österreich : makroseismischę Bearbeitung der Starkbeben der Jahhre 1976/1977 samt historischem Ruckblick. Wien : Zentralanstalt fur Meteorologie und Geodynamik, 1979.

$\mathrm{s}(533)$ qAu79a Heft 38

EARTHQUAKES--CATALOGS.

Zirbes, Madeleine. National Earthquake Information Center Waveform catalog : May 1985. [Denver, CO]: U.S. Geological Survey, 1985.

(200) R290 no.85-660E D MP 
Zirbes, Madeleine. National Earthquake Information Center waveform Catalog : June 1985. [Denver, CO] : U.S. Geological Survey, 1985.

(200) R290 no.85-660f D MP

EARTHQUAKES--INFORMATION SERVICES.

Earthquake and tsunami data services and publications. Rev. Boulder, Colo. : National Geophysical Data Center, World Data Center A for Solid Earth Geophysics, 1986.

$P(200)$ NO22 kg no.15 1985

EARTHQUAKES--MAINE--MAPS.

Lepage, Carolyn A. Earthquakes in Maine October 1975 - December 1982. Augusta : Maine Geological Survey, 1983.

M(211) 2419831

Lepage, Carolyn A. Earthquakes in Maine October 1975 - December 1983. Augusta : Maine Geological Survey, 1984.

$M(211) 2419841$

EARTHQUAKES--MEXICO.

Research agenda, learning from the 19 September 1985 Mexico earthquake. [s. 1.] : Nationai Research Council (U.S.), [1986]

$240(300)$ qR312

ECOLOGY--CANADA, NORTHERN--COLLECTED WORKS.

Environmental studies (Canada. Indian and Northern Affairs Canada). Environmental studies. Ottawa : Indian and Northern Affairs Canada, 1978-

$P(100)$ N82e

ECUADOR--GEOLOGY--MAPS.

Ecuador. Dirección General de Geología y Minas. Mapa geológico del

Ecuador : escala 1:100.000. [Quito] : La Direccion, [1973-

$M(465) 2100$

ELECTRIC PROSPECTING--NEW ZEALAND--ROTORUA REGION.

Bennie, S. L. Waterborne resistivity measurements in the Rotorua Lakes area of New Zealand. Wellington, N.Z. : Geophysics Division, Department of Scientific and Industrial Research, 1985.

$P(890)$ qSci2r no.206

ELECTRONIC DATA PROCESSING--CARTOGRAPHY.

Harvara University. Laboratory for Computer Graphics and Spatial Analysis. Lab-log/software. Cambridge, Mass.: The Laboratory.

$035.5 \mathrm{H} 2621 \mathrm{~s}$

ELECTRONIC DATA PROCESSING--SECURITY MEASURES.

Technology assessment : methods for measuring the level of computer security. Gaithersburg, MD: U.S. Dept. of Commerce, National Bureau of Standards; Washington : for sale by Supt. of Doc., U.S. G.P.O., [1985]

$P(200)$ C23mi no.500-133

ENERGY POLICY--OREGON--PERIODICALS.

Oregon. Dept. of Energy. State of Oregon biennial energy plan. Salem, Or.: The Dept., 1985?-

$P(285)$ En $3 \mathrm{~s}$ 
ENGINEERING GEOLOGY--SOVIET UNION.

Bondarik, G. K. Prostranstvennaîa izmenchivost'lednikovykh otlozhenil. Moskva : Nedra, 1985.

$203.3(570)$ B642p

ENGLAND--GEOLOGY--PEAK DISTRICT--GUIDEBOOKS .

Peak District $\&$ northern Dukeries : field guide. Cambridge, Eng. : Quaternary Research Association, 1985. 209.1(510) P313

ENGLISH LANGUAGE--RHETORIC.

Strunk, William. The elements of style. 3d ed. New York : Macmillan, c1979.

053.2 St88e $1979 \mathrm{~F}$ only

ENVIRONMENTAL POLICY--AFRICA, WEST.

Environmental management problems in resource utilization and survey of resources in the west and central African region. Geneva, Switzerland : Regional Seas Programme Activity Centre, United Nations Environment Programme, 1984.

537.5 qun22 no. 37

ENVIRONMENTAL POLICY--CARIBBEAN AREA.

Development and environment in the wider Caribbean region : a synthesis. Geneva, Switzerland : Regional Seas Programme Activity Centre, UNEP, i982. 537.5 qun22 no.14

ENVIRONMENTAL POLICY--MATHEMATICS--CONGRESSES.

Environmental and natural resource mathematics. Providence, R.I. : American Mathematical Society, 1985.

719 Am3ps v.32

ENVIRONMENTAL POLICY--OCEANIA.

Action plan for managing the natural resources and environment of the South Pacific region. Geneva, Switzerland : UNEP, 1983. 537.5 qun22 no.29

ENVIRONMENTAL PROTECTION--AFRICA, EAST.

Environmental problems of the East African region. Geneva, Switzerland : Regional Seas Programme Activity Centre, UNEP, i982.

537.5 qun22 no.12

ENVIRONMENTAL PROTECTION--STATISTICAL METHODS--CONGRESSES.

Environmetrics 81 : selected papers : selections from a conference. Philadelphia : SIAM, 1981.

582 En88e

ETHIOPIA--GEOLOGY--COLLECTED WORKS .

Memoir (Geological Survey of Ethiopia). Memoir. Addis Ababa, Ethiopia : The Survey, $1980-$

(772) M518

ETHIOPIA--MINERAL RESOURCES.

Plate tectonics and metallogenesis : some guidelines to Ethiopian mineral deposits. [Addis, Ababa] : The surveys, [1981]

(772) B no.2 
EUROPE--GEOLOGY--CONGRESSES--ABSTRACTS .

European Geological Societies. Meeting (4th : 1985 : Edinburgh). The evolution of the European lithosphere : abstracts : Edinburgh 9th-12th April 1985, 4th meeting of the European Geological societies : MEGS 4. [Edinburgh, scotland: The Society, 1985] $201(500)$ M472ea 1985

EUTROPHICATION--ADDRESSES, ESSAYS, LECTURES.

Lindmark, Gunilla. Algal assay research in programs for eutrophic lake management : laboratory and field studies. Lund [Sweden] : Institute of Limnology, University of Lund, 1979.

919.55 qL645a 1979

EXPLORERS--SOVIET UNION.

Suziumov, Evgenii Matveevich. Chetvero otvazhnykh : pokorenie severnogo políusa. Moskva : Prosveshchenie, 1981. 502 (995) Su98c MP only

FAULTS (GEOLOGY) --ATLANTIC OCEAN--MADEIRA PLAIN.

Searle, R. C. RRS Discovery, cruise 153, 20 October-17 November 1984 geology and geophysics of the Great Meteor East area, Madeira Abyssal Plain. wormley, Surrey [Eng.] : Institute of Oceanographic sciences, 1985.

$\mathrm{s}(510)$ qIn6er no.172

FAULTS (GEOLOGY) --CALIFORNIA--PARKFIELD REGION--MAPS.

Lienkaemper, James J. Map of faulting accompanying the 1966 Parkfield California, earthquake. [Menlo Park, CA] : U.S. Geological Survey, [1985]

(200) R290 no.85-661 D MP

FAULTS (GEOLOGY) --NEW JERSEY--OLDWICK--MAPS.

Burton, William C. Attitude, movement history, and structure of

cataclastic rocks of the Flemington Fault : results of core drilling near

oldwick, New Jersey. Reston, Va. : U.S. Geological Survey, 1985.

$M(222) 276$ O12b -- M(200) 4 vUn3mf no.1781 -- M(200) MF no.178i

FAULTS (GEOLOGY) --SIKHOTE ALIN (SIBERIA)

Ivanov, Boris Alekseevich. TŚentralfyi Siknoté-Alinskir razlom.

Vladivostok : Dalhevostochnoe knizhnoe izd-vo, 1972.

$276(690)$ IV2t MP oniy

FAULTS (GEOLOGY) --UKRAINE.

Zakonomernosti razviti萑 regionalhoi tektoniki Ukrainy. Kiev : Nauk. dumka, 1983.

$210(571) 214$

FAULTS (GEOLOGY) --UTAH--WASATCH MOUNTAINS.

Schirmer, Tad William. Sequential thrusting beneath the Willard thrust fault, wasatch Mountains, Ogden, Utah. 1985.

MICRO- FICHE $276(273)$ Sch35s D oniy

FINLAND--GEOLOGY .

Nowakowski, Czeslaw. Hydrogeological conditions in the coastal zone of southwestern Finland with respects to the disposal of radioactive waste. Espoo [Finland]: Geologian Tutkimuskeskus, 1984.

(579) qRi no.66 
FINLAND--GEOLOGY--HISTORY.

Virkkala, Kalevi. Geologian tutkimuskeskuksen 100-vuotishistoriikki. [Helsinki]: Geologian tutkimuskeskus, 1986.

$207(587)$ v818g

FLOOD FORECASTING--NORTH CAROLINA--KENANSVILLE REGION .

Stamey, T. C. Frequency and duration of flooding of Grove Creek near Kenansville, North Carolina, for present and proposed restored channel conditions. Raleigh, N.C. : U.S. Geological Survey, 1985.

(200) WRi no.85-4298 D MP

FLOODS--GREAT BRITAIN.

Institution of Civil Engineers (Great Britain). Committee on Floods in the United Kingdom. Flood studies for the United Kingdom. [London?] : The Committee, c1967. $552(510)$ qIn $7 f$

FLOODS--LOUISIANA.

Lee, Fred N. Fioods in Louisiana, magnitude and frequency. 4th ed.

Baton Rouge, La. : Louisiana Dept. of Transportation and Development, 1985. 780 (237) qL93tr no.36

FLOODS--SOUTHERN STATES--MEASUREMENT.

Technical Conference on Small Streams Flood Frequency (1965: Oak Ridge, Tennessee). Proceedings of the Technical Conference on Smali Streams Fiood Frequency : September 23, 24, 1965, Oak Ridge, Tennessee, [Tennessee] : The Division, [1965]

(200) T226p

FLOODS- -TEXAS--AUSTIN--GUIDE-BOOKS.

Urban flooding and slope stability in Austin, Texas. [Austin : Austin Geological Society, 1973 ].

G(245) G938 [no.1]

FLOODS--VIRGIN ISLANDS OF THE UNITED STATES--ST. CROIX--MAPS.

Haire, W. J. Floods of November 11-13, 1974, in St. Croix, U.S. Virgin Islands. San Juan, PR : U.S. Geological Survey, 1978.

$M(394.1) 552 \mathrm{Sa} 2 \mathrm{~h}$

FLORIDA--MAPS, PHYSICAL.

Brooks, H. K. Guide to the physiographic divisions of Florida : Iwith a key to the code symbols on the map 1. Gainesvilie : Florida cooperative Extension Service, [1982]

$508(234)$ B792g 1982 D MP

FLUORESCENCE SPECTROSCOPY.

Eddy, Basil Trewinnard. The determination of molybdenum and tungsten in resin by $x$-ray fluorescence spectrometry. Ranaburg, South Africa : Council for Mineral Technology, [1985]

$s(787)$ qN213r no.M183

FOLDS (GEOLOGY) .

$\dot{E} Z$, V. V. Skiadkoobrazovanie v zemnoí kore. Moskva : Nedra, 1985. 276 Ezl2s

FOLK-LORE OF THE SEA.

Morvan, F. Legends of the sea. New York : Crescent Books, c1980. $090(050)$ M8481 
FORAMINIFERA, FOSSIL--ALASKA.

Pinard, Sylvie. Micropaleontological zonation (Foraminifera, Algae) of the Peratrovich Formation (Lower Cafboniferous, Alaska) = Zonation micropaléontologique (Foraminiferes, Algues) de la Formation de Peratrovich (Carbonifere inférieur, Alaska). [Reston, Va.]: The survey, [1986]

$603.1(286)$ P652zE

FORAMINIFERA, FOSSIL--EUROPE.

Ruget, Christiane. Les foraminifères (Nodosariidés) du Lias de I'Europe occidentale. Lyon : Département des sciences de la terre, Universite Claude-Bernard, 1985.

G (540) qL9d no 94

FORAMINIFERA, FOSSIL--MEDITERRANEAN REGION .

Wonders, Antonius Adrianus Henricus. Middle and late Cretaceous planktonic Foraminifera of the Western Mediterranean area. [1980].

$617(500)$ qW845m

FOUNDATIONS.

Abelev, M. IU. Weak water-saturated clayey soils as foundations for structures $=$ slabye vodonasyshchennye glinistye grunty kak osnovanifa sooruzhenil. [S.I. : S.n.], 1977.

$768.2 \mathrm{Ab} 35 \mathrm{sE}$

FRANCE--MINERAL RESOURCES--PERIODICALS.

Annales des mines. Gerer et comprendre. Annales des mines. Gerer et comprendre / [Ecole nationale supérieure des mines]. Paris : Lécole, $1985-$

$S(540)$ qAn $76 \mathrm{~m}$

FROZEN GROUND--CANADA--CONGRESSES.

Workshop on Permafrost Engineering (1979 : Quebec, Quebec). Proceedings of a workshop on permafrost engineering. Ottawa : National Research Council of Canada, Associate Committee on Geotechnical Research, [1980]

$S(100)$ N21st no.130

FROZEN GROUND--SOVIET UNION.

Danilov, I. D. Metodika kriolitologicheskikh issledovani. Moskva : Nedra, 1983.

256.I (570) D228m

GAMMA RAYS--MEASUREMENT.

Close, D. A. Gamma-ray spectral calculations for uranium borehole logging. Los Alamos, N.M.: Los Alamos Scientific Laboratory, [1980]

815 qun331a no.8417-MS

GAZLI (UZBEK S.S.R.)--EARTHQUAKE, 1976.

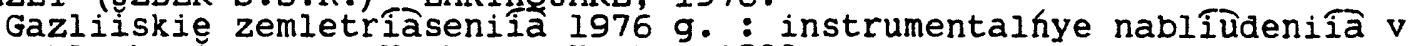
blizhnei zone. Moskva : Nauka, 1983. $240(696)$ G258

GEOCHEMICAL PROSPECTING--CASPIAN DEPRESSION.

Geokhimicheskie osobennosti neftegazonosnosti Prikaspi iskoI vpadiny. Moskva : Nedra, 1985.

$467(570)$ M845t vyp.251 
GEOCHEMICAL PROSPECTING--COLORADO--BUFFALO PEAKS REGION--MAPS.

Nowlan, G. A. Maps showing water geochemistry of the Buffaio Peaks Wilderness Study Area, Lake, Park, and Chaffee Counties, Colorado. Reston, Va. : U.S. Geological Survey, 1985.

M (271) 426.2 B864n -- M(200) 4 vUn3mf no.1628-E -- M(200) MF no.1628-E

GEOCHEMICAL PROSPECTING--COLORADO--CLEAR CREEK COUNTY--MAPS.

Barton, H. N. Geochemical maps showing the distribution and abundance of selected elements in heavy-mineral concentrates of stream sediments from the Vasquez Peak Wilderness Study Area and the Williams Fork and St. Louis Peak Roadless Areas, Clear Creek, Grand, and Summit Counties, Coloradd. Reston, Va.: U.S. Geological Survey, 1985.

$M(271) 426.2$ V444b -- M (200) 4 vUn3mf no.1588-G -- M(200) MF no.1588-G

GEOCHEMICAL PROSPECTING--COLORADO--EAGLE COUNTY.

Detra, D. E. Analytical results and sample locality map of stream-sediment, heavy-mineral-concentrate, and rock samples from the Bull Gulch Wilderness Study area (CO-070-430), Eagle County, Colorado. [Denver, CO] : U.S. Geological Survey, 1985.

(200) R290 no.85-674 D MP

GEOCHEMICAL PROSPECTING--COLORADO--GRAND COUNTY--MAPS .

Barton, H. N. Geochemical maps showing the distribution and abundance of selected elements in heavy-mineral concentrates derived from stream sediments and ridgetop soils from the Upper Keyser Creek Basin in the St. Louis Peak Roadless Area, Grand County, Colorado. Reston, Va. : U.S. Geological Survey, 1985.

M (271) 426.2 K523b - M (200) 4 vUn $3 m f$ no.1588-H -- M(200) MF no.1588-H

GEOCHEMICAL PROSPECTING--CONGRESSES,

Mezhdunarodnyi simpozium "Metody prikladnoi geokhimii" (2nd : 1981 : Irkutsk, R.S.E.S.R.). Geoknimicheskie metody poiskov i otsenki rudnykh mestorozhdenii : materialy vtorogo mezhdunarodnogo simpoziuma "Metody prikladnoi geoknimii". Novosibirsk : Izd-vo Nauka, Sibirskoe otd-nie, 1985.

426.2 M $578 \mathrm{gmp}$

GEOCHEMICAL PROSPECTING--MAINE--AROOSTOOK COUNTY--MAPS.

North American Exploration, Inc. Evaluation of the mineral potential, Upper St. John River Valley, Aroostook County, Maine : Appendix B:

Geochemistry. Augusta : Maine Geological Survey, 1980.

$M(211) 426.2$ Up6n

GEOCHEMICAL PROSPECTING--MISSOURI--SPRINGFIELD QUADRANGLE--MAPS .

Summary geochemical and generalized geologic maps of the Springfield lipo isx 2, po isquadrangle and adjacent area, Missouri. Reston, Va.: U.S. Geological Survey, 1985.

M (263) 426.2 Sp84e -- M (200) 4 vUn3mf no.1830-A -- M(200) MF no.1830-A

GEOCHEMICAL PROSPECTING--SAUDI ARABIA--MAHD AD DHAHAB REGION.

Geochemistry and preliminary assessment of resource potential for postorogenic granites of the east-central Arabian Shield, Kingdom of Saudi

Arabia. [Reston, VA] : U.S. Geological Survey, [1986]

(200) R290 no.86-104 D MP

GEOCHEMICAL PROSPECTING--SOVIET UNION.

Geoknimicheskie metody pri poiskakh rudnykh mestorozhdenir. Moskva : Nedra, 1982 .

$426.2(570)$ G29 $2 \mathrm{mpp}$ 
GEOCHEMICAL PROSPECTING--SOVIET UNION--ADDRESSES, ESSAYS, LECTURES.

Geochemical methods of prospecting for deep-seated ore deposits = Geokhimicheskie metody poiskov glubokozalegaîushchikh rudnykh mestorozhdenii. [Reston, Va.] : The Survey, [1984]

$426.2(570)$ G292mpgE

GEOCHEMICAL PROSPECTING--TRANSBAIKALIA.

Pogrebniâk, IU. F. Gidrogeoknimicheskie poiski rudnykh mestorozhdeni $v$ Zabaikalé. Novosibirsk : Nauka, Sibirskoe otd-nie, 1985.

$426.2(690.3)$ P753g

GEOCHEMICAL PROSPECTING--UZBEKISTAN

Sirazhidinov, Dalavai. Geokhimiî̀ uglevodorodnykh flîuidov mezokainozoiskikh otlozhenii Uzbekistana. Tashkent : Izd-vo Fan Uzbekskoi SSR, 1982 .

426.2 (696) Si76g

GEOCHEMICAL PROSPECTING--VERMONT--BENNINGTON COUNTY--MAPS.

Ayuso, Robert A. Geochemical survey of the Lye Brook Wilderness, Bennington and Windham Counties, Vermont. Reston, VA: U.S. Geological Survey, 1985.

M (213) 426.2 L986a -- M (200) 4 vUn3mf no.1609-B -- M(200) MF no.1609-B

GEOCHEMISTRY--CALIFORNIA--SAN DIEGO COUNTY.

Detra, D. E. Analytical results and sample locality map of heavy-mineralconcentrate samples from the Sawtooth Mountains Wilderness Study area (CA060-024B), San Diego County, California. [Denver, CO]: U.S. Geological Survey, 1985.

(200) R29o no.85-748 D MP

GEOCHEMISTRY--COLORADO--JEFFERSON COUNTY .

Young, Edward J. Summary of the geology, economic aspects, and geochemistry of the Schwartzwalder uranium-bearing area, Ralston Buttes district, Jefferson County, Colorado. Washington, D.C.' U.S. G.P.O., 1985 .

(200) E no.1555 D MP

GEOCHEMISTRY --CONGRESSES .

Geomedical research in relation to geochemical registrations. Oslo : Universitetsforlaget, cl984.

$298(581)$ G292

GEOCHEMISTRY--GERMANY, WEST--MAPS

Geochemischer Atlas Bundesrepubiik Deutschland : Verteilung von

Schhwermetallen in Wassern und Bachsedimenten. Hannover : Bundesanstalt

fur Geowissenschaften und Ronstoffe; In Kommission E. Schweizerbartsche Verlagsbuchhandlung (Nägele u. Obermiller), 1985.

$308(530)$ ffG292

GEOCHEMISTRY - KERALA.

Nair, A. M. Petrochemistry of the crystalline rocks and morphology of zircons from Manimala River valley in Kottayam and Alleppey Districts, Kerala. Trivandrum, India : Centre for Earth Science Studies, 1984. $G(640)$ fT226 no.36

GEOCHEMISTRY - PENNSYLVANIA.

Ficklin, Walter $\mathrm{H}$. Analytical results for 186 water samples collected in Berks, Bucks, Chester, Lancaster, and Montgomery Counties, Pennsylvania. [Denver, CO]': U.S. Geological Survey, 1985.

(200) R290 no.85-667 D MP 
GEOCHEMISTRY--TRANSLATIONS FROM RUSSIAN--PERIODICALS.

Geochemistry (Ann Arbor, Mich.). Geochemistry. Ann Arbor, Mich. : The Society, 1956-1963.

G(570) G29e

GEODESY--COLLECTED WORKS.

Karlsruher geowissenschaftliche Schriften. Reihe B, Geodätische, photogrammetrische und kartographische Berichte. Karlsruhe :

Fachnochschule Karlsruhe, Fachbereich Vermessungswesen und Kartographie, 1985-

$\mathrm{S}(530) \mathrm{K} 146 \mathrm{~g}$

GEODESY--PERIODICALS.

Australian journal of geodesy, photogrammetry, and surveying. Australian journal of geodesy, photogrammetry, and surveying. Kensington : The School, 1979-

$\mathrm{S}(800)$ Au78gp

GEODESY--UNITED STATES.

Brittain, John Holman. Geodetic operations in the United States and in other areas through international cooperation, January 1, 1957 to December

31, 1959 : report to the International Association of Geodesy of the International Union of Geodesy and Geophysics, International Council of Scientific Unions. Washington, U. S. Govt. Print. Off., 1960.

$P(200)$ Cl4go no.60-2

GEOGRAPHY --COLLECTED WORKS.

Erdkundliches Wissen. Erdkundliches Wissen. Stuttgart : Franz Steiner Verlag Wiesbaden GMBH, 1952-

$S(530)$ G33a

GEOGRAPHY - POLAND--PERIODICALS.

Geographia studia et dissertationes. Katowice : Uniwersytet Slaski.

$S(578)$ G2925

GEOLOGIC MAPPING--COMPUTER PROGRAMS.

Selner, Gary I. GSDRAW and GSMAP : prototype programs for the IBM PC or compatible microcomputers to assist compilation and publication of geologic maps and illustrations. Denver, Colo.: U.S. Geological Survey, 1986.

(200) R290 no.86-42 D MP

GEOLOGICAL MAPPING--CONGRESSES.

International Symposium on Remote Sensing of Environment : Thematic Conference (3rd : 1984 : Colorado Springs).Proceedings of the International Symposium on Remote Sensing of Environment, Third Thematic Conference: "Remote sensing for exploration geology", 16-19 April 1984 . Ann Arbor, Mich., : Environmental Research Institute of Michigan, 1984.

753.7 In83p 1984

International Symposium on Remote Sensing of Environment : Thematic Conference (4th : 1985 : San Francisco, California). Proceedings of the International Symposium on Remote Sensing of Environment, Fourth Thematic Conference : 11 Remote sensing for exploration geology", 1-4 April 1985. Ann Arbor, Mich., : Environmental Research Institute of Michigan, 1985.

753.7 In83p 1985 
International Symposium on Remote Sensing of Environment : Thematic Conference (2nd : 1982 : Fort worth, Texas.). Proceedings of the International Symposium on Remote Sensing of Environment, Second Thematic conference : " Remote sensing for exploration geology", December 6-10, 1982. Ann Arbor, Mich., : Environmental Research Institute of Michigan, 1983.

753.7 Iń33p 1982

GEOLOGICAL MAPPING--SWITZERLAND.

Fischer, Hermann. Geologische Karten, eine Landesaufgabe : 125 Jahre Schweizerische Geologische Kommission, organ der Schweizeriwchen Naturforschenden Geselischaft = Les carte géologiques, une tâche nationale : 125e anniversaire de la Commission géologique suisse, organe de la Société helvétique des sciences naturelles [Texte und Bildauswanl, Hermann Fischer, Heinrich Jackli, Walter Nabholz]. Basel : Die Kommission, 1985 . (535) G293 1985

GEOLOGICAL RESEARCH--ONTARIO.

Exploration Technology Development Program of the Board of Industrial Leadership and Development : summary of research, 1984-1985. Toronto : Ontario Ministry of Natural Resources, 1985.

402 (150) qon82mp no.125

GEOLOGICAL SURVEY (U.S.) . WATER RESOURCES DIVISION.

Holmes, Sandra L. History of Water Resources activities of the U.S. Geological Survey : water fact sheet. Reston, Va. : U.S. Geological Survey, [1985]

(200) R290 no.85-646 D MP

GEOLOGICAL TIME--CALIFORNIA--SAN PABLO BAY REGION--MAPS .

Potassium-argon and fission-track ages of the Sonoma volcanics in an area north of San Pablo Bay, California. Reston, Va. : U.S. Geological Survey, 1985.

M(276) 315 Sa53f -- M(200) 4 vUn3mf no.1753 -- M(200) MF no.1753

GEOLOGICAL TIME--GERMANY, WEST--STCHIEFERGEBIRGE.

Reuter, Antje. Korngróssenabhängigkeit von $\mathrm{K}-\mathrm{Ar}$ Datierungen und IllitKristallinität anchizonaler Metapelite und assoziierter Metatuffe aus dem ostlichen Rheinischen Schiefergebirge. Gottingen..: Im Selbstverlag der Geologischen Institute der Georg-August-Universität, 1985. G(530) G715 Nr.27

GEOLOGY--COLLECTED WORKS.

CESEN report (Centro studi energia Renzo Tasselli). CESEN report. Genova : Il Centro.

$\mathrm{G}(550)$ qC333

GEOLOGY--DATA PROCESSING--CATALOGS.

Geology programs for microcomputers. 4 th ed. Denver : Computer oriented Geological Society, cl985.

037.2 G293

GEOLOGY, ECONOMIC--ARKANSAS.

Arkansas-Texas economic geology field trip, February 23 and $24,1974$. Reprinted 1975. Little Rock, Ark. : Arkansas Geological Commission, 1975. (241) Ar78g [no.74-1] 
GEOLOGY --INFORMATION SERVICES.

Smirnova, A. S. Informatsionny i analiz v geologii. Moskva : Nedra, 1985.

$040 \mathrm{Sm} 481$

GEOLOGY--MATHEMATICS--COLLECTED WORKS .

Mathematical geology. New York : Pienum, cl986-

209 In $8 j$

GEOLOGY--POPULAR WORKS.

Balandin, Rudolf Konstantinovich. Kamennaía letopis'Zemli. Moskva : Izd-vo "Znanie", 1983.

204 Bl82k

GEOLOGY, STRATIGRAPHIC.

Fanerozoí Sibiri. Novosibirsk : Nauka, Sibirskoe otd-nie, 1984.

G(690) Akl6t vyp.595-6

Haley, Boyd Raymond. A guidebook to the second geological excursion on Lake Ouachita. Little Rock, Ark. : State of Arkansas, Arkansas Geological

Commission, 1979.

(241) Ar7g $[$ no. $79-4]$

Metodika paleogeomorfologicheskikh issledovaniI neftegazonosnykh oblasteĭ SSSR. Moskva : Nedra, 1985.

$467(570)$ M845t vyp. 250

GEOLOGY, STRATIGRAPHIC--ADDRESSES, ESSAYS, LECTURES .

AAPG stratigraphic interpretation of seismic data, November 28 - December 3 , 1983, Colorado Springs, Colorado. [Tulsa, Okla.?] : The Association, c1983.

$240.1(200)$ qAm3as

GEOLOGY, STRATIGRAPH IC--ARCHEAN .

Kozyreva, Irina vitấévna. Giubinny metamorfizm pozanearkheisskikh vulkanogennykh poíasov. Moskva : Nauka, 1985.

$320(690.3)$ K8489

GEOLOGY, STRATIGRAPHIC--CHARTS, DIAGRAMS, ETC.

American Association of Petroleum Geologists. Correlation of stratigraphic units in North America. Tulsa, Okla. : American Association of Petroleum Geologists, 1983-

M (200) $3051983 a$

GEOLOGY, STRATIGRAPHIC--COLLECTED WORKS .

Travaux du Laboratoire de stratigraphie et de paleoecologie. Travaux du Laboratoire de stratigraphie et de paleoecologie. Marseille : Le Centre, $1983-$

$G(540)$ qT698r

GEOLOGY, STRATIGRAPHIC--CRETACEOUS.

Dyman, Thaddeus S. Preliminary stratigraphic correlation of the Cretaceous Blackleaf and lower Frontier Formations in Beaverhead and Madison counties, Montana. [Denver, Colo.] : U.S. Geological Survey, 1985.

(200) R290 no.85-729 D MP 
Voigt, Enrhard. Wann haben sich die Feuersteine der Oberen Kreide gebildet? Gottingen : Vandenhoeck \& Ruprecht, 1979.

$\mathrm{S}(530) \mathrm{G} 72$ Ser.2 Janrg.1979 Nr.6

GEOLOGY, STRATIGRAPHIC--DEVONIAN

Kochmann, Gunther. Die oberdevonische bis unterkarbonische Schichtenfolge und der Schuppenbau im NW-Bereich des mittleren Acker-Bruchberg-Zuges (Oberharz) $[1968 \mid$

$335(530)$ K8130

GEOLOGY, STRATIGRAPHIC--JURASSIC.

Palacios M., Carlos. The Jurassic paleovolcanism in Northern Chile. IS. 1 i. s.n. 1978 .

$342(4 \dot{3} 0)$ Pi $2 j$

GEOLOGY, STRATIGRAPHIC--MISSISSIPPIAN--ABSTRACTS.

European dinantian environments : abstracts : first meeting - Manchester, April 11-13 1984. [Milton Keynes] : Department of Earth Sciences, the Open University, [1984]

$336(500)$ Eu $74 a$

GEOLOGY STRATIGRAPHIC--ORDOVICIAN .

Graniťsa ordovika i silura na severo-Vostoke SSSR. Leningrad : Nauka, Leningradskoe otd-nie, 1983.

(570) T765msk t.II

A Guidebook to the Ordovician-Mississippian rocks of north-central Arkansas. [Little Rock, Ark.] : State of Arkansas, Arkansas Geological Commission, [1979]

(241) Ar7g no.79-1

GEOLOGY, STRATIGRAPHIC--PALEOZOIC.

Craig, William W. A guidebook to the Post-st. Peter Ordovician and the Silurian and Devonian rocks of north-central Arkansas. Little Rock, Ark. : Arkansas Geological Commission, [1984]

(241) Ar7g no.84-1

Zhivkovich, A. E. Paleozoĭskie formaEsii i tektonika Ufimskogo amfiteatra. Moskva : Nauka, 1985.

$330(570) \mathrm{z} 62 \mathrm{p}$

GEOLOGY, STRATIGRAPHIC--PALEOZOIC--ADDRESSES, ESSAYS, LECTURES.

paleozoí Severa Urala i Pechorskoí sineklizy. Syktyvkar : Komi filial AN SSSR 1984.

$G(570)$ Ak144t vyp. 49

GEOLOGY, STRATIGRAPHIC--PERMIAN .

Koroliuk, I. K. Metody i rezultaty izucheni帒 permskogo rifogennogo

massiva Shakhtau : Bashkirskoe Priuralé. Moskva : Nauka, 1985.

$337(570) \mathrm{K} 843 \mathrm{~m}$

GEOLOGY, STRATIGRAPHIC--PERMIAN--MAPS.

Kume, Jack. Depth and thickness of selected units in Upper Permian, Upper Jurassic, and Lower Cretaceous rocks in southwestern Kansas. [Lawrence, Kansas] : U.S. Geological Survey, 1983.

M (267) 3 So88k 
GEOLOGY, STRATIGRAPHIC--PLEISTOCENE.

Baker, Robert W. Pleistocene history of west-central Wisconsin : discussion, roadiog, and geologic stop descriptions. Madison, Wis. : Wisconsin Geological and Natural History Survey, 1984.

(254) F458 no.11

Goldyrev, Gennadil Stepanovich. Osadkoobrazovanie i chetvertichna垈 istoriia kotloviny Baikala. Novosibirsk: Nauka, Sibirskoe otd-nie, 1982 .

$353(690.3) \quad 65780$

Sinn, Peter. Zur..Stratigraphie und Paläogeographie des Präwürm im mittleren und sudilchen Illergletscher-Vorfand. Heidelberg, selbstverlag des Geographischen Instituts der Universitat, 1972.

$S(530)$ H $454 \mathrm{~b}$ no. 37

GEOLOGY, STRATIGRAPHIC--PRE-CAMBRIAN .

Blacet, Philip M. Proterozoic geology of the Brady Butte area, Yavapai County, Arizona : a study of the stratigraphy and structure of the Proterozoic stratified and associated intrusive rocks. Washington : U.S. G.P.O., 1984 .

(200) E no.1548 D MP

Blick, Nicholas Hammond. Stratigraphic, structural and paleogeographic interpretation of upper Proterozoic glaciogenic rocks in the sevier orogenic Belt, northwestern utah. 1979.

$681(273)$ B618s MP only

Brangulis, A. P. Vend i kembrĭ Latvii : stratigrafiîa, litologi ià i kollektorskie svoistva. Riga: Zinatne, 1985 .

$320(574)$ B $734 \mathrm{~V} \mathrm{D}$

GEOLOGY, STRATIGRAPHIC--PRE-CAMBRIAN--ADDRESSES, ESSAYS, LECTURES .

stratigrafi îa i litologi ia dokembriiskikh i rannepaleozoiskikh otlozhenii Urala. Sverdlovsk : UNTS AN SSSR, 1982.

$320(570)$ St82

GEOLOGY, STRATIGRAPHIC--QUATERNARY .

Mangerud, Jan. Quaternary stratigraphical studies in Hordaland, Western Norway. Bergen : Universitetet $i$ Bergan, Geologisk institutt, Ava. B., 1972 .

$352(58 i)$ M3I4f

GEOLOGY, STRATIGRAPHIC--QUATERNARY--ADDRESSES, ESSAYS, LECTURES .

TER-QUA Symposium series (Nebraska Academy of Sciences. Institute for Tertiary-quaternary stuaies). TER-QUA Symposium series. Lincoln, Neb.: The Academy, 1985-

$G(266)$ N278t

GEOLOGY, STRUCTURAL .

IUshmanov, Vladimir vladimirovich. Tektono-magmaticheskie kontsentricheskie kompleksy : teoreticheskie, metodicheskie i prakticheskie voprosy izucheniia. Moskva : Nauka, 1985. $210(690.3)$ Iu 7 t

Paleotektonika Belorussii. Minsk : Nauka i teknnika, 1983. $210(577)$ PI74 
GEOLOGY, STRUCTURAL--ADDRESSES, ESSAYS, LECTURES .

Tektonika i neftegazonosnost kontinentalfykh okrain : sbornik nauchnykh trudov. Leningrad : VNIGRI, 1983. $203(050)$ T235

Tektonika molodykh platform. Moskva : Nauka, 1984. $210(690.2) \mathrm{T} 235 \mathrm{~m}$

GEOLOGY, STRUCTURAL--CONGRESSES.

International Conference on Basement Tectonics (6th: 1985 : Santa Fe, New Mexico). Abstracts with program : 6 th International Conference on Basement Tectonics, September 16-20, 1985, Sweeney Center, Santa Fe, New Mexico, USA. Salt Lake City, Utan: International Basement Tectonics Association, 1985.

210 In8pa 1985

International Symposium Strucțure and Dynamics of Transition Zones (1983: Sochi, R.S.F.S.R.L Mezhdunarodnyi simpozium stroenie i dinamika perekhodnykn zon : k 100-letîù mezhdunarodnoi planetarnoi geofiziki, Sochi, 7-14 dekabria $1983 \mathrm{~g}$. : tezisy dokladov. Moskva : Mezhduvedomstvennyi geofizicheskii kom-t pri Prezidiume Akademii nauk SSSR, 1983.

210 In $8 \mathrm{~m}$

GEOLOGY, STRUCTURAL--MAPS.

Feltis, R. D. Map showing configuration of the top of the Madison Group, Choteau 1-degree by 2-degree quadrangle, Montana. [Butte, Mont.] : Montana Bureau of Mines and Geology, 1984.

$M(281) 21$ C $457 f$

Griffin, John R. Geology of the north-central portion of the Bangor $2+$ po isquadrangle and the south-central portion of the Millinocket 2 ipo isquadrangle, Maine. Augusta : Maine Geological survey, 1976.

$M(211) 21 \quad B 225 \mathrm{~g}$

Hussey, Arthur M. Preliminary bedrock and brittle fracture map of the Portiand 2 pois quadrangle. [Augusta]: Maine Geological Survey, 1978. $M(211) 21$ P837h

Pankiwskyj, Kost A. Preliminary geologic map of the Maine part of the Lewiston 21 pois quadrangle. Augusta, Me.: Maine Geological survey, 1980. $M(211) 21$ L $588 p$

GEOMORPHOLOGY --CONGRESSES .

Global mega-geomorphology: proceedings of a workshop sponsored by the National Aeronautics and space Administration and the International Union of Geological Sciences and held at Sunspace Ranch, oracle, Arizona, January 14-16, 1985. Washington, D.C. : NASA, Scientific and Technical Information Branch, 1985 .

$P(200)$ NA35Cp no.2312

GEOMORPHOLOGY--GERMANY, WEST.

Semmel, Arno. Geomorphologie der Bundẹsrepublik Deutsçnland : Grundzüge, Forschungsstand, aktuelle Fragen--erortert an ausgewahlten Landschaften. 4., vollig uberarb. u. erw. Aufl. Stuttgart : F. Steiner Verlag Wiésbaden, 1984.

S (530) G33a Heft 301984 
GEOMORPHOLOGY--KERALA.

Morphology and land use of the Mitraniketan Campus : a microlevel study. Trivandrum, India : Centre for Earth Science Studies, 1984 .

$G(640)$ fT226 no.41

GEOMORPHOLOGY--TECHNIQUE.

Shorter technical methods (v). Norwich : Geo Abstracts, cl984.

$S(520)$ B 777 t no.33

GEOPHYSICS--DATA PROCESSING--PERIODICALS.

Advances in geophysical data processing. Advances in geophysical data processing. Greenwich, Conn. : JAI Press, cl984-

$S(200)$ Ad95g

GEORGIA--GEOLOGY--CHARTS, DIAGRAMS, ETC.

Geologic section of the updip coastal plain from Central Georgia to Western South Carolina. Reston, va.: U.S. Geological Survey, 1985.

$M(233) 305$ C333p - M (200) 4 vUn 3mf no.1737 - M(200) MF no.1737

GEORGIA--MINERAL RESOURCES--LUMPKIN COUNTY.

Wood Robert $H$. Mineral investigation of the Board Camp and Raven Cliff RARE II Study Areas, Lumpkin, Union, and White Counties, Georgia.

[washington, D.C. ! : United States Department of the Interior, Bureau of Mines, 1986.

$402(200)$ Un34msi no.7-86

GEOSYNCLINES--BELGIUM .

Michot, $P$. Le segment tectogénique calédonien belge. Bruxelles :

Palais des Academies, 1980.

$S(593)$ Ac23 ser. 2 t. 43 fasc. 6

GEOTHERMAL ENGINEERING.

Hot dry rock geothermal energy development program : annual report, fiscal year 1980. Los Alamos, N.M. : Los Alamos National Laboratory ;

Springfield, Va.: Available from N.T.I.S., [1981]

815 qun33la no.8855-HDR

GEOTHERMAL RESOURCES--NEW MEXICO.

Evaluation of geothermal potential of the Basin and Range province of New Mexico. Las Cruces : New Mexico Energy Institute at New Mexico state University, 1976.

S (272) N418n no.6

GERMANY, EAST--GEOLOGY--GUIDEBOOKS.

Sedimentary and tectonic structures in the saxothuringian and Rhenohercynian zones: guidebook of excursions in the German Democratic Republic, September 1984 Potsdam [E. Germany] : The Institute, 1984.

$209.1(531) \mathrm{Se28}$

GERMANY --GEOLOGY--RHINELAND--ADDRESSES, ESSAYS, LECTURES

Beiträge zum Quartar der nördlichen Rheinlande. Bonn [West Germany] :

In Kommission bei Ferd. Dummlers verlag, 1983.

$S(530)$ qB643 Heft 51

GERMANY, WEST--GEOLOGY--EIFEL REGION .

Bahrig, B. Sedimentation und Diagenese im Laacher seebecken (o'steife). Bochum : Institut fur Geologie der Runr-Universitä-Bochum, [1985]

$G(530)$ qBб 28 Heft 19 
GLACIAL EPOCH--ALASKA--CONGRESSES.

Glaciation in Alaska : the geologic record. Anchorage, AK : Alaska Geological society, cl986.

$250(286)$ G451

GLACIERS--CAUCASUS.

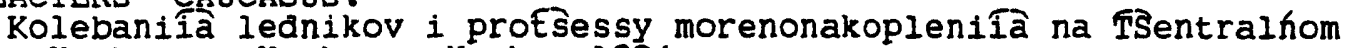
Kavkaze. Moskva : Nauka, 1984.

$250(570) \mathrm{K} 832$

GOLD MINES AND MINING--YUKON TERRITORY--HISTORY.

Gilbert, George W. A brief history of placer mining in the yukon.

Whitehorse : Indian and Northern Affairs Canada: [Available from] Minister of Supply and Services Canada, 1983. $403(182)$ In $39 \mathrm{~b}$

GOLD ORES--SOUTH AFRICA.

The Recovery of pyrite and gold from acid-leach residues from the Merriespruit Gold Mine. Randburg, S.A. : Council for Mineral Technology, 1984 .

$\mathrm{S}(787)$ qN213r no.MI8D 1984

GOLD ORES - -VENEZUELA.

López, Víctor M. Ėl oro. Venezuela : Ministerio de Energia y Minas, [1981]

$431 \mathrm{~L} 8820$

GRANITE.

DubrovskiǏ, M. I. Granitnye sistemy i granity. Leningrad : Nauka, Leningradskoe otd-nie, 1984.

$170(570)$ D854g

GRANITE--MONGOLIA.

Zanvilevich. A. N. Mongolo-Zabaikalskaîa shchelochnogranitoianaîa provintsiia : geologiia i petrologiia. Moskva : Nauka, 1985.

$170(600) \mathrm{ZI} 7 \mathrm{~m}$

GRANITE--SOVIET UNION

Liakhovich, Valerii vladimirovich. Faktory rudogeneriruîushchei sposobnosti granitoidov. Moskva : Nauka, 1983.

$170(570) \mathrm{L} 613 \mathrm{f}$

GRANITE--TESTING.

Savage, David. The geochemical interactions of simulated borosilicate waste glass, granite and water at 100-350,p0 ISC and 50MPa. Keyworth, England: British Geological Survey, 1984 .

(510) qR298 FLPU no.84-3

GRAPHIC METHODS.

Bertin, Jacques. Semiology of graphics : diagrams networks maps. Madison, Wis. : University of Wisconsin Press, 1983.

067 B462sE F only

GRAVITY ANOMALIES--NORTH SEA--MAPS.

Tully, M. C. I:I 000 000 northern North Sea Bouguer anomaly gravity map. London : Her Majesty's stationery office, 1985.

(510) qR2 v.16 no.6 
GRAVITY--NEW ZEALAND--TAUPO REGION .

Hunt, T. M. Repeat gravity measurements at Wairakei geothermal field, 196l1983 : data and measurement techniques. Wellington, N.Z. : Geophysics Division, Department of Scientific and Industrial Research, 1984. $P(890)$ qsci2r no.201

GRAVITY STATIONS--CALIFORNIA.

Roberts, Carter $W$. High-precision gravity stations for monitoring vertical crustal motion in southern California. [Menlo Park, Calif.] : U.S. Geological Survey, 1986.

(200) R290 no.86-44'D MP

GRAVITY STATIONS--MAINE--PENOBSCOT VALLEY--MAPS .

Fisher, Lawrence T. Gravity survey of the Northern Penobscot Valley area, Maine. Augusta : Maine Geological Survey, 1983.

$M(211) 297.5$ P386f

GROUNDWATER FLOW--DATA PROCESSING.

Madsen, Bjarne. Interactive computer processing and interpretation of pumping test data : a micro-computer program using dynamic graphics. [Copenhagen] : Geological Survey of Denmark, Ministry of the Environment, [1985]

(585) qG8sc no.4

GROUNDWATER FLOW--IDAHO--DATA PROCESSING.

Garabedian, Stephen P. Application of a parameter-estimation technique to modeling the regional aquifer underlying the eastern Snake River Plain, Idaho. Boise, Idaho: U.S. Geological Survey, 1985.

(200) R29o no.84-46I

GROUNDWATER FLOW--JAPAN--CHIBA.

Kondon, Akiniko. Study on the groundwater flow system by environmental tritium in Ichinara region, chiba prefecture. Ibaraki, Japan : The University of Tsukuba Environmental Research Center, 1985. $S(620)$ Eng2 no.6

GROUNDWATER FLOW--MATHEMATICAL MODELS.

Brightman, $M$. A. Finite element modelling of the Harwell regional groundwater flow regime. Keyworth, England : British Geological survey, 1984.

(5I0) qR298 FLPU no.84-1

Cooley, Richard L. Regression modeling of ground-water flow. Lakewood, Colo.: U.S. Geological Survey, 1985.

(200) R290 no.85-180

Dzhanybekov, Ch. Metody filtrafsionnykh raschetov $v$ sloistykh sredakh. Frunze : Ilim, 1983. 490 D996mf

HAITI.

Haiti, a country study. Washington, D.C. : for sale by the Supt. of Docs., U.S. Govt. Print. Off., cl982.

504 (393) Am35a 1982

HANDTC (COMPUTER PROGRAM) .

Spielman, J. B. HandtC : a FORTRAN program to calculate inner-zone terrain corrections. Menlo Park, Calif. : U.S. Geological Survey, 1984.

(200) R290 no.84-777 D MP 
HAZARDOUS WASTE SITES--OCEANIA.

Hazardous waste storage and disposal in the South Pacific. Geneva,

Switzerland : Regional Seas Programme Activity Centre, UNEP, 1984. 537.5 qun 22 no. 48

HAZARDOUS WASTES--UNITED STATES.

Report to Congress : wastes from the extraction and beneficiation of metallic ores, phosphate rock, asbestos, overburden from uranium mining, and oil shale. Washington, D.C. : The office, [1985] $P(200)$ En85srw

HEAVY MINERALS--ADDRESSES, ESSAYS, LECTURES .

Economic analysis of heavy minerals in sediments. New York, N.Y. : Van Nostrand Reinhold, cl985.

209 B 432 v. 86

HIGHLAND SILVER LAKE, ILL.

Davenport, Thomas E. Water resource data and preliminary trend analysis for the Highland Silver Lake monitoring and evaluation project : Madison County, Illinois, phase III. Springfield, Ill. : Planning section, Division of Water Pollution Control. Illinois Environmental Protection Agency, [1984].

$797(253)$ D277W Phase III

HORSES, FOSSIL.

Eisenmann, Véra. Etude des dents jugales inférieures des Equus

(Mammalia, Perissodactyla) actuels et fossiles. Montpeliier : Laboratoire de paléontologie des vertébrés de l'Ecole pratique des nautes études : Laboratoire de paléontologie de l'Université des sciences et techniques du Languedoc, [1981]

$602(540)$ PI 72 v.10 fasc.3-4

HYDRATES.

Groisman, Aleksandr Genrikhovich. Teplofizicheskie svoǐstva gazovykh gidratov. Novosibirsk : Izd-vo Nauka, Sibirskoe otd-nie, 1985. $467.4(690) \mathrm{G} 894 \mathrm{t}$

HYDRAULIC ENGINEERING--JORDAN RIVER VALLEY, JORDAN .

Yarmouk-Jordan Valley project : master plan report. [Rochester, Pa.] 1955. $778(685)$ qY22

HYDROLOGICAL FORECASTING--CONGRESSES.

Real-time data collection systems and hydrological forecasting : proceedings of the technical conference. Geneva : Secretariat of the World Meteorological Organization, 1984.

780.01 qR228

HYDROLOGY--CALIFORNIA--PERIODICALS.

California high water. California high water. [Sacramento, Calif.] : The Dept.

$P(276)$ En26 no.69-65+

HYDROLOGY--GERMANY, WEST--RESEARCH .

Nationalkomitee der Bundesrepublik Deutschland für das Internationale Hydrologische Programm. Internationales hydrologisches Programm : Beitrag Bundesrepublik Deutschiand 1975-1977 = International Hydrological Programme : contribution, Federal Republic of Germany, 1975-1977. Koblenz : Die Nationalkomitee, 1977.

$780(530)$ qN213i D 
HYDROLOGY --NEW MEXICO--PERIODICALS.

Geological Survey (U.S.). Water Resources Division. Annual report to the Pecos River Commission on investigations being made in New Mexico and Texas by the United States Geological Survey in cooperation with the Pecos River Commission. [S. I.] : The Division.

(200) WR3arp

HYDROLOGY--SOVIET UNION--CONGRESSES.

Voprosy gidrologii sushi : doklady konferentsii molodykh uchenykh i spetsialistov, Leningrad, GGI, fevral'1981 g. Leningrad : Gidrometeoizdat, 1982 .

$780(570)$ v898gs

HYDROLOGY--TEXAS--AUSTIN REGION.

Gordon, John D. Hydrologic data for urban studies in the Austin metropolitan area, Texas, 1984. Austin, Tex. : U.S. Geological Survey, 1986.

(200) R290 no.85-676 D MP

HYDROMETEOROLOGY --ATLANTIC OCEAN.

Giarometeorologicheskoe obespechenie sudokhodstva v IUzhnom okeane. Leningrad : Gidrometeoizdat, 1985.

$510(065)$ G361

HYDROMETEOROLOGY --COLLECTED WORKS .

Trudy Vsesoîunogo nauchno-issledovatelskogo instituta

giarometerologicheskoi informatsii-mirovogo ṫsentra dannykh. Moskva :

Moskovskoe otd-nie. Gidrometeoizdata, 1974-

$P(570)$ G698t

HYDROTHERMAL DEPOSITS--WYOMING--LOWER GEYSER BASIN.

Bargar, Keith E. Hydrothermal alteration in research drill hole $Y-3$, Lower Geyser Basin, Yellowstone National Park, Wyoming. Washington : U.S. G.P.O.; Alexandria, VA : For sale by the Distribution Branch, Text Products Section, U.S. Geological Survey, 1985.

(200) qB no.1054-C D MP

ICEBERGS--CONGRESSES .

Workshop on Ice Scouring (1982 : Montebello, Quebec). Workshop on Ice Scouring, 15-19 February 1982. Ottawa : National Research Council of Canada, Associate Committee on Geotechnical Research, [1985]

$S(100)$ N21st no.136

IDAHO--GEOLOGY--BONNEVILLE COUNTY--MAPS.

Oriel, Steven S. Geologic map of the West and East Palisades Roadless Areas, Idaho and Wyoming. Reston, Va. : U.S. Geological Survey, 1985.

$M(283) 2$ P1760 -- M(200) 4 vUn $3 \mathrm{mf}$ no.1619-B -. M (200) MF no.1619-B

IDAHO--MINERAL RESOURCES--BASIN AND RANGE PROVINCE--MAPS.

Wong, George. Preliminary map of the resource areas in the Basin and Range Province of Idaho. [Menlo Park, Calif.] : U.S. Geological Survey, 1983.

M (283) 4 B292w -- (200) R290 no.83-720 -- (200) R290 no.83-720

IDAHO--MINERAL RESOURCES--BONNEVILLE COUNTY--MAPS .

Mineral resource potential map of the West and East Palisades Roadless Areas, Idaho and Wyoming. Reston, Va. : U.S. Geological Survey, 1985.

M (283) 4 PI760 -- M(200) 4 VUn3mf no.1619-A -- M(200) MF no.1619-A 


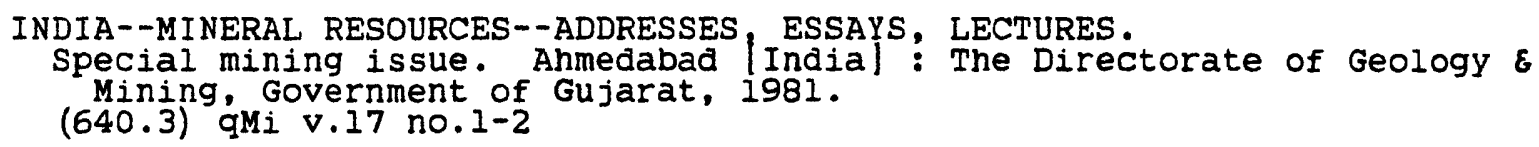

INDIANS OF NORTH AMERICA--WATER RIGHTS.

Gilbert, Bruce K. Hyarolgic [sic] activities of the U.S. Geological survey related to Indian water rights. [Reston, Va.] : U.S. Geological Survey, 1986.

(200) R290 no.86-52

INFORMATION STORAGE AND RETRIEVAL SYSTEMS--WATER-SUPPLY .

MCElwee, Carl D. The Theis equation : evaluation, sensitivity to storage and transmissivity, and automated fit of pumptest data. Lawrence, Kansas : Kansas Geological Survey, 1980, repr. 1984.

(267) K4gws no.3

INSECTS, FOSSIL.

Whalley, P.E. S. The systematics and palaeogeography of the Lower Jurassic insects of Dorset, England. London : British Museum (Natural

History), 1985.

$G(520)$ B $77 \mathrm{bg}$ v.39 no.3

INTERNATIONAL GEOLOGICAL CORRELATION PROGRAMME.

Report of the International Geological Correlation programme (IGCP). Paris : UNESCO, IGCP, IUGS, 1985.

315 qIn8gic no.i3

INVERTEBRATES--COLORADO.

Covay, Kenneth J. Benthic invertebrates in selected streams of the

Piceance Creek basin, northwestern Colorado, water years 1977-81.

Lakewood, Colo.: U.S. Geological Survey, 1985.

(200) WRi no.84-4138 D MP

IONOSPHERIC RADIO WAVE ABSORPTION.

Dopolnitelhye energeticheskie poteri na vysokoshirotnykh radioliniîakh. Moskva : Izd-vo Nauka, 1983.

848.5 D722

IRELAND--DESCRIPTION AND TRAVEL--VIEWS--CATALOGS AND COLLECTIONS.

Ulster Museum. A list of the photographs in the R.J. Welch collection in the UIster Museum. [Belfast, Northern Ireland] : The Museum, 1979-1983. $008(515)$ qui 71

IRELAND--GEOLOGY --KERRY (COUNTY)--GUIDEBOOKS.

Mitchell, G. F; North-west Iveragh, Kerry : autumn excursion, 1983 : guide book. [S.1.j: Irish Association for Quaternary studies, [i983].

G (516) F455 no.6

IRELAND--GEOLOGY--SLIGO (COUNTY)--GUIDEBOOKS.

Sligo and west Leitrim, 1985. [S.I]: Irish Association for quaternary

Studies, [1985].

G (516) F455 no.8

IRELAND--GEOLOGY--TYRONE (COUNTY)--GUIDEBOOKS.

County Tyrone, Northern Ireland. [S.1.] : Irish Association for Quaternary Research, [1980]

$\mathrm{G}(516)$ F 455 no.3 
ISLAND ECOLOGY--OCEANIA.

Dahl, Arthur L. The state of the environment in the South Pacific. Geneva, Switzerland : UNEP, 1983.

537.5 qun22 no.31

JADEITE--SAYAN MOUNTTAINS.

DobreESOv, Nikolai Leontévich. Zhadeit i nefrit $v$ ofiolitakh : na primere Zapadnogo Saiana. Novosibirsk : Nauka, Sibirskoe otd-nie, 1983. $486(690.2)$ D $655 z$

JAPAN--GEOLOGY =-MAPS.

Chishitsu Chōsajo (Japan). Nihon chishitsu atorasu = Geologiçal atlas of Japan. Ibaraki-ken Tsukuba-gun Yatabe-machi : Chishitsu Chosajo, 1982.

R $308(620) \quad$ EC447n 1982 D MP

JORDAN--GEOLOGY--CONGRESSES .

Jordanian Geological Congress (1st : 1982 : Amman, Jordan). Geology of Jordan : proceedings of the First Jordanian Geological [Congress], 6-8th September 1982. Amman, Jordan : Jordanian Geologists Association, 1983. $201(685)$ J767g 1983

KAOLIN.

Husted, John Edwin. Characterization of Georgia kaolins as ores of aluminum. Washington, D.C.: U.S. Bureau of Mines, [1983] $402(233)$ H968C

KIRGHIZISTAN--NATURAL RESOURCES.

Prirodnye kompleksy gornykh territori Frunze : Ilim, 1985.

$580(695.6)$ P938k

KRAKATOA, INDONESIA.

De Neve, G. A. The Krakatau-group and Anak Krakatau's eruptivity : snapshot of 1981 ; Vegetation on Anak Krakatau and reef distribution in the marine environment of the group of Krakatau islands. [Jakarta] : Jurusan Geografi, FIPIA Universitas Indonesia, [1982]

$220(910)$ D $413 k$

LAKE ECOLOGY--NEW HAMPSHIRE--MIRROR LAKE (GRAFTON COUNTY) .

An Ecosystem approach to aquatic ecology : Mirror Lake and its environment. New York : Springer-Verlag, cl985. 554 (212) EC75 MP

LAKES--CONNECTICUT--MASHAPAUG POND.

Connecticut. Dept. of Environmental Protection. Mashapaug Pond, Union, Connecticut : |bathymetric mapl. Hartford, Conn. : The Dept., 1985.

$M(216) 554$ M377C

LAKES--WASHINGTON (STATE)--CLASSIFICATION

Sumioka, S. S. Trophic classification of Washington lakes using reconnaissance data. [Olympia, wash.] : State of wasnington Department of Ecology, 1985.

$780(284)$ W28 no. 57

LAND USE--LIBYA.

Stewart, John Harris. Land and water resources of Tripolitania : a measurement of the land and its potential. Tripoli, Libya : United States Operations Mission to Libya, [1960] $790(710)$ qSt 481 
LAND USE--UTAH.

United States. Bureau of Land Management. Cedar City District. Department of Interior final resource management plan, environmental impact statement for the Cedar/Beaver/Garfield/Antimony planning area, Cedar City District, Utah. Cedar City, Utah : The Bureau. [1984]

$585.3(273)$ Un 34 af a MP only

LANDFORMS--AFRICA, WEST.

Seliverstov, IƯri i Petrovich, Landshafty, i boksity. Leningrad : Izdvo Leningradskogo un-ta, 1983. $540(750)$ Se481

LANDFORMS--BRITISH COLUMBIA--PRINCE GEORGE REGION.

Howes, D. E. Terrain inventory and Late Pleistocene history of the southern part of the Nechako plateau. Victoria, B.C. : Province of British Columbia, Ministry of Environment, Assessment and Planning Division, 1977, repr. 1980 .

$P(180)$ En88ri no.1

LANDFORMS--MONTANA--WALLACE QUADRANGLE--MAPS.

Rowan, Lawrence $C$. Map showing analysis of linear features in the wallace Iipo isx 2ipo isquadrangle, Idaho-Montana. Reston, Va. : U.S. Geological Survey, 1985 .

M(28I) 54 'WI55r -- M(200) 4 vUn3mf no.1354-H -- M(200) MF no.1354-H

LANDSLIDES--WEST VIRGINIA--HUNTINGTON QUADRANGLE--MAPS.

Davies, William E. Landslides and related features, Huntington, west Virginia, Ohio, Kentucky. [Reston, Va.] : U.S. Geological Survey, 1985. M (228) 245 H922d -- (200) R290 no.85-656 - (200) R290 no.85-656

LAOS.

Laos, a country study. 2d ed. Washington, D.C. : for sale by the supt. of Docs., U.S. Govt. Print. Off., cl979. $504(633)$ L 312

LASERS IN SURVEYING.

Avtomatizatsi ià geodezicheskikh izmerenil $v$ meliorativnom stroitelstve. Moskva : Nedra, 1984 .

751 Av97

LAVA--ICELAND.

Niels, Oskarsson. The chemistry of Icelandic lava incrustations and the latest stages of magma degassing. [Reykjavik, Iceland] : Nordic

volcanological Institute, University of Iceland, 1979.

$\mathrm{S}(587)$ qN758r no.79-04

LIBRARIES--AUTOMATION .

Essential guide to the library IBM PC. Westport, CT : Meckler Pub., c1985RO 046.7 ES74

LIBRARIES, DEPOSITORY--UNITED STATES--AUTOMATION--CONGRESSES.

Open Forum on the Provision of Electronic Federal Information to Depository

Libraries (1985 : Wasnington, D.C.). An Open Forum on the Provision of

Electronic Federal Information to Depository Libraries : report of the staff of the Joint Committee on Printing to the chairman of the Joint Committee on Printing : open forum held on June 26, 1985, Washington, DC. Washington, [D.C.] : U.S.G.P.O. : [Supt. of Docs., U.S. G.P.O, distributor], 1985. $\mathrm{P}(200)$ C726po 1985 
LIGNITE--DENMARK.

Grambo-Rasmussen, Allan. Danmarks brunkulsreserver : rapport fase 2 . Is. 1.1: Danmarks Geologiske Undersøgelse, 1984.

461 (585) qG762d

LIGNITE--TEXAS--FREESTONE COUNTY .

Dorsey, M. E. Hydrologic and geochemical data for the Big Brown lignite mine area, Freestone County, Texas. Austin, Tex. : U.S. Geological Survey, 1985.

(200) R290 no.85-338

LIGNITE--TEXAS--STATISTICS .

Kaiser, W. R. Texas lignite, status and outlook to 2000. Austin, Tex.: Bureau of Economic Geology, University of Texas at Austin, 1985.

(245) qT7me no.76

LIMESTONE--AUSTRIA--VORARLBERG.

Uchdorf, Bernd. .Das Rhat in den Vorarlberger Kalkalpen (Österreich) :

Fazies und Paläogeographie. Berlin : D. Reimer, 1984.

$G(530)$ qB455ga Bd.56

LIMNOLOGY--HURON, LAKE--BIBLIOGRAPHY •

Rossmann, Ronald. Lake Huron 1981 intensive surveillance : management and summary. Ann Arbor, Mich. : Great Lakes Research Division, Great Lakes and Marine Waters Center, University of Michigan, [1986] $554(255)$ R7371

LIMNOLOGY--MINNESOTA--HUBBARD COUNTY .

Fishery survey and related limnological conditions of Williams Lake, Hubbard County, Minnesota. Lakewood, Colo.: U.S. Geological Survey, 1985.

(200) WRi no.84-4145 D MP

LOS ANGELES COUNTY FLOOD CONTROL DISTRICT--STATISTICS--PERIODICALS.

Hyarologic report (Los Angeles County Flood Control District). Hydrologic report. LoS Angeles, CA. The District.

$\mathrm{S}(276) \mathrm{H} 995$

MAGMATISM--URAL MOUNTAIN REGION--ADDRESSES, ESSAYS, LECTURES.

Geologi ia magmaticheskikh obrazovanii severa Urala i Timana. Syktyvkar : Komi filial AN SSSR, 1984.

$G(570)$ AkI $44 t$ vyp. 48

MAGNESIUM INDUSTRY AND TRADE--CALIFORNIA.

Majmundar, Hasmukhrai $\mathrm{H}$. Mineral commodity report, magnesium compounds. Sacramento, Calif. : California Department of Conservation, Division of Mines and Geology, 1985.

(276) qC4spp no.77

MAGNETIC ANOMALIES--UKRAINE--CONGRESSES.

Soveshchanie na temu "Is ledovanie regionalfykh magnitnykh anomali platformennykh oblasstei" (1982: Yalta). Issledovanie regionalhykh magnitnykh anomali i platformennykh oblasteí : sbornik nauchnykh trudov. Kiev : Nauk. dumka, 1984.

$296(571)$ So88i

MAGNETOPAUSE.

Roth, Michel. La structure interne de la magnétopause. Bruxelles : Palais des Académies, 1984.

$S(593)$ Ac23 ser.2 tome 44 fasc. 7 
MAGNETOTELLURIC PROSPECTING.

Anderson, Walter L. An album of three-dimensional transient

electromagnetic responses for the central-induction loop configuration. [Denver, CO] : U.S. Geological Survey, 1985.

(200) R290 no.85-745 D MP

MAINE--GEOLOGY--AROOSTOOK COUNTY--MAPS.

Roy, David C. Geologic map of a portion of northeastern Aroostook County, Maine. Augusta : Maine Geological Survey, 1978.

$M(211) 2$ Ar67r

MAINE--GEOLOGY--ASHLAND QUADRANGLE--MAPS .

Roy, David C. Bedrock geology of the Ashland $15^{\prime}$ quadrangle and

surrounding area, Maine. [Augusta] : Maine Geological Survey, 1978. $M(211) 2$ sq As35r

MAINE--GEOLOGY --BANGOR QUADRANGLE--MAPS.

Griffin, John R. Reconnaissance bedrock geology of the Bangor quadrangle, Maine. Augusta : Maine Geological Survey, 1976. $M(211) 2$ sq B225g

MAINE--GEOLOGY--BATH QUADRANGLE--MAPS .

Hussey, Arthur M. Reconnaissance bedrock geology of the Bath and Small

Point quadrangles, Maine. Augusta : Maine Geological Survey, 1981.

$M(211) 2$ sq $B 322 \mathrm{~h}$

MAINE--GEOLOGY--BUCKFIELD QUADRANGLE--MAPS.

Pankiwskyj, Kost A. Reconnaissance bedrock geology of the northern part of the Buckfield quadrangle and adjoining Dixfield quadrangle. Augusta : Maine Geological Survey, 1981.

M (211) 2sr B855p 1981

MAINE--GEOLOGY--BUCKSPORT OUADRANGLE--MAPS.

Griffin, John R. Reconnaissance bedrock geology of the Bucksport

quadrangle, Maine. Augusta : Maine Geological Survey, 1976.

$M(211) 2 s q$ B857g

MAINE--GEOLOGY--CALAIS QUADRANGLE--MAPS.

Ludman, Allan. Reconnaissance bedrock geology of the Calais quadrangle, Maine. Augusta : Maine Geological Survey, 1977.

$M(211) 2$ sq CI251

MAINE--GEOLOGY--CASCO BAY QUADRANGLE--MAPS.

Hussey, Arthur M. Reconnaissance bedrock geology of the Casco Bay quadrangle, Maine. Augusta : Maine Geological Survey, 1981.

$M(211) 2$ sq $C 266 \mathrm{~h}$

MAINE--GEOLOGY--CONGRESSES.

Guidebook for field trips in the Greenville - Millinocket regions, north central, Maine : New England Intercollegiate Geologic Conference ; 75th annual meeting, october 7,8, and 9, 1983. [s.1.: s.n., 1983]

$G(210)$ N42gf no.75

MAINE--GEOLOGY--DANFORTH QUADRANGLE--MAPS .

Ludman, Allan. Report of mapping progress - 1980 - Danforth, Forest, Scraggly Lake and Waite quadrangles, Eastern Maine. Augusta : Maine Geological Survey, 1980.

M(211) 2sr Ea771 
MAINE--GEOLOGY--EASTPORT QUADRANGLE--MAPS.

Gates, Olcott. Preliminary bedrock and brittle fracture map of the

Eastport 21p0is sheet, Maine. Augusta : Maine Geological Survey, 1982.

M (211) 2sr Ea78g

MAINE--GEOLOGY--FREDERICTON QUADRANGLE--MAPS.

Ludman, Allan. Preliminary bedrock and brittle fracture map of the

Fredericton 21 po issheet, Maine. Augusta : Maine Geological Survey, 1982. $M(211) 2$ sr F8721

MAINE--GEOLOGY--FREEPORT QUADRANGLE--MAPS .

Hussey, Arthur M. Reconnaissance bedrock geology of the Freeport 15' quadrangle, Maine. Augusta : Maine Geological survey, 1981. $M(211) 2 \mathrm{sq}$ F878h

MAINE--GEOLOGY--GARDINER QUADRANGLE--MAPS .

Newberg, Donald W. Reconnaissance bedrock geology of the Gardiner

quadrangle, Maine. Augusta : Maine Geological Survey, 1981.

$M(211) 2 s r$ Gl68n

MAINE--GEOLOGY--GREAT POND QUADRANGLE--MAPS.

Griffin, John $R$. Reconnaissance bedrock geology of the Great Pond quadrangle, Maine. Augusta : Maine Geological Survey, 1976.

$M(211) 2 s q$ G798g

MAINE--GEOLOGY--LIBERTY QUADRANGLE--MAPS.

Pankiwskyj, Kost A. Preliminary geologic map of the Liberty 15'quadrangle and adjoining parts of the Burnham, Brooks, Belfast, and Vassalboro quadrangles, Maine. Augusta : Maine Geological Survey, 1976.

$M(211) 2 s r$ L615p

MAINE--GEOLOGY--MAPS.

Osberg, Philp Henry. Bedrock geologic map of Maine. Augusta : Maine Geological Survey, 1984.

$M(211) 2$ sr 19840

Pankiwskyj, Kost A. Preliminary geologic map of selected parts of the Wiscasset, vassaiboro, Liberty, Burnham, Belfast, Brooks, and Bucksport quadrangles, Southern Maine. Augusta : Maine Geological Survey, 1976. $M(211) 2 s r$ W752p

MAINE--GEOLOGY--ORLAND QUADRANGLE--MAPS.

Griffin, John R. Reconnaissance bedrock geology of the orland quadrangle, Maine. Augusta : Maine Geological Survey, 1976.

$M(211) 2 \mathrm{sq}$ Or $5 \mathrm{~g}$

MAINE--GEOLOGY--ORONO QUADRANGLE--MAPS.

Griffin, John R. Reconnaissance bedrock geology of the orono quadrangle, Maine. Augusta : Maine Geological Survey, 1976. $M(211) 2 \mathrm{sq}$ or $6 \mathrm{~g}$

MAINE--GEOLOGY--PASSADUMKEAG QUADRANGLE--MAPS .

Griffin, John R. Reconnaissance bedrock geology of the Passadumkeag

quadrangle, Maine. Augusta : Maine Geological Survey, 1976.

$M(211) 25 q$ P266g 
MAINE--GEOLOGY--PISCATAQUIS COUNTY--MAPS.

Pankiwskyj, Kost A. Geologic map of the southern part of Piscataquis County, Maine. Augusta : Maine Geological Survey, 1979.

$M(211) 2$ sr P673p

MAINE--GEOLOGY --POLAND QUADRANGLE--MAPS .

Creasy, John $w$. Reconnaissance bedrock geology of the Poland quadrangle, Maine. Augusta : Maine Geological Survey, 1979. $M(211) 2$ sr P758c

MAINE--GEOLOGY--SAPONAC QUADRANGLE--MAPS .

Griffin, John $R$. Reconnaissance bedrock geology of the saponac quadrangle, Maine. Augusta : Maine Geological Survey, 1976. $M(211) 2 s q$ Sa68g

MAINE--GEOLOGY--SHERBROOKE QUADRANGLE--MAPS.

Westerman, David S. Report on field mapping in the Sherbrooke 2 degree quadrangle, Northwestern Maine. Augusta : Maine Geological Survey, 1979. $M(211) 2$ sr Sh52w

MAINE--GEOLOGY--SHERMAN QUADRANGLE--MAPS .

Roy, David C. Reconnaissance bedrock geology of the Sherman, Mattawamkeag, and Millinocket 15'quadrangles, Maine. Augusta : Maine Geological Survey, 1981.

M (211) 2sr Sh56r

MAINE--GEOLOGY--THE FORKS QUADRANGLE--MAPS .

Burroughs, William A. Reconnaissance bedrock geology of The Forks quadrangle, Maine. Augusta, Me. : Maine Geological Survey, 1981. $M(211) 2$ sq F764b

MAINE--GEOLOGY--UPPER ST. JOHN RIVER REGION--MAPS.

Roy, David C. Reconnaissance bedrock geology of the Upper St. John River Area, Northwestern Maine. Augusta : Maine Geological Survey, 1982. $M(211)$ isr Upбri

MAINE--GEOLOGY--WESLEY OUADRANGLE--MAPS .

Westerman, David S, Reconnaissance bedrock geology of the Wesley 15' quadrangle, Maine. Augusta : Maine Geological Survey, 1981.

$M(211) 2$ sq W516w

MAINE--PETROLOGY--PISCATAQUIS COUNTY

Philbrick, Shailer shaw. The contact metamorphism of the Onawa pluton, Piscataquis County, Maine. [1933]

$150.3(211)$ qP535C

MAMMALS--CLASSIFICATION.

Wesselman, Henry Bernard. The Omo micromammals : systematics and paleoecology of early man sites from Ethiopia. Basel ; New York : Karger, 1984.

915 C333 v. 7

MAMMALS, FOSSIL.

Sutcliffe, Antony John. On the track of ice age mammals. London : British Museum (Natural History), 1985.

679 Su830 
MAMMALS, FOSSIL--ADDRESSES, ESSAYS, LECTURES .

Gingerich, P. D. Mammals : notes for a short course. [Knoxville, Tenn.]: University of Tennessee, Dept. of Geological Sciences, 1984.

$G(239)$ St 94 no.8

MAMMALS, FOSSIL--FRANCE--PROVENCE.

Godinot, Marc. Les mammifères de Rians (Eocène inférieur, Provence).

[Paris]: Laboratoire de paléontogolgie des vertébrés de l'école

pratique des nautes études : Montpelilier : Laboratoire de paléontologie de I'Université des sciences et techniques du Languedoc, [1981] $602(540)$ PI72 v.10 fasc.2

MANCHURIA--GEOLOGY .

Ushimaru, Shutaro. Geology of the route between Chao-yang-chuan Station and Kai-shan-tun station on the Tien-pac-shan to Tu-men-chiang Railway Line, Manchuria. Tokyo, Japan : U.S. Geological Survey, [1954] $209(900)$ qun33pr [no.476]

MANGANESE MINES AND MINING, SUBMARINE.

Holser, Alexander $F$. Manganese nodule resources and mine site availability. [Washington] : ocean Mining Administration, [1976] $433 \mathrm{H} 743 \mathrm{~m}$

MAP COLLECTIONS--UNITED STATES--DIRECTORIES. Cobb, David A. Guide to U.S. map resources. Chicago, Ill. : American Library Association, C1986.

R 508.4(200) qCE34g D MP

MARINE MINERAL RESOURCES--COLLECTED WORKS.

Beitrage zur Meerestechnik. Beitrage zur Meerestechnik. ClausthalZellerfeld : Die Arbeitsgruppe. $S(530)$ qB397m

MARINE POLLUTION.

Marine pollution. Geneva, Switzerland : UNEP, 1983.

537.5 qun22 no.25

MARINE POLLUTION--AFRICA, EAST.

Marine pollution in the East African region. Geneva, Switzerland : UNEP, 1982 .

537.5 qun22 no.8

UNEP Regional Seas Programme : the eastern African experience. Geneva, Switzerland : Programme Activity Centre for Oceans and Coastal Areas, United Nations Environment Programme, 1984.

537.5 qun22 no.53

MARINE POLLUTION--ENVIRONMENTAL ASPECTS--AFRICA, WEST.

Action plan for the protection and development of the marine environment and coastal areas of the West and Central African region. Geneva, Switzerland : Regional Seas Programme Activity Centre, UNEP, 1983.

537.5 qun22 no.27

MARINE POLLUTION--ENVIRONMENTAL ASPECTS--CARIBBEAN AREA.

Action Plan for the Caribbean environment programme. Geneva, Switzerland : UNEP, 1983.

537.5 qun22 no. 22 
MARINE POLLUTION--ENVIRONMENTAL ASPECTS--CARIBBEAN SEA.

The State of marine poliution in the wider Caribbean region. Geneva, Switzerland : Regional Seas Programme Activity Centre, United Nations Environment Programme, 1984.

537.5 qun22 no.36

MARINE POLLUTION--ENVIRONMENTAL ASPECTS--EAST ASIA.

Action plan for the protection and development of the marine and coastal areas of the East Asian region. Geneva, Switzerland : Regional Seas Programme Activity Centre, UNEP, 1983. 537.5 q Un 22 no. 24

MARINE POLLUTION--ENVIRONMENTAL ASPECTS--PERSIAN GULF.

Action plan for the protection of the marine environment and the coastal areas of Bahrain, Iran, Iraq, Kuwait, Oman, Qatar, Saudi Arabia, and the United Arab Emirates. Geneva, Switzerland : UNEP, 1983. 537.5 qun22 no.35

MARINE POLLUTION--ENVIRONMENTAL ASPECTS--SOUTH PACIFIC OCEAN.

Action Plan for the protection of the marine environment and coastal areas of the South-East Pacific ; prepared in co-operation with Comision Permanente del Pacifico Sur. Geneva, Switzerland : UNEP, 1983. 537.5 qun 22 no. 20

MARINE POLLUTION--MEASUREMENT.

Prospects for global ocean pollution monitoring. Geneva, Switzerland : Regional Seas Programme Activity Centre, UNEP, 1984. 537.5 qun22 no.47

MARINE POLLUTION--MEDITERRANEAN SEA.

Arab co-operation for the protection and development of the marine environment and coastal areas resources of the Mediterranean. Geneva, Switzerland : Regional Seas Programme Activity Centre, UNEP, 1984. 537.5 qun22 no. 52

Pollutants from land-based sources in the Mediterranean. Geneva, Switzerland : UNEP, 1984. 537.5 qun22 no. 32

MARINE POLLUTION--MEDITERRANEAN SEA--CONGRESSES .

Workshop on Pollution of the Mediterranean (4th : 1978 : Antalya, Turkey). IVes Journées d'études sur les pollutions marịnes en Méditterranée : Antalya, 24-27, novembre 1978. Monaco : Secrétariat général de la Commission, 1979 .

$537.5(059)$ W893 1978

Workshop on Pollution of the Mediterranean (5th : 1980 : Cagliari, Sardinia). Ves Journées d'études sur les pollutions marines en Méditerranée : Cagliari, 9-13 octobre 1980. Monaco : Secrétariat général de la Commission, 1981 .

$537.5(059)$ W893 1980

Workshop on Pollution of the Mediterranean (6th : 1982 : Cannes, France) . VIes J̦ournées d'études sur les pollutions marines en Méditerranée : Cannes, 2-4 décembre 1982. Monaco : Secrétariat général de la C.I.E.S.M., 1983. $537.5(059)$ W893 1982 
MARINE POLLUTION--MEDITERRANEAN SEA--MEASUREMENT.

Long-term programme for pollution monitoring and research in the

Mediterranean (MED POL) - Phase II. Geneva, Switzerland : UNEP, 1983.

737.5 qun22 no.28

MARINE POLLUTION--MEDITERRANNEAN SEA--CONGRESSES.

Journées d'études sur les pollutions marines (3ró : 1976 : Split,

Yugoslavia). Protection du littoral méditerranéen : IIIes Journées d'

études sur les pollutions marines, Split, 22-23 octobre 1976 ; compte rendu

des travaux du Comité de lutte contre les pollutions marines durant le XXVe Congres-Assemblée pléniere. Monaco : Secrétariat général de la

Commission, 1977.

$537.5(059)$ W893 1976

MARINE RESOURCES--AFRICA, EAST.

Marine and coastal area development in the East African region. Geneva, Switzerland : UNEP, 1982.

537.5 qun 22 no. 6

MARINE RESOURCES--AFRICA, WEST.

The Marine and coastal environment of the west and Central African region and its state of pollution. Geneva, Switzerland : Programme Activity Centre

for Oceans and Coastal Areas, UNEP, 1984.

537.5 qun22 no.46

MARINE RESOURCES--ECONOMIC ASPECTS--AFRICA, EAST.

Socio-economic activities that may have an impact on the marine and coastal environment of the East African region : national reports. Geneva,

Switzerland : Programme Activity Centre for Oceans and Coastal Areas, UNEP, 1984.

537.5 qun22 no.51

MARINE RESOURCES--LAW AND LEGISLATION--AFRICA, EAST.

Legal aspects of protecting and managing the marine and coastal environment of the East African region : national reports. Geneva, Switzerland :

Regional Seas Programme Activity Centre, United Nations Environment Programme, 1984 .

537.5 qun 22 no. 49

MARINE SEDIMENTS.

Frolov, V. T. Geneticheskaîa tipizaEsîâ morskikh otlozhenil. Moskva : Nedra, 1984.

536 F925gt

MARINE SEDIMENTS--ADDRESSES, ESSAYS, LECTURES .

Osadkonakoplenie $v$ shelfovykh zonakh : sbornik nauchnykh trudov.

Leningrad : PGO "Sevmorgeologi ia", 1983.

$536(570)$ OsIV

MARINE SEDIMENTS--ANTARCTIC REGIONS.

USCGC Glacier : Operations Deep Freeze 1982 and 1983 sediment descriptions. Tallahassee, Fla. : Antarctic Research Facility, Dept. of Geology, Florida State University, 1984.

$G(234)$ qF $663 \mathrm{C}$ no.52

MARINE SEDIMENTS--INDIAN OCEAN.

Svalkov, V. N. Chetvertichnoe osadkoobrazovanie v vostochnoi chasti Indiiskogo okeana. Moskva : Nauka, 1983. $536(530.7)$ SVI4C 
MARKET SURVEYS.

Editor \& publisher. Editor \& publisher market guide, 1986. New York : Editor \& Publisher Company, cl986.

065 Ed48 1986 F only

MATHEMATICAL STATISTICS--TABLES, ETC.--COLLECTED WORKS.

Selected tables in mathematical statistics. Selected tables in mathematical statistics. Providence, R.I.: American Mathematical Society.

$067 \mathrm{Se} 48$

MAURITANIA--GEOLOGY .

Lécorché, Jean-Paul. Les Mauritanides face au craton ouest-africain structure d'un secteur-clé : Ia région d'Ijibiten (est d'Akjoujt, R.I. de Mauritanie). St. Jéróme, Marseille : Facuité des sciences et techniques de Saint Jérome, 1985.

$G(540)$ qP498tb no 26

MEDITERRANEAN POLLUTION MONITORING AND RESEARCH PROGRAMME.

Co-ordinated Mediterranean Pollution Monitoring and Research Programme (MED POL) : Phase I, programme description. Geneva, Switzerland : UNEP, 1984. 537.5 qun 22 no. 23

MERCURY ORES--ALASKA--DECOURCY MOUNTAIN REGION.

Webber, Edward J. Quicksilver deposits in the DeCourcy Mountain area, Iditarod District, southwestern Alaska. [Washington] : U.S. Geologica] Survey, [1944?]

PAM FILE

METASOMATISM (MINERALOGY) .

Shcherban, I. P. Okoloruanye metasomatity kontinentalhykh riftogennykh struktur. Moskva : Nedra, 1985.

$190 \mathrm{Sh} 320$

METASOMATISM (MINERALOGY)--CONGRESSES .

Vsesoîuznaîa konferentsi ia "Metasomatizm i rudoobrazovanie" (5th :

1982 : Leningrad). Metasomatizm i rudoobrazovanie. Moskva : Nauka, 1984 .

$283(570) \mathrm{v} 968 \mathrm{~m}$

METEORITES--CZECHOSLOVAKIA.

Tucek, Karel. Meteority a jejich výskyty v Ceskoslovensku. Praha : Academia, 1981 .

$s(532)$ C338v no.28

METEOROLOGICAL OPTICS.

Krekov, Georgii Mikhailovich. Optiko-lokaEsionnaîa model' kontinentalfogo aerozolia. Novosibirsk : Nauka, Sibirskoe otd-nie, 1982 .

$511 \mathrm{~K} 8820$

METEOROLOGICAL OPTICS--STATISTICAL METHODS.

Primenenie korrelî́t Novosibirsk : Nauka, Sibirskoe otd-nie, 1983.

511 P935 
MEXICO--MINERAL RESOURCES--PERIODICALS.

Bolet in de mineralogia (México, D.F.j). Boletin de mineralogia.

Mexico, D.F. : La Sociedad, 1985-

$G(300)$ B537m

MICHIGAN, LAKE.

Larsen, Curtis E. A stratigraphic study of beach features on the southwestern shore of Lake Michigan : new evidence of Holocene lake level fluctuations. Champaign, III. : Illinois State Geological Survey, 1985. (253) qII6eg no.112

MICROCOMPUTERS--COMPUTER PROGRAMS--PERIODICALS.

Technotes (Culver City, Calif.). TechNotes. Torrance, Calif. : AshtonTate Sof tware Support Center, 1985039.2 T226

MICROCOMPUTERS--LIBRARY APPLICATIONS--DIRECTORIES .

Directory of microcomputer applications in libraries. San Jose, Calif. : CLASS, [1984]

R 036.23 D628

MICROPALEONTOLOGY--MEXICO, GULF OF.

Pyle, Thomas Edward. Micropaleontology and mineralogy of a Tertiary

sediment core from the Sigsbee Knolls, Gulf of Mexico. College Station, Tex. : Texas A\&M University, Dept. of Oceanography, 1966.

$S(245)$ Tl7otr no.66-13T

MINE SUBSIDENCES.

Turney, J.E. Subsidence above inactive coal mines : information for the homeowner. Denver, Colorado : Department of Natural Resources, 1985. (271) qC3sp no.26

MINERAL INDUSTRY--CANADA--COLLECTED WORKS.

Technical paper (Queen's University (Kingston, ont.). Centre for Resource Studies). Technical paper. Kingston, Ont. : The Centre, [cla81]$S(150)$ T226

MINERAL INDUSTRY--DEVELOPING COUNTRIES.

Walrond, G. W. Options for developing countries in mining development. New York : St. Martin's Press, 1986. 420 W1660

MINERAL INDUSTRY--SPAIN--PERIODICALS.

Industria minera (Madrid, Spain). Industria minera. Madrid : El Consejo. $G(560)$ qIn2

MINERAL INDUSTRY--TEXAS.

Ohl, Jane P. The mineral industry of Texas in 1983. Austin, Tex. : Bureau of Economic Geology, University of Texas at Austin, [1985] (245) qT7me no.77

MINERAL RESOURCES--COLORADO.

Availability of federal land for mineral exploration and development in western states: Colorado, 1984. [Washington, D.C.?]: U.S. Dept. of the Interior, Bureau of Mines, 1985. 402 (271) qưn $34 \mathrm{ac}$ 
MINERAL RESOURCES CONSERVATION--SIBERIA--ADDRESSES, ESSAYS, LECTURES . Kompleksnoe ispolzovanie i okhrana mineralhogo syria sibiri. Novosibirsk: Nauka, Sibirskoe otd-nie, 1982. $585.3(690) \mathrm{K} 836$

MINERAL RESOURCES--EUROPE--MAPS. Mémoire explicatif de la carte métallogénique de l'Europe et des pays limitrophes = Explanatory memoir of the metallogenic map of Europe and neighbouring countries : 1:2 500 000. Paris : Unesco, 1984. 209 qEa76s no.17

MINERALOGICAL CHEMISTRY--MATHEMATICAL MODELS. Fliuidnye postmagmaticheskie sistemy. Novosibirsk : Nauka, Sibirskoe otdnie, 1983. 119 F652

\section{MINERALOGY}

Hofmann, Fritz. Rare and beautiful minerals. New York : Exeter Books ; dist. by Bookthrift, 1981. $104 \mathrm{H} 675 \mathrm{r}$

Popov, V. A. Prakticheskaîa kristallomorfologi价 mineralov. Sverdlovsk : UNTS AN SSSR, 1984. $120 \mathrm{P} 814 \mathrm{p}$

MINES AND MINING--ARKANSAS.

Field trip guide to three major mines in central Arkansas. Little Rock, Ark. : Arkansas Geological Commission, 1979.

(241) Ar7g [no.79-3]

MINES AND MINING--GEORGIA--TRAY MOUNTAIN REGION--MAPS.

Chatman, Mark L. Maps showing mines, prospects, and mineral sites in the Tray Mountain Roadless Area and vicinity, Northern Georgia. Reston, Va. : U.S. Geological Survey, 1985.

M(233) 42 T698C -- M(200) 4 vUn3mf no.1347-C -- M(200) MF no.1347-C

MINES AND MINING--WASHINGTON (STATE)--SNOHOMISH COUNTY--MAPS.

Mines and prospects map of the Glacier Peak Roadless Area, Snohomish County, Washington. Reston, Va. : U.S. Geological Survey, 1985.

M (284) 42 G451j -- M(200) 4 vUn3mf no.1380-E -- M(200) MF no.1380-E

MINING ENGINEERING.

Podzemnye mekhanizirovannye bunkera. Moskva : Nedra, 1985. 425 P752

MINING SCHOOLS AND EDUCATION--LAW AND LEGISLATION.

Hanshaw, Bruce B. Report of the Ad Hoc Committee on the Mining and Mineral Resources Research Institute Program of the Department of the Interior. [Washington, D.C. : Department of the Interior?, 1980] $403(200)$ HI98r

MINNESOTA--GEOLOGY--MAPS.

Sims, P. K. Generalized bedrock geologic map of west-central vermillion

district, Northern Minnesota. Reston, Va. U.S. Geological Survey, 1985. $M((261) 2$ V592s -- M(200) 2 vUn3m no.1529 -. M(200) I no.1529 
MISSOURI--GEOLOGY--GORDONVILLE QUADRANGLE--MAPS.

Amos, Dewey Harold. Geologic map of the Gordonville quadrangle, Cape

Girardeau County. Missouri. Reston, Va. : U.S Geological Survey, 1985. $M(263) 2$ G658a -- M(200) 4 vUn3mf no.1823 -- M(200) MF no.1823

MOLLUSKS, FOSSIL--UKRAINE.

IAmnichenko, Ivan Moìseevich. IUrskie i melovye mollîuski Ukrainy : paleontologicheskii spravochnik. Kiev : Nauk. dumka, 1984. $654(571)$ Ia6i

MOLYBDENUM ORES--TRANSBAIKALIA.

Baturina, E. E. Molibdenovye i volframovye mestorozhdeniTa Zapadnogo

Zabaikaliầ : osnovnye cherty metallogenii i geokhimii. Moskva : Nauka, 1984.

$439(690.3) \quad B 322 \mathrm{~m}$

MOON--PERIODICALS.

The Moon. Dordrecht, Holland; Boston : R. Reidel Pub. Co., 1969-1977.

736 M778

MOUNTAINS--ADDRESSES, ESSAYS, LECTURES.

Problemy geomorfologii gor. Moskva : Nauka, 1984. 293 P942

MUNICIPAL WATER SUPPLY--VIRGINIA.

Municipally owned water supply systems, southwest region. Richmond, Va. : Commonwealth of Virginia, State Water control Board, Southwest Regional Office, Bureau of Water Control Management, [1983]

$P(227)$ qw292b no.51

NAMES, GEOGRAPHICAL--GREAT BRITAIN.

Geliing, Margaret. Place-names in the landscape. London : Dent, 1984.

$506(510)$ G283p

NATIONAL EARTHQUAKE PREDICTION EVALUATION COUNCIL (U.S.) .

National Earthquake Prediction Evaluation Council (U.S.). Minutes of the National Earthquake Prediction Evaluation Council : September 8 \& 9, 1985 , Anchorage, Alaska. Reston, Va. : U.S. Geological Survey, [1986] (200) R290 no.86-92 D MP

NATURAL AREAS.

The World's greatest natural areas : an indicative inventory of natural sites of world heritage quality. Gland, Switzerland : CNPPA, [1982?]

585.7 W893

NATURAL GAS--AUSTRALIA--CANNING BASIN.

Canning Basin Symposium (1984 : Perth, w. Aust.). The Canning Basin, w.A. Perth, W.A. : Geological Society of Australia, Western Australian Branch, 1984 .

$201(860) \quad \mathrm{CC} 164$

NATURAL GAS--LOUISIANA.

Hicks, James, $N$. Gas deliverability and flow capacity of surveillance gas fields in Louisiana and Texas Federal of shore Areas. Wasnington, D.C. : Energy Information Administration, Office of Oil and Gas, U.S. Dept. of Energy, 1986.

P (200) Enz8eia no.0471 
NATURAL GAS--RESERVES--STATISTICS--YEARBOOKS .

Oil \& gas reserve disclosures. Chicago, Iil. : The company.

R 467.7 Oi5g

NATURAL RESOURCES--AFRICA, EAST.

Marine and coastal conservation in the East African region : national reports. Geneva, Switzerland : UNEP, 1984. 537.5 qun 22 no. 50

NATURAL RESOURCES--ENVIRONMENTAL ASPECTS.

The State of the environment, 1985. Paris : The Organisation, 1985.

582 st 28

NATURE CONSERVATION--CONGRESSES.

International Biosphere Reserve Congress (1st : 1983 : Minsk, Byelorussian $s$.

S.R.). Conservation, science and society : contributions to the First

International Biosphere Reserve Congress, Minsk, Byelorussia/USSR, 26

September - 2 October 1983. Paris : Unesco, 1984.

580 qun $32 \mathrm{nr}$ no.21

NEBRASKA--WATER-SUPPLY .

Steele, Eugene $K$. Estimate of self-supplied domestic water use in Nebraska

during 1980. Lincoln, Nebraska : U.S. Geological Survey, 1985.

(200) WRi no.85-4257 D MP

NEVADA--CLIMATE.

Spaulding, Waiter Geoffrey. Vegetation and climates of the last 45,000

years in the vicinity of the Nevada Test Site, south-central Nevada.

Washington : U.S. G.P.O., 1985.

(200) qB no.1329 D MP F

NEVADA--GEOLOGY--GUIDEBOOKS.

Guidebook to the northern Sierra Nevada $\varepsilon$ Reno - Lake Tahoe areas : National Association of Geology Teachers, Far Western Section, Fall Meeting, October 4-6, 1985, Mackay School of Mines, University of Nevada - Reno. [s.1. : s. n... 1985]

G(200) qN213fg oct.4-6 1985

NEVADA--GEOLOGY--MT. ROSE NE QUADRANGLE--MAPS.

Bonham, H. F. Geologic map, Mt. Rose NE quadrangle. Reno, Nev. : Nevada Bureau of Mines and Geology, 1983.

$M(275) 2$ M865b

NEVADA--GEOLOGY--YERINGTON REGION--MAPS .

Proffett, John Maddon. Geologic map of the Yerington district, Nevada.

Washington, D.C. : Williams and Heintz Map Corp., 1984.

$M(275) 2$ Y $44 \mathrm{P}$

NEVADA--WATER-SUPPLY .

Lamke, Robert $D$. Interim inventory of surface water resources of Nevada.

[Carson City?] State of Nevada, Dept. of Conservation and Natural Resources, 1965.

$780(275)$ N4lwb no.30

NEW MEXICO--GEOLOGY--ANTHONY QUADRANGLE--MAPS .

Kelley, Shari. Geology of Anthony quadrangle, Doña Ana County, New Mexico. Socorro, N.M. : New Mexico Bureau of Mines \& Mineral Resources, 1983. $M(272) 2$ An86k 
NEW MEXICO--GEOLOGY--CHILI QUADRANGLE--MAPS.

Dethier, David P. Geologic map of the Chili quadrangle, Rio Arriba County,

New Mexico. Reston, Va.: U.S. Geological survey, 1985.

$M(272) 2$ C438d -- M (200) 4 vUn3mf no.1814 - M (200) MF no.1814

NEW MEXICO--GEOLOGY--ESPAÑOLA BASIN--MAPS .

Kelley, Vincent Cooper. Geology of Española Basin, New Mexico. Socorro :

New Mexico Bureau of Mines \& Mineral Resources, 1978.

$M(272) 2$ Es62k

NEW YORK (STATE) --GEOLOGY--GUIDEBOOKS.

Field trip guidebook, New York State Geological Association, 56th Annual

Meeting, September 21-23, 1984. Clinton, N.Y. : Dept. of Geology,

Hamilton College, $[1984]$

$\mathrm{G}(221)$ qN42fg no.56

NEW YORK (STATE)--GEOLOGY--PENNELLVILLE QUADRANGLE--MAPS.

Milier, Todd S. Surficial geology of Pennellville quadrangle, oswego

County, New York. [Reston, Va.] : U.S. Geological Survey, 1980.

$M(221) 2$ P $382 \mathrm{~m}$

NEWFOUNDLAND--GEOLOGY--GUIDEBOOKS.

Williams, Harold. The regional setting and structure of the west

Newf oundland ophiolites. [S.1.: s.n., 1974?]

G(100) G29g May 1974 A-2

NONFERROUS METALS--TRANSBAIKALIA.

Kozlov, valerii Dmitrievich. Geoknimîia i rudonosnost'granitoidov

redkometalkykh provinEsii. Moskva : Nauka, 1985.

$425.2(690.3)$ K8489

NORTH AMERICA--MAPS.

National Geographic Society (U.S.). Atlas of North America : Space Age protrait of a continent. Washington, D.C. : The Society, 1985.

R $508(200)$ ffN $213 a$

NORWAY--GEOLOGY--RANDS FJORD--MAPS.

Kjaernes, Per Arne. Gran, beskrivelse til kvartaergeologisk kart 1815 I M 1:50 000 (med fargetrykt kart) = Gran, description of the quaternary geological map 1815 I - 1:50,000. Tronaheim, Norway :

Universitetsforlaget, 1984 .

(581) Bs nr.53

NORWAY--GEOLOGY--TROMS COUNTY--MAPS .

Bargel, Terje H. Altevatn, beskrivelse til kvartaergeologisk kart 1532 II M 1:50 000 (Med fargetrykt kart): Altevatn, description of the Quaternary geological map 1532 II - 1:50,000. Trondheim, Norway: Universitetsforlaget, 1984.

(581) Bs nr.52

NORWAY--GEOLOGY--TRONDHEIM FJORD--MAPS .

Reite, Arne J. Hølonda, Beskrivelse til kvartaergeologisk kart 1521 II - M l:50 000 (Med fargetrykt kart) $=$ Hølonda, Description of the quaternary geological map 1521 II (scale 1:50,000). Trondheim : Universitetsforlaget, 1984 .

(581) Bs no. 54 
OCEAN-ATMOSPHERE INTERACTION .

Izmenchivost'fizicheskikh polei $v$ atmosfere nad okeanom. Moskva : Nauka, 1983.

530 I 4

OCEAN BOTTOM--NORTH PACIFIC OCEAN.

Structure of the floor of the northwestern Pacific Ocean : geophysics, magmatism, tectonics = Stroenie dna severo-zapada Tikhogo Okean : geofizika, magmatizm, tektonika. [Reston, Va.]: The Survey, [1984]

$203(081)$ St87E

OCEAN ENERGY RESOURCES--AFRICA, WEST.

Ocean energy potential of the West African region. Geneva, Switzerland : UNEP, 1983.

537.5 qun22 no. 30

OCEAN ENGINEERING--CONGRESSES.

ECOR International Conference (4th : 1981 : London). The management of oceanic resources : the way ahead : proceedings of an international conference, London 7,8 and 9 April, 1981. Los Angeles: Published for ECOR by the Institute for Marine and Coastal Studies, [1981]

537.1 In8m

OCEAN TEMPERATURE--NORTH ATLANTIC OCEAN--CLIMATIC FACTORS.

Klimatologo-statisticheskoe issledovanie termogalinnykh poleĭ severnoi

Atlantiki. Moskva : Moskovskoe otd-nie Gidrometeoizdata, 1982.

$530.1 \mathrm{~K} 683 \mathrm{i}$

OCEAN WAVES.

Selezov, $\dot{I}$. T. TransformaEsîîa voln $\mathrm{v}$ pribrezhnoi zone shelfa. Kiev : Nauk. dumka, 1983.

$533 \mathrm{Se} 48 \mathrm{t}$

OCEANOGRAPHIC RESEARCH STATIONS--CHESAPEAKE BAY.

Environmental data sources for the Chesapeake Bay area. Washington, D.C. : U.S. Dept. of Commerce, National Oceanic and Atmospheric Administration, National Environmental Satellite, Data, and Information Service, [1985]

$P(200)$ qNO22ei NESDIS no.3

OCEANOGRAPHIC RESEARCH STATIONS--UNITED STATES.

Oceanographic data for development of the U.S. Exclusive Economic Zone. Washington, D.C. : U.S. Dept. of Commerce, National Oceanic and Atmospheric Administration, National Environmental Satellite, Data, and Information Service, 1984 .

$P(200)$ qNO22ei NESDIS no.2

OCEANOGRAPHY--BLACK SEA--ADDRESSES, ESSAYS, LECTURES.

Gidrologicheskie i geologicheskie issledovaniia Sredizemnogo i Chernogo morei. Moskva : Institut okeanologii AN SSSR, 1975.

530.2 G362g MP only

OFFSHORE OIL INDUSTRY--BERING SEA.

Tremont, John D. Resources, developmental time frames, infrastructure assumptions, and block deletion alternatives for proposed Federal lease sales in the Bering Sea and Norton Sound. [Alaska] : U.S. Dept. of the Interior, Bureau of Land Management, Alaska Outer Continental Shelf office, [1981]

$402(200)$ M662t no.1 
OFFSHORE STRUCTURES.

Design of tubular joints for offshore structures. London : UEG , 1985. 539 qD462t

OIL AND GAS LEASES--UNITED STATES.

In the national interest : federal offshore leasing. Washington, D.C. : U. S. Dept. of the Interior, Minerals Management Service, [1986?]

PAM FILE

United States. Minerals Management Service. Proposed 5-year Outer Continental Shelf Oil and Gas Leasing Program, January 1987 - December 1991 : draft environmental impact statement. [Washington, D.C.] : The service, [1986] $585.3(200)$ M662ocop

United States. Minerals Management Service. 5-year Outer Continental Shelf Oil and Gas Leasing Program for January 1987 - 1991, primary decision documents : proposed program. [Washington, D.C.] : The Service, [1986]

R $402(200)$ M662ocpdp

United States. Minerals Management Service. 5-year Outer Continental Shelf Oil and Gas Leasing Program for January 1987 - 1991, detailed decision documents : proposed program. [Washington, D.C.] : The Service, [1986]

R $402(200)$ M6620cpdd 1986

OIL FIELD BRINES--CONGRESSES.

SPE Symposium on Formation Damage Control (7th : 1986 : Lafayette, Louisiana). Proceedings: Seventh SPE Symposium on Formation Damage Control, February 2627, 1986 Lafayette, Louisiana. Lafayette, La. : The Society, ci986.

$467.4(200)$ Sol36p 1986

OIL FIELD FLOODING--MATHEMATICAL MODELS.

Chekalin, Anatolii Nikolaevich. Chisiennye resheni帒 zadach filtratsii v vodoneftianykh plastakh. \{Kazan\}: Izd-vo Kazanskogo un-ta, 1982 .

$467.4 \mathrm{C} 417 \mathrm{C}$

OIL FIELDS--PRODUCTION METHODS--CONGRESSES.

Permian Basin Oil and Gas Recovery Conference (1986 : Midland, Tex.). Proceedings : Permian Basin Oil \& Gas Reçovery Conference, March 13-14, 1986, Midiand, Texas. [Richardson, Tex.] : Society of Petroleum Engineers, C1986.

$467.4 \quad$ P423p 1986

OIL POLLUTION--AFRICA, WEST.

The Status of oil pollution and oil pollution control in the west and Central African region. Geneva, Switzerland : Regional Seas Programme Activity Centre, United Nations Environment Programme, 1982.

537.5 qun 22 no. 4

OIL POLLUTION OF THE SEA--OMAN.

Survey of tar, oil, chlorinated hydrocarbon and trace metal pollution in coastal waters of the Sultanate of Oman. Geneva, Switzerland : UNEP, 1982 .

537.5 qun22 no. 5

OIL-SHALES--ESTONIA--PERIODICALS .

Goriưchie slantsy (Tallinn, Estonia : 1984). Gorîuchie slantsy =

Oil shale. Tallin : Periodika, 1984-

$S(573) \mathrm{Ee} 7 \mathrm{~g}$ 
OIL WELL BLOWOUTS--MEXICO, GULF OF.

Investigation of October 20-27, 1983 blowout, Eugene Island Block 10, Lease OCS-G 2892 Gulf of Mexico. WWashington, D.C.I: U.S. Department of the Interior, Minerals Management Service, 1985. 402 (200) M6́620 no.85-0050

OIL WELL DRILLING--CONGRESSES.

Drilling Conference (1985: Dallas, Texas). Proceedings : Drilling Conference, February 9-12, 1986 Dallas, Texas. [S.I.] : The Society, c1986.

467.4 D832p 1986

OKLAHOMA--GEOLOGY--INDEX MAPS.

Luza, Kenneth V. Indexes to surface and subsurface geologic mapping in Oklahoma, 1977-1979. Norman : Oklahoma Geological Survey, 1983.

M (244) 20519831

OMAN--MINERAL RESOURCES.

Augé, Thierry. Mineralogic and petrographic study of basic and ultrabasic rocks of the ophiolite complex of northern oman : relationships to the chromitites ; comparison with two complexes from Saudi Arabia. [Reston, Va.] : U.S. Geological Survey, [1984]

(540) qR2dE no 65

OPTICAL MINERALOGY--HANDBOOKS, MANUALS, ETC.

Shelley, David. Optical mineralogy. 2nd ed. New York : Elsevier, Cl985.

110 Sn $44 \mathrm{~m} 1985$

ORE-DEPOSITS--ADDRESSES, ESSAYS, LECTURES.

Évolî́tesiîa osadochnogo rudoobrazovaniî̀a $v$ istorii Zemli. Moskva : Nauka, 1984 .

410 Ev64

ORE-DEPOSITS--ALTAI MOUNTAINS.

Shcherba, G. N. Metallogeni依 Rudnogo Altaîa i Kalby. Alma-Ata : Izd-vo Nauka Kazakhskoi SSR, 1984.

$410(695)$ Sh28m

ORE-DEPOSITS--CONGRESSES.

Ėksperimentalhye issledovaniîa endogennogo rudoobrazovanîa. Moskva : Nauka, 1983.

$410(570)$ Ek78i

ORE-DEPOSITS--NEVADA.

Lowe, Nathan T. Principal deposits of strategic and critical minerals in Nevada. Washington, D.C. : For sale by the Supt. of Docs., U.S. G.P.O., 1985.

402 (200) Un 34 ic no. 9035

ORE-DEPOSITS--SOVIET UNION.

Gavrilov, V. P. Kak ustroeny $i$ chem bogaty nashi nedra. Moskva : Nedra, 1981.

$403(570) \mathrm{G} 247 \mathrm{k}$

Mozgova, N. N. Bleklye rudy : osobennosti khimicheskogo sostava i svoístv. Moskva : Nauka, 1983.

$434(570)$ M877b 
ORE-DEPOSITS- -TAJIKISTAN

Rol'fiziko-meknanicheskikh svoistv gornykh porod $v$ rudolokalizaEsii : na primere Karamazara. Dushanbe : Izd-vo Donish, 1984. $410(694)$ R638f

ORE-DEPOSITS--URAL MOUNTAIN REGION--ADDRESSES, ESSAYS, LECTURES. Khimizm kolchedanonosnykh vulkanogennykh formaESii Ürala. Sverdlovsk : UNTS AN SSSR, 1982.

$410(570)$ K528

ORE-DEPOSITS--URAL MOUNTAINS--ADDRESSES, ESSAYS, LECTURES.

Mineralogicheskie issledovani endogennykh mestorozhdeni urala. Sveralovsk : UNTS AN SSSR 1982.

$410(570)$ M662i

ORES--IDENTIFICATION--TABLES.

Uytenbogaardt, W. Tables for microscopic identification of ore minerals. 2nd rev. ed., Slightly corr. New York : Dover, 1985, c1971.

116 Uy8t 1985

ORGANIC GEOCHEMISTRY.

Waples, Douglas. Geochemistry in petroleum exploration. Boston : International Human Resources Development Corp. c1985.

426.2 W1929

ORGANIC WATER POLLUTANTS--NETHERLANDS--WADDENZEE--CONGRESSES .

International Wadden Sea Symposium (4th : 1983 : Texel, The Netherlands). The role of organic matter in the wadden sea : proceedings of the $4 \mathrm{th}$ International Wadden Sea Symposium, Texel, The Netherlands, 1-3 November 1983. Texel, The Netherlands : Netherlands Institute for Sea Research, 1984 .

$S(591)$ N382p no. [E]-10

PALEOECOLOGY --ADDRESSES, ESSAYS, LECTURES

Geologie et paleoecologie des recifs. [Bern, Switzerland] : Institut de géologie de l'Université de Berne, 1984. 612 qG293

PALEOECOLOGY--SOVIET UNION.

Maksimova, S.V. Ocherki po prikladnol paleoejkologii. Moskva : Nauka, 1984

$612(570) \quad M 2880$

PALEOMAGNETISM.

Paleomagnitnye issledovanifầ donnykh i beregovykn obrazovani vnutrikontinentalhykh morei $i$ okeanov. Kiev: In-t geol. nauk AN USSR, 1983.

314 Pl74i

Storetvedt, Karsten $M$. on remagnetization and related problems in palaeomagnetism. Bergen, Norway : University of Bergen, 1969.

314 St 740

PALEOMAGNETISM--FAROE ISLANDS--ADDRESSES, ESSAYS, LECTURES .

Løvlie, Reidar. On the origin of natural remanent magnetization in some continental and oceanic rocks. Bergen, Norway : Geophysical Institute, University of Bergen, [1976]

314 qL9 480 
PALEOMAGNETISM--NEW ZEALAND.

Mumme, T. C. Paleomagnetic studies at Geophysics Division 1980-1983. Weliington, N.Z. : Geophysics Division, Department of Scientific and Industrial Research, 1985. $P(890)$ qSci2r no. 204

PALEONTOLOGY--CENOZOIC.

British Caenozoic fossils : (Tertiary and Quaternary) . 5th ed. London : The Museum, 1975. $689(510)$ B $78 \mathrm{~b} 1975$

British Caenozoic fossils (tertiary and quaternary). 3d ed. London : The Museum, 1968 $689(510)$ B 18 b 1968

British Caenozoic fossils (Tertiary and Quarternary). 2d ed. London : Printed by order of the Trustees of the British Museum, 1963. $689(510)$ B $78 \mathrm{~b} 1963 \mathrm{MP}$

PALEONTOLOGY--COLLECTED WORKS.

Palaios. Palaios. Tulsa, Okla. : The Society, 1986602 (244) P172

PALEONTOLOGY--HISTORY .

Rudwick, Martin J. $\dot{S}$. The meaning of fossils : episodes in the history of palaeontology. 2nd ed. Chicago : University of Chicago press, 1985. $609 \mathrm{R} 837 \mathrm{~m} 1985$

PALEONTOLOGY--MESOZOIC.

Biostratigafiia mezozoîa zapadnoì Sibiri : utochnenie stratigraficheskoi skhemy. Moskva : Nauka, 1985. $688(690.2) \quad$ B524

PALEONTOLOGY-PALEOZOIC.

British Palaeozoic fossils. 4th ed. London : The Museum, 1975, repr. 1983.

$682(510)$ B 68 D 1975

PALYNOLOGY--NORTH ATLANTIC OCEAN.

Turon, Jean-Louis. Le palynoplancton dans l'environnement actuel de $I^{\prime}$ Atlantique nord-oriental : evolution climatique et hydrologique depuis le dernier maximum glaciaire. Talence, France : Université de Bordeaux, 1984 .

G (540) qB64ugm no 17

PEAT--MAINE--ANDROSCOGGIN COUNTY--MAPS.

Lepage, Carolyn A. Maine peat resource evaluation, Androscoggin, Cumberland, and York Counties. Augusta : Maine Geological Survey, Maine Office of Energy Resources, 1983. $M(211) 464$ An 281

PEAT--MAINE--AROOSTOOK COUNTY--MAPS.

Lepage, Carolyn A. Maine peat resource evaluation, Aroostook County. Augusta : Maine Geological Survey, 1982.

M (2II) 464 Ar671 

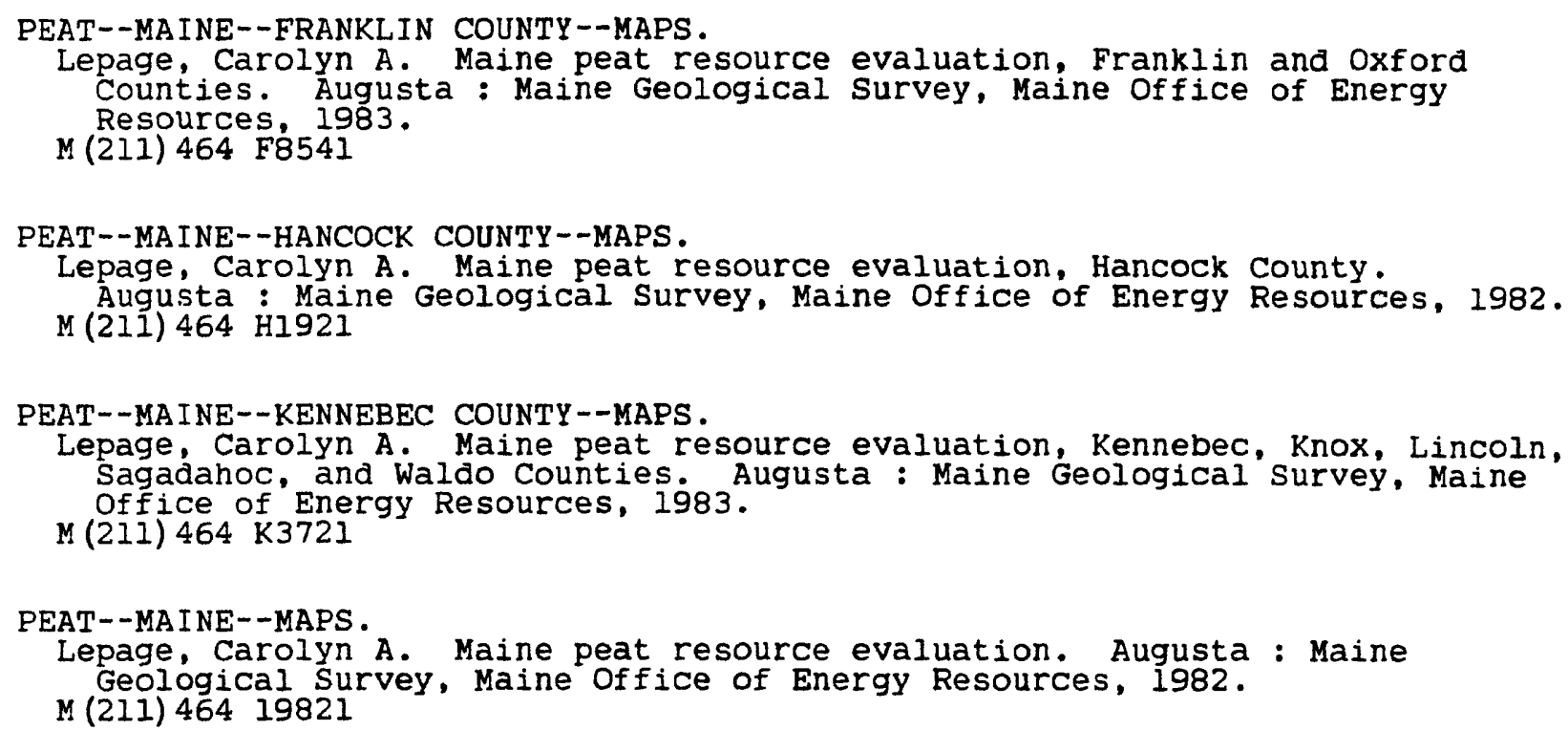

PEAT--MAINE--PENOBSCOT COUNTY--MAPS.

Lepage, Carolyn A. Maine peat resource evaluation, Penobscot County. Augusta : Maine Geological Survey. Maine Office of Energy Resources, 1982. M (2II) 464 P386I

PEAT--MAINE--PISCATAQU IS COUNTY--MAPS.

Lepage, Carolyn A. Maine peat resource evaluation, Piscataquis County.

Augusta : Maine Geological Survey, Maine Office of Energy Resources, 1982. M (211) 464 P 6731

PEAT--MAINE--SOMERSET COUNTY--MAPS.

Lepage, Carolyn A. Maine peat resource evaluation, Somerset County.

Augusta : Maine Geological Survey, Maine Office of Energy Resources, 1982. M (21I) 464 So54I

PEAT--MAINE--WASHINGTON COUNTY--MAPS.

Lepage, Carolyn A. Maine peat resource evaluation, Washington County.

Augusta : Maine Geological Survey, Maine Office of Energy Resources, 1982. M (21I) 464 W276I

PEGMATITES

Ivanov, A. N. Évolîû́îia pegmatitoobrazovaniîa v regionakh $s$ mnogoétapnym granitoidnym magmatizmom. Novosibirsk : Nauka, Sibirskoe otd-nie, 1983.

170 IV 2 e

PERU--MINERAL RESOURCES.

Inventario nacional de sustancias no metalicas. Lima, Peru : Direccion General de Geologia, Direccion de Geologia Minera, 1982.

(450) $\mathrm{qP} 43 i$

PETROLEUM--GEOLOGY--DEAD SEA REGION, ISRAEL AND JORDAN.

Sokolin, Haim. Oil prospection in the Dead Sea graben : (analysis of past investigations and recommendations for further exploration). Jerusalem : Ministry of Energy and Infrastructure, Geological Survey of Israel, Oil Research Division, 1980.

(681) Is $7 \mathrm{r}$ no. OD/1/80 
PETROLEUM--GEOLOGY --FIELD WORK.

Field geologist's training guide. Boston : International Human Resources Development Corp., cl985.

$467.4 \quad F 455$

PETROLEUM--GEOLOGY--MATHEMATICAL MODELS.

Kirshin, A. V. Modelirovanie proEsessov preobrazovanifâ organicheskogo veshchestva $v$ litogeneze $i$ geneticheskie predposylki neftegazonosnosti nedr. Tashkent : Izd-vo Fan Uzbekskoi SSR, 1984.

$467 \mathrm{~K} 638 \mathrm{~m}$

PETROLEUM--GEOLOGY--SIBERIA--ADDRESSES, ESSAYS, LECTURES.

Metody prognozirovaniia i zakonomernosti razmeshcheniià litologicheskikh i stratigraficheskikh lovushek nefti i gaza : sbornik nauchnykh trudov. Leningrad : VNIGRI, 1983.

$467(690)$ M567p

PETROLEUM--GEOLOGY--SOUTH CHINA SEA--CONGRESSES.

Workshop on the Geology and Hydrocarbon Potential of the South China sea and Possibilities of Joint Development (2nd : 1983 : Honolulu, Hawaii). Geology and hydrocarbon potential of the South China sea and possibilities of Joint Development : proceedings of the Second EAPI/CCOP Workshop EastWest Center, Honolulu, Hawaii 22-26 August 1983. New York ; Oxford : Pergamon Press, [1985]

580 En213 v. 10 no. 3-4

PETROLEUM--GEOLOGY--SOVIET FAR EAST.

Ivanov, Valerii Vladimirovich. Osadochnye baseiny Severo-VostochnoI Azii: sravnitelhyí neftegeologicheskil analiz. Moskva : Nauka, 1985.

467 (691) IV20

PETROLEUM--GEOLOGY--SOVIET UNION.

Diîashev, Rasim Nagimovich. Sovmestnaîa razrabotka neftîanykh plastov. Moskva : Nedra, 1984. $467(570)$ D $538 s$

Dobycha tîazhelykh i vysokovîazkikh neftĕ. Moskva : Nedra, 1985. $467(570)$ D656

Geologo-ekonomicheskaîa ofsenka prognoznykh resursov nefti i gaza. Leningrad: VNIGRI, 1983.

$467(570)$ G2920

PETROLEUM--GEOLOGY --THAILAND--CONGRESSES.

Mahawithayalai Chiang Mai. Dept. of Geological Sciences. Technical Meeting (1982 : Chiang Mai University, Chiang Mai, Thailand). Proceedings of the annual Technical Meeting, 1982 : 1-2 February 1983. Chiang Mai. Thailand : Dept. Of Geological Sciences, Chiang Mai University, 1983.

$G(635)$ C43s no.4

PETROLEUM IN SUBMERGED LANDS--ALASKA--ST. GEORGE BASIN .

Geological and operational summary. St. George Basin COST no. 2 well, Bering Sea, Alaska. TWashington D.C.?\}' : U.S. Dept. of Interior, Minerals Management Service, [1984]

$402(200)$ M6620 no.84-0018 
PETROLEUM INDUSTRY--AFRICA, WEST .

Onshore impact of off shore oil and natural gas development in the west and Central African region. Geneva, Switzerland : UNEP, 1984. 537.5 qun 22 no. 33

PETROLEUM INDUSTRY AND TRADE--ENVIRONMENTAL ASPECTS--MEXICO, GULF OF.

Gusey, William F. Petroleum production and $\mathrm{f} i \mathrm{sh}$ and wildifie resources : the Gulf of Mexico. New York : Shell Oil Co., Environmental Conservation Dept. [1973?].

$585.3(062)$ G972

PETROLEUM--MIGRATION.

Chakhmakhchev, V. A. Geokhimi îa proEsessa migraEsii uglevodorodnykh sistem. Moskva : Nedra, 1983.

$426.2(570)$ C 3489

PETROLEUM--OKLAHOMA--MAPS.

Burchfield, Margaret R. Map of Oklahoma oil and gas fields. Norman, Okla. : Oklahoma Geological Survey, 1985.

M (244) $4671985 \mathrm{~b}$

PHYSICAL GEOGRAPHY--TEXT-BOOKS.

Makunina, A. A. Fizicheskaî̀ geografî̃a SSSR. [Moskva] : Izd-vo Moskovskogo un-ta, 1985.

503 M288f

PLACER DEPOSITS--SAYAN MOUNTAINS.

Osadchii, Stepan Stepanovich. Uslovi ia rossypeobrazovanitia v

Vostochnom Saíane. Novosibirsk : Nauka, Sibirskoe otd-nie, 1984.

$414(690)$ Os22u

PLANETARY RINGS.

Elliot, James. Rings : discoveries from Galileo to Voyager. Cambridge, Mass. : MIT Press, c1984.

735 El58r F only

POLAND--GEOLOGY--TATRA MOUNTAINS.

Jurassic and Cretaceous lithostratigraphic units of the Tatra Mountains = Jurajkie i kredowe jednostki litostratygraficzne tatr. Warszawa : Wydawnictwa Geologiczne, 1985.

(578) P74sg v.84

POTASSIUM-ARGON DATING--MAPS.

potassium-argon and fission-track ages of the Sonoma volcanics in an area north of San Pablo Bay, California. Reston, Va. : U.S. Geological Survey, 1985.

POTOMAC RIVER.

Wolman, Markley Gordon. An analysis of physical characteristics of the Potomac River which affect its navigability. Baltimore, Ma. : Dept. of Geography and Environmental Engineering, The Johns Hopkins University, [1975] $552(225)$ R298pts

POWER RESOURCES--AFRICA, SOUTHERN--COLLECTED WORKS .

Energy, environment and development in Africa. Energy, environment and development in Africa. Stockholm : Beijer Institute, Royal Swedish Academy of Sciences, 1984-

$S(700)$ En27 
POWER RESOURCES--CHINA--ABSTRACTS.

China report. Economic affairs, energy: status and development. China report. Economic affairs, energy: status and development. Springfield, Va.; Washington, D.C. : NTIS : USGPO.

$\mathrm{S}(610) \mathrm{C} 442 \mathrm{cr}$

POWER RESOURCES--ECONOMIC ASPECTS--EAST ASIA.

Yager, Joseph A. The energy balance in Northeast Asia. Washington, D.C. : Brookings Institution, c1984.

$580(611)$ Y $12 e$

POWER RESOURCES--INDONESIA--MAPS.

Ikatan AhIi Geologi Indonesia. Peta sumberdaya energi Indonesia.

Bandung, Indonesia : Ikatan AnIi Geologi Indonesia, 1980.

$M(910) 581980 i$

POWER RESOURCES--NEW YORK (STATE) --COLLECTED WORKS

ERDA report (New York State Energy Research and Development Authority). ERDA report. Albany, N.Y.: The Authority, 1980-

$P(221)$ En27e

PRECIOUS METALS--METALLURGY--CONGRESSES.

Precious metals recovery from low-grade resources : proceedings : Bureau of Mines open industry briefing session at the National Western Mining

Conference, Denver, CO, February 12, 1986. Pgh. [i.e., Pittsburgh] Pa. : U.S. Dept. of the Interior, Bureau of Mines, 1985 .

$402(200)$ Un 34 ic no.9059

PRECIPITATION (METEOROLOGY) --ANALYSIS

Brooks, Myron H. Interlaboratory comparability, bias, and precision for four laboratories measuring constituents in precipitation, November 1982August 1983. Lakewood, Colo. : U.S. Geological Survey, 1985.

(200) WRi no.85-4313 D MP

PROJECT ASHLIFT.

Washington (State). Office of Environmental Health Programs. Project

Ashlift : a Mount Saint Helens disaster assistance and crisis counseling program ; final report. [S.I.] : The Division, [198I] $240(284)$ W2 $78 \mathrm{pf}$

PROSPECTING--MATHEMATICAL MODELS.

Crovelii, Robert A. A comparison of analytic and simulation methods for petroleum play analysis and aggregation. [Denver, CO] : U.S. Geologica] Survey, 1986.

(200) R29o no.86-97 D MP

PROSPECT ING- - TURKMEN ISTAN--KARA-KUM

Khodzhakuliev, IA. A. Paleogidrogeologicheskie issledovani 1 a pri poiskakh nefti i gaza. Moskva : Nedra, 1985.

$426(695.3)$ K528p

QUARTZ.

DeliÉsin, I. S. Strukturoobrazovanie kvarEsevykh porod. Moskva : Nauka, 1985 .

170 D378s 
QUARTZITE--NEVADA.

Lee, Donald Edward. The oxygen isotope composition of selected quartzites of White Pine County, Nevada, and nearby areas. [Denver, CO] : U.S. Geological Survey, 1986.

(200) R290 no.86-38 D MP

QUEBEC (PROVINCE) --GEOLOGY--CHIBOUGAMAU REGION--CONGRESSES.

Chibougamau, stratigraphy and mineralization : proceedings of the chibougamau symposium and field trip. Montreal, Quebec : Canadian Institute of Mining and Metallurgy, cl984.

$201(140)$ qC428

QUEENSLAND--MINERAL RESOURCES--NAMBOUR REGION.

Martin, J.E. Industrial rock and mineral resources of the Nambour and Caloundra 1:100 000 sheet areas. Brisbane : Geological Survey of Queensland, 1985 .

(810) qD no.385

RADAR IN EARTH SCIENCES.

Jet Propulsion Laboratory (U.S.). Science requirements for free-flying imaging radar (FIREX) experiment : for sea ice, renewable resources, nonrenewable resources, and oceanography. Pasadena, California: The Laboratory, [1982]

753.7 J512s

RADIOACTIVE DATING.

Dalrymple, G. Brent. Radiometric dating, geologic time, and the age of the Earth : a reply to "scientific" creationism. [Menlo Park, Calif.] : U.S. Geological survey, [1986]

(200) R290 no.86-110 D MP

RADIOACTIVE POLLUTION--ENVIRONMENTAL ASPECTS--OCEANIA.

Radioactivity in the South Pacific. Geneva, Switzerland : Regional Seas Programme Activity Centre, United Nations Environment Programme, 1984. 537.5 qun22 no. 40

RADIOACTIVE WASTE DISPOSAL IN THE GROUND.

Savage, David. Granite-water interactions at 100 ipo isC, $50 \mathrm{MPa}:$ an experimental study. Keyworth, Eng.: British Geological Survey, [1984]

(510) qR298 FLPU no.84-2

RADIOACTIVE WASTE DISPOSAL IN THE GROUND--EUROPE.

Christofi, N. The geomicrobiology of European mines relevant to radioactive waste disposal. Keyworth, England: British Geological Survey, 1985.

(510) qR298 FLPU no.85-1

RADIOACTIVE WASTE DISPOSAL IN THE GROUND--GREAT BRITAIN.

The Geomicrobiology of used and disused mines in Britain. Keyworth, England : British Geological Survey, 1984.

(510) qR298 FLPU no.84-5

RADIOACTIVE WASTE DISPOSAL IN THE GROUND--UTAH.

Daniels, Jeffrey J. Analysis of borehole geophysical data in an evaporite sequence at salt Valley, Utah. [Denver, co]: U.S. Geological Survey, [1980]

(200) R290 no.80-525 D MP 
RADIOLARIA, FOSSIL.

Schaaf, André. Les radiolaires du Crétacé intérieur et moyen :

biológie et systematique. Strasbourg : Université Louis Pasteur de

Strasbourg, Institut de géologie, 1984.

$G(540)$ St82m no 75

RARE EARTH METALS.

Podporina, E. K. Redkozemelhye ellementy $v$ korakh vyvetrivani iâ. Moskva : Nauka, 1985.

$439(570)$ P752r

RECREATION AREAS--OREGON--MAPS .

United States. Bureau of Land Management, Oregon State Office. Western

oregon special management areas, December 1985. Portland, or. : The

Office, 1985 .

M (285) 585.7 W524u

RECYCLING (WASTE, ETC.)--UNITED STATES.

Stanczyk, Martin H. Resource recovery from municipal solid waste. [Washington, D.C.?] : U.S. Bureau of Mines, [1985]

$402(200)$ Un $34 b$ no.683

REGIONAL SEAS PROGRAMME (UNITED NATIONS ENVIRONMENT PROGRAMME) .

United Nations Environment Programme. Achievements and planned development of UNEP's Regional Seas programme and comparable programmes sponsored by other bodies. Geneva, Switzerland : UNEP, 1982.

537.5 qun22 no.1

REMOTE SENSING--EOUIPMENT AND SUPPLIES.

Chen, $H_{j}$ S. Space remote sensing systems : an introduction. orlando [Fia.j : Academic Press, 1985.

753.7 C422s F only

REMOTE SENSING--GEOLOGY, STRUCTURAL.

Struktury kontinentalhoi i perekhodnoì zemnoì kory na kosmicheskikh snimkakh. Moskva : Nedra, 1984.

753.7 St88

REMOTE SENSING--MONTANA--MAPS.

James, Harold Lloyd. Sateli ite photomap of the Northern Rocky Mountains and Great Plains, Montana, Wyoming and adjacent areas. [Butte, Mont.] : Montana Bureau of Mines and Geology, 1983.

$M(280) 5.11983 j$

REMOTE SENSING--OCEANOGRAPHY.

Everdale, Fred. Satellite oceanography : NOAA-n advanced very high resolution radiometer digital data. Washington, DC: National Oceanic and Atmospheric Administration, [1985]

$P(200)$ NO22esm

Seasat Data Utilization Project report. Pasadena, Calif. : National Aeronautics and Space Administration : Jet Propulsion Laboratory, California Institute of Technology, 1982 .

753.7 Sel7d

REMOTE SENSING--OCEANOGRAPHY--CONGRESSES .

Nekontaktnye metody izmereni ia okeanograficheskikh parametrov : sbornik

dokladov 4-go Vsesoiuznogo seminara, odessa, 21-25 dekabría $1981 \mathrm{~g}$.

Moskva : Moskovskoe otd-nie Gidrometeoizdata, 1983.

$530.02 N 318$ 
REMOTE SENSING--PROSPECTING--SOVIET UNION--ADDRESSES, ESSAYS, LECTURES. Prognoz lokalhykh struktur po aerokosmicheskim materialam : sbornik nauchnykh trudov. Moskva : VNIGNI, 1984.

$467(570)$ M845t vyp. 252

RESEARCH--ALASKA--CONGRESSES.

Alaska Science Conference (34th : 1983 : Whitehorse, Yukon). Alaska/Canada North: neighbours in science : proceedings of the 34th Alaska Science Conference, 28 september - 1 October 1983, Whitehorse, Yukon. IFairbanks, Alaska] : Arctic Division, American Association for the Advancement of Science with assistance from the Northern Program, Department of Indian and Northern Affairs, Ottawa, ontario, [1983]

031 (286) Allis no.34 D MP

RESEARCH, INDUSTRIAL--UNITED STATES--DIRECTORIES.

Directory of American research and technology. New York : R.R. Bowker., cl986-

R $056(200)$ In 25

RHEOLOGY - -PERIODICALS.

Cahiers du Groupe français de rhéologie. Cahiers du Groupe français de rhéologie. Paris: La Groupe.

$\mathrm{S}(540)$ qCil8

RIFTS (GEOLOGY) .

Richter, Dieter. Die [Delta]-Achsen und inre räumlich-geometrischen Beziehungen zu Faltenbau und Schiefrigkeit. Koln und Opladen : Westdeutscher Verlag, 1963.

276 R418d

RIFTS (GEOLOGY) --RED SEA--ATLASES.

Atlas podvodnykh fotografil Krasnomorskogo rifta. Moskva : Nauka, 1983. $276(072)$ At 65

RIVER SEDIMENTS--BAIKAL LAKE REGION.

Vlasova, L. K. Rechnye nanosy basseina ozera Baĭkal. Novosibirsk : Nauka, Sibirskoe otd-nie, 1983.

213 v845r

RIVERS. Morisawa, Marie. Rivers : form and process. London : New York : Longman,
1985 .

552 M826r

RIVERS--ARKANSAS--MAPS.

Hunrichs, R. A. Identificiation and classification of perennial streams of Arkansas. [Little Rock, Ark.] : U.S. Geological Survey, 1983. $M(241) 552$ i $983 \mathrm{~h}$

RIVERS--POLLUTION--MATHEMATICAL MODELS.

Bird, Sandra lee. An evaluation of a two-dimensional model for transport of a slug release in a meandering channel. Austin, Tex. : Center for

Research in Water Resources, University of Texas at Austin, [1985]

$\mathrm{S}(245)$ Un 3 trc no.207

ROCK DEFORMATION--MOROCCO--ANTI-ATLAS MOUNTAINS.

Heinitz, Werner. Die Deformation des sedimentaren Deckgebirges im zentralen Anti-Atlas (Sudmarokko). Berlin : D. Reimer, 1984.

G (530) qB455ga Bd.55 
ROCK SALT.

Fiveg, Mikhail Pavlovich. Kak obrazuîutsîa zalezhi kamennoi i kaliinykh solei. Novosibirsk : Izd-vo Nauka, Sibirskoe otd-nie, 1983. 444 F586k

ROCKS--ANALYSIS.

Danielsson, Ringa. Chemical analysis of USGS-W-2, USGS-DNC-I and USGS-BIRI standara rocks. Espoo [Finland]: Geologian tutkimuskeskus, 1985. (579) qRi no.70

ROCKS, CARBONATE--UZBEKISTAN .

Babaev, Ashot Grigorévich. Karbonatnaîa formaEsi îa iurskogo vozrasta platformennoi oblasti Uzbekistana i ee neftegazonosnost. Tashkent : Izd-vo Fan Uzbekskoi SSR, 1983. $180(696)$ Bli2k

ROCKS, IGNEOUS--ADDRESSES, ESSAYS, LECTURES

Korreliatsiià magmaticheskikh porod Chekhoslovakii i nekotorykh raionov SSSR. Moskva : Nauka, 1983. $170 \mathrm{~K} 843$

ROCKS, IGNEOUS--ALASKA.

Hunt, susan J. Structural analysis of plutonic and metamorphic rocks in an area east of Wrangell, Alaska. [Menlo Park, CA] : U.S. Geological survey, [1986]

(200) R290 no.86-50 D MP

ROCKS, IGNEOUS--CLASSIFICATION

Shteinberg, Dmitrii Sergeevich. O klassifikatsii magmatitov. Moskva : Nauka, 1985.

170 sh880

ROCKS, IGNEOUS--OCEANICA.

Berger, Emmanuel T. Enclaves ultramafiques, mégacristaux et leurs basaites-hôtes en contexte océanique (Pacifique sud) et continental (Massif Central français). [Paris?] : Université de Paris-sud, Centre d' orsay, [1981?] $170 \mathrm{~B} 453 \mathrm{e}$

ROCKS, SEDIMENTARY--BALTIC SEA REGION--ADDRESSES, ESSAYS, LECTURES.

Terrigennye mineraly osadochnykh porod Pribaltiki. Tailin : Akademiia nauk Estonskoi SSR, In-t geologii, 1983. $180(576)$ T278m

ROCKS, SEDIMENTARY - -HIMALAYA MOUNTAINS--ADDRESSES, ESSAYS, LECTURES. Sedimentary geology of the Himalaya. New Delni : Today \& Tomorrows Publishers and Printers, 1984. $180(640)$ qSe28

ROCKS, SEDIMENTARY - -SIKHOTE ALIN MOUNTAINS.

Markevich, P. V. Geosinklinaltoe terrigennoe osadkonakoplenie na vostoke Azii $v$ fanerozoe : na primere Sikhote-Alinia i Kamchatki. Moskva : Nauka, 1985.

$180(691) \quad M 3429$

ROCKS, SEDIMENTARY--THIAN SHAN MOUNTTAINS.

Shvanov, V. N. Litoformatsionnye korrelî̉̂Esii terrigennykh i

metamorficheskikh tolshch : IUzhnyi Tian-Shan. Leningrad : Izd-vo Leningradskogo universiteta, 1983.

$180(690)$ Sh961 
ROCKS, SEDIMENTARY--UKRAINE.

Semenenko, N. P. Geoknimiia osadochno-vulkanogennykh formaEs̀i

Ukrainskogo shchita : Esentralfaîa chast. Kiev : Nauk. dumka, 1985. 298 (571) Se52g

RUNOFF.

Nakamura, Eiichi. Factors affecting the removal rate of street surface contaminants by overland flow. [Tokyo]: Public Works Research Institute, Ministry of Construction, [1984]

$P(620)$ P96j V.24

RWANDA.

Rwanda, a country study. Washington, D.C. : for sale by the Supt. of Docs., U.S. G.P.O., c1982.

$504(771)$ R 952

SAINT HELENS, MOUNT., WASH.--MAPS, PHYSICAL.

Alpha, Tau Rho. Physiographic diagrams of Mount St. Helens, Washington, showing changes in its summit crater, 1983. Reston, Va. : U.S. Geological Survey, 1985 .

M (284) 54 M863a 1985 -- M(200) 4 vUn3mf no.1771 - M (200) MF no.1771

SALINE WATER CONVERSION--COLORADO--MESA COUNTY.

Colorado River Basin salinity control project : draft enyironmental impact statement, Grand valley unit, stage two development. [Salt Lake city]: The Bureau, 1985.

$585.3(271)$ Un 36 cd

SANITARY LANDFILLS--ENGLAND--BANBURY REGION.

Alexander, L. S. A case study of a landfill in a shallow limestone aquifer, near Banbury, Oxfordshire. Keyworth, England : British Geological Survey, [1984]

(510) qR298 FLPU no.84-10

SAUDI ARABIA--GEOLOGY.

Kellogg, Karl S. Reconnaissance geology of the Haíl quadrangle, sheet $27 /$ 4IB, Kingdom of Saudi Arabia. [Reston, VAl: U.S. Geological'survey, 1985. (200) R290 no.85-6I8 D MP

SAUDI ARABIA--MINERAL RESOURCES.

Staatz, Mortimer Hay. Trace- and minor-element mineralogy of the microgranite at Ghurayyah, Kingdom of Saudi Arabia. [Reston, VA] : U.S. Geological Survey, 1986.

(200) R290 no.86-105 D MP

SCIENCE--CAUCASUS--PERIODICALS.

Izvestiia severo-Kavkazskogo nauchnogo Esentra vysshei shkoly.

Estestvennye nauki. Izvesti iầ Severo-Kavkazskogo nauchnogo țentra

vysshei shkoly. Estestvennye nauki. Rostrov-na-Dony, Soviet Union : Izdvo. Rostovskogo universiteta, 1973-

$S(570)$ qI28

SCIENCE--PERIODICA̧LS.

Pei-ching ta hsueh hsüeh pao. Tzu jan ko hsüeh pao. Pei-ching : Peiching ta hiveh cho pan she.

$s(610)$ P348t 
SCIENCE--PH ILOSOPHY--CONGRESSES .

Science and creation : geological, theological, and educational perspectives. New York : Macmillan, cl986. $030 \mathrm{Sci} 27 \mathrm{C}$

SCIENCE--SOCIETIES, ETC.--COLLECTED WORKS .

Atti della Accademia di scienze, lettere e arti di Palermo. Serie quinta, Parte prima: Scienze. Palermo : dell'Accademia, 1982-

$S(550)$ qPI7 Ser. 5

SCOTLAND--GEOLOGY--MULL ISLAND.

Isle of Mull, Inner Hebrides, Scotland: field guide. Cambridge [England]: Quaternary Research Association, cl985.

$209.1(512)$ Is $4 \mathrm{f}$

SEDIMENT CONTROL- -WASHINGTON (STATE) .

United States. Office of the Assistant Secretary of the Army (Civil Works). Mount St. Helens sediment control, Washington (Toutle, Cowlitz, and Columbia Rivers) : communication from the Assistant Secretary of the Army (Civil Works) transmitting a report and supplemental report of the Chief of Engineers ... conducted under the authority of section 216 of the flood Control Act of 1970. Washington : U.S. G.P.O., 1985 [i.e. 1986]

$P(200)$ DAIO2Cm

SEDIMENTATION AND DEPOSITION--HURON, LAKE.

Robbins. John A. Sediments of Saginaw Bay, Lake Huron : elemental composition and accumulation rates. Duluth, Minn. : Environmental Research Laboratory--Duluth office of Research and Development, U.S. Environmental Protection Agency ; 1986.

554 (255) R536s

SEDIMENTATION AND DEPOSITION--IOWA.

Odgaard, A. Jacob. Bank erosion contribution to stream sediment load.

Iowa City, Iowa : Iowa Institute of Hydraulic Research, the University of Iowa, [1984]

$S(262)$ qun $35 \mathrm{r}$ no.280

SEDIMENTS (GEOLOGY)--MAINE--AROOSTOOK COUNTY--MAPS.

Lowell, Thomas. Evaluation of the mineral potential, Upper st. John River Valley, Aroostook County, Maine : Appendix D, Reconnaissance surficial geology northwest of the St. John River between Allagash, Maine, and St. Pamphile, Quebec. Augusta : Maine Geological Survey, 1980. $M(211) 213$ UpEI

SEDIMENTS (GEOLOGY) --MAINE--FREEPORT QUADRANGLE--MAPS .

Smith, Geoffrey W. Reconnaissance surficial geology map of Freeport, Maine. Augusta, Me. : Bureau of Geology, Dept. Of Conservation, 1977.

$M(211) 213$ F878s

SEDIMENTS (GEOLOGY)--MAINE--MAPS.

Thompson, Woodrow B. Surficial geologic map of Maine. Augusta : Maine Geological Survey, 1984 .

$M$ (211) $2131984 t$

SEDIMENTS (GEOLOGY)--MAINE--MT. KATAHDIN--MAPS.

Davis, Philip Thompson. Surficial geologic map of Mt. Katahdin. Augusta : Maine Geological Survey, 1976.

$M(211) 213$ M864a 
SEDIMENTS (GEOLOGY) --MAINE--WINTERVILLE QUADRANGLE--MAPS .

Genes, Andrew N. Reconnaissance surficial geology of the Winterville quadrangle, Maine. Augusta, Me. : Maine Geological survey, 1981. $M(211) 213$ sq $W 736 \mathrm{~g}$

SEEPAGE--MATHEMATICAL MODELS.

Franciss, F. O. Soil \& rock hydraulics : fundamentals, numerical methods $\varepsilon$ techniques of electrical analogs. Rotterdam ; Boston : A.A. Balkema, 1985. 778 F847s

SEISMIC PROFILING--MINNESOTA--RAMSEY COUNTY.

Woodward, D. G. Seismic-refraction study of suspected drift-filled bedrock valleys in Ramsey County, Minnesota. St. Paul, Minn. : U.S. Geological Survey, 1985.

(200) WRi no.85-4107 D MP

SEISMIC PROSPECTING.

Brown, L. F. Notes to accompany lectures on facies analysis and its role in seismic stratigraphic interpretation. [Australia] : Petroleum Exploration Society of Australia, 1985. 426.3 qB814f

SEISMIC PROSPECTING--EQUIPMENT AND SUPPLIES.

Sistemy registratsii $i$ obrabotki dannykh seismorazvedki. Moskva : Nedra, 1984 .

426.3 Si 84

SEISMIC WAVES--ABSTRACTS.

Gregersen, Søren. Regional inhomogeneities in the earth's crust and upper mantle detected with seismic waves, with emphasis on the surface wave amplitudes. København, Danmark : Geodaetisk Institut, 1985.

$S(585)$ D41md no.57

SEISMOLOGY --ADDRESSES, ESSAYS, LECTURES,

Makroseismicheskie $i$ instrumentalhye issledovani îa silhykh zemletriasenii. Moskva : Nauka, 1985.

G (570) V894 vyp.26

SEISMOLOGY - -ARMENIA.

Gabrieliân, A. A. Seismotektonika Armiânskoí SSR. Erevan : Izd-vo Erevanskogo un-ta, 1981.

$240(572)$ GII4s

SEISMOLOGY --UNITED STATES.

Crumlish, Joseph D. A preliminary study of engineering seismology benefits. Washington, D.C. U.S. G. P. O. [1967]

$\mathrm{P}(200) \mathrm{Cl} 4 \mathrm{P}$

SEISMOMETRY.

Shapira, Avi. Employment of a magnitude duration relation to determine local magnitudes. Holon, Israel : The Institute, 1982.

$240 \operatorname{sn} 22 \mathrm{e}$

SELLI, RAIMONDO--ADDRESSES, ESSAYS, LECTURES .

Geological evolution of the Mediterranean Basin : Raimondo Selli commemorative volume. New York : Springer-Veriag, c1985. $210(059) \mathrm{G} 293$ 
SEWAGE--PURIFICATION--BIOLOGICAL TREATMENT--MATHEMATICAL MODELS .

Mathematical models in biological waste water treatment. Amsterdam ; New York : Elsevier, 1985.

$\mathrm{S}(591) \mathrm{D} 493 \mathrm{no.7}$

SHENANDOAH RIVER, VA. AND W. VA.

Wolman, Markley Gordon. An analysis of the physical characteristics of the Shenandoah River which affect its navigability. Baltimore, Md.: Dept. of Geography and Environmental Engineering, The Johns Hopkins University, [1975] 552 (227) R298sts

SILICATES.

Liebau, Friedrich. Structural chemistry of silicates : structure, bonding, and classification. Berlin; New York : Springer-Verlag, 1985.

126.2 L622S

SILIÇON--ELECTRIC PROPERTIES.

Zainabidinov, Sirazhiddin. Fizicheskie osnovy obrazovanifia glubokikh urovnei v kremnii. Tashkent : Izd-vo Fan Uzbekskoi SSR, 1984.

$848.5 \mathrm{Z} 13 \mathrm{~s}$

SILVER--UNITED STATES.

United States. Congress. House. Committee on Interior and Insular Affairs. Subcommittee on Mines and Mining. Silver, production and availability : hearings before the Subcommittee on Mines and Mining of the Committee on Interior and Insular Affairs, House of Representatives, Eighty-ninth Congress, first session : inquiry to develop factual data relative to the availability of silver and the nation's capacity to produce silver for the foreseeable future, June 7, 8, 9, 1965. Washington : U.S. G.P.0., 1965.

$P(200)$ C $725 \mathrm{~m} 6 \mathrm{~s} 1965$

SINKHOLES--FLORIDA.

Church, Ronald $\mathrm{H}$. Evaluation of a ground penetrating radar system for detecting subsurface anomalies. Pittsburgh, Pa. : U.S. Dept. of the Interior, Bureau of Mines, 1986.

$402(200)$ Un34ex no.9004

SOCIETY OF ECONOMIC PALEONTOLOGISTS AND MINERALOGISTS.

Society of Economic Paleontologists and Mineralogists. Midyear Meeting. Abstracts. Tulsa, Okla. : The Society, cl984-

$G(200)$ Sol $3 a$

SOIL CONSERVATION.

Guidelines for the control of soil degradation. Rome : United Nations Environment Programme : Food and Agriculture organization of the United Nations, 1983.

941 qG942

SOIL ECOLOGY.

Microfloral and faunal interactions in natural and agro-ecosystems. Dordrecht ; Boston : M. Nijhoff/Dr. W. Junk, 1986.

$298.3 \mathrm{D} 492 \mathrm{v} \cdot[3]$

SOIL MECHANICS--CONGRESSES.

Sol et sous-sol et sécurité des constructions. [Paris] : Bureau de recherches géologiques et minieres, 1973-1974.

(540) qSo 42 
Vibration problems in geotechnical engineering : proceedings of a symposium. New York : American Society of Civil Engineers, 1985. 768.1 V658

SOIL MICROMORPHOLOGY--CONGRESSES.

Soil micromorphology and soil classification : proceedings of a symposium. Madison, Wis.: SSSA, 1985.

$941(200)$ So3sp no.15

SOIL SCIENCE--COLLECTED WORKS.

Advances in soil science (New York, N.Y.). Advances in soil science. New York : Springer-Verlag, cl985941 Ad95sn

SOIL-SURVEYS--MICHIGAN--MISSAUKEE COUNTY

Frederick, William E. Soil survey of Missaukee County, Michigan. 941 [Washington, D.C.] : The service, [1985]

SOIL-SURVEYS--NEBRASKA--NEMAHA COUNTY--MAPS.

Kerl, Donald E. Soil survey of Nemaha County, Nebraska. (Washington, $D$. C.?]: The Service, 1985.

$941(200)$ Un 34 N2 Nemaha County

SOIL-SURVEYS--VIRGINIA--MIDDLESEX COUNTY .

Soil survey of Middlesex County, Virginia. [Washington, D.C.?] : The Service, 1985 .

$941(200)$ Un34V8 Middlesex County

SOIL-SURVEYS--VIRGINIA--VIRGINIA BEACH.

Hatch, Danny R. Soil survey of City of Virginia Beach, Virginia. 941 [Washington, D.C.] : The Service, [1985]

SOILS--BRITISH COLUMBIA--LARDEAU REGION .

Wittneben, U. Soil resources of the Lardeau map area (82K). Kelowna : Ministry of Environment, 1980.

$P(180)$ En88rr no.15

SOILS--BRITISH COLUMBIA--MANSON RIVER REGION.

Epp, P. F. Soils of the Manson River-Fort Fraser map area. Victoria, B. C. : Ministry of Environment, [1983]

$P(180)$ En88m no.1

SOILS--BRITISH COLUMBIA--SEYMOUR ARM REGION.

Kowall, R. C. Soil and terrain of the Seymour Arm area. Kelowna :

Ministry of Environment, Resource Analysis Branch, [1980]

$P(180)$ En88rr no. 19

SOILS--GEORGIA--WASHINGTON COUNTY.

Smith, Ernest H. Soil survey of Washington and Wilkinson Counties, Georgia. 941

[Washington, D.C.] : The service, [1985].

SOILS--INDIA--CLASS IFICATION.

Benchmark soils of India : morphology, characteristics, and classification for resource management. Nagpur [India] : The Bureau, cl982. 941 (640 B432 


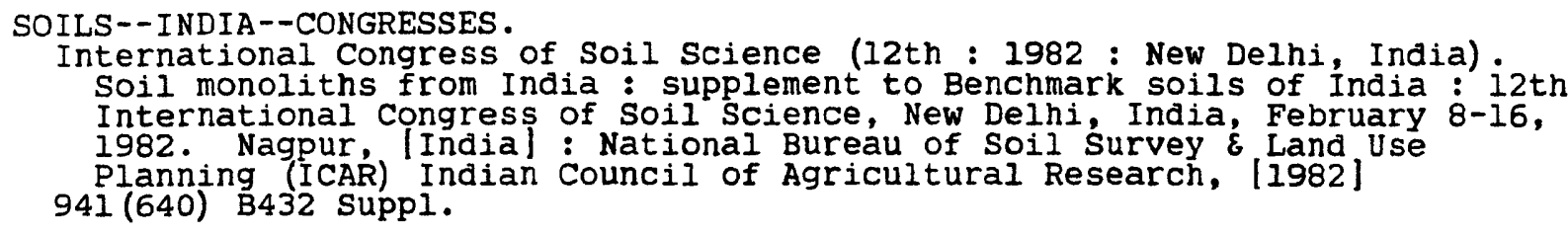

SOILS--IOWA-DUBUQUE COUNTY

Boeckman, Louis E. Soil survey of Dubuque County, Iowa. [Washington, D. 941

C.]: The Service, [1985]

SOILS--KOREA.

Kawamura, Kazumi. On the terra-rossa-like soils in western Korea (Chösen).

Tokyo, Japan: Pacific Geological Surveys, Military Geology Branch, U.S.G.S., 1950

209 (900) qun33pr no. [439]

SOILS--MISSISSIPPI--MARION COUNTY.

Nichols, Paul. Soil survey of Marion County, Mississippi. [Washington, 941 D.C.I': The Service, [1985]

SOILS--NEBRASKA--CEDAR COUNTY .

Milliron, E. Larry. Soil survey of Cedar County, Nebraska. [Washington, 941

D.C.I : The Service, 1985.

SOILS--NEBRASKA--VALLEY COUNTY--MAPS.

Soil survey of Valley County, Nebraska. [Washington, D.C.] : The Service, 941 1985

SOILS--NETHERLANDS

Steur, G. G. L. Algemene begrippen en indelingen, Bodemkaart van Nederland schaal 1:50 000. Wageningen : Stichting voor Bodemkartering, 1980.

$941(591)$ W12sb3a

SOILS--NITROGEN CONTENT.

Lembi, Carole A. Evaluation of nitrogen application technique and tillage system on nitrogen runoff from an erodible soil. West Lafayette, IN : Water Resources Research Center, Purdue University, [1985]

S (252) qP972t no.174

SOILS--SOUTH CAROLINA--OCONEE COUNTY.

Herren, Edward C. Soil survey of Sumter National Forest Area, Oconee 941 County, South Carolina. [Washington, D.C.] : The Service, [1985]

SOILS--SOUTH DAKOTA--BRULE COUNTY-MAPS .

Vialle, Regis L. Soil survey of Brule and Buffalo Counties, South Dakota. 941

[Washington, D.C.] : The Service, [1985]

SOILS--SOUTH DAKOTA--POTTER COUNTY.

Faulkner, Allen A. Soil survey of Potter County, South Dakota. 941

[Washington, D.C.] : The Service, [1985] 


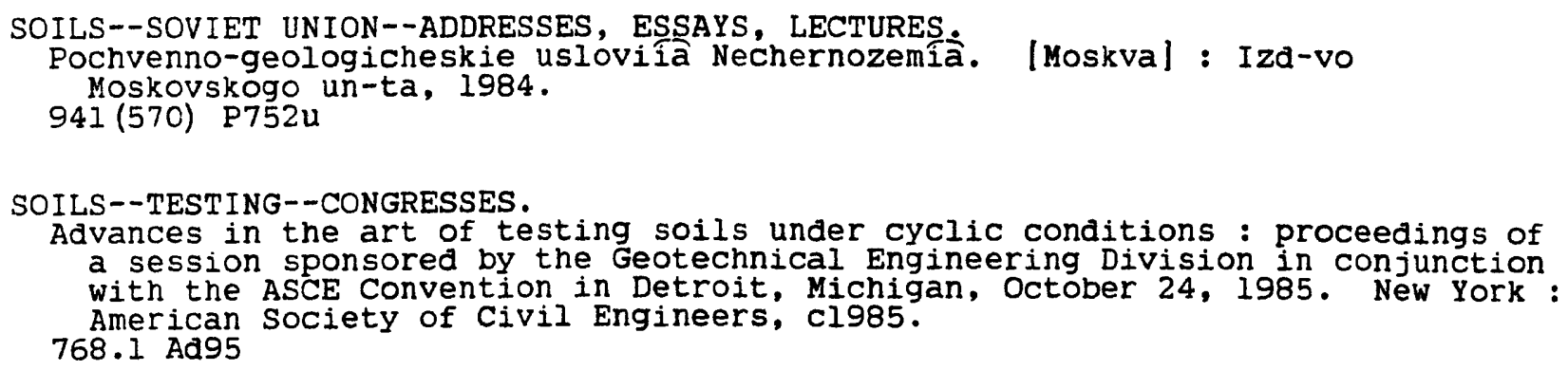

SOILS--TEXAS--WEBB COUNTY.

Sanders, Russell $R$. Soil survey of Webb County, Texas. [Washington, D.C.] : 941 The Service, 1985.

SOILS--THE WEST--ANALYSIS.

Severson, R. C. Results of the Second Western Task Force Round Robin Soil and Overburden Analysis Program. [Denver, Co] : U.S. Geological survey, 1986.

(200) R29o no.86-49 D MP

SOLAR RADIATION--GREENLAND SEA REGION.

Radiatsionnyi rezhim Grenlandskogo i Norvezhskogo morei. Leningrad : Gidrometeoizdat, 1983.

$530(055)$ RII8

SOUTH AFRICA--MINERAL RESOURCES--MAPS.

Geological Survey of South Africa. Mineral deposits and occurrences in South Africa = Delstofafsettings en voorkomste in Suid-Afrika.lst ed. [Pretoria, Republic of South Africa] : The Survey, 1977-1982. $M(787) 41982 \mathrm{~g}$

SOUTHERN STATES--GEOLOGY--GUIDEBOOKS.

Field trip guides for Geological Society of America annual meeting, Southeastern and North-Central Sections, Lexington, Kentucky, April 4-5 1984. Lexington, Ky. : Dept. Of Geology, University of Kentucky, [1984]

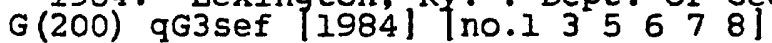

SOVIET UNION--GEOLOGY .

Praktikum po geologii SSSR (Russkaîa platforma) : dopushcheno Ministerstvom vysshego i srednego spetsialhogo obrazovaniia SSSR v kachestve uchebnogo posobiia dila studentov geologicheskikh spetsialhostei vysshikh uchebnykh zavedenil. Moskva : Vysshaîa shkola, 1966. $305(570)$ P884 D MP

Smirnova, Muza Nikolaevna. Osnovy geologii SSSR. Izd. 3., perer. i dop. Moskva : Vysshaia shkola, 1984. $203(570) \operatorname{sm} 4801984$

SOVIET UNION--GEOLOGY--HISTORY--ADDRESSES, ESSAYS, LECTURES.

StraniEsy istorii moskovskoi geologicheskoi shkoly. Moskva : Nauka, 1985.

$207(570)$ Och 3 vyp. 22 
STRAINS AND STRESSES--MEASUREMENT.

Dart, R. L. Horizontal-stress directions in the Denver and Illinois Basins from the orientations of borehole breakouts. [Denver, Colo.] : U.S. Geological Survey, 1985.

(200) R290 no.85-733 D MP

STREAM-GAGING STATIONS--LOUISIANA.

Herbert, Richard A. Cost effectiveness of the stream-gaging program in Louisiana. Baton Rouge, Louisiana : U.S. Geological Survey, 1985. (200) WRi no.85-4044 D MP

STREAM MEASUREMENTS.

Practical hydrometry of watercourses = Hydrométrie pratique des cours d'eau. [Cairo, Egypt] : Al-Anram Center for Scientific Translations, 1981. 783 H995pE

STREAM MEASUREMENTS--APPALACHIAN REGION.

Wetzel, Kim L. Techniques for estimating streamflow characteristics in the Eastern and Interior Coal provinces of the United States. [Washington, $D$. C.] : GPO, 1986.

(200) G no.2276 D MP

STREAM MEASUREMENTS--TEXAS.

Massey, B. C. Texas stream-gaging program : an analysis of data uses and funding. Austin, Tex. : U.S. Geological Survey, 1985.

(200) R290 no.85-084

STREAM MEASUREMENTS--WYOMING.

Schuetz, Joel R. Use and availability of continuous streamflow records in Wyoming. Cheyenne, Wyo. : U.S. Geological Survey, 1986.

(200) R290 no.85-685

STREAM MEASUREMENTS--WYOMING--HORSE CREEK.

Meyer, J. F. Discharge and water quality of Horse Creek, southeastern Wyoming, May - November, 1985. Cheyenne, Wyo.: U.S. Geological Survey, 1986.

(200) R290 no.86-69

STRIP MINING.

Ilín, A. I. Upravlenie dolgovremennoi ustoíchivostiu otkosov na karérakn. Moskva : Nedra, 1985.

425 II $15 \mathrm{u}$

STRIP MINING--NORTH DAKOTA.

Progress report on research on reclamation of strip-mined land in the Northern Great Plains. Mandan, N.D. : Northern Great Plains Research Center, 1975.

$P(200)$ Ai2gpr

STROMATOLITES.

Grey, Kathleen. Biostratigraphic studies of stromatolites from the Proterozoic Earaheedy Group, Nabberu Basin, Western Australia. Perth : G. P.O. , 1984 .

(860) D no.130

STROMATOLITES--INDIA--JAMMU AND KASHMIR.

Raha, P. K. Stratigraphy of the Jammu Limestone (Great Limestone), Udhampur District, Jammu and Kashmir state, with special reference to its stromatolite content and age. Calcutta : Director General, Geological Survey of India, 1984.

(640) qP no.47 
STROMATOPOROIDEA

Bolśnakova, L. N. Stromatoporaty i biostratigrafiîa nizhnego paleozoîa Mongolii. Moskva : Nauka, 1985.

$680(619)$ So92t vyp.27

SUBJECT HEADINGS--GEOLOGY.

GeoRef thesaurus and guide to indexing. 4th ed. Alexandria, va. :

American Geological Institute, c1986.

RO 045.6 G296t 1986 D MP F

SUBMARINE GEOLOGY.
Shepard, Francis parker. Submarine geology. 3d ed. New York : Harper
\& Row, I973.
$203(050)$ Sh4s 1973

SUBMARINE GEOLOGY--CARIBBEAN SEA--MAPS.

Géologie de la ride d'Aves et des pentes sous-marines du nord des petites Antilles et esquisse bathymétrique a $1 / 1.000 .000$ de l'Est-Caraibe. orléąs, France : Editiones du Bureau de recherches géologique et Minieres, Service géologiques national, 1985.

(540) qR2d no 93

SUBMARINE GEOLOGY--NORTH PACIFIC OCEAN.

Tectonics of the northwestern part of the Pacific ocean = Tektonika severozapadnoi chasti Tikhogo okeana. [Reston, Va.] : The survey, [1985] $203(081)$ T235sE

SUN--PROMINENCES.

Morozhenko, N. N. Spektrofotometricheskie issledovani住 spokoinykh solnechnykh protuberantsev. Kiev : Nauk. dumka, 1984. 730.1 M832s

SWEDEN--GEOLOGY --STRÄNGNÄS-MAPS .

Stàlhös, Göran. Berkrivning till berggrundskarțan Strängnäs so $=$ Description to the map of solid rocks strangnas so. Uppsala : Sveriges geologiska undersokning, 1982.

(583) Af $\mathrm{Nr} .142$

TANTALITE--SOUTH AFRICA.

Levin, Jack. The recovery of tantalite and cassiterite from a bulk sample of pegmatite supplied by Falconbridge Explorations Limited. Randburg, S.A. : Council for Mineral Technology, 1984.

$S(787)$ qN2I3r no.M42D

TECHNOLOGY--DICTIONARIES--GERMAN .

Dictionary of technology : German, English. Amsterdam ; New York : Elsevier, 1985, c1967.

R 051.1 G3WI72d

TECHNOLOGY--DICTIONARIES--RUSSIAN .

Russko-angliłskii politekhnicheskii slovar': okolo 90,000 terminov. Izd. 2, stereotip. Moskva : Izd-vo Russkili iazyk, 1980.

R 05I.I R9k96r 1982

TEETH, FOSSIL.

Fortelius, Mikael. Ungulate cheek teeth : developmental, functional, and evolutionary interrelations. Helsinki : Finnish Zoological Publishing

Board, 1985.

$S(579)$ F36az no. 180 
TEMPERATURE--COLLECTED WORKS.

Temperature, its measurement and control in science and industry. New York : The Institute, 1941-1982. $830 \operatorname{Am} 33 t$

TERRAIN STUDY (MILITARY SCIENCE) .

Frodigh, Roland J. Terrain analysis procedural guide for built-up areas. Fort Belvoir, Va. : U.S. Army Corps of Engineers, Engineer Topographic Laboratories, [1984]

P (200) W12letI no.0354

Mintzer, Olin W. Terrain analysis procedural guide for surface configuration. Fort Belvoir, Va.: U.S. Army Corps of Engineers, Engineer Topographic Laboratories, [1984]

$P(200)$ W12let 1 no.0352

Tazelaar, James $F$. Terrain analysis procedural guide for geology. Fort Belvoir, Va. : U.S. Army Corps of Engineers, Engineer Topographic Laboratories, 1979 .

$P(200)$ Wl2letI no.0207

Terrain analysis procedural guide for soil. Fort Belvoir, Va. : U.S. Army Corps of Engineers, Engineer Topographic Laboratories, [198i]

$P(200)$ W12let I no.0254

TERRESTRIAL HEAT-FLOW--GREAT BRITAIN.

Wheildon, $J$. Future investigations of the UK heat flow field (1981-1984). Keyworth [England] : British Geological survey, 1985.

(510) qW572f 1985

TERRESTRIAL MAGNETISM--ALASKA--FAIRBANKS .

Preliminary geomagnetic data, College observatory, Fairbanks, Alaska :

December 1985. [Denver, Có]. : U.S. Geological Survey, [1985]

(200) R290 no.85-300L

TERRESTRIAL MAGNETISM--GERMANY--BOHEMIAN FOREST.

Berktold, Alfred. Tiefensondierung mit Hilfe ger variationen des erdmagnetischen und erdelektrischen Feldes langs eines Profils vom oberpfalzer Wald durch das nordliche Alpenvorland bis zu den Kitzbüheler Alpen. [1969]

$296(530)$ B455t

TERRESTRIAL MAGNETISM--GERMANY, WEST--RHINELAND-PALATINATE.

Dachroth, Wolfgang Rüdiger. Zur stratigraphischen Korrelation auf Grund des gesteinsmagnetischen Verhaltens und Anwendung auf das oberrotliegende und den Bundsandstein von Rheinland-Pfalz und Saar. 1969.

$296(530)$ Dl16z

TERRESTRIAL MAGNETISM--MAINE--MAPS.

Bothner, W. A. Preliminary aeromagnetic map of the Lewiston and Sherbrooke quadrangles, Maine - New Hampsire - Vermont. [Denver, Colo.] : U.S. Geological Survey, [1985]

$M(211) 296$ L588b -- (200) R290 no.85-501 -- (200) R290 no.85-501

TEXAS--GEOLOGY--CHARTS, DIAGRAMS, ETC.

Morton, Robert A. Structural cross sections, Miocene series, Texas continental shelf. Austin, Texas : Bureau of Economic Geology, the University of Texas at Austin, 1985.

(200) qM846s $1985 \mathrm{D}$ 
TEXAS--GEOLOGY--GUIDEBOOKS.

Landscape and land use in central Texas : 29th annual Clay Minerals Conference. [Waco, Tex.] : Baylor University, 1980.

$209.1(245)$ L238

TEXTURE (CRYSTALLOGRAPHY) .

Garcia Celma, Maria Desamparados. C-axis- and shape-fabrics in quartzmylonites of Cap de Creus (Spain) : their properties and development. [S. 1.: s.n., 1983?]

$113(560)$ qGísc

THERMAL ANALYSIS--CONGRESSES.

Thermoanalytical methods in science and practice : proceedings of the tenth German Thermal Analysis Society (GEFTA) Conference, Paderborn, F.R.G., 19-21 March 1984. Amsterdam; Oxford : Elsevier, [1985]

852 T414 v.83 no.1

THERMAL OIL RECOVERY.

Baibakov, Nikolai Konstantinovich. Thermal methods of oil field development $=$ Teplovye metody razrabotki neftianykh mestorozhdeni [Reston, Va. ] : The survey, 1983.

467.4 B148tE 1981

THIAN SHAN MOUNTAINS--PHYSICAL GEOGRAPHY--BIBLIOGRAPHY.

Zherdeva, V. A. Tîan'shanśkaià fiziko-geograficheskàîa stantSîa : annotirovannyi bibliograficheskii ukazatel'rabot 19641980 gg. Frunze : Ilim, 1985.

$042.503(695.6) \mathrm{z} 61 \mathrm{t}$

TIDAL CURRENTS--CALIFORNIA--SAN FRANCISCO BAY.

Gartner, Jeffrey $W$. Tidal and residual currents in south San Francisco Bay, California : results of measurements, 1981-83. [Menlo Park, CA] : U.S. Geological Survey, [1986]

(200) WRi no.86-4024 D MP

TIDAL CURRENTS--CALIFORNIA--SAN FRANCISCO BAY REGION.

Gartner, Jeffrey $W$. Tidal and residual currents near the confluence of the Sacramento and San Joaquin Rivers, California: results of measurements, 1984-85. [Menlo Park, CA] : U.S. Geological survey, [1986]

(200) WRi no.86-4025 D MP

TIN ORES--SOUTH AFRICA.

Strydom, J. H. Geochemie en mineralogie van Tindraende pype in die

Zaaiplaatsmyn, Distrik Potgietersrus. Pretoria : Govt. Printer, 1984.

(787) B no.76

TOXICOLOGY.

Chemical hazard information profiles (CHIPS); August 1, 1976, to November 20, 1979. Washington, D.C. : The Office, [1980]

$P(200)$ En85ptc

TRACE ELEMENTS.

Horowitz, Arthur J. A primer on trace metal-sediment chemistry. [Washington, D.C.] : U.S. G.P.O., 1985.

(200) G no.2277 D MP 
TRACE ELEMENTS--CALIFORNIA--KERN COUNTY--MAPS.

Miller, W. R. Maps showing distribution of anomalous concentrations of trace elements in the nonmagnetic fraction of heavy-mineral concentrates and of uranium in the less-than-0.180-millimeter fraction of selected stream sediments, Domeland Wilderness and contiguous roadless areas, Kern and Tulare Counties, California. Reston, Va.: U.S. Geological Survey, 1985. M (276) 413 D712m -- M(200) 4 vUn3mf no.1395-C -- M(200) MF no.1395-C

Miller, W. R. Maps showing distribution of anomalous concentrations of trace elements in the magnetic fraction of heavy-mineral concentrates. Domeland Wilderness and contiguous roadless areas, Kern and Tulare Counties, California. Reston, Va.: U.S. Geological Survey, 1985.

M (276) 413 D712md -- M(200) 4 vUn3mf no.1395-D -- M(200) MF no.1395-D

TRAVERTINE--THE WEST--MAPS.

Feth, John Henry Frederick. Map showing occurrences of spring-deposited travertine in the conterminous Western United States. Menlo Park, CA:U. S. Geological survey, 1979.

M (200) 471 W525f

TRILOBITES.

Chatterton. B. D. E. Silicified Silurian odontopleurid trilobites from the Mackenzie Mountains. Calgary, Alberta : Canadian Society of Petroleum Geologists ; Toronto, Ontario: Geological Association of Canada, 1983. 602 (100) Pl72 no.1

TSUNAMIS--CONGRESSES .

GeneraEsi îa Esunami i vykhod voln na bereg : posvîashchaetsîa 100letiiu mezhdunarodnykh geofizicheskikh issledovanii. Moskva : Radio i sviaz', 1984 .

$533(050)$ G286t

TSUNAMIS-PACIFIC OCEAN--MAPS.

National Geophysical Data Center. Tsunamis in the Pacific Basin, 1900-1983. Boulder, Colo. : National Geophysical Data Center, 1984.

$M(080) 2491984 \mathrm{n}$ D MP

TURKEY--GEOLOGY--MUĞLA PROVINCE.

Bassaget, Jean-Pierre. Contribution à l'étude géologique de la région au Sud du massif du Menderes entre Fethiye et Sandras Dag, Province de Muğla, Turquie. 1966.

$203(598)$ B293C

UKRAINE--GEOLOGY--BIO-BIBLIOGRAPHY.

Kharitonov, O. M. Vsevolod Borisovich Sollogub. Kiev : Nauk. dumka, 1982 .

087 So $46 \mathrm{k}$

UNITED NATIONS ENVIRONMENT PROGRAMME. REGIONAL SEAS PROGRAMME.

Regional Seas Programme in Latin America and wider Caribbean. Geneva, Switzerland : Programme Activity Centre for Oceans and Coastal Areas, United Nations Environment Programme, 1984. 537.5 qun22 no.22 Rev.2

UNITED STATES--ECONOMIC CONDITIONS--1981.

The Economic and budget outlook : an update, washington, D.C. : The office : For sale by the Supt. of Docs., U.S. G.P.O., [1983]

$P(200) \quad C 724 \mathrm{ceb}$ 
UNITED STATES.--GEOLOGY--HISTORY--COLLECTED WORKS.

Centennial special volume (Geological Society of America) Centennial special volume / Geological Society of America]. Boulder, Colo.: The Society, 1985-

R G(200) qG28C

URANIUM ORES.

Promyshlennye tipy uranovykh mestorozhdeni i i metodika ikh poiskov.

Leningrad : Nedra, Leningradskoe otd-nie, 1984. 439 P944t

URANIUM ORES--AUSTRALIA--NORTHERN TERRITORY.

Nutt, Connie J. Description of drill-hole GNO42V core from the Jabiluka unconformity-type uranium deposit, Northern Territory, Australia. IDenver, CO) : U.S. Geological Survey, 1986.

(200) R290 no.85-134 D MP

URANIUM-TREND DATING.

Uranium-trend dating of Quaternary deposits in the Nevada Test Site area, Nevada and California. Lakewood, Colo. : U.S. Geological Survey, 1985.

(200) R290 no.85-540 D MP

URBAN HYDROLOGY --CONGRESSES.

International symposium on Urban Hydrology, Hydraulic Infrastructures, and Water quality control (1985 : Lexington, KY.). Proceedings. Lexington, Ky : OES Publications, College of Engineering, University of Kentucky, [1985]

780.01 In8pu

URBAN RUNOFF--DATA PROCESSING--CONGRESSES .

Engineering Foundation Conference on Emerging Computer Techniques (1983 : Niagara-on-the-Lake, ont., Canada). Emerging computer techniques in

stormwater and flood management : proceedings of the conference. New york, N.Y. : American Society of Civil Engineers, Cl984.

799 En $34 \mathrm{e}$

USGSPUB.

Hydrologic data in small watersheds, coal-mining region, west-central Indiana, October 1980 to June 1983, and instrumentation and methods of collecting the data. Indianapolis, Ind. : U.S. Geological Survey, 1985.

(200) R290 no.85-402

UTAH--GEOLOGY--NIPPLE BUTTE QUADRANGLE--MAPS.

waldrop, Henry A. Preliminary geologic map and coal deposits of the northeast quarter of the Nipple Butte quadrangle, Kane County, Utah. salt Lake City, Utah : Published and sold by the Utah Geological and Mineralogical survey, [1967?]

$M(273) 461$ N627w2

UTAH--MINERAL RESOURCES--GARFIELD COUNTY--MAPS.

Mineral resource potential map of the Mt. Elien-Blue Hills Wilderness Study Area and Bull Mountain Study Area, Garfield and Wayne Counties, Utan. Reston, Va. : U.S. Geological Survey, 1985.

M(273) 4 M864d -- M(200) 4 vUn3mf no.1756-A -- M(200) MF no.1756-A

UTAH--PHOTO MAPS.

Geological Survey (U.S.). Great Salt Lake and vicinity, Utah : Satellite image map. Experimental edition. Reston, Va. : U.S. Geological Survey, 1984 .

$M(273) 5.119849$ 
VENEZUELA--GEOLOGY--CONGRESSES.

Congreso Geológico Venezolano (6th : 1985 : Caracas). Memoria. Caracas : Sociedad Venezolana de Geólogos, 1985-

$201(470)$ C762m 1985

VERTEBRATES, FOSSIL--CATALOGS AND COLLECTIONS.

Neas, John F. Type and figured specimens of fossil vertebrates in the collection of the University of Kansas Museum of Natural History : Part III. Fossil birds. Lawrence, Kan. : the University of Kansas, 1986. $570(267)$ T981 pt.3

VICTORIA, AUSTRALIA--GEOLOGY--BACCHUS MARSH REGION--MAPS.

Roberts, P. S. Explanatory notes on Bacchus Marsh and Ballan 1:50 000 geological maps; [Melbourne, Victoria, Australia] : Geological survey of Victoria, [1984]

(830) qG292 no.76

VICTORIA, AUSTRALIA--GEOLOGY--BALLARAT REGION--MAPS.

King, R. L. Explanatory notes on the Ballarat 1:250 000 geological map. [Melbourne, Victoria, Australia] : Geological Survey of Victoria, 1985. (830) qG292 no.75

VICTORIA, AUSTRALIA--GEOLOGY--TALLANGATTA REGION--MAPS.

Bolger, P. F. Explanatory notes on the Tallangatta i : 250000 geological map. [Melbourne, Victoria, Australia] : Geological Survey of Victoria, [1984]

(830) qG292 no.73

VIRGINIA--GEOLOGY --ALLEGHANY COUNTY--MAPS.

Lesure, Frank Gardner. Geologic map of the Rich Hole Roadless Area, Alleghany and Rockbridge Counties, Virginia. Reston, Va. : U.S. Geological Survey, 1985.

M(227) 2 R3721 - M (200) 4 vUn 3mf no.1760-A -- M(200) MF no.1760-A

VIVERRIDAE.

Gingerich, Philip D. Systematics of Paleocene Viverravidae (Mammalia, Carnivora) in the Bighorn Basin and Clark's Fork Basin, Wyoming. Ann Arbor: Museum of Paleontology, The University of Michigan, [1985] $G(255)$ M $58 \mathrm{C} v .27$ no.4

VOLCANIC ACTIVITY MONITORING--SICILY.

Bonneville, Alain. Analyses des températures de surface de deux volcans actifs : Etna et Piton de la Fournaise. Montpellier, France : Centre géologique et géophysique, Université de sciences et techniques du Languedoc, [1985]

$G(540)$ qC334d 1985 no 7

VOLCANISM .

Kotliar, v. N. Vulkanizm i orudenenie. Moskva : Nedra, 1984.

$410 \mathrm{~K} 848 \mathrm{v}$

VOLCANISM--PACIFIC OCEAN.

Moiseenko, V. G. Glubinnye flîuidy, vulkanizm i rudoobrazovanie Tiknookeanskogo poîasa. Moskva : Nauka, 1982.

$170(080) \quad$ M728g 
VOLCANISM--SOVIET UNION.

Sarkisian, S. Sh. Geologicheskie osnovy vulkanogennogo rudoobrazovaniìa. Moskva : Nedra, 1984.

$410(570) \mathrm{Sa} 3 \mathrm{~g}$

VOLCANITE--GERMANY, WEST--LAHN RIVER WATERSHED.

Strauss, Karl W. Geologie und Petrologie der Vulkanite des Hohensolmser Deckdiabas-Gebietes. 1983.

$170(530)$ St82g MP

VOLCANOES--JAPAN--OKINAWA ISLANDS.

Musya, Kinkiti. Principal earthquakes and volcanic eruptions in the Okinawa Islands. [Tokyo, Japan] : U.S. Geological Survey, Pacific Geological Surveys, 1949 .

$209(900)$ qun $33 \mathrm{pr}$ [no.483]

WASTE DISPOSAL IN THE GROUND--IRELAND.

Daly, D. Waste disposal sites : geotechnical guidelines for their seiection, design and management. [S.I]: Geological survey office, 1982. (515) qIC no.82-1

WATER--COMPOSITION--FLORIDA--ST. PETERSBURG REGION--MAPS.

Corral, M. A. Distribution of selected chemical constituents in water from the Floridan aquifer, Southwest Florida Water Management District. [Tallahassee, Fla.] : U.S. Geological Survey, 1983.

M (234) 495 So89C 1983

WATER CONSUMPTION--WEST VIRGINIA--OBSERVATIONS.

Suder, Kimberly E. Water use in West Virginia for 1983. Morgantown, WV : West Virginia Geological and Economic Survey, 1985.

(228) qW3C no.37

WATER--ECONOMIC ASPECTS--CONGRESSES.

New Mexico Water Conference (1Ith : 1966 : New Mexico State University). Water economics with limited supplies and an increasing population : Eleventh Annual New Mexico Water Conference, March 31 and April 1, 1966. University Park : Milton Student Center, New Mexico State University, [ig66] $780(272)$ qN465n no.11

WATER--POLLUTION--LAW AND LEGISLATION--UNITED STATES.

United States. Congress. House. Committee of Conference. Federal water pollution control act amendments of 1972 : conference report. Washington: U.S. G.P.O., 1972 . 795 Un28fa

WATER QUALITY--CALIFORNIA--KERN COUNTY--MAPS.

Miller, W. R. Maps showing distribution of anomalous concentrations of elements in water, Domeland Wilderness and contiguous roadless areas, Kern and Tulare Counties, California. Reston, Va. : U.S. Geological Survey, 1985.

M (276) 495 D712m - M (200) 4 vUn3mf no.1395-E -- M(200) MF no.1395-E

WATER QUALITY--COLORADO--MEASUREMENT.

Water-quality data-collection activities in Colorado and Onio : phase 1, inventory and evaluation of 1984 programs and costs. Lakewood, Colo.' U. S. Geological survey, 1985.

(200) R290 no.85-574 
WATER QUALITY--CONGRESSES.

Symposium on Groundwater, Geochemical and Environmental Relationships (1985: Troy, N.Y.). Proceedings of the Symposium on Groundwater, Geochemical and Environmental Relationships: May 30-31, 1985. Troy, N.Y. : Northeastern Science Foundation, Inc., cl985.

$\mathrm{S}(221) \mathrm{N} 815 \mathrm{v} .4 \mathrm{no.2}$

WATER QUALITY--IOWA.

Detroy, Mark G. Iowa ground-water-quality monitoring program. IReston,

va.]': U.S. Geological Survey, [1985]

(200) R290 no.84-815 D MP

WATER QUALITY--KARELIAN ISTHMUS (R.S.F.S.R.) •

Osobennosți formirovani ia kachestva vody $v$ raznotipnykh ozerakh karelskogo

peresheika. Leningrad : Nauka, Leningradskoe otd-nie, 1984.

$797(570)$ Os5

WATER QUALITY--MAINE--CUMBERLAND COUNTY--MAPS.

Lewis, David $E$. Iron and nitrates in bedrock well water - Cumberland

County, Maine. Augusta : Maine Geological Survey, 1979.

M(211) 495 C9121

WATER QUALITY MANAGEMENT--NEW MEXICO--CONGRESSES.

New Mexico Water Conference (28th : 1983 : New Mexico State University) . Water quality in New Mexico : proceedings of the twenty-eighth annual New Mexico Water Conference, April 5-6, 1983. Las Cruces, N.M. : New Mexico Water Resources Research Institute, 1983. $780(272)$ qN465n no.28

WATER QUALITY--MIDDLE WEST--MAPS.

Omernik, James M. Total alkalinity of surface waters : a map of the Upper Midwest region. Corvallis, or. : Environmental Research Laboratory, U.S. Environmental Protection Agency, [1985]

$P(200)$ En850tu

WATER QUALITY--MINNESOTA--MAPS .

Ruhl, J.F. Hydrogeologic and water-quality characteristics of the IrontonGalesvilie aquifer, southeast Minnesota. St. Paul, Minn. : U.S. Geological survey, 1982.

M (261) 797 So88r

WATER QUALITY--NEW ENGLAND--MAPS.

Omernik, James M. Total alkalinity of surface waters : a map of the New England and New York region. Corvallis, or. : Environmental Research Laboratory, U.S. Environmental Protection Agency, [1985]

$P(200)$ qEn85otn

WATER RESOURCES DEVELOPMENT.

Water as a factor in energy resources development. New York : United

Nations, 1985.

$552(600)$ qun2bef no. 60

WATER RESOURCES DEVELOPMENT--ALASKA--ANCHORAGE--MAPS.

Brunett, Jilann. Hydrogeology for land-use planning: the Peters Creek area, Municipality of Anchorage, Alaska. [Reston, Va.] : U.S. Geological survey, 1983.

M (286) 784 An22b 
WATER RESOURCES DEVELOPMENT--CALIFORNIA.

Joint environmental impact statement and environmental impact report :

proposed agreement between the United States of America and the Department of Water Resources of the State of California, for coordinated operation of the Central Valley Project and the State water Project ; [draft].

Sacramento, CA: [s.n., 1985] $585.3(276)$ Un $36 j d$

WATER RESOURCES DEVELOPMENT--CANADA.

Pearse, Peter H Currents of change : final report. [Ottawa, Canada]: The Inquiry, [1985] $780(100)$ P 317 C D

WATER RESOURCES DEVELOPMENT--ECUADOR--JUBONES RIVER WATERSHED.

Plan hidráulico del Jubones. [S.I.] : Secretaría General de la Organización de los Estados Americanos, [1985?]

784 (465) qP692j MP

WATER RESOURCES DEVELOPMENT--ENVIRONMENTAL ASPECTS--COLORADO--ALAMOSA COUNTY .

San Luis Valley Project, Colorado, Closed Basin Division, Alamosa and Saguache Counties : araft supplement to final environmental statement. Amarilio, Tex.: The Bureau, 1982. $585.3(271)$ Un36sf

WATER RESOURCES DEVELOPMENT--FLORIDA--TAMPA--MAPS.

Stewart, J. W. Hydrogeology of the Sulphur Springs area, Tampa, Florida. [Tallanassee] : U.S. Geological Survey, 1984. M (234) 784 Su52s

WATER RESOURCES DEVELOPMENT--GUAM .

Potential water resources development Guam : special report and environmental assessment. Agana, Guam : The Office, [1985] $784(970)$ P848sr 1985

WATER RESOURCES DEVELOPMENT--KANSAS--CONGRESSES.

Huntzinger, Thomas L. Federal-State Cooperative Program in Kansas: seminar proceedings, JuIy 1985. Lawrence, Kansas : U.S. Geological Survey, 1985. (200) R29́o no.85-641 D MP

WATER RESOURCES DEVELOPMENT--NEW MEXICO--CONGRESSES.

New Mexico Water Conference (17th : 1972 : New Mexico State University). Water in land use planning : proceedings of the Seventeenth Annual New Mexico Water Conference, New Mexico State University, Las Cruces, New Mexico [April 6-7, 1972]. Las Cruces : New Mexico State University, 1972. $780(272)$ qN465n no.i7

WATER RESOURCES DEVELOPMENT--SOUTH DAKOTA--DEUEL COUNTY. Kume, Jack. Water resources of Deuel and Hamlin Counties, South Dakota. Huron, S.D. : U.S. Geological Survey, 1985. (200) WRi no.84-4069 D MP

WATER RESOURCES DEVELOPMENT--UNITED STATES.

Water resource project selection at the iocal, state, and federal levels : final report. Cambridge, Mass. : The Agency ; Springfield, Va. : NTIS, $[1973]$.

$784(200)$ W292 
Water Resources Council (U.S.). Policies, standards, and procedures in the formulation, evaluation, and review of plans for use and development of water and related land resources. Washington : U.S. G.P.O., 1962.

$P(200)$ W29lp 1962

WATER RESOURCES DEVELOPMENT--UNITED STATES--FINANCE.

United States. Congress. Senate. Committee on Appropriations. Subcommittee on Energy and Water Development. Energy and water development appropriations for fiscal year 1984 : hearings before a subcommittee of the Committee on Appropriations, United States Senate, Ninety-eighth Congress, first session, on H.R. 3132. Washington : U.S. G.P.O., 1983.

$P(200)$ C727el9e 1984

WATER RESOURCES DEVELOPMENT--VIRGIN ISLANDS OF THE UNITED STATES.

A jayi, Owolabi. Compendium of water resources data for the U.S. Virgin Islands. St. Thomas, V.I. : Caribbean Research Institute, College of the Virgin Islands, [1983]

$\mathrm{S}(394 . \mathrm{I}) \mathrm{T} 226 \mathrm{no.12}$

WATER-STORAGE--TEXAS .

Vaugh, Samuel K. Storage projection for reservoir systems : a case study of the Highland Lakes. Austin, Tex. : Center for Research in water Resources, University of Texas at Austin, [1985]

s (245) Un3trc no.216

WATER-SUPPLY, RURAL--HANDBOOKS, MANUALS, ETC

Rural water supply design manual. Qluezonj Clity] : The Council, [1980]

$793(920)$ R882d

WATER, UNDERGROUND--CALIFORNIA--SANTA ANA RIVER VALLEY--MAPS.

Carson, Scott E. Contour map showing minimum depth to ground water, Upper Santa Ana River Valley, California, 1973-1979. Reston, Va. : U.S.

Geological Survey, 1985.

M (276) 49 Sa58C -- M(200) 4 vUn $3 m f$ no.1802 - M (200) MF no.1802

WATER, UNDERGROUND--EL SALVADOR--ADDRESSES, ESSAYS, LECTURES .

Sayre, Albert Nelson. [Abastecimiento de agua municipal en El Salvador] : reports on municipal water supplies in the Republic of El salvador, Central America (Spanish versions). [S.1. : s.n., 1944?]

$791(384)$ qSa98a

Sayre, Albert Nelson. Reports on municipal water supplies in the Republic of El Salvador, Central America. [S.1. : s.n., 1948?]

$791(384)$ qSa98r

WATER, UNDERGROUND--FLORIDA--MAPS .

Geological Survey (U.S.). Potentiometric surface of the Floridian aquifer in the St. Johns River Water Management District and vicinity, Florida, May 1983. [Tallahassee, Fla.] : U.S. Geological Survey, 1983.

M (234) 49 Sa23 May 1983 - (200) R29o no.83-687 -- (200) R29o no.83-687

Phelps, G. G. Recharge and discharge areas of the Floridan aquifer in the St. Johns River water Management District and vicinity, Florida. [Tallanassee, Fla.] : U.S. Geological Survey, 1984.

M (234) 49 1984p 
Rodis, Harry G. Potentiometric surface of the Floridan aquifer and its use in management of water resources, St. Johns River Water Management District, Florida. [Tallahassee, Fla.]: U.S. Geological Survey, 1983. M (234) 49 N815r

WATER, UNDERGROUND--FLORIDA--ST. PETERSBURG REGION--MAPS.

Yobbi, D. K. Trends and fluctuations in the potentiometric surface of the Floridan aquifer, West-central Florida 1961-1980. [Tallanassee, Fla.]: U. S. Geological Survey, 1983.

M (234) 49 W552y 1983

WATER, UNDERGROUND--IRELAND--MAINE RIVER WATERSHED.

Scanlon, Bridget $R$. A groundwater study of the Maine River Basin, County Kerry: [S.I.] : Geological Survey of Ireland, 1985.

(515) Rig8s no.85-1

WATER, UNDERGROUND--KANSAS.

Kume, Jack. Geohydrology of sandstone aquifers in southwestern Kansas. Lawrence, Kan. : Kansas Geological Survey, 1985.

(267) $\mathrm{K} 4 i$ no. 8

WATER, UNDERGROUND--KANSAS--MATHEMATICAL MODELS.

Cobb, Patrick M. An automated numerical evaluation of leaky aquifer pumping test data : an application of sensitivity analysis. Lawrence, Kansas : Kansas Geological Survey, 1982. (267) K4gws no.6

WATER, UNDERGROUND--LOUISIANA.

Lurry, Dee L. Public water supplies in Louisiana : v. 1: northern Louisiana. Baton Rouge, Louisiana Dept. of Transportation and Development, 1985.

$780(237)$ L93br no.13

WATER, UNDERGROUND--MAINE--AROOSTOCK COUNTY--MAPS.

Tolman, Andrews L. Sand and gravel aquifers map 74: Aroostook and

Penobscot Counties, Maine. [Augusta] : Maine Geological Survey, 1980.

M (211) 49 Sa56t no. 74

WATER, UNDERGROUND--MAINE--AROOSTOOK COUNTY--MAPS.

Tolman, Andrews L. Sand and gravel aquifers map 76 : Aroostook County, Maine. [Augusta] : Maine Geological Survey, 1980.

$M(211) 49$ sa56t no.76

Tolman, Andrews L. Sand and gravel aquifers map 79 : Aroostook County, Maine. [Augusta] : Maine Geological Survey, 1980.

M(211) 49 Sa56t no.79

Tolman, Andrews L. Sand and gravel aquifers map 78 : Aroostook County, Maine. [Augusta] : Maine Geological Survey, 1980. M (211) 49 Sa5bt no.78

Tolman, Andrews L. Sand and gravel aquifers map 84 : Aroostook County, Maine. [Augusta] : Maine Geological Survey, 1980.

$M(211) 49$ Sa 56 t no.84

Tolman, Andrews L. Sand and gravel aquifers, map 77 : Aroostook County, Maine. [Augusta] : Maine Geological Survey, 1980.

M (211) 49 Sa56t no.77 
Tolman, Andrews L. Sand and gravel aquifers map 85 : Aroostook County, Maine. [Augusta] : Maine Geological Survey, 1980. M (211) 49 Sa56t no.85

WATER, UNDERGROUND--MAINE--CUMBERLAND COUNTY--MAPS.

Caswell, W. Bradford Sand and gravel aquifers map 5 : Cumberland and York Counties, Maine. [Augusta] : Maine Geological Survey, 1979. M (211) 49 Sá56c no. 5

WATER, UNDERGROUND--MAINE--KENNEBEC COUNTY--MAPS. Sand and gravel aquifers map 17 : Kennebec County, Maine. [Augusta] : Maine Geological Survey, 1979.

M (211) 49 Sa56t no.17

WATER, UNDERGROUND--MAINE--LINCOLN COUNTY--MAPS.

Caswell, W. Bradford Sand and gravel aquifers map 9 : Lincoln and Knox Counties, Maine. [Augusta] : Maine Geological Survey, 1979. M (211) 49 Sá56c no.9

Sand and gravel aquifers map 18 : Lincoln, Knox, Waldo, and Kennebec Counties, Maine. [Augusta] : Maine Geological Survey, 1979. $M(211) 49$ Sa56t no.18

WATER, UNDERGROUND--MAINE--OXFORD COUNTY--MAPS.

Sand and gravel aquifers map 13 : Oxford, York, and Cumberland Counties, Maine. [Augusta] : Maine Geological Survey, 1979. M(211) 49 sa56C no.13

WATER, UNDERGROUND--MAINE--WALDO COUNTY--MAPS . Sand and gravel aquifers map 19: Waldo and knox Counties, Maine. [Augusta] : Maine Geological Survey, 1979. M(211) 49 Sa56t no.19

WATER, UNDERGROUND--MAINE--YORK COUNTY--MAPS. Caswell, W. Bradford. Sand and gravel aquifers map 3 : York County, Maine. [Augustaj : Maine Geological survey, 1979. M(211) 49 Sa56c no.3

Caswell, W. Bradford. Sand and gravel aguifer map 1 : York County, Maine. [Augustaj : Maine Geological survey, 1979. M (211) 49 Sa56c no.1

Sand and gravel aquifers map 4 : York and Cumberland Counties, Maine. [Augusta] : Maine Geological Survey, 1979. $M(211) 49$ Sa56c no.4

Tolman, Andrews L. Ground water resources of surficial aquifers map 1, York County, Maine. [Augusta] : Maine Geological Survey, 1982. $M(211) 49$ Y $82 t 1$

Tolman, Andrews L. Ground water resources of surficial aquifers map 2, york County, Maine. [Augusta] : Maine Geological Survey, 1982. $M(211) 49^{\circ}$ Y $82 \mathrm{t} 2$

Tolman, Andrews L. Ground water resources of surficial aquifers map 12, Cumberland, Androscoggin, and York Counties, Maine. [Augusta] : Maine Geological survey, 1982 .

M (211) 49 C912t 
Tolman, Andrews L. Ground water resources of surficial aquifers map 3, York County, Maine. [Augusta] : Maine Geological Survey, 1982. $M(211) 49$ y 82 t 3

Tolman, Andrews L. Ground water resources of surficial aquifers map 4, York and Cumberland Counties, Maine. [Augusta] : Maine Geological survey, 1982. $M(211) 49$ Y82tC

WATER, UNDERGROUND--MATHEMATICAL MODELS.

Sanford, ward E. A two-constituent solute-transport model for ground water having variabie density. [Reston, Va.] : U.S. Geological survey, 1985.

(200) WRi no.85-4279 D MP

WATER, UNDERGROUND--MINNESOTA--MINNEAPOLIS REGION--MAPS.

Wolf, Richard J. Hydrogeologic and water-quality characteristics of the Mount Simon-Hinckley aquifer, southeast Minnesota. St. Paul, Minn. : U.S. Geological survey, 1983 .

M (261) 49 H582W

WATER, UNDERGROUND--MISSISSIPPI--MAPS .

Darden, Daphne. Water-level maps of the alluvial aquifer northwestern Mississippi, April 1982. Jackson, Miss.: U.S. Geological Survey, 1982. M (236) 49 N818d

Darden, Daphne. Water-level maps of the alluvial aquifer northwestern Mississippi, September 1982. Jackson, Miss. : U.S. Geological Survey, 1983. M(236) 49 N818d Sept. 1982

Sumner, D. M. Water-level maps of the alluvial aquifer, Northwestern

Mississippi, April 1983. Jackson, Miss. : U.s. Geological Survey, 1984.

M (236) 49 N818s Apr. 1983

WATER, UNDERGROUND--NEVADA--LAS VEGAS SE QUADRANGLE--MAPS.

Harrill, James R. General ground water map, Las Vegas $S E$ quadrangle. Reno, Nev. : Nevada Bureau of Mines and Geology, 1980.

$M(275) 49 \operatorname{L3} 38 \mathrm{~h} 3$

WATER, UNDERGROUND--OREGON--MORROW COUNTY.

Norton, Marc $A$. Update of ground water conditions and declining water levels in the Butter Creek area, Morrow and Umatilla Counties, oregon. Salem, or.: State of oregon, Water Resources Dept., [1984]

$490(285)$ qor $33 \mathrm{~g}$ no.30

WATER, UNDERGROUND--PENNSYLVANIA--PHILADELPHIA.

Paulachok, Gary N. Temperature of ground water at Philadelphia, Pennsylvania, 1979-1981. Harrisburg, Pa.: U.S. Geological Survey, [1985?] (200) WRi no.84-4189 D MP

WATER, UNDERGROUND--PHILIPPINES--NEGROS ISLAND.

Quiazon, Hernando P. Geology and groundwater resources of Negros Island. Manila : Philippines Bureau of Mines and Geo-Sciences, [1983]

$402(920)$ qP55ri no.116

WATER, UNDERGROUND--POLLUTION.

Goláberg, V. M. Gidrogeologicheskie osnovy okhrany podzemnykh vod ot zagriazneni文. Moskva : Nedra, 1984. $494 \mathrm{G} 5649$ 
Kaplan, Paul G. Predicting the advective flow velocity in a confined aquifer using a single well tracer test. West Lafayette, Ind. : Water Resources Research Center, Purdue University, [1985]

S (252) qP972t no.171

WATER, UNDERGROUND--POLLUTION--CONGRESSES.

Degradation, retention and dispersion of pollulants in groundwater : proceedings of a specialised seminar of the IAWPRC held in Copenhagen, Denmark, 12-14 September 1984.1st ed. Oxford; New York : Pergamon Press, cl985.

795 P 944 v. 17 no.9

WATER, UNDERGROUND--POLLUTION--KANSAS

Spruili, T. B. Statistical evaluation of the effects of irrigation on chemical quality of ground water and base flow in three river valleys in north-central Kansas. Lawrence, Kan. : U.S. Geological Survey, 1985. (200) WRi no.85-4156 D MP

WATER, UNDERGROUND--PUERTO RICO--BARCELONETA REGION.

Torres-González, Arturo. Simulation of ground-water flow in the watertable aquifer near Barceloneta, Puerto Rico. San Juan, P.R. : U.S. Geological Survey, 1985. (200) WRi no.84-4II3 D MP

WATER, UNDERGROUND--PUERTO RICO.

Torres-González, Arturo. Use of surface-geophysical techniques for groundwater exploration in the Canovanas-Rio Grande area, Puerto Rico. San Juan, P.R. : U.S. Geological Survey, 1985. (200) WRi no.83-4266 D MP

WATER, UNDERGROUND--SOUTH CAROLINA--CLARENDON COUNTY.

Johnson, Phillip $W$. Reconnaissance of the ground-water resources of Clarendon and Williamsburg Counties, South Carolina. Columbia: The Commission, 1978 .

P (232) W292r no.13

WATER, UNDERGROUND--SWITZERLAND--BERN.

Grundlagen für Schutz und Bewirtschaftung der Grundwasser des Kantons Bern : Hydrogeologie Laufental. Bern [Switzerland]: Das Energiewirtschaftsamt, 1981 .

$490(53 \dot{5})$ qG925

WATER, UNDERGROUND--TENNESSEE-TOMBIGBEE WATERWAY REGION, MISS. AND ALA.

Morris, Fred. Hydrologic monitoring in the area of the Tennessee-Tombigbee Waterway, Mississippi-Alabama : fiscal year 1984. Jackson, Miss.: U.S. Geological Survey, \{1985 (200) R290 no.85-692

WATER, UNDERGROUND--TEXAS--COASTAL BEND AREA.

Groschen, G. E. Simulated effects of projected pumping on the availability of freshwater in the Evangeline aquifer in an area southwest of Corpus Christi, Texas. Austin, Tex. : U.S. Geological Survey, 1985. (200) WRi no.85-4182 D MP

WATER, UNDERGROUND--VICTORIA, AUSTRALIA--MELBOURNE REGION. Harris, I. F. Hydrogeology of the Melbourne region. [Victoria]: Mines Department, victoria, [1974?]

(830) qG292 no.1974/11 D 
WATER, UNDERGROUND--WASHINGTON (STATE) --SAN JUAN COUNTY--MAPS.

Whiteman, K. J. Occurance, quality, and use of ground water in orcas, San Juan, Lopez, and Shaw Isiands, san Juan County, washington. [Reston, Va.] : U.S. Geological Survey, 1983.

$M(284) 49$ or $2 w$

WATER USE--IDAHO--SNAKE RIVER VALLEY.

Goodell, S. A. Water use on the Snake River Plain, Idaho and eastern Oregon. Boise, Idaho : U.S. Geological Survey, 1986.

(200) R290 no.85-559 D MP

WATER USE--VIRGINIA.

Virginia water withdrawal and use report for 1982 and 1983. Richmond, Virginia: Virginia Water Control Board, [1985]

$P(227)$ qW292b no.54

WELLS--DESIGN AND CONSTRUCTION--HANDBOOKS, MANUALS, ETC.

Blankwaardt, Bob. Hand drilled wells : a manual on siting, design, construction and maintenance. Dar es Salaam : Rwegarulila water Resources Institute, 1984.

777 B6Ilh

WELLS--GEORGIA--WAYNE COUNTY.

Lohse, Alan. C. D. Hopkins et al. no. 2 geothermal well-of-opportunity, Wayne County, Georgia : operational report. [Washington] : Dept. of Energy, Division of Geothermal Energy ; Springfield, Va. : For sale by N.T.I. S., 1978.

$P(200)$ En27nvo no.1528-1

WESTERN AUSTRALIA--GEOLOGY--ADDRESSES, ESSAYS, LECTURES.

Professional papers for 1982. Perth : G.P.O., 1984.

(860) R no.12

WETLANDS--DELAWARE.

Tiner, Ralph W. Wetiands of Delaware. Dover, DE : The Department, [1985]

556 (224) T494W

WILDERNESS AREAS--CALIFORNIA.

Wilderness and areas of critical environmental concern in the California Desert Conservation Area : information document. [Sacramento, Calif.] : The staff, [1980]

$585.7(276)$ W646

WYOMING--GEOLOGY--INDEX MAPS .

DeBruin, Rodney H. Index map to U.S. Geological Survey miscellaneous investigations maps (I) in Wyoming. [Laramie, Wyo.] : Geological survey of Wyoming, 1983 .

M (282) $2051983 d i$

DeBruin, Rodney H. Index to selected U.S. Geological Survey Bulletins that contain geologic maps for Wyoming. [Laramie, wyo.] : Geological survey of Wyoming, 1984 .

$M(282) 2051984$ db

DeBruin, Rodney H. Index to selected U.S. Geological survey professional papers that contain geologic maps for Wyoming. [Laramie, Wyo.]: Geological survey of Wyoming, 1984.

M (282) 2051984 dp 
DeBruin, Rodney H. Index to U.S. Geological Survey miscellaneous field studies maps (MF) in Wyoming.Corrected 1984 ed. [Laramie, Wyo.] : Geological survey of Wyoming, 1984.

M(282) $2051984 \mathrm{dm}$

WYOMING--HYDROLOGY--INDEX MAPS.

DeBruin, Rodney H. Index to U.S. Geological Survey Hydrologic

investigations atlases (HA) in wyoming. Corrected $1984 \mathrm{ed.} \mathrm{ILaramie,}$ Wyo. ] : Geological survey of wyoming, 1984.

M (282) 78 i984dh

:

DeBruin, Rodney H. Index to U.S. Geological Survey hydrologic investigations at lases (HA) in Wyoming. [Laramie, Wyo.] : Geological survey of Wyoming, 1983.

M (282) 78 1983dh

WYOMING--MINERAL RESOURCES--FREMONT COUNTY.

Scott, David C. Mineral investigation of the Honeycomb Buttes study Area (WY-040-323). Fremont and Sweetwater Counties, Wyoming. [Washington, D.C.] : United States Department of the Interior, Bureau of Mines, 1985. $402(200)$ Un $34 \mathrm{msi}$ no.52-85

WYOMING--WATER-SUPPLY--INDEX MAPS.

DeBruin, Rodney H. Index to U.S. Geological Survey water-supply paper maps in Wyoming. [Laramie, Wyo.] : Geological survey of Wyoming, 1983.

$M(282) 781983 \mathrm{dw}$

ZAPISKI VSESOIUZNOGO MINERALOGICHESKOGO OBSHCHESTVA--INDEXES.

Grigoréva, T. A. Ukazatel' stateì ko vtoroì serii "Zapisok

Vsesoiuznogo mineralogicheskogo obshchestva," izdannykh s 1977 po 1981

god. Leningrad : Izdatelśkii otdel Biblioteki AN SSSR, 1983.

$G(570)$ R92 Index 1977-1981

ZINC ORES--NEVADA--MAPS.

Jones, Richard B. Zinc deposits and occurrences in Nevada. Washington, D.C. Williams and Heintz Map Corp.. 1984.

$M(275) 4351984 j$ 
Economics of the mineral industries : a series of articles by specialists. 4th ed., completely rev, and rewritten. New York : American Institute of Mining, Metallurgical, and Petroleum Engineers, 1985. 420 EC75 1985 MP

Ėksperimentalfaîa seísmologîîa v Uzbekistane. Tashkent : Izd-vo Fan Uzbekskoi SSR, 1983 .

240 (696) Ek78

A Geography of Hong Kong. Hong Kong ; Oxford : Oxford University Press, 1983. $503(611)$ G292

Geologists and ideas : a history of North American geology. Boulder, Colo. : Geological Society of America, 1985.

G(200) qG28C v.I

Geology of the San Jacinto Mountains. Santa Ana, Calif. : South Coast Geological Society, 1981.

$G(276)$ So86f no.9

A Guide to our federal lands / [compiled by National Geographic Society]. [Washington] : National Geographic Society, c1984.

R $585.7(200)$ G942

Issues in groundwater management. Austin, Tex. : The Center, 1985.

$784(245)$ W292 no.12

Map and description of the mineral deposits in the Juneau, Taku River, Atlin, and part of the Skagway quadrangles, Alaska. Menlo Park, Calif. : U.s. Geological Survey, 1986.

(200) R290 no.85-717 D MP

Mineral resource potential map of the northern part of the Washakie Wilderness and nearby roadiess areas, Park County, Wyoming. Reston, Va.: U.S. Geological Survey, 1985.

M (282) 4 W272a -- M(200) 4 vUn3mf no.1597-A -- M(200) MF no.1597-A

Mineral resources of the Eagle Mountain Wilderness Study Area, Pitkin County, Colorado. [Washington, D.C.] : U.S. G.P.O., 1986.

(200) E no.1717-B D MP F

Modern depositional environments of sands in South Texas. Corpus Christi, Tex. : The society, 1981.

$\mathrm{G}(245)$ qC81f 1981

ONWI Library reports list. Columbus, Onio : ONWI, Battelle Project Management Divisionl.

$P(200)$ En27onwi no.2+

Plankton studies in San Francisco Bay, VIII : chlorophyll distributions and hydrographic properties of south San Francisco Bay, 1983. [Menlo Park, Calif.] : U.S. Geological survey, Water Resources Division, [1985]

(200) R290 no.85-196 D MP 
Poiski i prognozirovanie sulfidnykh medno-nikelevykh mestorozhdenii : sbornik nauchnykh trudov. Leningrad : PGO "SEVMORGEOLOGIIA", 1982.

$426.2(690.3)$ P756

Preliminary geomagnetic data, College Observatory, Fairbanks, Alaska : January 1986. [Denver, Co] : U.S. Geological Survey, 1985.

(200) R290 no.86-300A D MP

A Survey of the physical properties of wheatland soils in eastern Australia. Australia : Commonwealth Scientific and Industrial Research Organization, 1985.

P (800) So34dr no.78

El terremoto de Andalucia de 25 de diciembre de 1884. Madrid : Presidencia del Gobierno, Instituto Geográfico Nacional, 1981.

$240(560)$ T2 77

Water quality modeling : hydrological and limnological systems, July, 1977 September, 1981, a bibliography with abstracts. Springfield, Va. : The Service, 1981.

042.797 qW292h

Water scarcity : impacts on western agriculture. Berkeley : University of California Press, c1984.

$790(270)$ W292

Aitkenhead, N. Geology of the country around Buxton, Leek and Bakewell : memoir for 1:50,000 geological sheet 111 (England and Wales). London : H.M. S.0. [for thel Natural Environment Research Council, 1985.

(520) BB986a

Battelle Memorial Institute. Office of Nuclear Waste-Isolation. Library. ONWI library reports list. Supplement. Columbus, $\mathrm{OH}$ : The Office.

$P(200)$ En270nwi no.2 Suppi.\#2+

Bergantino, R. N. Montana geologic atlas : Forsyth geology sheet. [Butte] : Montana Bureau of Mines and Geology ; [1977, i.e., 1980]

M (281) 2 F775b

Browning, Peter. Place names of the Sierra Nevada : from Abbot to Zumwalt. Berkeley, $C A$ : Wilderness Press, C1986.

$506(276)$ B8́22p

Chatman, Mark L. Mineral resources of the Buzzard Knob RARE II study area (No. 8-223), Rabun and Towns Counties, Georgia. Denver, Colo. : Intermountain Field Operations Center, U.S. Dept. of Interior, Bureau of Mines, 1985. $402(200)$ Un 34msi no. 56-85

Chatman, Mark L. Mineral resources of the Anna Ruby RARE II study area (No. 8225), White County, Georgia. Denver, Colo.: Intermountain Field Operations Center, U.S. Dept. of Interior, Bureau of Mines, 1985.

$402(200)$ ' Un34msi no. 57-85

DuMontelle, Paul B. Engineering geology of the greater Chicago area and the south shore of Lake Michigan. Chicago : Association of Engineering Geologists, [1979]

$G(200)$ qAs813́g 1979 
Fard, Mohammed Hossein Haschemi. Die Lagerstätten der Steine und Erden im ETeil des Grossraumes Hannover und inre wirtschaftsgeologische Bedeutung. 1977.

$453(530)$ F2231

Fodor, R. V. Earth in motion : the concept of plate tectonics. New York : Morrow, 1978.

311 F684e

Geological Survey (U.S.). Controlled photomosaic of part of the Maja Valles region of Mars. Reston, Va. : The Survey, 1985.

M (031) 5.1 M289g5 -- M(200) 2 vUn3m no.1695 -- M(200) I no.1695

Geological survey (U.S.). Controlled photomosaic of part of the Kasei Valles region of Mars. Reston, Va. : The Survey, 1985.

$M(031) 5.1$ KI52g -- M(200) 2 VUn3m no.1722 -- M(200) I no.1722

Geological Survey (U.S.). Controlled photomosaic of part of the Maja Valles region of Mars. Reston, Va. : The survey, 1985.

M (031) 5.1 M288g -- M(200) 2 vUn 3m no.1693-- M(200) I no.1693

Geological survey (U.S.). Controlled photomosaic of the Diacria Southwest quadrangle of Mars.Rev. 1984. Reston, Va. : The Survey, 1984.

$M(031) 5.1$ D542g1 -- M(200) 2 vUn 3m no.1598 - M (200) I no.1598

Geological Survey (U.S.). Controlled photomosaic of part of the Maja Valles region of Mars. Reston, va. : The Survey, 1985.

M (031) 5.1 M28894 -- M(200) 2 vUn 3̇m no.1694-- M(200) I no.1694

Geological survey (U.S.). Controlled photomosaic of the Maja Valles region of Mars. Reston, Va. : U.S. Geological Survey, 1985.

M (031) 5.1 M289g6 -- M(200) 2 vUn3m no.1716-- M (200) I no.1716

Geological survey (U.S.). Controlled photomosaic of part of the Mangala

Valies region of Mars. Reston, Va. : The Survey, 1985.

$M(031) 5.1$ M $31498--M(200) 2$ vUn3m no.1698 -- M(200) I no.1698

Geological Survey (U.S.). Controlled photomosaic of part of the Maja Valles region of Mars. Reston, Va. : The survey, 1985.

M (031) 5.1 M288gC -- M(200) 2 vUंn 3m no.1717-- M(200) I no.1717

Geological Survey (U.S.). Controlled photomosaic of part of the Maja Valles region of Mars. Reston, Va. : The Survey, 1985.

M (031) 5.1 M288g6 -- M(200) 2 vUn $3 \mathrm{~m}$ no.1676 -- M(200) I no.1676

Geological Survey (U.S.). Controlled photomosaic of part of the Maja Valles region of Mars. Reston, Va. : The Survey, 1985.

M (031) 5.1 M289g7 -- M(200) 2 vUn 3m no.1707-- M(200) I no.1707

Geological Survey (U.S.). Controlled photomosaic of part of the Mangala

Valles region of Mars. Reston, Va. : The Survey, 1985.

$M(031) 5.1$ M $31493-M_{(200)} 2$ vUn3m no. 1653 -. M(200) I no.1653

Geological Survey (U.S.). Controlled photomosaic of the Arcadia Southwest quadrangle of Mars.Rev. 1984. Reston, Va. : The Survey ; 1984.

$M(031) 5.1$ Ar22g1 -- M(200) 2 vUn $3 \mathrm{~m}$ no.1597 -. M(200) I no.1597 
Geological Survey (U.S.). Controlled photomosaic of part of the Maja Valles region of Mars. Reston, Va. : U.S. Geological Survey, 1985.

Geological Survey (U.S.). Controlled photomosaic of part of the valles Marineris region of Mars [experimental]. Reston, va.: The Survey, 1984. M (031) 5.1 V243gm -- M (200) 2 vUn3m no.1599 -- M(200) I no.1599

Geological Survey (U.S.). Controlled photomosaic of part of the Lunae Planum region of Mars (experimental) Reston, Va. : The survey, 1984. $M(031) 5.1$ P692g8 - M (200) 2 vUn3m no.1588 - M (200) I no.1588

Geological Survey (U.S.). Controlled photomosaic of part of the Mangala valies region of Mars. Reston, Va. : The Survey, 1985.

M (031) 5.1 M31497 - M (200) 2 vUn3m no.1697 - M (200) I no.1697

Geological survey (U.S.). Controlled photomosaic of part of the valles Marineris region of Mars. Reston, Va. : The Survey, 1984.

M (031) 5.1 V24393 -- M(200) 2 vUn3m no.1593 -- M(200) I' no.1593

Geological Survey (U.S.). Controlled photomosaic of part of the valles Marineris region of Mars [experimental]. Reston, va. : The Survey, 1984. M (031) 5.1 V243g9 -- M(200) 2 vUn3m no.1589 -- M(200) I no.1589

Geological survey (U.S.). Controlled photomosaic of part of the Lunae Planum region of Mars [experimental]. Reston, Va. : The survey ; 1984.

M (031) 5.1 P692g7 -- M(200) 2 vUn3m no.1587 -- M(200) I no.1587

Geological Survey (U.S.). Controlled photomosaic of part of the valles

Marineris region of Mars. Reston, Va. : The Survey, 1984.

M (031) 5.1 V243gI -- M (200) 2 vUn3m no.1591 -- M(200) I'no.1591

Geological Survey (U.S.). Controlled photomosaic of part of the valles

Marineris region of Mars [experimental). Reston, Va. : The Survey, 1984. M(031) 5.1 V243g -- M(200) 2 vUn3m no.1590 -- M(200) I no.1590

Geological Survey (U.S.). Controlled photomosaic of part of the Maja Valles region of Mars. Reston, Va. : The survey, 1985.

M (031) 5.1 M288gv -- M(200) 2 vUn 3m no.1718 - M(200) I no.1718

Geological Survey (U.S.). Controlled photomosaic of part of the valles Marineris region of Mars (Experimental). Reston, Va. : The Survey, 1984. M (031) 5.1 V243g2 -- M (200) 2 vUn3m no.1592 -- M(200) I no.1592

Geological Survey (U.S.). Controlled photomosaic of part of the Maja Valles region of Mars. Reston, Va. : The survey, 1985. M (03i) 5.1 M288gm -- M(200) 2 vUn $3 \mathrm{~m}$ no.1720 - M(200) I no.1720

Geological Survey (U.S.). Shaded relief map of the Casius quadrangle of Mars. Reston, Va. : The Survey, 1984. M (031) 5.1 C269g -- M(200) 2 vUn3m no.1646 -- M(200) I no.1646

Geological Survey (U.S.). Shaded relief map of the Lunae Palus quadrangle of Mars. Reston, va. : The Survey, 1984.

M(031) 5.1 L972g 1984 -. M(200) 2 vUn3m no.1511 -- M(200) I no.1511

Gillies, George T. The Newtonian gravitational constant : an index of measurements. Sèvres, France : Bureau international des poids et mesures, 1982 .

042.297 .5 G $415 \mathrm{n}$ 
Hamza, Cherif H. Zur Petrographie der Sesia-Zone im Bereich der Biellese Piemonteser Alpen. 1977. $150(550)$ H188z

Hillaire-Marcel, Claude. Stratigraphie de I'holocène et évolution des lignes de rivage au sud-est de la baie d'Hudson, Canada = Holocene stratigraphy $\varepsilon$ sea level changes in Southeastern Hudson Bay, Canada. Montréal : Laboratoire d'archeologie de I'UQAM, 1980.

$\mathrm{s}(140)$ C685 no.11

Hughes, G. W. Geology of the lower Itina Basin [microform]. Honiara : Solomon Islands Government, Ministry of Natural Resources, Geology Division, 1980 .

MICRO- FICHE (937) qB874 no.7

Johns, Willis M. Preliminary geologic map of the Kalispell lıpo isx $21 \mathrm{po}$ tsquadrangle. [Butte, Mont.]: Montana Bureau of Mines and Geology, 1980 $[i, e, 1982]$.

$M(28 i) \dot{2} \mathrm{~K} 125 j$

Johnson, William D. Geologic map of the Scott City quadrangle and part of the Thebes quadrangle, Scott and Cape Girardeau Counties, Missouri. Reston, Va. : U.S. Geological Survey, 1985.

M (263) 2 Sco84j -- M(200) 4 vUn 3mf no.1803 -- M(200) MF no.1803

Johnson, William D. Geologic map of the Morley quadrangle, Scott County, Missouri. Reston, Va. : U.S. Geological Survey, 1985.

M (263) 2 M827j - M (200) 4 vUn3mf no.1805 - M(200) MF no.1805

Kalugin, Ivan Aleksandrovich. Metamorfizm vulkanogenno-osadochnykh zheleznykh rud. Novosibirsk: Nauka, Sibirskoe otd-nie, 1985.

$G(690)$ Ak16t vyp.622

Kirstein, Dewey S. West Virginia mineral producers directory. 12 th ed. [Morgantown, w.Va.] : West Virginia Geological and Economic Survey, [1985] (228) qW3mr no.1 1985

Kongres geologa Jugoslavije (9th : 1978 : Sarajevo, Yugoslavia). Zbornik radova : IX Kongres geologa Jugoslavije. Sarajevo: The Odbor, 1978. $201(596) \mathrm{K} 837 \mathrm{z}$

Kretschmar, Ulrich. Talc, magnesite and asbestos deposits in the TimminsKirkland Lake area, Districts of Timiskaming and Cochrane. Ontario: Ministry of Northern Development and Mines, 1986.

$402(150)$ On82gc no.28

Look, Ernst-Rüdiger. Geologie und Bergbau im Braunschweiger Land : (Nordliches Harzvorland, Asse, Elm--Lappwald, Peine-Salzgitter, Allertal) : Dokumentation zur geologischen wanderkarte l:100 000. Hannover : Bundesanstalt fur Geowissenschaften und Ronstoffe; stuttgart: In Kommission, E. Schweizerbart, 1984.

(530.1) Aa Heft 78

Lowell, Thomas. Reconnaissance surficial geology of the Millinocket quadrangle, Maine. Augusta : Maine Geological Survey, 1981.

M (2li) 213 sq 
McAdam, A. D. Geology of the Haddington district : memoir for 1:50,000 sheet 33W and part of sheet 4I. London H.M.S.O., 1985.

(520) BHII7m

Miller, E. Willard (Eugene Willard). Pennsylvania--natural resources and economic development ; a bibliography. Monticello, Ill. : Vance

Bibliographies, [1985].

$R$ 042.030 P96 no.P-1819

Mines mid-year review. Mines mid-year review. Manila : The Division, 1976$402(920)$ P54mr

Moss, C. K. Aeromagnetic maps of the Mazatzal Wilderness and contiguous roadless areas, Gila, Maricopa, and Yavapai Counties, Arizona. Reston, Va. : U.S. Geological Survey, 1985.

M (274) 296 M456m -- M (200) 4 vUn3mf no.1573-B -- M (200) MF no.1573-B

Moss, C. K. Aeromagnetic maps of the Latir Peak and Wheeler Peak Wildernesses and the Columbine-Hondo Wilderness Study Area, Taos County, New Mexico. Reston, Va.: U.S. Geological Survey, 1985.

M (272) 296 L $348 \dot{m}$ - M (200) 4 vUn $3 \mathrm{mf}$ no.1570-C -- M (200) MF no.1570-C

Moyle, Phillip R. Mineral resources of part of the Whipple Mountains Wilderness study area (CDCA-312), San Bernardino County, California. Spokane, Washington : U.S. Dept. of the Interior, Bureau of Mines, Western Field Operations Center, 1985.

$402(200)$ Un $34 \mathrm{msi}$ no.39-85

Neubert, John T. Mineral investigation of the Worley Ridge RARE II area (08224), Rabun County, Georgia. Denver, Colo. : Intermountain Field operations Center, U.S. Dept. of Interior, Bureau of Mines, 1986. $402(200)$ Un $34 m s i$ no.6-86

New England Intercollegiate Geological Conference. Meeting (77th : 1985 : Yale University). Guidebook for fieldtrips in connecticut and adjacent areas of New York and Rhode Island : New England Intercollegiate Geological Conference, 77 th Annual Meeting, Yale University, October 4, 5, and 6, 1985. Hartford, CT :- State Geological and Natural History Survey of Connecticut, 1985.

(216) qGb no.6

Okhotnikov, VitaliI Nikolaevich. Granitoidy i rudoobrazovanie : polîannyi Ural. Leningrad : Nauka, Leningradskoe otd-nie, 1985.

$170(570)$ Ok2g

Open file (Geological survey of Canada). Open file. [Ottawa, Ont.] : The Survey.

(100) Op2

Outerbridge, William F. Opal claystone associated with phosphate rock in northern Saudi Arabia. [Reston, Va.] : U.S. Geological Survey, 1986. (200) R290 no.86-103 D MP

Perry, Stephen Kenneth. The geology of the Gebel Zeit region : Gulf of Suez, Egypt. Columbia, S.C. : Earth Sciences and Resources Institute, University of South Carolina, 1983. G(232) OC2 no.2 
Plescia, Jeffrey B. A bibliography of planetary geology principal investigators and their associates, 1981-1982. Washington, D.C. : National Aeronautics and Space Administration, Scientific and Technical Information Branch ; [Springfield, Va. : For sale by the N.T.I.S.], 1982.

$P(200)$ NA35cr no.3593

Pocknall, D. T. Palynological data from the Fort Union and Wasatch Formations, Powder River Basin, Wyoming and Montana. [Denver, CO] : U.S. Geological Survey, [1986]

(200) R29o no.86-117 D MP

Rains, Richard L. Mineral resources of the Worm Creek roadless study area, Bear Lake County, Idaho. Spokane, Washington : U.S. Dept. of the Interior, Bureau of Mines, Western Field Operations Center, 1985. $402(200)$ Un $34 m s i$ no. 59-85

São Paulo (Brazil : State). Programa de Desenvolvimento de Recursos Minerais. Mapa de jazidas e ocorrencias minerais do Estado de são Paulo : escala 1:500. 000: [São Paulo] : Governo do Estado de São Paulo, Secretaria da Indústria, Comércio, Ciência e Tecnologia, 1981.

M (410) 4 Sa64s

Schreiner, Russell A. Mineral resources of the Lower Burro Creek Wilderness study area (AZ-020-06099), Mohave and Yavapai Counties, Arizona. Denver, Colo. : Intermountain Field Operations Center, U.S. Dept. of Interior, Bureau of Mines, 1985.

$402(200)$ Un34msi no.51-85

Schubel, J. R. The living Chesapeake. Baltimore : Johns Hopkins University

Press, c1981.

$558(225)$ Sch $78 i$

Shane, Scott. Discovering Mount St. Helens : a guide to the National Volcanic Monument. Seattle : University of Washington Press, c1985. $585.7(284)$ Sh18d

South Africa's mineral industry. South Africa's mineral industry. Johannesburg : The Bureau.

$402(780)$ qM662s

Staatz, Mortimer Hay. Mineralogy of the microgranite at Jabal Tawlah, Kingdom of Saudi Arabia. [Reston, VA] : U.S. Geological survey, 1986.

(200) R290 no.86-io6 D MP

Stoeser, D. B. Reconnaissance geology of the Al Qasar quadrangle, sheet $27 /$ 4IC, Kingdom of Saudi Arabia. [Reston, VA] : U.S. Geological Survey, 1985. (200) R290 no.85-668 D MP

Symposium on the Geology and Mineral Deposits of the Challis lipotsx21p0ts Quadrangle, Idaho (1983: Spokane, Wash.). Symposium on the Geology and Mineral Deposits of the Challis lipo isx2,po tsquadrangle, Idaho: papers presented at the Northwest Mining Association Convention, Spokane, Washington, Dec. I-2, 1983. Washington : U.S. G.P.0., [1985]

(200) E no.1658A-S D MP F

United States. Bureau of Land Management. Legislative environmental impact statement for the Bureau of Land Management--Forest Service Interchange. Washington, D.C. : U.S. Bureau of Land Management, U.S. Forest ServiCe, [1986] $585.3(200)$ Un 321 
United States. National Bureau of Standards. NBS list of publications. Washington, D.C. : The Bureau.

$R$ P (200) C23ni

Vaccaro, J. J. Plan of study for the Regional Aquifer-System Analysis, Columbia Plateau, Washington, northern Oregon, and northwestern Idaho. Tacoma, Wash. : U.S. Geological Survey, 1986.

(200) WRi no.85-4151 D MP

Van, A. V. Vulkanoklasticheski i material vosadkakh i osadochnyk porodakh. Novosibirsk: Nauka, Sibirskoe otd-nie, 1985.

G(690) Akl6t vyp.614

Verband der Deutschen Höhlen- und Karstforscher e.V. Jahrestagung (2lst : 1979 : Ennepetal, West Germany). Fuhrer zu den Exkursionen der 21. Jahrestagung des Verbandes der deutschen Hohlen- und Karstforscher e.v. vom 19. bis 21. Oktober 1979 in..Ennepetal, Ennepe-Ruhr-Kreis. Munchen : Hrsg. v. Verband der deutschen Höhlen- und Karstforscher è.v., 1979.

$\mathrm{S}(530) \mathrm{K} 67 \mathrm{Nr} .18$

Welsh, Robert A. Mineral investigation of the Brasstown and Wolf Pen RARE II areas, Towns and Union Counties, Georgia. [Washington, D.C.] : U.S. Dept. of the Interior, Bureau of Mines, 1985.

$40(200)$ Un $34 \mathrm{msi}$ no.76-85

Yerbilimleri. Yerbilimleri : H. ̈̈. Yerbilimleri Enstitüsü yayın organı = Publication of Institute of Earth Sciences of Hacettepe University. Beytepe, Ankara : Enstitu. $G(680)$ Y $4 \dot{4}$

Zelten, Jeanne E. Mineral resources of the Browns Canyon wilderness study area (CO-050-002), Chaffee County, Colorado. [Washington, D.C.] : U.S. Dept. of the Interior, Bureau of Mines, 1985.

$402(200)$ Un $34 \mathrm{msi}$ no.70-85

ACID MINE DRAINAGE--MISSOURI.

Blevins, Dale $W$. Sources of coal-mine drainage and their effects on surface-water chemistry in the claybank Creek Basin and vicinity, northcentral Missouri, 1983-84. Rolla, Mo.: U.S. Geological Survey, 1986.

(200) R290 no.85-571 D MP

ACID RAIN--ENVIRONMENTAL ASPECTS--MATHEMATICAL MODELS.

Kislotnye dozhdi. Leningrad : Gidrometeoizdat, 1983.

583 K642

AERIAL PHOTOGRAPHY - TERMINOLOGY .

Shenkle, William. Glossary of photographic and reconnaissance terms.

Ohio: Wright Air Development Center, Air Research and Development Command, United States Air Force, Wright-Patterson Air Force Base, [1956]

$P(200)$ qDAi3tr WADC no.56-510

AEROSOLS--MEASUREMENT .

Kosmicheskoe distanṫ̀ionnoe zondirovanie atmosfernogo aérozolîa.

Leningrad : Gidrometeoizdat, 1983.

753.7 K847d 
ALGAE, FOSSIL--CONGRESSES.

International Symposium on Fossil Algae (3rd : 1983 : Colorado School of Mines, Golden, Colo.). Paleoalgology : contemporary research and applications. Berlin ; New York: Springer-Verlag, c1985. 697.1 In8f 1985

AMMONIA--ANALYSIS AND CHEMISTRY.

Sommers, Lee E. Chemical equilibria to model volatilization of ammonia from aquatic and soil systems. West Lafayette, IN : Water Resources Research Center, Purdue University, 1985.

$s(252)$ qP972t no.i75

AMMONOIDEA--ANGOLA--NOVO REDONDO.

Howarth, Michael Kingsley. Cenomanian and Turonian ammonites from the Novo Redondo area, Angola. London : British Museum (Natural History), [1985] $G(520)$ B $77 \mathrm{bg}$ v.39 no.2

AMPHIBOLITE--BRAZIL--MINAS GERAIS (STATE)

Schulz-Kunnt, Detlef. Petrographische Untersuchungen einer Zone amphibolitund granulitfazielier Gesteine im Raum Jequer.i, ostliches Minas Gerais, Brasilien. Hannover : Technischen Universitat clausthal, 1985. $190(410)$ Sch8p

ANGIOSPERMS, FOSSIL.

Pollens d'angiospermes du Tertiaire de I'Inde et leurs relations avec les pollens du Tertiaire d'Afrique $=$ Selected Tertiary angiosperm pollens from India and their relationship with African Tertiary pollens. Pondichéry [France] : Institut français de pondichéry, section scientifique et technique, 1984 .

$s(640)$ In8t $t .19$

Thanikaimoni, G. Ménispermacées : palynologie et systématique. Pondichéry [France] : Institut français de Pondichéry, Section scientifique et technique, 1984 .

$s(640)$ Inst $t .18$

AQUATRAIN PROJECT (U.S.).

Aquatrain corridor study report. [Denver, Colo.] : The Office, 1984. $461(270)$ Un36a MP

AQUIFERS--FLORIDA--ST. PETERSBURG REGION--MAPS.

Corral, M. A. Generalized thickness and configuration of the top of the intermediate aquifer, west-central Florida. Tallahassee, Fla. : U.S. Geological survey, 1984. M (234) 49 W522C 1984

AQUIFERS- -NEW YORK (STATE)--STEUBEN COUNTY--MAPS.

Geohydrology of the valley-fill aquifer in the Cohocton area, Upper Cohocton River, Steuben County, New York. [Ithaca, N.Y.]: U.S. Geological Survey, 1984 .

$M(221) 49$ C663t

ARCH DAMS.

Dynamic interaction effects in arch dams. Berkeley, Calif. : Earthquake Engineering Research Center, University of California ; Springfield, Va. ; for sale by the N.T.I.S., 1985. 240(276) Cl3ir no.85-il 
ARSENIC COMPOUNDS.

Kirkinskii, Vitalii Alekseevich. Knalkogenidy myshîaka, surmy i vismuta pri vysokikh davleniîkn. Novosibirsk : Nauka, Sibirskoe otdnie, 1985.

$G(690)$ Akl6t vyp.623

ASTRONAUTICS IN OCEANOGRAPHY

Maul, George A. Introduction to satellite oceanography. Dordrecht ; Boston : Martinus Nijhoff; Hingham, MA : Distributors for the U.S', and Canada, Kluwer Academic, 1985.

753.7 M443i

ATMOSPHERIC TEMPERATURE--NORTHERN HEMISPHERE.

Loginov, vladimir Fedorovich. Vulkanicheskie izverzheniîa i klimat. Leningrad : Gidrometeoizdat, 1984.

$511 \mathrm{~L} 828 \mathrm{v}$

ATMOSPHERIC WAVES.

Efimov, vladimir Vasilévich. Dinamika volnovykh proEsessov v pogranichnykh sloíakh atmosfery i okeana. Kiev : Nauk. dumka, 1981. $510(571)$ Ef63d

AVALANCHES.

Losev, K. S. Po sledam lavin. Leningrad : Gidrometeoizdat, 1983.

245 L897p

BAHAMAS--GEOLOGY.

Field guide to the geology of San Salvador. 3rd ed. San Salvador, Bahamas : CCFL Bahamian Field station, 1983. $203(395)$ F455

BASE MEASURING.

Basismessung Heerbrugg 1959, Beschlüsse und Anlage.: Arbeiten der Bodenseekonferenz. zurich : Schweizerische Geodätische Kommission, 1974 .

$752(535) \quad 9 B 292$

BATHOLITH--IDAHO--KETCHUM.

Hall, Wayne Everett. Eocene cauldron, batholith, and hydrothermal alteration west of Ketchum, Idaho. [Denver, Co] : U.S. Geological survey, 1986.

(200) R290 no.86-122 D MP

BAUXITE--SOLOMON ISLANDS--RENNELL ISLAND.

Winkler, Heinrich August. Bauxite prospects of Rennell Island, B.S.I.P. [microform] report. [Honiara] : Aerial Geophysical Surveys Project UNDP B.S.I.P. (1965-1968), 1968 .

MICRO- FICHE 753.7 (937) AI58r 1985

BENTHOS--CALIFORNIA--SAN FRANCISCO BAY.

Hopkins, Dale R. Atlas of the distributions and abundances of common benthic species in San Francisco Bay, California. [Reston, Va.]: U.S. Geological Survey, [1986]

(200) WRi no.86-4003 D MP

BIBLIOGRAPHY - - COAL.

Coal abstracts: user handbook, 1986. London : The Agency, 1986.

R 042.461 qC632u 1986 
BIBLIOGRAPHY--COAL--ALASKA.

Triplehorn, Julia H. Alaska coal : a bibliography. Fairbanks, Alaska : School of Mineral Industry, Mineral Industry Research Laboratory, University of Alaska, [1982]

$\mathrm{S}(286)$ qun $3 \mathrm{mr}$ no.51

BIBLIOGRAPHY--COUNCIL FOR MINERAL TECHNOLOGY (SOUTH AFRICA) •

Glen, H. W. Unrestricted Mintek publications, April 1984 to March 1985 [8th ed.]. Randburg, South Africa : Council for Mineral Technology, [1985] 044 (787) qG485u 1985

BIBLIOGRAPHY--HYDRAULIC ENGINEERING.

Peck, Rose Mary. List of publications of the U.S. Army Engineer Waterways Experiment station, [Dec. 1982]. Vicksburg, Miss. : U.S. Army Engineer Waterways Experiment Station, Technical Information Center, Special projects Branch, 1982 .

R P(200) WI26pi 1982

BIBLIOGRAPHY --HYDROLOGY--CANADA--PERIODICALS.

Bibliography (Canada. Inland Waters Directorate). Bibliographie $=$

Bibliography. Ottawa, ont. : The Directorate, 1985-

P (100) H995 v.10 no.2t

BIBLIOGRAPHY--WATER RESOURCES DEVELOPMENT--NEBRASKA.

Water resources publications related to the State of Nebraska. 5th ed. [Lincoln] : The Center, 1982 .

$S(266)$ qN24p no.7 Apr.1982

BIBLIOGRAPHY--WATER-SUPPLY--WYOMING .

Selected bibliography on water resources, State of Wyoming. Cheyenne, Wyo.: The Board, [1956]

$780(282)$ Se 48

BIBLIOGRAPHY --WATER, UNDERGROUND--MANAGEMENT .

Robinson, Patricia A. An annotated bibliography of local groundwater management publications. [Madison] : University of Wisconsin-Extension, $[1985]$

R 042.490 R565a

BIG THOMPSON RIVER, COLO.--FLOOD, 1976.

McComb, David G.' Big Thompson': profile of a natural disaster. Ist ed. Boulder, CO : pruett Pub. Co., c1980. $552(271)$ q́M134b

BIOCHEMICAL OXYGEN DEMAND--COMPUTER PROGRAMS.

Jennings, Marshall E. Determination of biochemical-oxygen-demand parameters. Bay St. Louis, Miss. : Water Resources Division, Gulf coast Hydroscience Center, $\{1976\}$ (200) J446d

BIOCHEMICAL OXYGEN DEMAND--MATHEMATICAL MODELS.

Stephens, Doyle $w$. Determination of primary productivity and community metabolism in streams and lakes using diel oxygen measurements. Bay st. Louis, Miss. : Water Resources Division, Gulf Coast Hydroscience Center, [1976\}

(200) St $44 d$ 
BLASTING ,

Stachura, Virgil J. Delayed blasting tests to improve highwall stability : a final report. Avondale, Md. : U.S. Bureau of Mines, 1986.

$402(200)$ Un34ex no. 9008

BOGS--ALASKA--KLATT BOG AREA.

Glass, R. L. Hydrologic conditions in the Klatt Bog area, Anchorage,

Alaska. Anchorage, Alaska : U.S. Geological Survey, 1986.

(200) WRi no.85-4330 D MP
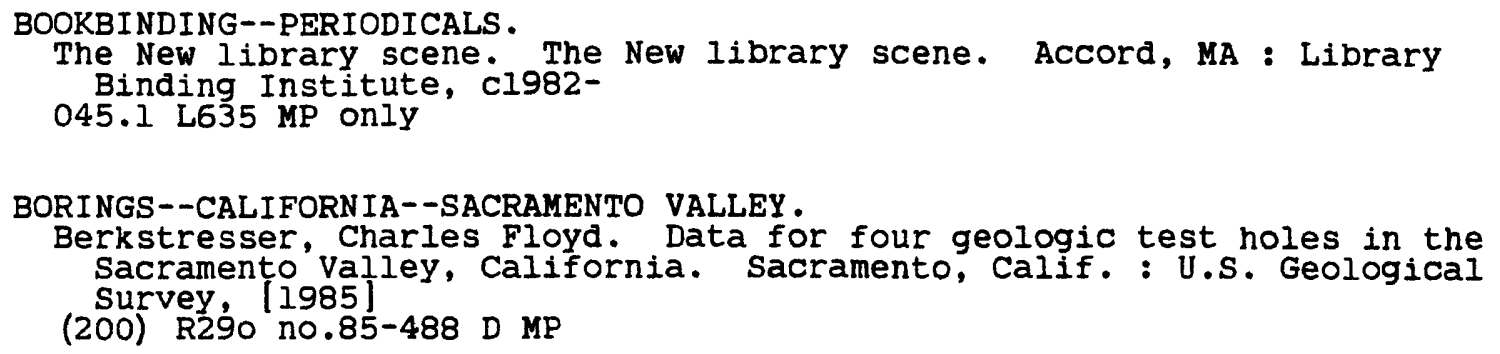

BORINGS-DATA PROCESSING.

Boger, Lewis W. Stratigraphic Analysis Techniques system (STRATS) user's manual. [Reston, VA]: U.S. Geological Survey, [1986]

(200) R290 no.86-102 D MP

BORINGS--OKLAHOMA.

Michalski, Thomas C. Catalog of Kansas and Oklahoma cores housed at the USGS Core Repository, Denver, Colorado. [Denver, Colo.] : U.S. Geological Survey, 1986 .

(200) R290 no.86-125 D MP

BORINGS--SOUTH DAKOTA--CATALOGS.

Michalski, Thomas C. Catalog of South Dakota cores housed at the USGS Core Repository, Denver, Colorado. [Denver, Co] : U.S. Geological Survey, 1986. (200) R290 no.86-89 D MP

BORINGS--UNITED STATES.

Prensky, stephen E. List of released wells and availability of digital well-iog data for Atlantic, Pacific and Alaska OCS regions through December 31, 1985. [Denver, Colo.]': U.S. Geological Survey, [1985]

(200) R290 no.86-48 D MP

BORINGS--UTAH--CATALOGS.

Michalski, Thomas C. Catalog of Utah cores housed at the USGS Core Repository, Denver, Colorado. [Denver, CO] : U.S. Geological Survey, 1986.

(200) R290 no.86-124 D MP

BOTANY--SIKHOTE ALIN MOUNTAINS.

Flora i rastitelhost'pribrezhnykh raionov iuga Dalfiego Vostoka. Vladivostok : Dalfevostochni nauchnyi Esentr AN SSSR, 1975. $928(691)$ F662 MP only

BRACHIOPODA, FOSSIL.

Sapelnikov, Vadim Petrovich. Sistema i stratigraficheskoe znachenie brakhiopod podotríada pentameridin. Moskva : Nauka, 1985. 652 Sa66s 
BRITISH GEOLOGICAL SURVEY--HISTORY.

Wilson, H. E. Down to earth: one hunared and fifty years of the British Geological survey. Edinburgh : Scottish Academic, c1985. (510) W694a

BUDGET--UNITED STATES.

United States. Congress. House. Committee on Appropriations. House of Representatives, Committee on Appropriations, views and estimates on the budget proposed for fiscal year 1987. Washington : U.S. Government Printing office, 1986.

P (200) C725ah

United States. Congress. House. Committee on Appropriations. House of Representatives, Committee on Appropriations, views and estimates on the budget proposed for fiscal year 1987. Washington: U.S. Government Printing office, 1986 .

$P(200)$ C725ahf

United States. Congress. House. Committee on Appropriations. The federal budget for 1987 : hearing before the Committee on Appropriations, House of Representatives, Ninety-ninth Congress, second session. Washington : U.S. G. P.O., 1986.

$P(200)$ C725fb

United States. Congressional Budget Office. A report to the senate and House Committees on the Budget, as required by Public law 93-344 : part II. Washington, D.C. : The Office : For sale by the Supt. of Docs., U.S. G.P.O., [1983]

P (200) C724rt

CALIFORNIA--GEOLOGY--OLD MAN MOUNTAIN QUADRANGLE--MAPS.

Dibblee, T. W. Geologic map of the Ôld Man Mountain quadrangle : Ventura and Santa Barbara Counties, California. Santa Barbara, Calif. : Thomas Wilson Dibblee, Jr. Geological Foundation, 1985.

$M(276) 2012 \mathrm{~d}$

CALIFORNIA--MINERAL RESOURCES--PIT RIVER CANYON WILDERNESS.

Sherlock, Maureen $G$. Mineral resources of the Pit River Canyon Wilderness Study Area, Lassen County, California. Washington, D.C.: U.S.G.P.O., 1986 .

(200) E no.1706-E D MP F

CANALS- -PAKISTAN.

ACOP canals equilibrium data : volume 10, summary of 1974-1980 data. Washington, D.C. : George Washington University, Civil, Mechanical and Environmental Engineering Department, [1984]

778 (648) AC72 V. 10

CANALS--WASHINGTON (STATE) --KING COUNTY--MAPS.

Chrzastowski, Michael J. Historical changes to Lake Washington and route of the Lake Washington ship Canal, King County, Washington. [Reston, Va.] : U.S. Geological Survey, 1983.

$M(284) 778$ LI48C - (200)'R290 no.81-1182 - (200) R290 no.81-1182

CARTOGRAPHY .

Aeronautical Chart and Information Center (U.S.). Map accuracy evaluation. St. Louis: Aeronautical Chart and Informatin Center, United States Air Force, 1962 .

$P(200)$ DAICr 
CARTOGRAPHY--COLLECTED WORKS.

Karlsruher geowissenschaftiiche Schriften. Reine A, Kartographie und Geographie.Karlsruher geowissenschaftliche Schriften. Reine A, Kartographie und Geographie. Karlsruhe : Fachhochschule Karlsruhe, Fachbereich Vermessungswesen und Kartographie, 1983-

S (530) K146gs

CARTOGRAPHY--DATA PROCESSING.

INPUT (Firm). Feasibility of marketing a digital cartographic data base. Palo Alto, California : INPUT, 1981.

759.5 gIn8f

CAVES--SPAIN .

La Sima 56, Picos de Europa-España. [S.1.] : Lancaster University Speleological society, 1985.

$547(560) \mathrm{Si} 38$

CAVING--CALIFORNIA--PERIODICALS.

Better caves and sinkholes of the Santa Barbara Underground Grotto. Better caves and sinkholes of the Santa Barbara Underground Grotto. Goleta, Calif.: The Grotto.

$S(276)$ B466

CAVING--PENNSYLVANIA--PERIODICALS.

PCC update (Pennsylvania Cave Conservancy). PCC update. Neffs, Pa.: The Conservancy.

$S(223)$ P384C

CAVING--WEST VIRGINIA--PERIODICALS .

Dead dog dispatch. Dead dog dispatch. Kearneysville, w.Va. : The Grotto, 1986-

$S(228) \quad D 338$

CENTRE FOR EARTH SCIENCE STUDIES, TRIVANDRUM--HISTORY.

Centre for Earth Science Studies, Trivandrum. Centre for Earth Science Studies : scope, structure, and projects. Trivanarum : The centre, [1979] $032(640)$ qc333c

CHALK--TEXAS--AUSTIN REGION.

Young, Keith. Austin chaik in its type area-- stratigraphy and structure. Austin, Tex. : Austin Geological Society, 1985.

G(245) G938 no.7

CHEMICAL RESEARCH--UNITED STATES.

National Research Council (U.S.). Committee to survey Opportunities in the Chemical Sciences. Opportunities in chemistry. Washington, D.C.: National Academy Press, 1985. $850.9 \times 2130$

CHEMISTRY, ANALYTIC--QUANTITATIVE.

Christian, Gary D. Analytical chemistry. 4th ed. New York : Wiley, cl986.

883 C463a

CHESAPEAKE BAY PROGRAM--YEARBOOKS

Chesapeake Executive Council. Annual progress report under the chesapeake Bay agreement. Annapolis, Md. : Chesapeake Bay Program Office, 1985$S(225)$ C424a 
CHROMITE--GREECE.

Knolke, Hermann. Petrographische, geochemische und experimentelle

Untersuchungen zur Umwandiung von Chromiten aus Vererzungen in Griechenland [microform]. 1985.

MICRO- FICHE 439(597) K756p

CHROMIUM INDUSTRY--SOVIET UNION.

Strishkov, Vasilii V. The chromium industry of the U.S.S.R. [Washington, D.C.?] : U.S. Dept. of the Interior, Bureau of Mines, [ig85]

$439(570)$ St86C

CIVIL SERVICE--UNITED STATES.

Rosen, Howard. Servants of the people : the uncertain future of the

Federal Civil service. Salt Lake City, Utah : Olympus Pub., c1985. $065.2(200)$ R723s MP

CLASSIFICATION--GOVERNMENT PUBLICATIONS.

Collins, Mae $S$. A practical guide to the superintendent of Documents classification system. Washington, D.C. : U.S. Government Printing Office, Superintendent of Documents, Library Programs Service, Classification and Cataloging Branch, [1986]

R P(200) qG746pg

CLIMATIC CHANGES--HAWAII.

Moberly, Ralph. Climate change and Hawaii : significance and recommendations. Honolulu : Hawaii Institute of Geophysics, University of Hawaii, [1985]

$\mathrm{S}(950) \mathrm{qH} 31 \mathrm{~h} \mathrm{~h}$ no.85-1

CLIMATOLOGY.

Understanding climate : a strategy for climate modeling and predictability research. Washington, DC : Scientific and Technical Information Branch, National Aeronautics and Space Administration; Springfield, Va. : For sale by the N.T.I.S., 1985.

$P(200)$ NA35rp no.i158

CLIMATOLOGY--STATISTICS--PERIODICALS.

Local Climatological data. Newark, New Jersey : annual summary with comparative data.Local climatological data. Newark, New Jersey : annual summary with comparative data. Asheville, N.C. : National Oceanic and Atmospheric Administration, National Environmental Satellite, Data and Information Service, National Climatic Data Center.

$P(200)$ NO24Ina

COAL--GEOLOGY--CHINA.

Takahashi, Nenji. On the main coal bearing seams of the Upper Paleozoic periods in the Yang-tzu-chiang Basin. Tokyo, Japan : U.S. Geological Survey, [1952]

209 (900)' qun33pr [no.492]

COAL--GEOLOGY--JAPAN--IBARAKI (PERFECTURE) .

Hatai, Kotora. Foundation of the Tertiary [of the Joban coal field]. [Tokyo, Japan] : U.S. Geological Survey, [1949]

$209(900)$ qUn33pr [no.433]

COAL--GEOLOGY--JAPAN--IBARAKI (PREFECTURE) .

Watanabe, Kyokichi. Tertiary stratigraphy of the Joban coal field.

[Tokyo, Japan : U.S. Geological Survey ; Pacific Geological surveys, 1939?]

$209(900)$ qun33pr [no.477] 
COAL--GEOLOGY--PENNSYLVANIA--INDIANA COUNTY.

Geologic processes affecting the quality of the upper Freeport coal bed, westcentral Pennsylvania. [Reston, VA] : U.S. Geological Survey, [1986]

(200) R29o no.86-173 D

COAL--ILLINOIS--DESULPHURIZATION.

Chou, Mei-In Melissa. Characterization of volatile sulfur compounds produced from Illinois coal chars. Champaign, IL : Illinois State Geological Survey, 1985.

(253) qIl6eg no.113

COAL LEASES--UNITED STATES.

Secretarial issue document : federal coal management program / [U.S. Department of the Interior]. [Washington, D.C.] : The Department, [1986]. $461(200) \mathrm{Se} 25$

COAL MINES AND MINING--ENVIRONMENTAL ASPECTS--MONTANA.

Montana. Dept. of State Lands. Consolidation Coal Company's CX Ranch mine, Big Horn County, Montana : final environmental impact statement. Helena, Mont.: Montana Dept. of State Lands ; [Denver, Colo.] : U.S. Office of Surface Mining, [1986]

$585.3(281)$ M752Cf

COAL MINES AND MINING--ENVIRONMENTAL ASPECTS--TENNESSEE--ROCK CREEK WATERSHED.

United States. Office of Surface Mining Reclamation and Enforcement. Rock Creek watershed, Tennessee petition evaluation document/environmental impact statement : draft : 522 SMCRA Evaluation OSMRE-PE-8 and Environmental Impact Statement OSMRE-EIS-22. Knoxville, TN : The Office, [1986]

$583.3(239)$ Un37rd

COAL MINES AND MINING--LAW AND LEGISLATION--MISSISSIPPI.

Mississippi. [Wasnington, D.C.] : U.S. G.P.O., 1985.

$421(236)$ M 692

COAL MINES AND_MINING--SAKHALIN (R.S.F.S.R.)

Nagai, Saburō. Survey report of Karafuto coal mining. Tokyo, Japan : The Branch, [1952]

$209(900)$ qun33pr [no.489]

COASTAL ENGINEERING--PERIODICALS.

The CERCular (Coastal Engineering Research Center (U.S.)). The CERCular. Vicksburg, Miss.: The Center, 1984-

$P(200)$ W124C

COASTAL ZONE MANAGEMENT--NORTH CAROLINA.

Striking a balance : reflections on ten years of managing the North Carolina coast. [Raleigh] : Division of Coastal Management, N.C. Dept. of Natural Resources and Community Development, 1985.

$521(231)$ st86

COASTS--CONGRESSES.

International Symposium on Coastal Evolution in the Holocene (1984 : Tokyo, Japan). Proceedings : International Symposium on Coastal Evolution in the Holocene, 1984, Tokyo, Japan. Tokyo, Japan : The Society, 1984.

354 In8p 1984 
COASTS--CONGRESSES--ABSTRACTS.

International Symposium on Coastal Evolution in the Holocene (1983: Tokyo, Japan). Abstracts of papers : International symposium on Coastal Evolution in the Holocene, August 29-31, 1983 Japan Tokyo, Japan. Tokyo : The Society, 1983.

354 qIn 8 a 1983

COBALT.

Foster, Russell J. Technological alternatives for the conservation of strategic and critical minerals--cobalt, chromium, manganese, and platinumgroup metals: a review. Washington, D.C.: U.S. Dept. of the Interior, Bureau of Mines: For sale by the Supt. of Docs., U.S. G.P.O., [1985] $402(200)$ Un $34 i$ ic no. 9054

COLOMBIA--GEOLOGY--MAPS.

Instituto Geológico Naçional (Colombia). Mapa geológico de la República de Colombia. [Bogotá] : Instituto Geológico Nacional, 1957-

$M(460) 2200$

COLORADO--MINERAL RESOURCES--BEAVER CREEK WILDERNESS.

Mineral resources of the Beaver Creek Wilderness Study Area, Fremont, El Paso, and Telier Counties, Colorado. [Washington, D.C.] : U.S. G.P.0., i986.

(200) E no.1716-B D MP F

CONDENSED MATTER--CONGRESSES.

European Physical Society. Condensed Matter Division. General conference (5th : 1985 : Technische Universitat, $W$. Berlin). 5th general conference of the Condensed.. Matter Division of the European Physical society, Technische Universität Berlin, 18-22 March 1985. [S.1.] : European Physical Society, c1985.

$\mathrm{s}(500)$ Eu 745 v.9A

CONNECTICUT--DESCRIPTION AND TRAVEL.

Bell, Michael. The face of Connecticut : people, geology, and the 1 and. Hartford, CT : State Geological and Natural History survey of Connecticut, 1985.

(216) C81b no. 110

CONNECTICUT--GEOLOGY--MAPS.

Rodgers, John. Bedrock geological map of Connecticut [Hartford] : Connecticut Geological and Natural History Survey, [1985].

$\mathrm{M}(216) 21985 \mathrm{r}$

CONSERVATION OF NATURAL RESOURCES--COLLECTED WORKS.

IES report (University of Wisconsin-Madison. Institute for Environmental Studies). IES report. Madison, Wis. : The Institute, 1973S (254) In 7

CONTINENTAL DRIFT--SAUDI ARABIA.

Stacey, J. S. U-PD isotopic evidence for accretion of a continental microplate in the Zalm region of the Saudi Arabian Shield. [Reston, Va.] : U.S. Geological survey, 1986. (200) R290 no.86-166 D MP

COPPER ORE--YUKON TERRITORY.

Sinclair, A. J. Geology of the White River native copper deposit, Yukon Territory. Whitehorse : Indian and Northern Affairs Canada, 1979. 203 (182) Si62g 
COPPER ORES--GEORGIA (TRANSCAUCASIA) .

Nazarov, IUrii I saakovich. Osobennosti formirovanita i prognoz

glubinnykh (skrytykh) mestorozhdenil mednokolchedannoi formatsii

IUtzhnoi Gruzii. Moskva : Nedra, 1966. $434(572) \mathrm{N} 2360$

CRYPTOEXPLOSION STRUCTURES--SIBERIA.

Tugovik, G. I. Fliúidno-eksplozivnye struktury $i$ ikh rudonosnost. Moskva : Nauka, 1984.

$410(690)$ T817f

CRYSTAL FIELD THEORY--CONGRESSES.

International Conference on Crystalline Field and Anomalous Mixing Effects in f-Electron Systems (5th : 1985 : Sendai, Japan). Proceedings of the 5 th International Conference on Crystalline Field and Anomalous Mixing Effects in f-Electron Systems : 15-18 April 1985, Sendai, Japan. Amsterdam : North-Holland, 1985.

$840 \mathrm{~J} 827$ v. 52 nós. $1-4$

CRYSTALLOGRAPHY--ADDRESSES, ESSAYS, LECTURES .

Problemy teoreticheskoi kristallokhimii slozhnykh oksidov. Leningrad : Nauka, Leningradskoe otd-nie, 1982.

$110 \mathrm{P9} 98$

CRYSTALLOGRAPHY--PICTORIAL WORKS.

Metz, Rudolf. Antlitz edler Steine : Mineralien, Kristalle. Stuttgart : Chr. Belser Verlag, c1978.

103 qM569a 1978

DAM FAILURES--WEST VIRGINIA--BUFFALO CREEK.

Seals, Roger K. Failure of Dam No. 3 on the middle fork of Buffalo Creek near Saunders, west Virginia on February 26,1972 : report. [Washington?] : Committee on Natural Disasters, National Academy of Engineering, 1972.

$768.3(228)$ Sel6f MP

DAMS--TESTING.

Vertical modal responses of Monticello Dam : results from an air-gun dynamic test. [Menlo Park, Calif.] : U.S. Geological Survey, 1985.

(200) R290 no.85-710 D MP

DEVILS TOWER NATIONAL MONUMENT.

United States. National Park Service. Rocky Mountain Regional office.

Final general management plan and development concept plan for Devils Tower

National Monument, Wyoming. [Washington, D.C.: U.S. G.P.O., 1986]

$585.7(282)$ Un $35 f$

DIAGENESIS.

Gautier, Donald L. Relationship of organic matter and mineral diagenesis. Tulsa, OK : SEPM, 1985.

G(200) Sol5sh no.17

DIAPIRS--TEXAS.

Jackson, M. P. A. Natural strain in diapiric and glacial rock salt, with emphasis on oakwood Dome, East Texas. Austin, Tex.: Bureau of Economic Geology, University of Texas at Austin, 1985.

(245) T7ri no.143 
DIGITAL MAPPING.

Loveland, Thomas R. Applications of U.S. Geological Survey digital

cartographic products, 1979-1983. Washington : U.S. G.P.O., 1986. (200) E no.1583 D MP F

DINOSAUR NATIONAL MONUMENT.

United States. National Park Service. Dinosaur National Monument : Moffat County, Colorado; Uintah County, Utah. [Washington, D.C.] : The Service, [1986] $585.7(270) \quad D 618$

DISPERSION .

Nordin, Carl F. Empirical data on longitudinal dispersion in rivers. Lakewood, Coio.: U.S. Geological Survey, [1974]

(200) WRi no.20-74 D MP

DIVING, SUBMARINE--ARCTIC OCEAN.

International Conference ICEDIVE ' 84 (Stockholm). Arctic underwater operations : medical and operational aspects of diving activities in Arctic conditions. London: Graham \& Trotman, 1985. $426(090)$ In8a

DRAINAGE--FLORIDA--DUVAL COUNTY--MAPS.

Stone, Roy B. Drainage basins in Duval County, Florida. Tallahassee, Fla. : U.S. Geological Survey, 1983.

M (234) 555 D956s

DREDGING--CATALOGS AND COLLECTIONS.

Description of W.H.O.I. rock dredge samples. Woods Hole, Mass. : Woods Hole Oceanographic Institution, 1981-

s(214) qW86t no.81-100t

DRINKING WATER--UNITED STATES--CONTAMINATION.

King, Jonathan. Troubled water : the poisoning of America's drinking water -how government and industry allowed it to happen, and what you can do to ensure a safe supply in the home. Emmaus, Pa. : Rodale Press, c1985. $797(200) \mathrm{K} 583 \mathrm{t}$

DRINKING WATER--UTAH--SALT LAKE COUNTY.

White, Megan J. A study of trihalomethane precursors in Deer Creek Reservoir. Logan, Utah : Utah Water Research Laboratory, Utah State University, [1985]

$S(273)$ Ut233w no.85-01

DRINKING WATER--UTAH--SALT LAKE COUNTY--CONTAMINATION.

Trihalomethane compounds and their precursors in Salt Lake County : evaluation of trihalomethane source and production. Logan, Utah : Utah Water Research Laboratory, Utan State University, [1984]

$S$ (273) Ut233w no.84-03

EARTH--CRUST--COLLECTED WORKS.

Hsien tai ti $k 0$ yun tung yen chiu. Hsien tai ti $k o$ yun tung yen chiu = Research on recent crustal movement. Pei-ching : Ti chen cht pan she, $1985-$

$P(610) \mathrm{K} 964 \mathrm{~h}$ 
EARTH--CRUST--MATHEMATICAL MODELS--ADDRESSES, ESSAYS, LECTURES.

Fiziko-mekhanicheskie protsessy i modeli tektonosfery Zemli. Moskva : Radio i sviaz', 1984 . $210 \mathrm{G} 283$ no. 7

EARTH CURRENTS--CZECHOSLOVAKIA--PRACHATICE--MEASUREMENTS.

Konečny, Mojmir. Results of geomagnetic and earth current measurements made at the observatory of Budkov in 1979. Prague : Academia, 1984. 296 (532) P952rE 1979

EARTH--INTERNAL STRUCTURE.

Continuum theories in solid earth physics. Amsterdam ; New York : Elsevier, 1986.

536 P568 v.3

EARTH RESISTANCE--MATHEMATICAL MODELS.

Newkirk, Deborah J. Downhole electrode, resistivity interpretation with three-dimensional models. Salt Lake City, Utan: Dept. of Geology and Geophysics, University of Utah, [1982] $P(200)$ En27nd

EARTH SCIENCES--ADDRESSES, ESSAYS, LECTURES.

The Making of the earth. Oxford [Oxfordshire]; New York, N.Y., USA : B. Blackwell, 1985. 315 M288

EARTH SCIENCES--CHINA--PERIODICALS.

Current topics in Chinese science. section F, Earth science. Current topics in Chinese science. Section F, Earth science. New York : Gordon and Breach, cl982-

$\mathrm{G}(610)$ C936

EARTH SCIENCES--COLLECTED WORKS.

Springer series in physical environment. Springer series in physical

environment. Berlin; New York : Springer-Verlag, cl985$582 \mathrm{Sp} 83$

EARTH SCIENCES--MATHEMATICAL MODELS.

Huggett, Richard J. Earth surface systems. Berlin; New York : SpringerVerlag, cl985.

582 Sp83 v.I

EARTH SCIENCES--PACIFIC REGION--COLLECTED WORKS.

Earth science series (Houston, Tex.). Earth science series. Houston, Tex. : The Council, 1985$203.2(080)$ Ea76

EARTH TEMPERATURE--SOVIET UNION--MAPS.

Smirnov, IA. B. Teplovoe pole territorii SSSR : poîasnitelhaîa

zapiska $k$ kartam teplovogo potoka i glubinnykn temperatur $v$ masshtabe 1:10 000 000. Moskva : Glavnoe upravlenie geodezii i kartografii pri sovete Ministrov SSSR, 1980.

$218(570)$ Sm48t MP only

EARTHOUAKE PREDICTION--CONGRESSES.

Proceedings of Practical Approaches to Earthquake Prediction and warning, Tokyo and Tsukuba, Japan, November 7-11, 1983. Dordrecht, Holland : D. Reidel Pub Co., cig85.

240.4 Ea76 v.3 no. 3-4 
EARTHQUAKE RESISTANT DESIGN.

Austin, M. A. A methodology for computer-aided design of earthquakeresistant steel structures. Berkeley, Calif. : Earthquake Engineering Research Center, University of California ; Springfield, Va. : for sale by the N.T.I.S. 1985 .

$240(276)$ Cl3ir no.85-13

EARTHQUAKES.

Cutchen, Billye W. Historical catastrophes--earthquakes. Reading, Mass. : Addison-Wesley Pub. Co., cl974. $240 \mathrm{C} 972 \mathrm{~h}$

Heck, Hans Dieter. Erdbenbengebiet Deutschland : an der Rissnaht Europas, Bebenursachen und -ablaufe. Stuttgart : Deutsche Verlags-Anstalt, 1980. $240(530)$ H355e

Physics of the earthquake focus = Fizika ochaga zemletryaseniya. New Delni : Published for the United States Department of the Interior, and the National Science Foundation, Washington, D.C., by American Printing Co. Pvt. Ltd., 1985. 240 F589E

EARTHQUAKES--CALIFORNIA--HOLLISTER REGION .

Preliminary report on records from the USGS-maintained strong-motion network in the Hollister area, January 26, 1986. [Menlo Park, Calif.] : U.S. Geological survey, [1986]

(200) R290 no.86-156 D MP

EARTHQUAKES--CAROLINE ISLANDS.

Musya, Kinkiti. Earthquakes that occurred in the Caroline Islands and vicinity. [Tokyo, Japan : U.S. Geological survey, Pacific Geological Surveys, 1949]

$209(900)$ qun33pr [no.486]

\section{EARTHOUAKES--CHILE.}

Seismic site-response experiments following the March 3, 1985 central Chile earthquake : topographical and geological effects. Menlo Park, Calif : U. S. Geological Survey, 1986.

(200) R290 no.86-90 D MP

EARTHQUAKES--NORTHEASTERN STATES--HISTORY--STATISTICS.

Epicenters of Northeastern United States and Southeastern Canada, onshore and offshore; time period 1534-1980. Albany, N.Y : The Universty of the State of New York, State Education Dept., 1983.

(22i) qN45mc no.38

EARTHQUAKES--OHIO--PAINESVILLE REGION.

Preliminary report on aftershock sequence for earthquake of January 31, 1986, near Painesvilie, Ohio (time period: $2 / 1 / 86-2 / 10 / 86$ ). [Menlo Park, CA] : U.S. Geological Survey, [1986]

(200) R290 no.86-181 D MP

EARTHQUAKES--SPAIN .

Mezcua, J. Sismicidad del area Ibero Mogrebi. Madrid : Instituto

Geografico Nacional, 1983.

240 qM578s MP 
ECLOGITE.

Udovkina, N. G. Éklogity SSsR. Moskva : Nauka, 1985.

$190(570)$ Uates

ECOLOGY--COLLECTED WORKS.

Walter, Heinrich. Ecological principles in global perspective. Berlin ; New York : Springer-Verlag, 1985.

919 WI720E

EIFEL (GERMANY) --DESCRIPTION AND TRAVEL--VIEWS.

Justra, Erich. Die Eifel im Farbbild. I0 überarbeitete und ergänzge Neuausgabe. Frechen-Konigsdorf : H. Ziethen, 1980.

$590(530)$ fJ986e 1980

ELASMOBRANCHII, FOSSIL.

Thies, Detlev. Jurazeitliche Neoselachier aus Deutschland und S-England = Jurassic Neoselachians from Germany and s-England. Frankfurt am Main : Courier Forschungsinstitut Senckenberg, 1982.

$\mathrm{s}(530)$ qF884C Nr.58

ELECTRIC PROSPECTING--MATHEMATICAL MODELS.

Sill, W. R. Self-potential effects due to hydrothermal convection-velocity crosscoupling. Salt Lake City, Utah : Dept. of Geology and Geophysics, University of Utah, [1982]

$P(200)$ En27ssp

ENERGY INDUSTRIES--AFRICA, SOUTHERN--ADDRESSES, ESSAYS, LECTURES.

Energy and development in southern Africa : SADCC country studies.

Stockholm, Sweden : Beijer Institute, Royal Swedish Academy of Sciences ; Uppsala, Sweden : Scandinavian Institute of African Studies, c1984. S (700) En27 no.3-4

ENERGY POLICY--SOVIET UNION .

Technology \& soviet energy availability : summary. Washington, D.C. :

Congress of the U.S., Office of Technoiogy Assessment, [1981]

$580(570)$ T226s

ENGINEERING GEOLOGY--SOVIET UNION.

Molokov, L. A. Inzhenerno-geologicheskie protsessy. Moskva : Nedra, 1985 .

$203.3(570)$ M736i

ENGLISH LANGUAGE--USAGE--DICTIONARIES.

Einstein, Charles. How to communicate : the Manning, Selvage $\&$ Lee guide to clear writing and speech. New York : McGraw-Hill, c1985.

053.2 Ei68h F only

ENVIRONMENTAL IMPACT STATEMENTS--MONTANA--BIG HORN COUNTY.

Consolidation Coal Company. Consolidation Coal Company's CX Ranch Mine, Big Horn County, Montana : final environmental impact statement. Helena : Montana Department of State Lands, [1986]

$585.3(281)$ C765cf

ENVIRONMENTAL IMPACT STATEMENTS--UNITED STATES--COLLECTED WORKS.

FERC/DEIA (United States. Office of Hydropower Licensing). FERC/DEIA. Washington, D.C. : The Office : [U.S.G.P.O.], 1984-

$P(200)$ En2ghfd 
FERC/EIA (United States. Office of Hydropower Licensing). FERC/EIA. Washington, D.C. : The Office, 1985-

$P(200)$ En29hfe

ENVIRONMENTAL POLICY--ASIA--CONGRESSES.

SAM Seminar on "Problems of Development, Environment, and the Natural Resource Crisis in Asia-Pacific" (1983 : George Town, Pinang).Environment, development \& natural resource crisis in Asia \& the Pacific: proceedings of the symposium. Penang, Malaysia : SAM, cl984.

$585.3(600)$ Sal8e

ESTUARINE SEDIMENTS--MASSACHUSETTS--BUZZARDS BAY.

Summerhayes, C. P. Estuaries as sinks for sediment and industrial waste : a case history from the Massachusetts coast. Stuttgart : Schweizerbart, 1985 .

$180 \mathrm{C} 768$ v.14

ETHIOPIA--GEOLOGY--OMO RIVER REGION.

Davidson, A. The Omo River Project : reconnaissance geology and geochemistry of parts of Ilubabor, Kefa, Gemu Gofa and Sidamo, Ethiopia. [Ottawa, Ont ;, Can.: s.n.], 1983.

(772) qB no. [3]

EVAPORATION (METEOROLOGY) .

Casebook on operational assessment of areal evaporation. Geneva, Switzerland : Secretariat of the World Meteorological organization, 1985. 510 w89opr no.22

EVOLUTION .

Eldredge, Niles. Unfinished synthesis : biological hierarchies and modern evolutionary thought. New York; Oxford : Oxford University Press, 1985. 915 E124u

EXPLOSIVES, MILITARY--ENVIRONMENTAL ASPECTS.

Leggett, Daniel $C$. Sorption of military explosive contaminants on bentonite drilling muas. [Hanover, N.H.] : US Army Corps of Engineers, Cold Regions Research \& Engineering Laboratory, [1985]

$P(200) \cdot D S 5 r$ no.85-18

EXTREME VALUE THEORY.

Leadbetter, M. R. On extreme values in stationary sequences, Chapel Hill : Dept. of Statistics, University of North Carolina, [1973]

$718 \quad 44720$

FACIES (GEOLOGY) --BRAZIL--FOZ DO AMASONAS BASIN.

Wolff, Breno. Microfacies, depositional environments ad diagenesis of the Amapá carbonates (Paleocene-midale Miocene), Foz do Amazonas Basin, offshore NE Brazil. Rio de Janeiro: Centro de Pesquisas e

Desenvolvimento Leopoldo A. Miguez de Mello, 1984.

467 (410) qP448ce no.13

FAULTS (GEOLOGY) --DATA PROCESSING.

Tiapkin, K. F. Izuchenie razlomnykh struktur geologo-geofizicheskimi metodami. Moskva : Nedra, 1982 .

276 T431i 
FAULTS (GEOLOGY) --JAPAN--SAGAMI BAY. Subbottom geological structures of Sagami Bay. Tokyo : Ocean Research Institute, [1984]

$S(620)$ T660b no.16

FAULTS (GEOLOGY) --MONTANA--GALLATIN COUNTY--MAPS.

Tysdal, Russell G. Geologic map of the Madison Roadless Area, Gallatin and Madison Counties, Montana. Reston, Va. : U.S. Geological Survey, 1985. M (281) 2 M265t - M (200) 4 vUn3mf no.1605-B - M (200) MF no.1605-B

FAULTS (GEOLOGY) --PACIFIC AREA--CONGRESSES .

Tectonostratigraphic terranes of the Circum-Pacific region. Houston, Tex., U.S.A.: Circum-Pacific Council for Energy and Mineral Resources, 1985 . $203.2(080)$ qEa76 no.1

FEYNMAN, RICHARD PHILLIPS.

Feynman, Richard Phillips. "Surely you're joking, Mr. Feynman!" : adventures of a curious character. New York : $\mathbf{w} . W$. Norton, c1985. 081 F438f

FISHES, FOSSIL.

Gardiner, Brian George. Devonian Palaeoniscid fishes : new specimens of Mimia and Moythomasia from the Upper Devonian of Western Australia. Berkeley : University of California Press, 1984. $671(860)$ G168d

FLOOD FORECASTING--MATHEMATICAL MODELS.

Boorman, D. B. A review of the flood studies report rainfall-runoff model parameter estimation equations. [Wallingford, England] : Institute of Hydrology, [1985] $S(520)$ qR298 no.94

FLOODS.

Brown, Walter R. Historical catastrophes : floods. Reading, Mass. : Addison-Wesley, cl975.

$552 \mathrm{~B} 816 \mathrm{~h}$

FLOODS--PUERTO RICO--UTUADO--MAPS.

Johnson, Karl G. Flood of September 16, 1975 at Utuado, Puerto Rico.

San Juan, PR : Geological Survey, Caribbean District, [1981].

M (394) 552 Ut $8 j$-- (200) R290 no.81-413 -- (200) R290 no.81-413

FLUID INCLUSIONS.

Shepherd, T. J. A practical guide to fluid inclusion studies. Glasgow : Blackie; New York : Distributed in the USA by Chapman and Hall, 1985. $298.4 \operatorname{Sh} 48 \mathrm{p}$

FLUORESCENCE SPECTROSCOPY.

Balaes, André Marie Eloi. The determination, by $x$-ray-fluorescence spectrometry, of tin and zinc in ores, middlings, and residues (laboratory method no. 30/16). Randburg, South Africa : Council for Mineral Technology, 1984 .

$\mathrm{s}(787)$ qN2I3r no.Mi46

FLUORSPAR.

Kilgore, Catherine C. Fluorspar availability--market economy countries and China : a minerals availability appraisal. Avondale, MD : U.S. Dept. of the Interior, Bureau of Mines, 1985.

$402(200)$ Un34ic no.9060 
FOLDS (GEOLOGY).

Shevchenko, $V$. I. Proiskhozhdenie struktur gorizontalhogo szhatîa $v$ skladchatom sooruzhenii : na primere Bolśnogo Kavkaza. Moskva : Nauka, 1984 .

$276(570)$ Sh58p

FORAMINIFERA, FOSSIL--ALASKA--PRUDHOE BAY.

McDougall, Kristin A. Micropaleontology and sedimentology of the PB

borehole series, Prudhoe Bay, Alaska. Washington : U.S. G.P.O., 1986.

(200) E no.1598 D MP

FORAMINIFERA, FOSSIL--KRYMSKAIA OBLAST" (UKRAINE) .

KuzneÉsova; $K$. I. Stratigrafi住 $i$ foraminifery verkhnei iury i nizhnego mela Kryma. Moskva : Nauka, 1985.

$G(570)$ AC122g2p vyp.395

FORAMINIFERA, FOSSIL--NORWAY .

Sejrup, Hans Petter. Senkvartaere mollusker og foraminiferer fra vestnorge og kontinentalmarginen utenfor. Bergen : Universitetet, 1982.

$689.6(581)$ qSe46s

FOUNDATIONS--COLLECTED WORKS.

Veroffentlichungen des Institutes für Grundbau, Bodenmechanik, Felsmechanik und Verkehrswasserbau der RWTH Aachen. Veroffentlichungen des Institutes fur Grundbau, Bodenmechanik, Felsmechanik und Verkehrswasserbau der RWTH Aachen. Aachen : Das Institut.

$S(530)$ P963

FRESHWATER BIOLOGY--ERIE, LAKE--CONGRESSES.

Conference on Changes in the Biota of Lakes Erie and ontario (1980 : Buffalo, N.Y.) . Proceedings of the Conference on Changes in the Biota of Lakes Erie and Ontario : March 10-11, 1980. Buffalo, N.Y. : Buffalo Society of Natural Sciences, 1981.

$\mathrm{S}(221)$ B89 v.25 no.4

GALILEO PROJECT.

Galileo : expioration of Jupiter's system. Washington, D.C. : Scientific and Technical Information Branch, National Aeronautics and Space Administration : for sale by the supt. of Docs., U.S. G.P.O., 1985. $P(200)$ NA35sp no.479

GAS INDUSTRY--STATISTICS--PERIODICALS.

Oil \& gas journal data book. Oil \& gas journal data book. Tulsa, Okla. : Pennwell Books, c1985-

$s(200) 0 i 5 g$

GASTEROPODA--SOVIET UNION.

Golikov, A. N. Rakovinnye brîukhonogie mollîuski litorali moreĭ SSSR.

Leningrad : Nauka, Leningradskoe otd-nie, 1978.

$986(570)$ G582r MP only

GEOCHEMICAL PROSPECTING.

Geokhimicheskie kriterii poiskov medno-nikelevykh mestorozhdenil.

Leningrad : Nedra, Leningradskoe otd-nie, 1982.

426.2 G292k MP only 
Grigoriân, Sergei vagarshakovich. Vtorichnye litokhimicheskie oreoly pri poiskakh skrytogo orudeneni ia. Moskva : Nauka, 1985. $426.2 \mathrm{G} 877 \mathrm{v}$

Tenîakov, V. A. Paleogeograficheskie i geoknimicheskie kriterii prognozirovania mestorozhdenii boksitov. Moskva : Nedra, 1985. 426.2 T263p

GEOCHEMICAL PROSPECTING--ALASKA--UNGA ISLAND REGION.

Angeloni, Linda $M$. Map and tables showing preliminary rock geochemical data, Port Moller, Stepovak Bay, and Simeonof Island quadrangles, Alaska. [Menio Park, CA] : U.S. Geological Survey, 1985.

(200) R290 no.85-470 D MP

GEOCHEMICAL PROSPECTING--ARGENTINA--CORDOBA (PROVINCE) .

Geoguimica de las plutonitas en la Sierra de los Gigantes, Provincia de Cordoba, República Argentina : fenomenos relacionados con la distribucion del uranio. [S.1.]: Argentina, Comisión Nacional de Energía Atómica, Gerencia de Materias Primas, 1975.

426.2 (420) qG292

GEOCHEMICAL PROSPECTING--CALIFORNIA--ALPINE COUNTY--MAPS.

Chaffee, Maurice A. Summary geochemical map for samples of rock, stream sediment, and nonmagnetic heavy-mineral concentrate, Freel and Dardanelles Roadless Areas, Alpine and EI Dorado Counties, California. Reston, Va. : U.S. Geological Survey, 1985 .

$M(276) 426.2$ F875C -- M(200) 4 vÜn3mf no.1322-D -- M(200) MF no.1322-D

GEOCHEMICAL PROSPECTING--COLORADO--CLEAR CREEK COUNTY--MAPS.

Barton, H. N. Geochemical maps showing the distribution and abundance of selected elements in heavy-mineral concentrates from ridgetop soils from the Williams Fork Roadless Area, Clear Creek, Grand, and Summit Counties, Colorado. Reston, Va.: U.S. Geological Survey, 1985.

$M(271) 426.2$ W672b $-\therefore$ M (200) 4 vUn $3 m f$ no.1588-I -- M (200) MF no.1588-I

GEOCHEMICAL PROSPECTING--CONGRESSES.

International Geochemical Exploration Symposium (loth : 1983 : Helsinki, Finland). Ioth International Geochemical Exploration Symposium : 3rd Symposium on Methods of Geochemical Prospecting ; 10th IGES--3rd SMGP : Espoo/Helsinki, Finland, August 29 to September 2, 1983 : [abstracts]. Helsinki : Geological Survey of Finland, 1983.

426.2 In 8 ta

GEOCHEMICAL PROSPECTING--IDAHO--CUSTER COUNTY--MAPS.

Geologic and geochemical map of Jerry Peak West and Boulder Creek Wilderness Study Areas, Custer County, Idaho. Reston, Va. : U.S. Geological Survey, 1984.

M(283) 2 J485m -- M(200) 4 vUn3mf no.1466-E -- M(200) MF no.1466-E

GEOCHEMICAL PROSPECTING--SOVIET UNION.

Pitulko, Viktor Mikhailovich. Litoknimicheskie metody sémki i poiskov. Leningrad : Nedra, Leningradskoe otd-nie, 1985.

426.2 (570) P6்71

GEOCHEMICAL PROSPECTING--WASHINGTON (STATE) --KING COUNTY--MAPS .

Geochemical maps of the Eagle Rock and Glacier Peak Roadless Areas, Snohomish and King counties, Washington. Reston, Va. : U.S. Geological Survey, 1985.

$M(284) 426.2$ Ea36C -- M(200) 4 vUn $3 \mathrm{mf}$ no.1380-D -- M(200) MF no.1380-D 

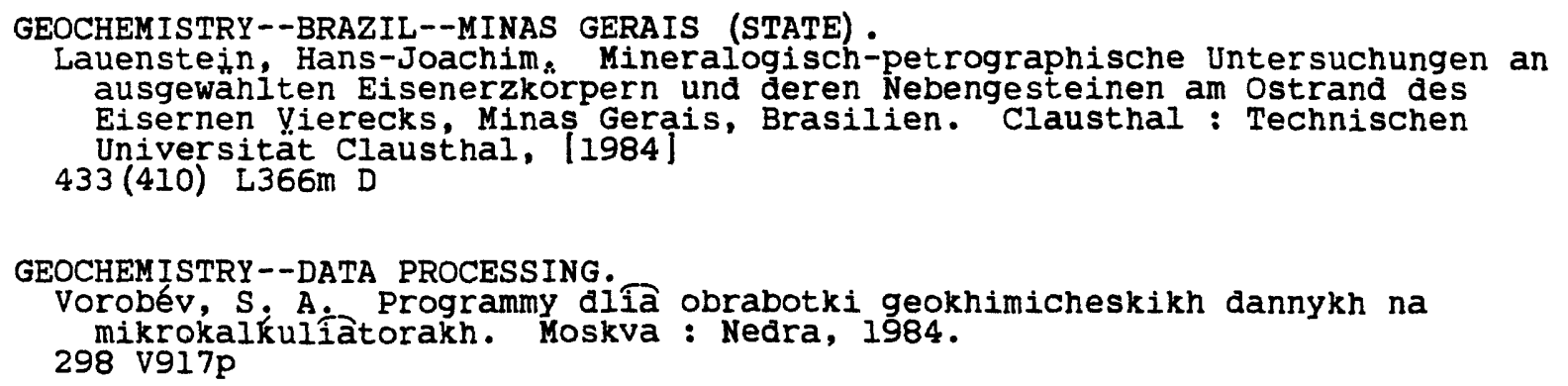

GEOCHEMISTRY--HIMALAYA MOUNTAINS--ADDRESSES, ESSAYS, LECTURES.

Geochemistry, petrochemistry, petrology, mineralogy, sedimentology, geomorphology, metallogeny and geotechnical study. Dehra Dun, India : Bishen Singh Mahendra Pal Singh, 1983.

G (540) qC767 v.2
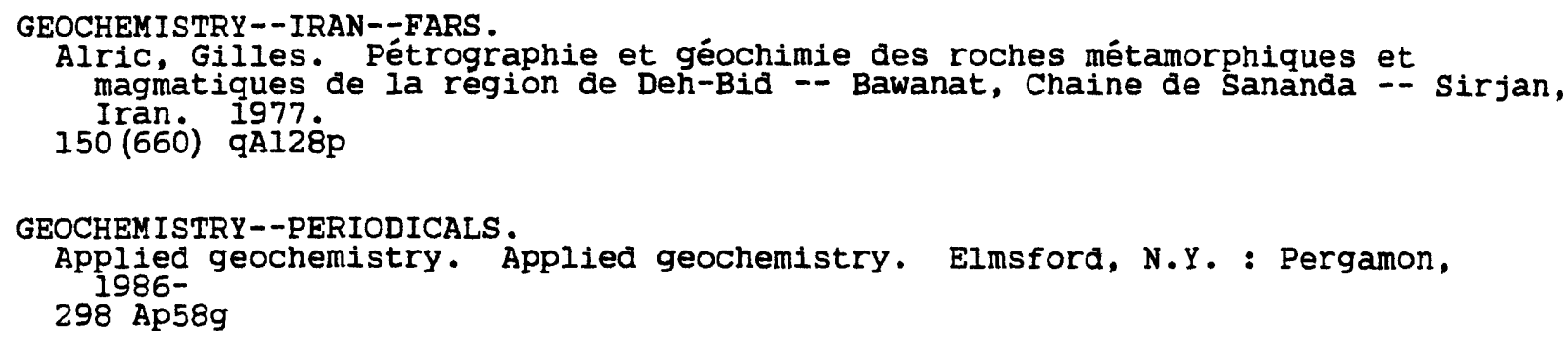

GEOCHEMISTRY--VIRGIN ISLANDS OF THE UNITED STATES.

Analytical results from a geochemical survey of the U.S. Virgin Islands. [Denver, CO]: U.S. Geological Survey, 1986 .

(200) R290 no.86-86 D MP

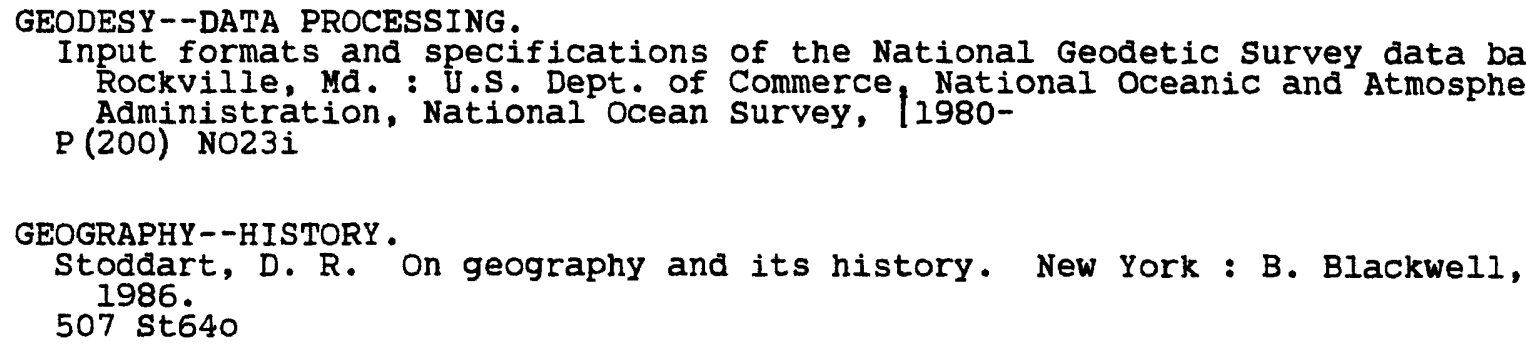

GEOGRAPHY--PERIODICALS.

Majallah. Majallah. Baghdād : Jamīyan al-Jughrāfīyah alIrágiyan.

s $(665)$ M 288

GEOLOGICAL MAPPING--CAUCASUS.

Krupnomasshtabnoe geologicheskoe kartirovanie metamorficheskikn formaEsil na primere Kavkaza : metodicheskie ukazaniia. Tbilisi : Metsniereba, 1985.

$\mathrm{G}(570) \mathrm{T} 44 \mathrm{tn}$ no.87 
GEOLOGICAL RESEARCH--CANADA.

Bolton, Thomas Edward. Current research in the geological sciences in Canada, May 1984-April 1985 = Travaux en cours dans le domaine des sciences géologiques au Canada, de mai 1984 a avril 1985. Ottawa : Published for the Council by the Geological survey of Canada, 1985.

(100) qP no.85-5

GEOLOGICAL SOCIETY OF IOWA--PERIODICALS.

Geological Society of Iowa. Newsletter. Iowa City : Iowa Geological Survey.

(262) $\mathrm{N} 477$

GEOLOGICAL SURVEY (U.S.) . WATER RESOURCES DIVISION.

Geological Survey (U.S.). Water Resources Division. Training manual for technicians : phase I. [S.I.] : The Division, 1968.

(200) qWR3t

GEOLOGICAL SURVEYS.

Yamashima, Sadao. Geological Survey report by the East Party of the First Swampy Land Survey to north Manchuria. Tokyo, Japan : U.S. Geological Survey, [1953]

209 (900)' qun33pr [no.491]

GEOLOGISTS--TEXAS--HOUSTON--DIRECTORIES.

Houston Geological Society. Membership directory, Houston Geological Society. Houston : The Society.

R $056.2(245)$ H818d

GEOLOGY--CONGRESSES.

Conference on Results of the Cooperative Research in Geosciences between the Central office of Geology of Hungary $(\mathrm{KFH})$ and the United States Geological Survey (1984 : Budapest, Hungary). Cooperative research in the geosciences between the U.S. Geological Survey (USGS) and the Central office of Geology (KFH) during 1978-84 : proceedings of a joint conference, 1-3 October 1984, Budapest, Hungary. TReston, Va.] : The Survey, 1985.

(200) R290 no.85-291

GEOLOGY--DATA PROCESSING.

Davis, Jonn C. Statistics and data analysis in geology. 2nd ed. New York : Wiley, cl986.

209 D294s 1986 D MP

GEOLOGY, STRATIGRAPHIC.

Enrione LI., Alfredo. Geology of the area of the "El Toro" hydroelectric plant Lago Laja, Nuble Province. Santiago, Chile : Instituto de Investigaciones Geológicas, Sección Geologla Aplicada a la Ingenieria, [1963]

$203(430)$ En73g

Enrione LI., Alfredo. Geology of the proposed site for the "El Toro" hydroelectric plant, the terminal part of the Lago Laja Tunnel and penstock alinements, province of Nuble. Santiago, Chile : Instituto de Investigaciones Geológicas, Sección Geología Aplicada a la Ingeniería, [1963]

$203(430)$ En73gp 
Enrione, Ll., Alfredo. Reconnaissance geology of the Alto Polcura diversion project area, N̂ble province, Chile. Santiago, Chile: Instituto de Investigaciones Geológicas, [1964]

$203(430) \operatorname{En} 73 r$

Graveson, Peter. Guide to excursion in Bornholm : 8th annual working meeting in Sweden and Denmark of Project Tornquist/Southwest border of the EastEuropean Platform 1982, IGCP Project no. 86. Copenhagen : Geological Survey of Denmark, 1984

(585) qG8sc no.3

Yang, Tsun-i. The Geology of China. Oxford ; New York : Clarendon Press, 1986 .

$210(610) \mathrm{Yal6g}$ MP

GEOLOGY, STRATIGRAPHIC--ARCHAEAN .

Lavreau, J. Etude géologique du Haut-Zaïre : genèse et évolution d'un segment iithosphérique archéen. [Tervuren, Belgique: Musée royal de I' Afrique centrale, 1982]

$G(593)$ T27ag no.88

GEOLOGY, STRATIGRAPHIC--CARBONIFEROUS.

Beitrảge zur Tiefentektonik des Ruhrkarbons. Krefeld: Geologisches Landesamt Nordrhein-Westfalen, 1980.

$336(530)$ qB397

Gjelberg, John. Early-Middle Carboniferous sedimentation on Svalbard : a study of ancient alluvial and coastal marine sedimentation in rift and strikeSlip basins. 1984.

$336(581)$ qG448e

GEOLOGY, STRATIGRAPHIC--CENOZOIC--MAPS.

Helley, Edward J. Geologic map of the Late Cenozoic deposits of the Sacramento Valiey and Northern Sierran Foothills, California. Reston, Va. : U.S. Geological Survey, 1985.

M(276) 35 Sal4h -- M(200) 4 vUn3mf no.1790 -- M(200) NF no.1790

GEOLOGY, STRATIGRAPHIC--DEVONIAN .

Devonian and Pennsylvanian stratigraphy of the Quad Cities Region, IIIinoisIowa : September 21, 1985, Augustana College, Rock Island, Illinois. [S.1.] : Society of Economic Paleontologists and Mineralogists, Great Lakes Section, $[1985$ ? $]$

$G(250)$ Solsglaf no. 15

McCrossan, R. G. Upper Devonian inter-reef calcareous shales of central Alberta, Canada. Chicago, Ill. : University of Chicago, Dept. of Geology, 1957

$335(170)$ qM138u

GEOLOGY, STRATIGRAPHIC--HOLOCENE--ABSTRACTS .

Palaeohydrology of the temperate zone in the last 15,000 years : abstracts : Mikulcice, Czechoslovakia, 24-28 September 1984. Mikulcice : IGCP, I984.

364 (500) P176

GEOLOGY, STRATIGRAPHIC--JURASSIC.

Levchuk, Mikhail Antonovich. LitologiTa $i$ perspektivy neftegazonosnosti iurskikh otlozhenii Enisei-Khatangskogo progiba. Novosibirsk : Nauka, Sibirskoe otd-nie, 1985.

G (690) Akl6t vyp.624 
GEOLOGY, STRATIGRAPHIC--JURASSIC--CONGRESSES .

Society of Economic Paleontologists and Mineralogists. Gulf Coast Section. Foundation Research Conference (3rd: 1982 : Bàton Rouge, La.). The Jurassic of the Gulf rim. [Austin, Tex. : The Section, ig82] G (200) G954p 1982

GEOLOGY, STRATIGRAPHIC--MIOCENE.

Morton, Robert A. Depositional history, facies analysis, and production characteristics of hydrocarbon-bearing sediments, off shore Texas. Austin, Tex. : Bureau of Economic Geology, University of Texas at Austin, 1985. (245) qT7gc no.85-2

GEOLOGY, STRATIGRAPHIC--NOMENCLATURE--UNITED STATES.

Luttrell, Gwendolyn Lewise Werth. Lexicon of new formal geologic names of the United States, 1976-1980. [Washington, D.C.] : U.S. G.P.O., 1986.

(200) E no.1564 D MP F

GEOLOGY, STRATIGRAPHIC--OLIGOCENE.

Báldi, Tamás. Magyarországi oligocén és alsómiocén formációk. Budapest : Akademiai Kiadó, 1983.

$351(534)$ B193m

GEOLOGY, STRATIGRAPHIC--ORDOVICIAN .

Rozova, A. V. Stratigrafitia i fauna ordovika severo-Zapadnogo Salaira. Moskva : Nauka, 1985.

G (690) Aki6t vyp. 637

GEOLOGY, STRATIGRAPHIC--ORDOVICIAN--PERIODICALS.

Ordovician news. Ordovician news. Sydney : The Subcommission, 1983333 or 2

GEOLOGY, STRATIGRAPHIC--PALEOZOIC.

Karasek, Richard Mark. Structural and stratigraphic analysis of the Paleozoic Murzuk and Ghadames basins, Western Libya. [Columbia, S.C.: University of South Carolina, Earth Sciences and Resources Institute, ig8l] G (232) oc2 no.I

GEOLOGY, STRATIGRAPHIC--PALEOZOIC--ADDRESSES, ESSAYS, LECTURES. Dokembrii i paleozoi severo-Vostoka SSSR. 'Magadan': [s.n.], 1974. $330(691)$ D 685 MP only

GEOLOGY, STRATIGRAPHIC--PENNSYLVANIAN.

Fonner, R. F. Geology along I-79, Harrison County, West Virginia. [Morgantown, W.V.] : West Virginia Geological and Economic Survey, 1981. (228) P962 no.18

GEOLOGY, STRATIGRAPHIC--PENNSYLVANIAN--MAPS .

Clark, Reino F. Stratigraphic sections, depositional environments, and metal content of the upper part of the Middle Pennsylvanian Minturn Formation, Northern Sangre De Cristo Range, Custer and Saguache Counties, Colorado. Reston, Va.: U.S. Geological Survey, 1985.

$M(271) 336$ Sa58c -- M(200) 4 vunjmf no.ín22-D - M(200) MF no.1622-D

GEOLOGY, STRATIGRAPHIC--PERMIAN

Kowalczyk, Gotthard. Das Rotiiegende zwischen Taunus und spessart. Wiesbaden : Hessisches Landesamt für Bodenforschung, 1983.

$(530.6) \mathrm{Ab} B d .84$ 
GEOLOGY, STRATIGRAPHIC--PLEISTOCENE.

Ashbaugh, Karen MCCort. Fossil molluscan faunas from four spring-related deposits in the northern Chihuahuan Desert, southern New Mexico and westernmost Texas. Socorro : New Mexico Bureau of Mines $\varepsilon$ Mineral Resources, 1986.

(272) qC no.200

Gerrard, A. J. Periglacial landforms of the Cox Tor - Staple Tors area of western Dartmoor. Birmingham, England : Dept. of Geography, University of Birmingham, 1983.

$\mathrm{S}(510)$ qW892 no.13

GEQLOGY, STRATIGRAPHIC--PRE-CAMBRIAN .

Evolîtesîa dokembrilskogo magmatizma : na primere Karelii.

Leningrad : Nauka, Leningradskoe otd-nie, 1985.

$170(570)$ Ev64

Garrison, James R. Geology of the Precambrian rocks of the Llano Uplift, central Texas : field trip notes. Austin, Tex. : Austin Geological Society, 1984 .

G(245) G938 no. 5

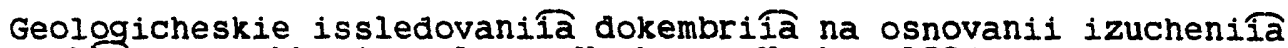
akEsessornykh mineralov. Moskva : Nauka, 1985. $320(570) \mathrm{G} 292$

Greiffo, Wania. Geochemie, Mineralogie und Petrologie de präkambrischen Eisenerze des Eisernen Vierecks, Minas Gerais, Brazilien. Clausthal : Technischen Universitat Clausthal, 1985. $320(410) \mathrm{G} 863 \mathrm{~g}$

Khabarov, E. M. Sravnitelhaia kharakteristika pozanedokembriiskikh rifogennykh formatsii : Iug Vostochnoi Sibiri, IUzhnyi Ural i Timan. Novosibirsk : Nauka, Sibirskoe otd-nie, 1985. G (690) AkI6t vyp.618

GEOLOGY, STRATIGRAPHIC--QUATERNARY .

Anundsen, Karl. Quaternary geological studies in Sunnhordland and NordRogaland, southwest Norway. 1980.

$352(581)$ qAn92q

Bittersohl, Jochen. Versickerung und Grundwasserneubildung in den quartären Deckschichten der Bayerischen Rhon. 1980. $490(530)$ B548v

Morrison, Roger Barron. Quaternary stratigraphy $\&$ archaeology of the Lake Lahonton area : a re-assessment : 1984 Annual meeting, Geological Society of America, Reno, Nevada ; supplementary guidebook for field trip 13. 2nd ed. Reno, NV : Desert Research Institute, 1984.

$209.1(275)$ M834q D

Quaternary environments : Eastern Canadian Arctic, Baffin Bay, and West Greenland. Boston : Allen \& Unwin, 1985.

$352(980)$ Q28

Symposium on Correlation of Quaternary Chronologies (1983 : Atkinson College). Correlation of Quaternary Chronologies. Norwich, Eng. : Geo Books, cl984. 352 sy68c 
GEOLOGY, STRATIGRAPHIC--QUATERNARY--CONGRESSES .

International Association for Quaternary Research. Congress (7th : 1965 : Denvee and Boulder, Colorado). Nauchnye itogi i materialy: VII [i.e. sedmoi] kongress mezhdunarodnoi assotsiatsii po izucheniî̀ chetvertichnogo perioda - INQUA (SShA, I965 g.). Moskva : Nauka, 1967. $352(200)$ In8n MP only

Quaternary evolution of the Great Lakes. St. John's, Nfld., Canada : Geological Association of Canada, Dept. of Earth Sciences, Memorial University of Newfoundland, 1985.

G (100) G29sp no.30

GEOLOGY, STRATIGRAPH IC--QUATERNARY--YEARBOOKS .

University of Cambridge. Sub-Department of Quaternary Research. Annual report. [Cambriage, Cambridgeshire] : The sub-Department.

$G(520)$ Un3qar

GEOLOGY, STRATIGRAPHIC--TERTIARY .

Benson, Richard N. Geological studies of cretaceous and tertiary section, test well JE32-04, Central Delaware. Newark, Delaware : University of Delaware, Delaware Geological Survey, 1985.

(224) B no.17

Stratigrafî́a i paleontologîia paleogena Gruzii. Tbilisi : MeEsnniereba, 1985 .

G (570) T44tn vyp.89

Ward, Lauck $W$. Stratigraphy and characteristic mollusks cf the Pamunkey Group (lower Tertiary) and the old Church Formation of the Chesapeake Group-Virginia Coastal Plain. Washington: U.S. G.P.O., 1985.

(200) qB no.1346 D MP

GEOLOGY, STRATIGRAPH IC--TERTIARY--CONGRESSES .

Mezhdunarodnyi kongress po Tikhookeanskomu neogenu (2nd : 1979 : Khabarovsk). Neogen tikhookeanskoi oblasti : Imaterialy II Mezhdunarodnogo Kongressa po tikhookeanskomu neogenu. Moskva : [s.n.], 1982.

351 (080) M578n MP only

GEOLOGY, STRUCTURAL .

Ali-zade A. A. Nauchnaîa oEsenka perspektiv neftegazonosnosti

Azerbaidzhana i. IUzhnogo Kaspiia i napravlenie poiskovo-razvedochnykh

rabot. Baku : ĖIm, 1985.

$467(572)$ A $152 \mathrm{n}$

Bakhturov, S. F. Bituminoznye karbonatno-slantSevye formaEsii VostochnoI Sibiri. Novosibirsk : Nauka, Sibirskoe otd-nie, 1985.

G(690) Akl6t vyp.617

Breer, Wolfgang. Der tektonische Bau der Lippe-Mulde im nördlichen Ruhrkarbon. 1975.

$210(530)$ B745t MP

Flückiger, Otto. Morphologische Untersuchungen am Napf. Bern : Büchler $\varepsilon$ Co. 1919

$210(535)$ F672m 
Kazimirov, A. D. Pokrovy vostoka Koriakskogo nagoria $i$ ikh strukturnoformaEsionnye gomologi. Moskva : Nauka, 1985.

$G(570)$ ACl22g2p vyp.391

Neíman, V. B. Teori住 i metodika paleotektonicheskogo analiza. Izd. 3-e, perer. $i$ dop. Moskva : Nedra, 1984.

210 N317t 1984

Pshenichnyl, G. N. Tekstury i struktury rud mestorozhdenil kolchedannoi formaEsii IUzhnogo Urala. Moskva : Nauka, 1984.

$410(570)$ P958t

Smirnov, A. M. Ocherki metallogenii Tikhookeanskogo dokembrîa. Moskva : Nauka, 1985.

$203(050)$ Sm480

GEOLOGY, STRUCTURAL--ATLASES.

Seismic expression of structural styles : a picture and work atlas. Tulsa, Okla., U.S.A. : American Association of Petroleum Geologists, 1983$G(200)$ fem3st no.15

GEOLOGY, STRUCTURAL--CHARTS, DIAGRAMS, ETC.

Quade, Horst. Die Lagenkugelprojektion in der Tektonik : das Schmidtsche Netz und Seine Anwendung. Clausthal-zellerfeld : E. Pilger, 1984.

$G(530)$ C574 no.20

GEOMORPHOLOGY--TEXAS--GUADALUPE MOUNTAINS.

MCKnight, Cleavy Louis. Descriptive geomorphology of the Guadalupe Mountains, south-central New Mexico and west Texas. Waco, Tex. : Baylor University, Department of Geology, [1986]

$G(245)$ qB35b no.43

GEOPHYSICAL WELL LOGGING--DATA PROCESSING.

Doveton, John H. Log analysis of subsurface geology : concepts and computer methods. New York : Wiley, 1986.

426 D 7521 D MP

GEOPHYSICS.

Peck, Lindamae. Review of methods for generating synthetic seismograms.

[Hanover, N.H. : U.S. Army Cold Regions Research \& Engineering Laboratory], 1985.

P(200) DS5r no.85-10

GEOPHYSICS--INTERNATIONAL COOPERATION--HANDBOOKS, MANUALS, ETC.

International Council of Scientific Unions. Panel on World Data Centres (Geophysical and Solar). Fourth consolidated guide to international data exchange through the Worla Data Centres. Washington [D.C.]: Secretariat of the ICSU Panel on World Data Centres, [1979]

295 In8f

GEOTHERMAL ENGINEERING--SOUTHWESTERN STATES.

Regional operations research program for development of geothermal energy in the southwest United States : final technical report, June 1977 to August 1978. Las Cruces : New Mexico Energy Institute, [1979]

$S(272)$ N4I8n no. 10 
GEOTHERMAL RESOURCES--IMPERIAL VALLEY, CALIF .

Layton, David $W$. An assessment of geothermal development in the Imperial Valley of California : environment, health, socioeconomics and environmental control technology : executive summary. Washington, D.C.: U.S. Dept. of Energy, Technology Assessments Division ; Springfield, VA. : Available from National Technical Information Service, [1980] $230(276)$ L $455 \mathrm{ae}$

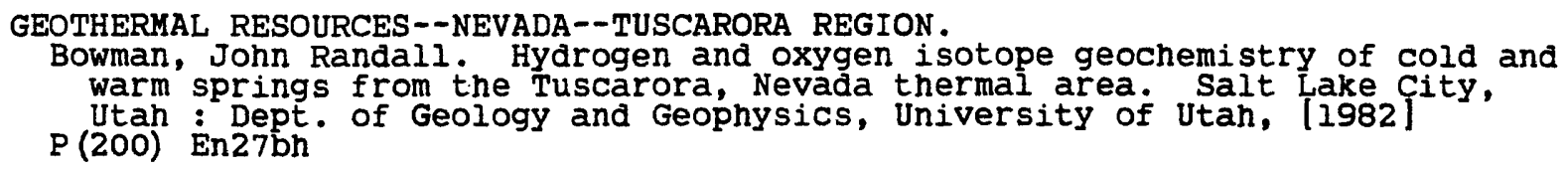

GEOTHERMAL RESOURCES--NEW YORK (STATE) .

New York State Geological Survey. Microseismic monitoring for evidence of geothermal heat in the Capital District of New York : final report, phases IIII. [AIbany, N.Y.] : New York State Energy Research and Development Authority, [1983]

$P(221)$ En27e no.83-6

GEOTHERMAL RESOURCES- UNITED STATES.

Site-specific analysis of geothermal development : vol. 1, summary report. Washington : U.S. G.P.O., [1978] $230(200)$ Si86

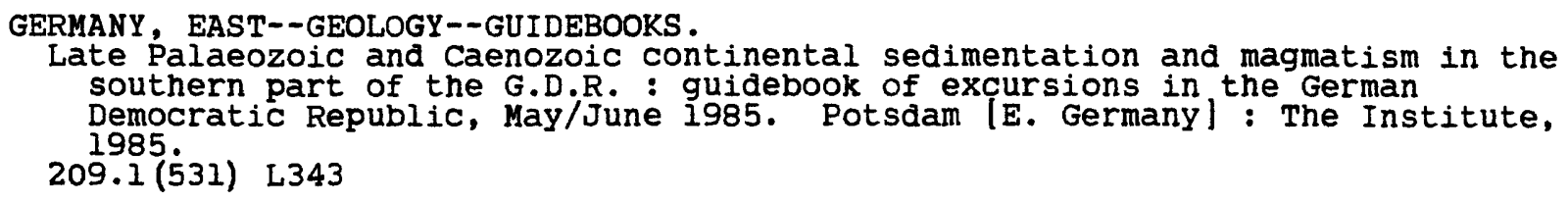

GLACIAL EPOCH--NORWAY.

Larsen, Eiliv. Weichsel stratigrafi og glasialgeologi pà Nordvestlandet. 1984.

250 (58i) qL328w

GLACIAL EPOCH--NORWAY--GUDBRANDSDAL.

Garnes, Kari. Studier av siste istids forløp og avsetninger $i$

gudbrandsdalen = Studies of the development and the glacial deposits of the last ice age in Gudbrandsdalen, South Norway. 1980. $250(581)$ qGi87s

GLACIAL EROSION--ALASKA.

Sloan, Charles E. Effect of glacier ablation on the snettisham Hyaroelectric Project, Long Lake and Crater Lake Basins, Alaska. Anchorage, Alaska: U.S. Geological Survey, 1986. (200) WRi no.85-4315 D MP

GLACIAL LANDFORMS-NORWAY .

Haldorsen, Sylvi. Genesis and composition of Norwegian tills: illustrated by studies from two areas in southeastern Norway. 1981. $518(581)$ qH132g

GLACIERS .

Holocene glaciers. Uppsala, Sweden : The Society, 1982.

$\mathrm{G}(583)$ qst84 v.18 
GLACIERS--NORWAY--JOSTEDALSBRE .

Seue, Christen de. Le névé de Justedal et ses glaciers. Christiania : H.J. Jensen, 1870 .

$250(581)$ qSe82n

GLACIERS--SOVIET CENTRAL ASIA--ADDRESSES, ESSAYS, LECTURES.

Gliatsiologi ia gornykh oblastei : snezhnyi pokrov, laviny i ledniki. Moskva : Moskovskoe otd-nie Gidrometeoizdata, 1984.

s (695) T17t vyp.105(186)

GLACIERS- - SOVIET UNION.

Materialy nablîudeni i na gornolednikovykh basseĭnakh mezhdunarodnogo

gidrologicheskogo desiatiletiia v Sovetskom Soiuze. Leningrad: Gidrometeoizdat, 1980-

$250(570)$ M418n MP only

GNEISS--SOVIET UNION--ADDRESSES, ESSAYS, LECTURES.

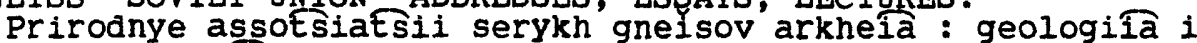

petrologiia. Leningrad : Nauka, Leningradskoe otd-nie, 1984.

$320(570)$ P938a D

GOLD ORES.

Senftle, Frank E. Synthesis of Au+b2।sS and Au,b2 isSib3 isusing Hib2।sS, short-chain and ring-structured sulfur as sulfur sources. [Reston, VA] : U.S. Geological Survey, 1986.

(200) R290 no.86-179 D MP

GOLD ORES--AUSTRALIA.

de Havelland, D. W. Gold $\&$ ghosts : a prospectors guide to metal detecting and history of the Australian goldfields. Victoria Park, Western

Australia : Hesperian Press, ci985.

431 D366g

GORGES--COLUMBIA RIVER, OR. AND WASH.

The Columbia gorge : a unique American treasure. Pullman, Wash. : College of Agriculture, Washington State University, 1984.

$552(280)$ C 723

GRAVITY STATIONS--NEVADA--ELKO COUNTY.

Saltus, R. W. Principal facts for 125 gravity stations in and around the Goshute Mountains-Toano Range, Elko County, Nevada. [Denver, CO]: U.S. Geological Survey, [1986]

(200) R290 no.86-153 D MP

GREAT BRITAIN--PHOTO MAPS.

Bullard, R. K. Britain from space : an atlas of Landsat images. London ; Philadelphia : Taylor E Francis, 1985.

$508(510)$ qB873b

GREAT SALT LAKE--WATER LEVEL.

United States. Bureau of Land Management. Draft environmental impact statement for the West Desert Pumping Project. Salt Lake City : The Bureau, [1986]

$585.3(273)$ Un 34 wd

GROUND CONTROL (MINING) .

Moebs, Noel N. Geotechnology in slate quarry operations. Pittsburgh, Pa. : U.S. Bureau of Mines, 1986.

$402(200)$ Un34ex no.9009 
GROUND CONTROL (MINING)--INSTRUMENTS.

Bauer, Eric R. Ground Control instrumentation : a manual for the mining industry. [Avondale, MD]: U.S. Dept. of the Interior, Bureau of Mines, 1985.

$402(200)$ Un34ic no. 9053

GROUND PENETRATING RADAR--COLD WEATHER OPERATION.

Arcone, Steven A. Model studies of surface noise interference in groundprobing radar. [Hanover, N.H. : U.S. Army Corps of Engineers, Cold Regions Research \& Engineering Laboratory, 1985] $P(200)$ DS5r no.85-19

GROUNDWATER FLOW--COMPUTER PROGRAMS.

Ghassemi, F. Finite element models for two-dimensional steady and transient groundwater flow-programs, case studies, and comparison with finite difference method. Manly Vale, N.S.W. Australia : The University of New South Wales, Water Research Laboratory, [1984]

$\mathrm{s}(820) \mathrm{N} 478 \mathrm{r}$ no.164

GROUNDWATER FLOW--TENNESSEE.

Tucci, Patrick. Ground-water flow in Melton Valley, Oak Ridge reservation, Roane County, Tennessee : preliminary model analysis. Nashville, Tenn. : U.S. Geological Survey, 1986. (200) WRi no.85-4221 D MP

GROUNDWATER TRACERS.

Ground-water tracers. Worthington, Ohio : National Water Well Association, 1985.

494 G9i8wt

GUYANA--GEOLOGY.

Barron, C. N. Notes on the stratigraphy of Guyana. [S.I. : s.n.. 1966?] $203(480)$ qB278n

HAZARDOUS SUBSTANCES--ENVIRONMENTAL ASPECTS.

Emerging technologies for treating hazardous wastes. [Amsterdam : Elsevier Science Pub., 1985]

817 J826 V.12 no.2

HELIOSPHERE--ADDRESSES, ESSAYS, LECTURES.

Collisionless shocks in the heliosphere : reviews of current research. Washington, D.C. : American Geophysical Union, 1985.

$\mathrm{s}(200)$ Am285ǵm no. 35

Collisionless shocks in the heliosphere : a tutorial review. Washington. D.C.: American Geophysical Union. 1985.

$\mathrm{s}(200)$ Am $285 \mathrm{gm}$ no. 34

HORNBLENDE--SCOTLAND--INVERNESS-SHIRE.

Rock, N. M. S. New types of hornblendic rocks and prehnite-veining in the

Moines west of the Great Glen, Inverness-shire. London : H.M.S.O., 1984.

(510) qR2 no.83/8

HUMIC ACID.

Choudhry, Ghulam Ghaus. Humic substances : structural, photophysical, photochemical, and free radical aspects and interactions with environmental chemicals. New York : Gordon and Breach Science Publishers, c1984. $875 \mathrm{c} 458 \mathrm{~h}$ 
HYDRAULIC ENGINEERING--DIRECTORIES.

International Association for Hydraulic Research. Register of members = Registre des membres. Delft, Netherlands : The Association.

056.778 In8r

HYDRAULICS.

Blank, Reinhard. Untersuchung des Schwarmverhaltens von grobstückigen Feststoffen beim vertikalen hydraulischen Transport in Rohrleitungen. 1981.

$778 \mathrm{~B} 612 \mathrm{u}$

HYDRAULICS--MATHEMATICAL MODELS.

Lai, Chintu. Computer simulation of two-dimensional unsteady flows in estuaries and embayments by the method of characteristics : basic theory and the formulation of the numerical method. [Reston, Va.] : U.S. Geological survey, [1977]

(200) WRi no.77-85 D MP

HYDRODYNAMICS--ADDRESSES, ESSAYS, LECTURES.

Dinamika i termika rek i vodokhranilishch. Moskva : Nauka, 1984.

$780(570)$ D612

HYDROGEOLOGY--CONGRESSES.

International Association of Hydrogeologists. Congress (17th: 1985 : Tucson, Ariz.) Hyarogeology of rocks of low permeability. [S.I.] : The Committee, 1985.

701 qIn $8 \mathrm{~m}$ v.17

HYDROLOGICAL STATIONS--NEW ZEALAND.

Christian, R. Index to hydrological recording sites in New Zealand, 1985. Wellington : Published for the National Water and Soil Conservation Authority by the Water and Soil Directorate, Ministry of Works and Development, c1985.

$P(890)$ qW292mp no.88

HYDROLOGY--COLORADO--DENVER REGION .

Norris, J. Michael. Summary of hydrologic information for the Denver coal region, Colorado: Lakewood, Colo.: U.S. Geological Survey, 1985.

(200) WRi no.84-4337 D MP

HYDROLOGY--COLORADO--PARACHUTE CREEK WATERSHED.

Galyean, Kenneth C. Hydrologic data from Naval Oil Shale Reserves, Parachute Creek basin, northwestern Colorado, water years 1982-83. Lakewood, Colo. : U.S. Geological Survey, 1985.

(200) R290 no.85-647

HYDROLOGY--FLORIDA--HIGHLANDS COUNTY--MAPS.

Adams, D. Briane. Hydrology of Lake Placid and adjacent area, Highlands County, Florida. 'Tallahassee, Fla.] : U.S. Geological survey, 1985. M (234) 78 H537a

Belles, Roger G. Hydrology of Lake June in winter, Highlands County, Southcentral Florida. [Tallahassee, Fla.] : U.S. Geological survey, 1985. M(234) 78 H537b

HYDROLOGY--FLORIDA--ORANGE COUNTY--MAPS.

Smoot, James L. Hydrology of Lake Butler, Orange County, Florida.

[Tailanassee, Fla.] : U.S. Geological survey, 1985.

M(234) 78 or2s 
HYDROLOGY--MISSOURI--ST. CHARLES COUNTY.

Kleeschulte, Michael $\mathrm{J}$. Compilation and preliminary interpretation of hydrologic data for the Weldon spring radioactive waste-disposal sites, st. Charles County, Missouri : a progress report. Rolla, Mo.: U.S. Geological Survey, 1986. (200) WRi no.85-4272 D MP

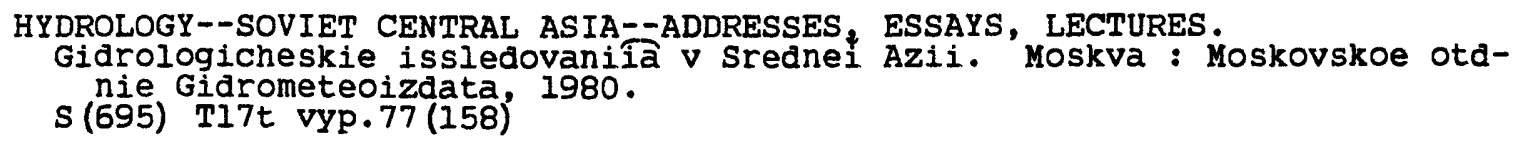

HYDROLOGY--SWITERLAND.

Tatigkeiten des Bundes auf dem Gebiet der operationellen Hydrologie. Bern : GHO, 1981 .

$780(535)$ qTi 88

ICE--CONGRESSES.

NATO Advanced Research Workshop on Ices in the Solar System (1984: Nice, France). Ices in the solar system. Dordrecht ; Boston : D. Reidei ; Hingham, MA, U.S.A. : Sold and distributed in the U.S.A. and Canada by Kluwer Academic, 1985.

$737 \times 214 i$

ICE ON RIVERS, LAKES, ETC.--GREENLAND--ANGIUSSAQ LAKE REGION.

Taylor, Lawrence Dow. Ice structures, Angiussaq Lake, northwest Greenland. Bedford, Mass, Air Force Cambridge Research Center, Geophysics Research Directorate, [1959]. $256(980)$ T215i

ICE ON RIVERS, LAKES, ETC.--SIBERIA, NORTHEASTERN

Dementév, V. A. Iskusstvennye sooruzhenila na vodotokakh $s$ naledíami. Leningrad : Stroìzdat, Leningradskoe otd-nie, 1983.

$256.2(690.3)$ D $394 i$

ICE ON RIVERS, LAKES, ETC.--SOVIET UNION--ADDRESSES, ESSAYS, LECTURES.

Issledovani ia, raschety i prognozy ledovykh iavlenil na rekakh, kanalakh $i$ vodokhranilishchakh. Leningrad : Gidrometeoizdat, 1982.

$780(570)$ R92t vyp.287

INDIA--CLIMATE--TABLES.

Osnovnye klimaticheskie dannye po stranam IUzhnoí Azii i po Mongolskkoi Narodnoi Respublike : Chast'2 : Indîia, Shri Lanka, MNR. Moskva : Moskovskoe otd-nie Gidrometeoizdata, 1982.

$512(600)$ q0s5 pt.2

INFORMATION STORAGE AND RETRIEVAL SYSTEMS--NAMES, GEOGRAPHICAL.

Geographic Names Information System : data users guide 6 . Reston, VA : U.S. Geological survey, 1985.

R (200) G293

INTERNATIONAL GEOPHYSICAL YEAR, 1957-1958.

International Geophysical Year, 1957-1958. Roster of the US-IGY Program : being essentially all names in the "Report on the US Program for the International Geophysical Year, 1957-1958" (IGY General Report No.21, National Academy of Sciences, November 1965 and IGY Antarctic Scientific Personnel). Washington, D.C. : Geophysics Research Board, National Academy of Sciences], [ig83]

295 In8r 
INTRUSIONS (GEOLOGY) --UTAH--SAN RAFAEL MOUNTAINS REGION.

Gartner, A. E. Geometry, emplacement history, petrography and chemistry of a basaltic intrusive complex, san Rafael and Capitol Reef Areas, Utan. [Menlo Park, Calif.] : U.S. Geological Survey, [1986] (200) R290 no.86-8I D MP

IOWA--GEOLOGY--IOWA CITY--GUIDEBOOKS.

Geology of the University of Iowa campus area, Iowa City : a walking tour along the Iowa River. [Iowa City] : Iowa Geological Survey, 1984.

(262) Io6 no.7

IRELAND--GEOLOGY--DONEGAL COUNTY .

North East Co. Donegal and North West Co. Londonderry : 1984 Field Meeting, 28 th-30th September. [S.I.]: Irish Association for Quaternary studies, [1984]

G(516) F455 no.7

IRON ORES--BRAZIL--MINAS GERAIS.

Guba, Ingeborg. Tektonik, Texturen und Mineralogie der präkambrischen Eisenerze und Nebengesteinsserien der Lagerstatte Morro Agudo im NE des Quadrilátero Ferrifero/Minas Gerais, Brasilien. 1982 . $433(410)$ G933t

ISOSTASY.

Fjeldskaar, Willy. Late-glacial movements of sea level and crust in Fennoscandia. 1981 .

297 (580) qF5881

ISOTOPE GEOLOGY --ADDRESSES, ESSAYS, LECTURES.

Izotopnaia geologiia. Moskva : Nedra, 1984.

203.7 L497R

JUPITER (PLANET) --PHOTO MAPS.

Geological Survey (U.S.). High resolution controlled photomosaics of Io. Reston, va.: The Survey, 1983.

M(030.1) 5.1 i 19839 - M(200) 2 vun3m no.1494 -- M(200) I no.1494

Geological Survey (U.S.). Shaded relief and surface markings of the Galileo Regio quadrangle of Ganymede. Reston, Va. : The Survey, 1984.

$M(030.3) 5.1$ G133g -- M(200) 2 vUn3m no.1649 -- M(200) I no.1649

Geological Survey (U.S.) . Shaded relief and surface markings of the Lerna region of IO. Reston, Va.: The Survey, 1984 .

$M(030.1) 5.1$ L562g -- M(200) vUn3m no.1549 -- M(200) I no.1549

Geological Survey (U.S.). Shaded relief and surface markings of the Uruk Sulcus quadrangle of Ganymede. Reston, Va. : The Survey, 1984.

$M(030.3) 5.1$ Ur8g - M (200) 2 VUn3m no.1536 -- M(200) I no.1536

Geological Survey (U.S.). Shaded relief and surface markings of the Misharu quadrangle of Ganymede. Reston, Va. : The Survey, 1984.

$M(030.3) 5.1$ M687g -- M(200) 2 vUn3m no.1650 -- M(200) I no.1650

Geological survey (U.S.). Shaded relief and surface markings of the Tiamat Sulcus quadrangle of Ganymede. Reston, Va. : The Survey, 1984.

$M(030.3) 5.1$ T432g -- M (200) 2 vUn $3 m$ no.1548 - M (200) I no.i 548 
Geological Survey (U.S.) . Shaded relief and surface markings of the Ruwa Patera Region of Io. Reston, Va.: The Survey, 1984.

$M(030.1) 5.1$ R942g -- M(200) 2 vÜn 3m no.1491 - M(200) I no. 1491

KAOLIN-ENGLAND.

Highley, D. E. China clay. London : H.M.S.O., 1984.

(510) qud no.26

KARST.

Jennings, J. N. Karst geomorphology. 2nd ed., rev. New York, NY : Basil Blackwell, 1985 .

$547 \mathrm{~J} 445 \mathrm{k}$

LAKES--SOUTH AMERICA.

Panero, Robert B. A South American "Great Lakes" system : preliminary report. Croton-on-Hudson, N.Y.: Hudson Institute, [1967]

$552(400)$ P192s

LAKES--SOVIET UNION--WHITE LAKE.

Gusakov, Boris Lavrentévich. Beloe ozero : proshloe, nastoîshchee i budushchee. Leningrad : Gidrometeoizdat, 1983.

$554(570)$ G972b

LAND USE--ENVIRONMENTAL ASPECTS--CALIFORNIA.

United states. Bureau of Land Management. California desert conservation area : final environmental impact statement and proposed plan, appendix. Reprint 1981. [Riverside] : The Bureau, [1980]

$585.3(276)$ Cl33fea

LAND USE--GEORGIA--DOUGLAS COUNTY.

Spann, G. William. Study of USGS/NASA land-use classification system : interim technical report. Atlanta: Engineering Experiment station, Georgia Institute of Technology, [1974]

$585.5(233)$ Sp24s

LANDFORMS - MONTANA--MAPS .

Weidman, Robert M. Lineament map of Western Montana. [Butte, Mont.] : Montana Bureau of Mines and Geology, 1973 [i.e., 1982]

M (281) 54 W525w

LANDSCAPE--ENGLAND.

The English landscape : past, present, and future. Oxford [Oxfordshire] ; New York : Oxford University Press, 1985.

$903(520) \operatorname{En} 34$

LANDSLIDES--WASHINGTON (STATE)--CASTLE CREEK, SOUTH FORK.

The Effects of ground water, slope stability, and seismic hazard on the stability of the South Fork Castle Creek blockage in the Mount St. Helens area, Washington. Washington : U.S. G.P.O., 1985. (200) qB no.1345 D MP F

LIBRARY INFORMATION NETWORKS--UNITED STATES--CONGRESSES.

Network Advisory Committee. Meeting (1984 Nov. 14-16: Library of Congress). The information economy in the U.S. : its effect on libraries and library networks : proceedings of the Library of Congress Network Advisory Committee Meeting, November 14-16, 1984. Washington, D.C. : Network Development and MARC Standards Office, Library of Congress, 1985.

$040(200)$ N388 no. 10 
LIMNOLOGY--ALASKA--LAKE PETERS.

Hobbie, John E. Limnological studies on Lake Peters and Schrader, Alaska. Bedford, Mass. : The Center, 1960.

$554(286)$ H6521

LIMNOLOGY--WASHINGTON (STATE) .

Baseline study of reflection lakes, Mount Rainer National Park. Pullman, WA : State of Washington Water Research Center, [1985]

$S(284)$ Un64r no.66

LIMNOLOGY--WISCONSIN--MENDOTA, LAKE.

Brock, Thomas D. A eutrophic lake : Lake Mendota, Wisconsin. New York : Springer-Verlag, 1985.

919 EC73s v. 55

LOESS.

INQUA Commission on Loess and Paleopedology. Symposium. (11th : 1982 : Moscow). Lithology and stratigraphy of loess and paleosols : proceedings of the symposium organized by INQUA Commission on Loess and Paleopedology, XIth INQUA Congress, Moscow. Budapest [Hungary]: Geographical Research Institute, Hungarian Academy of Sciences, 1984.

518 In81s

LOESS--NEW ZEALAND--WAIRARAPA VALLEY--ANALYSIS.

Palmer, A. S. Dry bulk density, natural water content, and tip penetration date for four Wairarapa loess cores. Lower Hutt, N.z.: Dept. of Scientific and Industrial Research, 1984.

$P(890)$ qSo3n no.68

LONG VALLEY DAM (MONO COUNTY, CALIF.)--EARTHOUAKE EFFECTS.

Lai, S. S. Dynamic response of Long Valley Dam in the Mammoth Lake earthquake series of May 25-27, 1980. Berkeley, Calif. : College of Engineering, University of California ; Springfield, Va. : for sale by the $N$. T.I.S., 1985.

$240(276)$ 'Cl3ir no.85-12

LOUISIANA--GEOLOGY--MAPS.

Louisiana Geological Survey. Geologic map of Louisiana, 1984. Baton Rouge, LA. : The Survey, 1984.

M (237) 219841 D MP

MAGNETIC MATERIALS--CONGRESSES--ABSTRACTS .

European Conference on Soft Magnetic Materials (5th : 1981 : Grenoble, France). Soft magnetic materials 5 : Grenoble $(F), 22-25$ September. [Petit-Lancy, Switzerland]: European Physical Society; c1981.

$S(500)$ Eu745 v.5K

MAMMALS, FOSSIL.

Storer, John E. Mammals of the Swift Current Creek local fauna (Eocene: Uintan), Saskatchewan. Regina: Saskatchewan Culture and Recreation Museum of Natural History, 1984.

$602(165)$ N218 no.7

MANGAZEIA, SIBERIA--ANTIQUITIES.

Belov, Miknail Ivanovich. Mangazeîa : Mangazeľskil morskol khod, Chast 1. Leningrad : Gidrometeoizdat, 1980-

$590(690.2)$ B4l8m D only 
MARINE ECOLOGY--PACIFIC OCEAN.

Parmenter, Tish. The Oregon oceanbook : an introduction to the Pacific

Ocean off oregon including its physical setting and living marine resources. Salem, or.: : Dept. of Land Conservation and Development, 1985. 530.6 fP2 420

MARINE GEOPHYSICS--NORWEGIAN-GREENLAND SEA.

Eldholm, Olav. The sediment distribution and main structural elements of the Norwegian-Greenland Sea and surrounding areas based on marine geophysical data. 1976. $213(055)$ qE124s

MARINE GEOPHYSICS--SEAWARTE SEAMOUNTS.

Verhoef, Jacob. A geophysical study of the Atlantis-Meteor seamount complex $=$ Een geofysische studie van het Atlantis-Meteor seamount complex. Utrecht [Netherlands] : Drukkerij Elinkwijk BV, 1984. G(591) qut3g no.38

MARINE MINERAL RESOURCES--BALTIC SEA--CONGRESSES. Eksploatacja złoz minerałów ciezkich poluaniowego Bałtyku : Karpacz, 2426 kwietnia 1981. Wroclaw : Wya. politechniki Wroclawskiej, 1984. $537(057)$ Ek 78

MARINE POLLUTION--ADDRESSES ESSAYS, LECTURES. Ekologicheskie posledstviia zagriazneniia okeana. Leningrad : Giarometeoizdat, 1985. 537.5 Ek 74

MARINE POLLUTION--UNITED STATES--PERIODICALS. United States. National Ocean Service. Report to the Congress on ocean pollution, monitoring and research. Washington, D.C.: The Service, 1983$P(200)$ NO23r

MARINE RESOURCES--MEXICO, GULF OF--MAPS.

Gulf of Mexico coastal and ocean zones strategic assessment : data atlas. [Rockville, Ma.] : National Oceanic and Atmospheric Administration, National Ocean Service ; Washington, D.C. : For sale by the Supt. of Docs., U.S. G.P. $0 ., 1985$.

$R$ P $(200)$ f́f

MARINE SEDIMENTS--NORWAY--BARENTS SEA.

Sundvor, Eirik. Seismiske undersøkelser av den norske kontinentalsokkel : Lofoten--Bjørnøya, 68:-75Nं; Bergen [Norway] : Universitetet $i$ Bergen, Jordskjelvstasjonen, [1971]. $\mathrm{s}(581)$ qB45tr $\mathrm{nr} .5$

MARINE SEDIMENTS--PACIFIC OCEAN.

Ignatova, Valentina Fedorovna. Osadkonakoplenie na sovremennykh i drevnikh shelfakh $v$ zone perekhoda ot Evraziiskogo kontinenta $k$ Tikhomu okeanu. Moskva : Nauka, 1983. 536 Ig60

MARITIME LAW--UNITED STATES--CONGRESSES.

The United States without the Law of the Sea Treaty : opportunities and costs : proceedings from the seventh annual conference held June 12-15, 1983, Center for Ocean Management Studies, University of Rhode Island. Wakefield, R.I. : Times Press, 1983. $537.2(200)$ Un3 
MARS (PLANET) --ARABIA QUADRANGLE--PHOTO MAPS.

Geological Survey (U.S.). Shaded relief map of the Arabia quadrangle of Mars. Rev. Mar. 1984. Reston, Va. : The Survey, 1984

$M(031) 5.1$ Ari2g -. M(200) 2 vUn3m no.i651 - M (200) I no.i65 I

MARS (PLANET) --MAJA VALLES REGION--PHOTO MAPS.

Geological survey (U.S.). Controlled photomosaic of part of the Maja

valies region of Mars. Reston Va. : The Survey, 1985.

M (031) 5.1 M289g8 -- M(200) 2 vUn3m no.i678 - M M(200) I no.1678

Geological Survey (U.S.). Controlled photomosaic of part of the Maja Valles region of Mars. Reston, va. : The survey, 1985.

$M(031) 5.1$ M288g5 -- M(200) 2 vUn3m no.1675 - M (200) I no.1675

Geological survey (U.S.). Controlled photomosaic of part of the Maja Valles region of Mars. Reston, va. : The survey, 1985.

$M(031) 5.1$ M8897 - M (200) 2 vUn 3m no.1677 -- M(200) I no.1677

Geological Survey (U.S.). Controlled photomosaic of part of the Maja Valles region of Mars. Reston, Va. : The survey, 1985.

$M(031) 5.1$ M288g9 -- M(200) 2 vUn3m no.1719 -. M(200) I no.1719

MARS (PLANET) --MANGALA VALLES REGION--PHOTO MAPS.

Geological survey (U.S.). Controlled photomosaic of part of the Mangala

Valles region of Mars. Reston, Va. : The Survey, 1985.

M (031) 5.1 M314g6 - M (200) 2 vUn3m no.1696 -- M(200) I no.1696

Geological Survey (U.S.). Controlled photomosaic of part of the Mangala valies region of Mars. Reston, Va. : The Survey, 1985.

$M(031) 5.1$ M314g2 - M (200) 2 vUn3m no.1652 - M(200) I no.1652

MARS (PLANET) --PHOTO MAPS.

Geological Survey (U.S.). Viking Lander 2 rectified photomosaic : evening scene - camera 2. Reston, Va. : The Survey, 1984.

$M(031) 5.11984 \mathrm{e} 2 \ldots \mathrm{M}(200) 2$ vUn3m no.1518 -- M (200) I no.1518

Geological Survey (U.S.). Viking Lander 2 rectified photomosaic : morning scene - camera 2. Reston, va. : The Survey, 1984.

$M(031) 5.11984 \mathrm{~m} 2$ - M (200) 2 vUn3m no.1516 -- M(200) I no.1516

Geological Survey (U.S.) Viking Lander 2 rectified photomosaic : evening scene - camera 1. Reston, Va. : The Survey, 1984.

$M(031) 5.11984 \mathrm{el}=\mathrm{M}(200) 2$ vUn3m no.1517 -- M(200) I no.1517

MARYLAND--GEOLOGY--BRISTOL QUADRANGLE--MAPS .

Glaser, John D. Geologic map of the Bristol quadrangle, Prince Georges, Anne Arundel, and Calvert Counties, Maryland. [Baltimore] : Maryland Geological Survey, 1984.

$M(225) 2$ B776g

MARYLAND--GEOLOGY--CHARLES COUNTY--MAPS .

Maryland Geological Survey. Map of Charles County showing the geological formations. [Baltimore] : Maryland Geological Survey, 1939.

$M(225) 2$ C382m 1939

MARYLAND--GEOLOGY--MAPS .

Cleaves, Emery T. Geologic map of Maryland. [Baltimore] : Maryland Geological Survey, 1968 .

$M(225) 21968 \mathrm{C}$ 
MARYLAND--GEOLOGY--MYERSVILLE QUADRANGLE--MAPS.

Fauth, John L. Geologic map of the Myersvilie quadrangle, Maryland. [Baltimore] : Maryland Geological survey, 1981.

M (225) 2 M9g2f

MARYLAND--GEOLOGY--PORT TOBACCO QUADRANGLE--MAPS .

Glaser, John $D$. Geologic map of the Port Tobacco quadrangle, prince Georges and Charles Counties, Maryland. [Baltimore]: Maryland Geological Survey, 1984.

M (225) 2 P832g

MARYLAND--GEOLOGY--SOMERSET COUNTY--MAPS.

Owens, James Patrick. Geologic map of Somerset County. [Baltimore?] : Maryland Geological survey, 1984 .

M (225) 2 So540

MARYLAND--MINERAL RESOURCES--BALTIMORE COUNTY--MAPS.

Kuff, Karen R. Mined land inventory map of Baltimore County $\varepsilon$ Baltimore City: Baltimore : Maryland Geological Survey, 1975. $M(225)$ \& B2l7k

MARYLAND--MINERAL RESOURCES--CARROLL COUNTY-MAPS .

Kuff, Karen R. Mineral resources and mined land inventory of Carroll County, Maryland. [Baltimore]: Maryland Geological Survey, 1982. M (225) 4 C $236 k$

MARYLAND--MINERAL RESOURCES--PRINCE GEORGE'S COUNTY--MAPS.

Kuff, Karen R. Mineral resources and mined land inventory, Prince George's County, Maryland. Baltimore : Maryland Geological Survey, 1980. $\mathrm{M}(225) 4 \mathrm{pg} 6 \mathrm{k}$

MASSACHUSETTS--GEOLOGY--MAPS.

Bedrock geologic map of Massachusetts. [Reston, Va.] : The Survey, 1983. $M(214) 21983 z$

MELANGES (PETROLOGY) .

Drake, Avery Ala. Tectonic implications of the Indian Run formation, a newly recognized sedimentary melange in the northern Virginia piedmont. Washington: U.S. G.P.O., 1985. (200) qB no.1324 D MP F

METEOROLOGY--ADDRESSES, ESSAYS, LECTURES.

International Union of Geodesy and Geophysics. General Assembly (18th: $1983:$ Hamburg, West Germany). Soobshchenie o nauchnykh rabotakn po meteorologii i fizike atmosfery, 1979-1982: predstaviiâetsiâ v Mezhdunarodnuiu assotsiatsiiu meteorologii i fiziki atmosfery k XVIII Generalhoi assamblee Mezhdunarodnogo geodezicheskogo i geofizicheskogo soiuza. Moskva : [s.n.], 1983.

510 In8s MP only

METEOROLOGY--BALTIMORE--STATISTICS-PERIODICALS.

Local climatological data. Baltimore, Maryland : Annual summary with comparative data. Local climatological data. Baltimore, Maryland : annual summary with comparative data. Ashevilie, N.C. : National Oceanic and Atmospheric Administration, National Environmental Satellite, Data and Information Service, National Climatic Data Center.

$P(200)$ NO24lbas 
METEOROLOGY --BOSTON--STATISTICS--PERIODICALS.

Local climatological data. Boston, Massachussets : Annual summary with comparative data. Local Climatological data. Boston, Massachussets : annual summary with comparative data. Asheville, N.C. : National Oceanic and Atmospheric Administration, National Environmental Satellite, Data and Information Service, National Climatic Data Center.

$P(200)$ NO241boa

METEOROLOGY --GEORGIA--ATLANTA--STATISTICS--PERIODICALS .

Local climatological data. Atlanta, Georgia : annual summary with comparative data. Local climatological data. Atlanta, Georgia :annual summary with comparative data. Asheville, N.C. : National Oceanic and Atmospheric Administration, National Environmental Satellite, Data and Information Service, National Climatic Data Center.

$P(200)$ NO2́laa

METEOROLOGY --PHILADELPHIA--STATISTICS--PERIODICALS .

Local climatological data. Philadelphia, Pennsylvania : annual summary with comparative data. Local climatological data. Philadelphia, Pennsylvania : annual summary with comparative data. Asheville, N.C. : Nátional Oceanic and Atmospheric Administration, National Environmental Satellite, Data and Information Service, National Climatic Data Center.

$P(200)$ No241pa

METEOROLOGY --WASHINGTON METROPOLITAN AREA--STATISTICS--PERIODICALS

Local Climatological data. Washington, D.C., Dulies International Airport : annual summary with comparative data. Local climatological data.

Washington, D.C., Dulles International Airport : annual summary with comparative data: Asheville, N.C. : National Oceanic and Atmospheric Administration, National Environmental Satellite, Data and Information Service, National Climatic Data Center.

$P(200)$ No24lwda

Local climatological data. Washington, D.C., National Airport : annual summary with comparative data. Local climatological data. Washington, D.C., National Airport : annual summary with comparative data. Asheville, N.C. : National Oceanic and Atmospheric Administration, National Environmental Satellite, Data and Information Service, National Climatic Data Center.

$P(200)$ No24iwna

MIDDLE ATMOSPHERE.

Shimazaki, Tatsuo. Minor constituents in the middle atmosphere. Tokyo, Japan : Terra Scientific Pub. Co. ; Dorarecht ; Boston : D. Reidel, ci985. $\mathrm{S}(620) \mathrm{D} 493 \mathrm{~V} .6$

MIHARA, MOUNT, JAPAN--ERUPTION, 1954.

The Eruption of Mihara-yama, D-shima from Dec. I to Dec. 24, 1954. [Tokyo, Japan : U.S. Geological Survey, 1954]

$209(900)$ qun33pr [no.487]

MILIOLIDAE, FOSSIL.

Temirbekova, $U$, T. Triasovye i Turskie miliolidy Severnogo Kavkaza. Moskva : Nauka, 1985.

$617(570)$ T2 $42 t$

MINE WATER--CONGRESSES.

International Congress of Mine Waters and Underground Works (2nd : 1985 : Granada, Spain). Mine water : proceedings of the Second International Congress. [S.1.] : International Mine Water Association, 1985. 425 W893p 1985 
MINERAL RESOURCES.

Skinner, Brian j. Earth resources. 3rd ed. Englewood Cliffs, N.J.: Prentice-Hall, cl986.

403 Sk34e 1986

MINERALOGISTS.

Muller, G. Das Berufsfeld des Industrie-Mineralogen. Stuttgart : E. Schweizerbartsche Verlagsbuchnandlung (Nagele u. Obermiller), 1985. 409 M913b

MINERALOGY .

Bluchel, Kurt. Zauber der Mineralien : Kristalle, Gold und Edelsteine. Zurich : Ringier, Cl981. 104 qB624z

MINERALOGY, DETERMINATIVE.

Metody issledovaniia prirodnykn organicheskikh veshchestv. Novosibirsk :

Nauka, Sibirskoe ota-nie, 1985.

G(690) Ákl6t vyp.608

MINES AND MINING--UTAH--WASHINGTON COUNTY .

Bernstein, Lawrence R. Geology and mineralogy of the Apex Germanium-

Gallium Mine, Washington County, Utah. Washington : U.S. G.P.O.;

Alexandria, va : For sale by the Distribution Branch, Text Products section, U.S. Geological Survey, 1986.

(200) E no.1577

MOLLUSCS, FOSSIL--ITALY--CATALOGS AND COLLECTIONS.

Catalogo dei tipi e degli esemplari figurati della collezione Bellardi e Sacco. Torino [Italy] : Museo Regionale di Scienze Naturali, 1981-1984. 654 M972C

MOLLUSKS, FOSSIL--SOVIET UNION--CONGRESSES

Vsesoîuznoe soveshchanie po izucheniîu mollî̀skov (5th: 1975 : Leningrad) .Molliuski : ikh sistema, evoliutsilia i rol'v prirode, avtoreferaty dokladov, sbornik piatyi. Leningrad : Nauka, Leningradskoe otd-nie; 1975.

$654(570)$ V968m MP only

MONTANA--GEOLOGY--DILLON QUADRANGLE--MAPS.

Alt, David D. [Preliminary geologic map of the Dillon 1 tpo isx 2tpo tsquadrangle, Montana] [Butte, Mont.] : Montana Bureau of Mines and Geology, [1978, i.e., 1980]

M (281) 2 D587a

MONTANA--GEOLOGY--GLENDIVE QUADRANGLE--MAPS.

Bermel, Wesley M. Montana geologic atlas : Glendive geology sheet.

[Butte, Mont.] : Montana Bureau of Mines and Geology, 1978 [i.e., 1980].

$M(28 I) 2$ G485b

NAMES, GEOGRAPHICAL--ANGOLA.

Thompson, Patricia K. Gazetteer of Angola : names approved by the United States Board on Geographic Names. 2nd ed., Feb. 1986. Washington, D.C. : Defense Mapping Agency, [1986]

R 506 Un28g Angola 1986 
NATURAL HISTORY--ANDES.

Morrison, Tony. The Andes. Amsterdam [Netherlands] : Time-Life Books, c1976.

$903(400) \mathrm{M} 834 \mathrm{a}$

NATURAL HISTORY--CALIFORNIA--ANTIQUITIES.

Moratto, Michael J. Final report of the New Melones archeological project, California : natural history. Salinas, CA : Coyote Press, 1982. $903(276)$ M797f MP only

NATURAL HISTORY--GERMANY, EAST--COLLECTED WORKS .

Abhandlungen und Berichte des Naturkundlichen Museums "Mauritianum,"

Altenburg. Abhandlungen und Berichte des Naturkundlichen Museums "

Mauritianum," Altenburg. Altenburg [Germany] : Das Museum, 1958$S(530)$ Ab46b

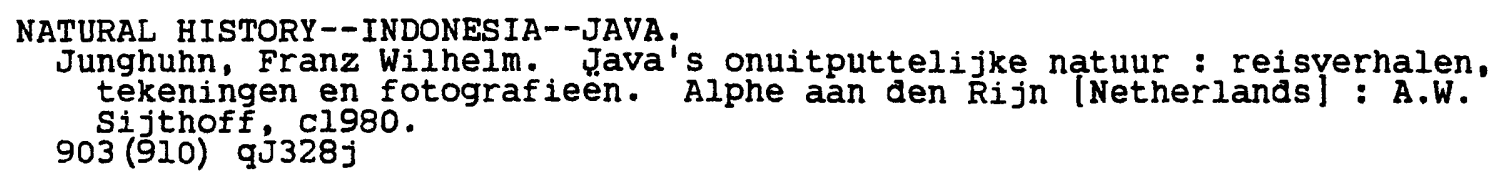

NATURAL HISTORY--JAPAN--AKIYOSHI PLATEAU--PERIODICALS .

Akiyoshidai Kagaku Hakubutsukan hokoku. Akiyoshidai Kagaku Hakubutsukan

hokoku = Bulletin of the Akiyoshi-dai Museum of Natural History.

Yamaguchi-ken Mine-gun Shuho-cho : Dò Hakubutsukan.

A (620) Ak53

NATURE CONSERVATION--UNITED STATES.

Fisher, Ronald M. Our threatened inheritance : natural treasures of the United States. Washington, D.C. : The Society, cl984.

$585.7(200)$ F5370

NEAR EAST--CLIMATE--TABLES.

Osnovnye klimaticheskie dannye po stranam Blizhnego i Srednego Vostoka $i$ IUzhnoi Azii (1966 - $1975 \mathrm{gg}$.) : Chast'1. Moskva : Moskovskoe otdnie Gidrometeoizdata, 1981. $512(600)$ qos $5 \mathrm{pt.1}$

NEVADA--MINERAL RESOURCES--LINCOLN COUNTY .

Chatman, Mark L. Mineral resources of a part of the Mount Grafton

Wilderness Study Area (NV-040-169), Lincoln and White Pine Counties, Nevada. Denver, Colo. : Intermountain Field Operations Center, U.S. Dept. of the Interior, Bureau of Mines, 1986.

402 (200) Un34msi no.29-86

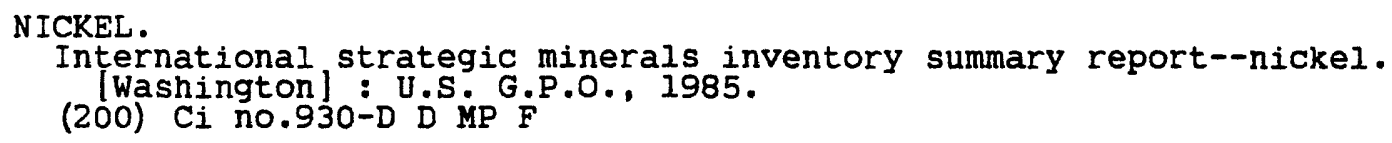

NICKEL ORES--WESTERN AUSTRALIA.

Marston, R. J. Nickel mineralization in Western Australia. Perth : Geological Survey of Western Australia, 1984.

$402(860)$ W52mb no.14 
NORTH AMERICA--GEOLOGY--PERIODICALS.

The Decade of Noth American geology, DNAG. Decade of North American

Geology, DNAG. Boulder, Colo.: The Society, 1986-

$042.2(200) \quad D 355$

OCEAN BOTTOM--ADDRESSES, ESSAYS, LECTURES .

Geologo-geofizicheskie issledovaniia dna okeanov. Moskva : VINITI, 1985. 210 G283 no.8

OCEANOGRAPHIC INSTRUMENTS--CONGRESSES.

Miernictwo oceanograficzne. Wroclaw : Zaklad Narodowy im. Ossolińskich,

$\mathrm{s}(578)$ St95 $\mathrm{nr} .42$

OCEANOGRAPHY

Zalogin, B. S. Okean cheloveku. Moskva : Mysl: 1983.
530 Z140

OCEANOGRAPHY AND STATE--UNITED STATES.

United States. National Advisory Committee on Oceans and Atmosphere. Task Group on Services to Ocean Operations.Ocean services for the nation : national ocean goals and objectives for the $1980^{\prime} \mathrm{s}$. Washington, D.C. : The Committee : [For sale by the Supt. of Docs., U.S. G.P.O., I i98i. 530 Un3osf $D$

OCEANOGRAPHY--ARABIAN SEA--CONGRESSES

Marine geology and oceanography of Arabian Sea and coastal Pakistan. New York ; London : Van Nostrand Reinhold, cl984.

$203(071)$ M838

OCEANOGRAPHY--ARCTIC REGIONS.

The Nordic seas. New York : Springer-Verlag, cl986.

$530.8 \times 758$

OCEANOGRAPHY--ATLANTIC COAST (U.S.)

Oceanography of the southeastern U.S. continental shelf. Washington, D.C. : American Geophysical Union, 1985.

$s(200)$ C632e v.2

OCEANOGRAPHY --BAFFIN BAY.

Fissel, D. B. The physical oceanography of western Baffin Bay and Lancaster Sound.Rev. ed. Ottawa : Northern Affairs Program, Indian and Northern Affairs Canada, [1981]

$P(100)$ N82e no.25

OCEANOGRAPHY--CHINA--DIRECTORIES.

$A$ brief introduction to the Chinese institutions of ocean science and technology. Beijing : China Ocean Press, 1984.

$057.530(610)$ B765

OCEANOGRAPHY --PERIODICALS.

Chinese journal of oceanology and limnology. Chinese journal of oceanology and limnology = Chung-kuo hai yang hu chao hsueh pao. Beijing, China : Science Press, 1982-

$\mathrm{S}(610) \quad \mathrm{C} 438$ 
OIL INDUSTRIES--FIRE AND FIRE PREVENTION.

Investigation of August 1984 fire lease OCS-G 2254, East Cameron Block 322 , Gulf of Mexico, off the Louisiana coast. [Reston, Va.] : U.S. Dept. of the Interior, Minerals Management Service, [1985] $402(200)$ M6620 no.85-0099

OIL-SHALE INDUSTRY--UNITED STATES--PERIODICALS

United States. Oil Shale Office. Report on the prototype oil shale leasing program. Grand Junction, Colo. : The Office, 1982402 (200) H662por

OIL WELL BLOWOUTS--MEXICO, GULF OF.

United States. Minerals Management Service. Investigation of May 1984 explosion and fire, lease OCS-G 3280, West Cameron Block 405, Gulf of Mexico, off the Louisiana Coast. [S.1.]: The Service, [1985] $402(200)$ M6620 no.85-0054

OIL WELL DRILLING--CONGRESSES.

Deep Drilling and Production Symposium (1986 : Amarillo, Tex.) . Proceedings : 1986 Deep Driliing and Production Symposium : April 6-8, 1986, Amarillo, Texas. [Dalias, Tex.] : Society of Petroleum Engineers, c1986. $467.1(200)$ D832p 1986

OIL WELL DRILLING--ENVIRONMENTAL ASPECTS--NORTHWEST TERRITORIES, CAN. French, H. M. Sump studies I : terrain disturbances. Ottawa : Indian and Northern Affairs Canada, 1978.

$\mathrm{P}(100) \mathrm{N} 82 \mathrm{e}$ no.6

OIL WELL DRILLING, SUBMARINE--ARCTIC REGIONS.

Jahns, H. O. Offshore outlook and technological trends in the American Arctic. London [England]: Institute of Petroleum, [1985]

S(520) qIn19ip no.85-005

OPTICAL MINERALOGY.

Shumskaia, N. I. Opredelitel'rudnykh mineralov po spektralfym krivym otrazheniia. Leningrad : Nedra, Leningradskoe otd-nie, 1985. $110 \operatorname{sh} 920$

ORE-DEPOSITS.

Guilbert, John M. The geology of ore deposits. New York : W.H. Freeman, 1985.

$410 \mathrm{G9449}$

Magakiân, I. G. Rudnye mestorozhdenita : promyshlennye tipy mestorozhdeni i metallicheskikh poleznykh iskopaemykh. Moskva : Gos. nauchno-tekhn. izd-vo lit-ry po geologii i okhrane nedr, 1955.

410 M272r MP only

Plîshchev, E. V. Geokhimi藏 i rudonosnost'gidrotermalfometasomaticheskikh obrazovanil. Leningrad : Nedra, Leningradskoe otd-nie, 1985.

410 P7i8g

Tvalchrelidze, G. A. Metallogenita zemnoĭ kory. Moskva : Nedra, 1985. 410 T898mz 

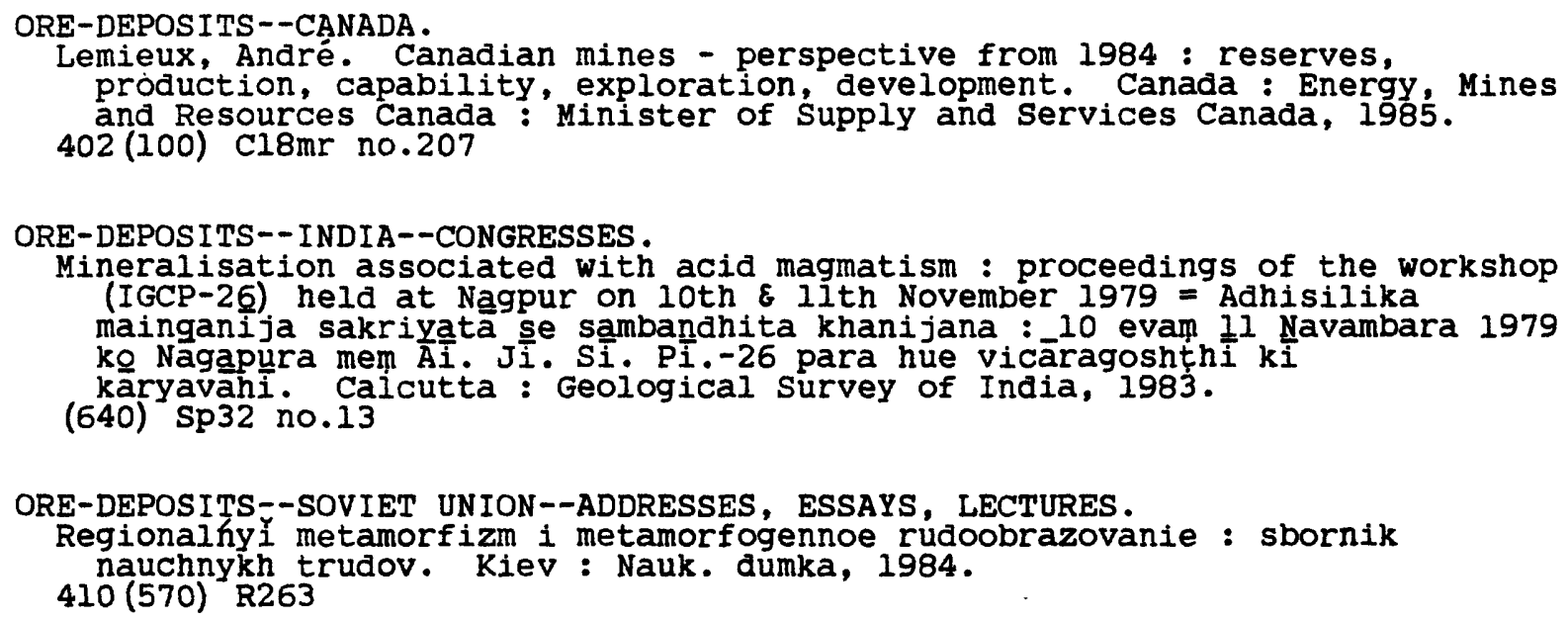

ORE-DRESSING--CANADA--COLLECTED WORKS.

Mining and mineral processing operations in Canada. Mining and mineral processing operations in Canada. Ottawa : The Agency. $402(100)$ c18mr

ORES--SAMPLING AND ESTIMATION.

Ergaliev, A. E. Metodika vybora i sravnitelfol ékonomicheskoì otsenki sistem razrabotki rudnykh mestorozhdenii. Alma-Ata : Izd-vo Nauka Kazakhskoi SSR, 1969. 415 Er38m MP only

ORGANIC GEOCHEMISTRY .

Neruchev, Sergei Germanovich. Uran i zhizn'v istorii Zemli. Leningrad : Nedra, Leningradskoe otd-nie, 1982. 439 N358u

ORGANIZATION OF PETROLEUM EXPORTING COUNTRIES--HISTORY. Terzian, Pierre. OPEC : the inside story. London : Zed, 1985. 467.7 T2 720

OROGENY--NAMIBIA--ADDRESSES, ESSAYS, LECTURES .

Evolution of the Damara Orogen of South West Africa/Namibia. lst ed. Johannesburg : Geological Society of South Africa, 1983. $G(780)$ qG293sp no.11

OSTEICHTHYES, FOSSIL.

Yadagiri, P. The piscean fauna from the Kota Formation of the PranhitaGodavari Valley, Andhra Pradesh. Calcutta : Geological Survey of India, 1980.

(640) qे v .45

OSTRACODA, FOSSIL.

Honigstein, Avraham. Senonian ostracodes from Israel. Jerusalem : Geological Survey of Israel, [1984]

(681) Is7b no.78

PALEOBOTANY--JURASSIC.

Ilína, V. I. Palinologi帒 Tûry Sibiri. Moskva : Nauka, 1985.

G(690) Akl6t vyp.638 
PALEOBOTANY--MESOZOIC.

Palinostratigrafi iâ mezozoî i kainozoîa Sibiri. Novosibirsk : Nauka, Sibirskoe otd-nie, 1985. $G(690)$ AkI $6 t$ vyp.620

PALEOCEANOGRAPHY--SOUTH ATLANTIC OCEAN--CONGRESSES.

South Atlantic paleoceanography. Cambridge ; New York : Cambridge University Press, 1985.

$203(065) \quad 5087$

PALEOECOLOGY --FRANCE--NOYANT REGION.

Charrier, Patrice. Un modèle d'évolution paléoécologique et de dynamique sédimentaire dans les faluns miocenes de Touraine : le bassin de Savigné sur Lathan (I et L). 1979-

$612(540)$ qC384m

PALEOGEOGRAPHY--ARCTIC REGIONS .

Osnovnye problemy paleogeografii pozdnego kaǐnozoîa Arktiki. Leningrad : Nedra, Leningradskoe otd-nie, 1983. (570) Nat t.190

PALEOGEOGRAPHY - -CHINA.

Chung-kuo hai lu pien chfen, hai yü chen chi hsiang yü yu chf : wan yuan ku tai - san tieh chi. Pei-ching : Ko hsueh cht pan she, 1984. $360(610) \quad f C 472$

PALEOGRAPHY--PERIODICALS.

Paleoceanography. Paleoceanography. Washington, DC : The Union, c1986$\mathrm{S}$ (200) Am285pa

PALEOMAGNETISM--SOUTH-WEST AFRICA.

Gidskehaug, Arne. Analytical methods in rock magnetism and palaeomagnetism and their applications to Mesozoic igneous rocks from South-West Africa. Bergen, Norway : Geophysical Institute, University of Bergen, 1975. $314(781)$ qG362a

PALEOMAGNETISM--SOVIET UNION .

Shevilagin, Evgenii valentinovich. Geologicheskaîa interpretaEsiia paleomagnitnykh vektorov gornykh porod. Rostov-naDonu : Izd-vo Rostovskogo un-ta, 1982.

$314(570) \operatorname{sn} 589$

PALEONTOLOGY--CENOZOIC--ADDRESSES, ESSAYS, LECTURES .

Late Cenozoic nistory of the Pacific Northwest : interdisciplinary studies on the Clarkia fossil beds of northern Idaho. San Francisco, California : Pacific Division of the American Association for the Advancement of Science, C1985.

$689(283)$ L343 MP

PALEONTOLOGY --CLASSIFICATION .

Bodylevskii, Vitalii Ivanovich. Malyi atlas rukovodiâshchikh iskopaemykh. Izd. 4 ispr. i dop. Leningrad : Nedra, Leningradskoe otdnie, 1984 .

605 B63m 1984

PALEONTOLOGY --CRETACEOUS.

Fayre, François. Die Ammoniten der unteren Kreide Patagoniens. Stuttgart : E. Schweizerbart, 1908. 659 (429) F278a 
PALEONTOLOGY--JURASSIC.

Grigialis, A. A. Foraminifery Turskikh otlozhenil iugo-zapadnol pribaltiki. Vilfius : Moksias, 1985.

$617(576)$ G876f D

PALEONTOLOGY--KENTUCKY--COLLECTED WORKS.

University of Louisvilie notes in paleontology and stratigraphy. University of Louisville notes in paleontology and stratigraphy. Louisville, $\mathrm{Ky}$. : The Dept., 1986$602(238)$ Un 3

PALEONTOLOGY --MIOCENE.

Ananiashvili, Gedevan Davydovich. Territorîâ Gruzii i smezhnye s neì regiony $\mathrm{v}$ tarkhanskoe vremia. Tbilisi : Metsniereba, 1985.

G (570) T44tn vyp.90

Bagdasarîan, K. G. Razvitie mollîuskovoí fauny Chokraka Gruzii. Tbilisi : MeEsniereba, 1965.

654 (572) Bi46r MP only

Saunders, John B. Neogene paleontology in the northern Dominican Republic : 1. Field surveys, lithology, environment, and age. Ithaca, N.Y.:

Paleontological Research Institution, [1986]

$602(200)$ B87 v.89 no.323

PALEONTOLOGY--PALEOZOIC.

Paleontologi住 i biostratigrafîa paleozoîa Sibiri. Novosibirsk : Nauka, Sibirskoe otd-nie, 1984 .

$\mathrm{G}(690)$ Akl6t vyp. 584

PALEONTOLOGY--PALEOZOIC--ADDRESSES, ESSAYS, LECTURES.

Beitrage zur allgemejnen und speziellen Palaontologie. Leipzig : Deutscher Verlag fur Grundstoffindustrie, VEB, 1985.

S (530) qF912 Ser.C no.400

PALEONTOLOGY--PRE-CAMBRIAN--ADDRESSES, ESSAYS, LECTURES .

Stratigrafiia i paleontologiîa arevneisnego fanerozoî. Moskva : Nauka, 1984 .

$681 \mathrm{St82}$

PALEONTOLOGY--RECENT--HANDBOOKS, MANUALS, ETC.

Handbook of Holocene palaeoecology and palaeohydrology. Chichester lWest Sussex] ; New York : J. Wiley, c1986.

$612 \mathrm{H} 192$

PALEONTOLOGY--TRIASSIC.

Dagys, A. S. Triasovye brakhiopody i dvustvorchatye mollîuski severa Sredneí Sibiri. Moskva : Nauka, 1985.

G (690) Akl6t vyp.633

PETROGENESIS--ADDRESSES, ESSAYS, LECTURES.

Fiziko-khimicheskie modeli petrogeneza i rudoobrazovanîa. Novosibirsk : Nauka, Sibirskoe otd-nie, 1984.

410 F588m

PETROGENESIS--ALASKA.

Himmelberg, Glen R. Petrogenesis of the ultramafic complex at the Blashke Islands, southeastern Alaska. Washington : U.S. G.P.O., 1986.

(200) E no.1662 D MP F 
PETROLEUM - COLLECTED WORKS.

Technical papers 1985 (Institute of Petroleum (Great Britain)). Technical papers published during 1985. London : The Institute, 1985. 467.9 T226 1985

PETROLEUM--GEOLOGY

Neftegazonosnost'podsolevykh otlozhenir. Moskva : Nedra, 1985.

467 N298p

Ovcharenko, A. V. Poiski i razvedka zalezhei nefti i gaza v karbonatnykh kompleksakh arevnikh platform. Moskva : Nedra, 1985.

426 ov2p

Teorîia $i$ praktika razvedki mestorozhdenil nefti i gaza. Moskva : Nedra, 1985.

426 T264

PETROLEUM--GEOLOGY--ARGENTINA--MENDOZA (PROVINCE).

Banedj-Schafie, Mehdi. Ein Beitrag zur geologisch-strukturellen

Entwicklung und zur erdolgeologischen Bewertung des sudilchen Cuyo-

Beckens, Rio Atuel-subbecken, Argentinien, Provinz Mendoza [microform]. [S.I.: S.n.]. 1984 .

MICRO- FICHE $467(520)$ B224b

PETROLEUM--GEOLOGY --CONGRESSES.

Society of Petroleum Engineers of AIME. California Regional Meeting (56th : 1986 : Dakland, Calif.). Proceedings : 56 th annual California regional meeting, April 2-4, 1986, Oakland, California. [Richardson, TX]! The Society, cl986.

467.1 (276) qSo157c 1986

PETROLEUM--GEOLOGY--HISTORY.

Blakey, Ellen Sue. Oil on their shoes : petroleum geology to 1918.

Tulsa, Okla., : American Association of Petroleum Geologists, 1985.

$467(200)$ B5870 MP

PETROLEUM--GEOLOGY--SOVIET UNION--ADDRESSES, ESSAYS, LECTURES.

obosnovanie planirovaniia geologorazvedochnykh rabot na neft'i gaz : sbornik nauchnykh trudov. Moskva : VNIGNI, 1983.

$467(570)$ M845t vyp. 249

PETROLEUM--GEOLOGY - TEXAS--MATAGORDA COUNTY.

Tyler, $N$. Facies architecture and production characteristics of strandplain reservoirs in the Frio Formation, Texas. Austin, Tex. : Bureau of Economic Geology, University of Texas at Austin, 1985.

(245) Tri no.146

PETROLEUM--GULF COAST (UNITED STATES) --CONGRESSES.

Society of Economic Paleontologists and Mineralogists. Gulf Coast Section. Foundation. Research Conference (4th : 1983 : Houston, Texas). Habitat of oil and gas in the Gulf Coast : Fourth Annual Research Conference, Gulf Coast Section Society of Economic Paleontologists and Mineralogists Foundation, Marriott West Loop, Houston, Texas, November 27-30, 1983. [Houston, Tex.?] : The Section, [1983]

G (200) G954p 1983 
PETROLEUM IN SUBMERGED LANDS--MEXICO, GULF OF--ADDRESSES, ESSAYS, LECTURES. Production and reservoir geology of selected Gulf coast oil and gas fields. New Orleans, La. : Gulf Coast Association of Geological Societies, 1985. G(209) R227 v.7

PETROLEUM INDUSTRY--ENVIRONMENTAL ASPECTS--MEXICO, GULF OF.

Gusey, William F. Petroleum production and fish and wildiffe resources : the Gulf of Mexico. New York : Shell Oil Co., Environmental Conservation Dept. , [1973?]

$585.3(062)$ G972

PETROLEUM INDUSTRY--UNITED STATES.

Riva, Joseph $P$. U.S. Conventional oil and gas production : prospects to the year 2000. Boulder, Colo.: Westview Press, 1985.

$467.7(200)$ R522u

PETROLEUM--NEW MEXICO--OTERO COUNTY.

King, William Edward: Oil and gas potential of the Tularosa Basin-otero platform-Salt Basin graben area, New Mexico and Texas. Socorro : New Mexico Bureau of Mines \& Mineral Resources, 1985. (272) qC no.198

PETROLEUM--NEW ZEALAND--DANNEVIRKE AREA.

Hicks, S. R. Basement structures relevant to the oil search in the Dannevirke region. Wellington, N.Z. : Geophysics Division, Dept. of Scientific and Industrial Research, 1980. $\mathrm{P}(890)$ qSCi2r no.172

PETROLEUM PRODUCTS- -ANALYSIS.

Fouad, M. Nabeil. The determination of lead in petroleum products : a new tentative method. London: Institute of Petroleum, [1975].

$S(520)$ qInI9ip no.75-002

PETROLEUM--WYOMING--YELLOWSTONE NATIONAL PARK REGION.

Love, J.D. Oil and gas potential of the Washakie (South Absaroka) Wilderness and adjacent study areas, Wyoming. Laramie, Wyo. : Geological Survey of Wyoming, 1985.

(282) W3r no.33

PHILIPPINE INSTITUTE OF VOLCANOLOGY AND SEISMOLOGY.

Philippine Institute of Volcanology and Seismology. PHIVoLCS observer. [S.I.]: The Institute, 1985$P(920)$ P54p

PHILIPPINE INSTITUTE OF VOLCANOLOGY--YEARBOOKS.

Philippine Institute of Volcanology and Seismology. Annual report.

Quezon City, [Philippines] : The Institute, 1983$P(920)$ v882a

PHILIPPINES. BUREAU OF MINES AND GEO-SCIENCES--PERIODICALS.

Philippines. Bureau of Mines and Geo-sciences. BMG newsietter. Manila : The Bureau.

$402(920)$ qP54b

PHILIPPINES--GEOLOGY--COLLECTED WORKS.

Geological exploration series (Cebu City, Philippines). Geological exploration series. Cebu City, Philippines : The Bureau.

$402(920)$ P54ge 
Geological investigation series (Cebu City, Philippines). Geological

investigations series. Cebu City, Philippines : The Bureau. G (920) G292

PHILIPPINES--MINERAL RESOURCES--COLLECTED WORKS.

Technical information series (Philippines. Bureau of Mines and Geo-Sciences). Technical information series. Cebu City, Philippines : The Bureau. $402(920)$ P5 $4 t$

PHOSPHATES--IDAHO--STEWART FLAT QUADRANGLE--MAPS.

Maps showing selected geology and phosphate resources of the stewart Flat quadrangle, Caribou County, Idaho. Reston, VA : U.S. Geological survey, 1984 .

M (283) 443 St $48 d--M(200) 4$ vUn3mr no.72 -- M(200) MR no.72

PHOTOGRAPHY, AERIAL--STANDARDS.

National Mapping Council of Australia. Standard specifications for black and white vertical aerial photography for line map production. Rev. April 1985. Canberra : The Council, 1985.

753.5 qN213s 1985

PHYSICAL GEOGRAPHY .

Strahler, Arthur Newell. Exercises in physical geography. 3rd ed. New York ; Chichester : Wiley, cl984.

503 St8ex 1984

PHYTOPLANKTON--HURON, LAKE.

Stevenson, R. Jan. Phytoplankton : composition, abundance and distribution in Lake Huron. Chicago, Ill. : Great Lakes National Program office, Great Lakes Fish Monitoring Program, U.S. Environmental Protection Agency, 1985. $P(200)$ En85spc

PLANETS--EXPLORATION .

Planetary mysteries : megaliths, glaciers, the face on Mars, and aboriginal areamtime. Berkeley, Calif.: North Atlantic Books, 1986.

737 P693

PLANETS--GEOLOGY--MAPS.

Witbeck, Nanci E. Geologic map of the Mare Acidalium quadrangle, Mars

(Revised).Rev. 1984. Reston, Va.: U.S. Geological Survey, 1984.

M (031) 737.3 M334g - M (200) 2 vUn $3 m$ no.1614 - M(200) I no.16i4

PLATE TECTONICS--PACIFIC OCEAN.

Engebretson, David C. Relative motions between oceanic and continental

plates in the Pacific Basin. Boulder, Colo. : The Geological Society of

America, Inc., 1985.

G (200) G29sp no.206

PLATINUM ORES--OREGON--CURRY COUNTY--MAPS.

Maps showing geochemical characteristics of platinum-group elements and gold

in rock samples from the Kalmiopsis Wilderness, Southwestern oregon.

Reston, Va.: U.S. Geological Survey, 1985.

M(285) 439 K126p -- M (200) 4 vUn3mf no.1240-F -- M(200) MF no.1240-F

PODZOL.

Khmelinin, I. N. Fosfor $\mathrm{v}$ podzolistykh pochvakh i proEsessy

transformatsii ego soedinenii. Leningrad : Nauka, Leningradskoe otdnie, 1984 .

892 K528f 
POLLEN--MORPHOLOGY --INDEXES .

Thanikaimoni, G. Quatrieme index bibliographique sur la morphologie des pollens d'angiospermes = Fourth bibliographic index to the pollen morphology of angiosperms. ler édition. Pondicherry : Institut français de Pondicherry, Section scientifique et technique, 1980.

s (640) In8t t.17

POTASSIUM-ARGON DATING--MAPS.

Potassium-argon and fission-track ages of the Sonoma volcanics in an area north of San Pablo Bay, California. Reston, Va. : U.S. Geological survey,

M(276) 315 Sa53f - M (200) 4 vUn3mf no.1753 - M (200) MF no.1753

POWER RESOURCES--AFRICA, SOUTHERN .

SADCC : energy and development to the year 2000. [London, England] : SADCC Energy Sector, cl984.

S (700) En27 no.2

POWER RESOURCES--KENYA.

Energy and development in Kenya : opportunities and constraints. Stockholm, Sweden : Beijer Institute, Royal Swedish Academy of Sciences ; Uppsala, Sweden : Scandinavian Institute of African Studies, c1984.

S (700) En27 no.1

PROSPECTING--DATA PROCESSING.

De Geoffroy, J. G. Designing optimal strategies for mineral exploration. New York: Plenum Press, cl985.

426 D34d

PROSPECTING--GEOPHYSICAL METHODS.

Alpin, L. M. Teoriâ polei, primeniâemykh $v$ razvedochnoí geofizike. Moskva : Neđra, 1985 .

426 Al75t

PROSPECTING--MANAGEMENT.

Khrustalev, N. N. Upravlenie geologorazvedochnymi rabotami v

proizvodstvennom geologicheskom obědinenii. Moskva : Nedra, 1985.

$426(570) \mathrm{K} 528 \mathrm{u}$

PROSPECTING--ONTARIO--KENORA.

Wallace, Henry. Geology of the Slate Falls area, District of Kenora

(Patricia Portion). Toronto : Ontario Ministry of Natural Resources, 1985.

$402(150)$ On82gr no.232

RADAR IN GLACIOLOGY.

Bogorodskii, V. V. Radioglaciology, Dordrecht, Holland ; Boston : $D$. Reidel Pub. Co. ; Hingham, MA, U.S.A. : Sold and distributed in the U.S.A. and Canada by Kluwer Academic, cl985. 250 B634rE

RADIOACTIVE POLLUTION OF WATER.

Horner, Jack $\mathrm{K}$. Natural radioactivity in water supplies. Boulder, Colo. : Westview Press, cl985.

$\mathrm{s}(271)$ St94 no.6 
Horner, Jack K. Natural radioactivity in water supplies. Boulder : Westview Press, 1985.

$s(271)$ St94 no.6

RADIOACTIVE PROSPEÇTING

Ekspoziționnye émanaṫ̇ionnye metody poiskov mestorozhdenil poleznykh iskopaemykh. Leningrad : Nedra, Leningradskoe otd-nie, 1985. 426.4 Ek78

Teoriđa neltronnykh metodov issledovanîa skvazhin. Moskva : Nedra, 1985. 426 T265

RADIOACTIVE PROSPECTING--SAFETY MEASURES.

Radiatsionnaia bezopasnost'pri geologorazvedochnykh rabotakh. Moskva : Nedra, 1983.

426.4 RII8

RADIOACTIVE TRACERS IN HYDROGEOLOGY.

A Study of long term (10,p3is-10,p4isyr) elemental migration in saturated clays and sediments : part II. Harwell, England : Institute of Geological Sciences, 1984.

(510) qR298 FLPU no.84-11

RADIOACTIVE WASTE DISPOSAL.

Parker, Frank L. The disposal of high-level radioactive waste, 1984 : a comparative analysis of the state-of-the-art in selected countries. Stockholm : The Institute, [1984]

795.3 qP224d

RADIOACTIVE WASTE DISPOSAL--ENVIRONMENTAL ASPECTS--SOUTHERN STATES.

Final southeastern regional geologic characterization report : executive summary. Argonne, IIl.: U.S. Department of Energy, office of Civilian Radioactive Waste Management, Crystalline Repository Project Office: Springfield, Va. : available from National Technical Information Service, [1985]

$P(200)$ En27cwd no.6

RADIOACTIVE WASTE DISPOSAL IN THE GROUND--ENVIRONMENTAL ASPECTS--WISCONSIN .

Final north central regional environmental characterization report :

executive summary, Argonne, IIl. : U.S. Dept. Of Energy, Office of

Civilian Radioactive waste Management, Crystaliine Repository Project Office ; Springfield, VA : available from National Technical Information Service, [1985]

$P(200)$ En27cwd no.5

RADIOACTIVE WASTE DISPOSAL IN THE GROUND--NORTHEASTERN STATES.

Final northeastern regional environmental characterization report : executive summary. Argonne, IIl.: U.S. Department of Energy, Office of Civilian Radioactive Waste Management, Crystalline Repository Project Office ; Springfield, Va. : available from National Technical Information Service, $P(200)$ En27cwd no.4

Final northeastern regional geological characterization report : executive summary. Argonne, Ill.: U.S. Department of Energy, Office of Civilian Radioactive Waste Management, Crystalline Repository Project Office ; Springfield, Va. : available from National Technical Information Service, [1985]

$P(200)$ En27cwd no.7 
RADIOACTIVE WASTE DISPOSAL IN THE GROUND--SOUTHERN STATES.

Final southeastern regional environmental characterization report : executive summary. Argonne, Ill. : U.S. Department of Energy, Office of Civilian Radioactive Waste Management, Crystalline Repository Project office ; Springfield, va. : available from National Technical Information Service, [1985]

$P(200)$ En27cwd no.3

Dames $\varepsilon$ Moore. Review of potential host rocks for radioactive waste disposal in the southeast United States : Triassic basin subregion. Aiken, SC: E.I. du Pont de Nemours \& Co., Savannah River Laboratory ; Springfield, Va. : Available from NTIS, 1980 .

$\mathrm{S}(200)$ D927 Sr no.1569 MP

RADIOACTIVE WASTE DISPOSAL IN THE GROUND--UNITED STATES.

Waste isolation safety assessment program : technical progress report for FY77. Richland, Washington : Pacific Northwest Laboratory ; Springfield, Va. : Available from NTIS, U.S. Dept. of Commerce, 1979.

$\mathrm{S}(200)$ qB32lpp PNL no.2642

RADIOACTIVE WASTE DISPOSAL IN THE OCEAN.

Bury, M. R. C. The of fhore disposal of radioactive waste by drilled emplacement : a feasibility study. London : Graham \& Trotman for the Commission of the European Communities, 1985.

795.3 B9580

RADIOACTIVE WASTE DISPOSAL--WASHINGTON (STATE) --HANFORD.

Roecker, J.H. Radioactive waste management at Hanford. 4th revision, August 1979: [Richland, Wash.?] : U.S. Dept. of Energy : [U.S. GPO, 1979, i.e. 1980 ].

P (200) En27rh 1979

RAIN AND RAINFALL--ARKANSAS--MAPS.

Freiwald, David A. Average annual precipitation and runoff for Arkansas, 1951-1980 Little Rock, Ark.: U.S. Geological Survey, 1984.

M (241) $7811984 \mathrm{f}$

RECLAMATION OF LAND--GREAT PLAINS.

Packer, Paul E. Rehabilitation potentials and limitations of surface-mined land in the northern Great Plains. Ogden, Utah : Intermountain Forest and Range Experiment Station, Forest Service, U. S. Dept. of Agriculture, 1974. $\mathrm{P}(200)$ A23pr

RED BEDS--TEXAS--PECOS COUNTY.

Origin of silver-copper-lead deposits in red-bed sequences of Trans-Pecos, Texas : Tertiary mineralization in Precambrian, Permian, and cretaceous sandstones. Austin, Tex. : Bureau of Economic Geology, Texas Mining and Mineral Resources Research Institute, University of Texas at Austin, 1985.

(245) T7ri no.145

REMOTE SENSING--DATA PROCESSING--CONGRESSES

Symposium on Machine Processing of Remotely sensed Data (11th : 1985 : Purdue University). Machine processing of remotely sensed data : with special emphasis on quantifying global process: models, sensor systems, and analytical methods, eleventh international symposium, June 25-27, 1985, Purdue University, Laboratory for Applications of Remote Sensing, West Lafayette, Indiana. West Lafayette, Ind. : Purdue Research Foundation ; Piscataway, N.J. : Available from IEEE Single Copy Sales, Cl985.

752.7 Sy68mrp 1985 
REMOTE SENSING--EARTH SCIENCE.

National Research Council (U.S.). Space Science Board. Remote sensing of the earth from space : a program in crisis. Washington, D.C. : National Academy Press, 1985.

$753.7 \mathrm{~N} 213 \mathrm{r}$

REMOTE SENSING--GEOLOGY.

Salisbury, John $W$. Remote sensing in the mid-infrared. [Reston, Va.] : U.S. Geological Survey, [1986]

(200) R290 no.86-167

REMOTE SENSING IN EARTH SCIENCES.

Environmental research by means of manned space stations. Arlington, Va. : Joint Publications Research Service; Springfield, Va. : Available from N.T. I.S., 1973.

753.7 Is 7 eE

RESERVOIRS--CALIFORNIA--SANTA CRUZ COUNTY.

Fogelman, Ronald P. Capacity and sedimentation of Loch Lomond Reservoir Santa Cruz County, California. Sacramento, Calif. : U.S. Geological Survey, 1985.

(200) R29o no.85-485 D MP

RESERVOIRS--IDAHO--LOCATION.

Hessing, Keith D. Potential sites for small reservoirs, October 1976.

Boise : State of Idaho, Dept. of Water Resources, [1976]

791 (283) H468p

RESERVOIRS--LINING--CONGRESSES

Symposium on Impermeable Barriers for Soil and Rock (1984 : Denver, Colo.). Hydraulic barriers in soil and rock : a symposium. Philadelphia, PA : ASTM, C1985.

768.1 Sy $684 \mathrm{~h}$

RIFTS (GEOLOGY) --GERMANY--GITTELDE.

Zinflou, Félicissime Dominique Abalo. Die Geologie des nordwestlichen Harzrandes und der Ostbegrenzung des Gittelder Grabens mit besonderer Berucksichtigung des Gebirgsbaues. [1983] $210(530) \mathrm{Z} 67 \mathrm{~g}$

RIVERS.

Pringle, Laurence P. Rivers and lakes. Alexandria, Va. : Time-Life Books, cl985.

$S$ (227) qP693 [no.16]

RIVERS--UTAH--RECREATIONAL USE.

A Methodology for estimating instream flow values for recreation. Logan, Utah : Utah Water Research Laboratory, Utah State University, 1985. $S(273)$ ut233wr no.85-01

RIVERS--WABASH RIVER (OHIO-IND.) --AERATION.

Crawford, Charles $G$. Determination of reaeration-rate coefficients of the Wabash River, Indiana, by the modified tracer technique. Indianapolis, Ind. : U.S. Geological Survey, 1985.

(200) WRi no.85-4290 D MP 
ROCK DEFORMATION--COLORADO RIVER VALLEY, COLORADO.

Grout, Marilyn A. Fracture history of the Plateau Creek and adjacent Colorado River valleys, southern Piceance Basin : implications for predicting joint patterns at depth. [Denver, Co] : U.S. Geological survey, 1985 .

(200) R290 no.85-744 D MP

ROCK MECHANICS--CONGRESSES.

U.S. Symposium on Rock Mechanics (26th : 1985 : Rapid City, S.D.). Research $\varepsilon$ engineering applications in rock masses : proceedings of the 26th U.S. Symposium on Rock Mechanics, South Dakota School of Mines and Technology, Rapid City, 26-28 June, 1985. Rotterdam ; Boston : Balkema, 1985.

401 Sy6்p 1985

ROCKS--ANALYSIS.

Sobolev, R. N. Metody petrokhimicheskikh pereschetov gornykh porod 1 mineralov. Moskva : Nedra, 1984.

155 Sol2m

ROCKS, CRYSTALLINE--MIDDLE WEST.

Final north central regional geologic characterization report : executive summary. Argonne, III. : U.S. Dept. of Energy, Office of Civilian Radioactive Waste Management, Crystalline Repository Project office Springfield, VA : available from National Technical Information Service, $[1985]$

P (200) En27cwd no.8

ROCKS, CRYSTALLINE--UKRAINE.

Ivantyshyn, Mykhailo Mykolaíovych. AkESesorni ridkişni mineraly ta rozsiiani elementy $v$ metamorfichnykh porodakh Ukrainskoho

kristalichnono shchyta. Kyiv : Nauk. dumka, 1965.

$190(571)$ IV2a MP only

ROCKS--ELECTRIC PROPERTIES--MATHEMATICAL MODELS.

Sill, W. R. A model for the crosscoupling parameters of rocks. Salt

Lake City, Utan : Dept. of Geology and Geophysics, University of Utah, [1982] $P(200)$ En27 sm

ROCKS, IGNEOUS.

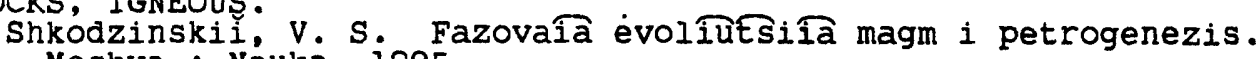
Moskva : Nauka, 1985.

170 Sh68f

ROCKS, IGNEOUS--SOVIET UNION.

Manankov, Anatoli i Vasilévich. Kinetika fazovykn perekhodov $\mathrm{v}$ bazitovykn rasplavakh i magmakh. Novosibirsk : Nauka, Sibirskoe otd-nie, 1985.

$G(690)$ Akl6t vyp.602

ROCKS, SEDIMENTARY.

Seliey, Richard $\dot{C}$. Ancient sedimentary environments and their sub-surface diagnosis. 3rd ed. Ithaca, N.Y. : Cornell University Press, 1985.

180 Se48a 1985

Stürm, Bruno Gottlieb. Die Rigi-Schuettung: Sedimentpetrographie,

Sedimentologie, Palaeogeographie, Tektonik. Zurich : Universitât zürich, [1973]

G(535) qZ8m n.F. no.19la 
ROCKS, SEDIMENTARY--MONTANA--DILLON .

Anaiytical results and sample locality maps of skarn, porphyry, and vein samples from the Dilion, Butte, and Dubois 11 po isx 2 ipo isquadrangles, Idaho-Montana. [Denver, CO] : U.S. Geological Survey, 1986.

(200) R290 no.86-37 D MP

RUNOFF--COLORADO--DENVER REGION.

Mustard, Martha $\mathrm{H}$. Runoff characteristics and washoff loads from rainfallsimulation experiments on a street surface and a native pasture in the Denver metropolitan area. Lakewood, Colo.: U.S. Geological Survey, 1985. (200) R290 no.84-820

SAMPLING (STATISTICS).

Van Ark, H. Introduction to sequential sampling as well as optimum sample size. Pretoria, South Africa: South Africa Dept. of Agriculture and Water supply, [1984]

$P(780)$ qAg83tC no.194

SANDSTONE--ADDRESSES, ESSAYS, LECTURES.

Shelf sands and sandstone reservoirs. Tulsa, Okla. : Society of Economic Paleontologists and Mineralogists, cl985.

$G(200)$ Sol5sh no.13

SATELLITES--JUPITER (PLANET)--PHOTO MAPS.

Geological survey (U.S.). Shaded relief and surface markings of the

Memphis Facula quadrangle of Ganymede. Reston, Va. : The Survey, 1984.

M (030.3) 5.1 M518g -. M(200) 2 vUn3m no.1498 - M (200) I no.1498

Geological Survey (U.S.). Shaded relief and surface markings of the Pelorus Linea region of Europa. Reston, va. : The Survey, 1984.

M(030.2) 5.1 P367g -.. M(200) 2 vUn3m no.1493 - M (200) I no.1493

SCHURZ, CARL, 1829-1906.

Lovett, Clara Maria. Carl Schurz, 1829-1906 : a biographical essay and a selective list of reading materials in English. Washington D.C. : Library of Congress, 1983. 081 Sch881

SCIENCE--CHINA--PERIODICALS.

China report (United States. Foreign Broadcast Information Service) . China report. [Fowo version]. [Arlington, Va.] : The Service. *S (610) C442ch

SCIENCE--HISTORY--PERIODICALS.

History of Science Society. Newsletter. Syracuse, N.Y. : The Society, $1972-$

$030 \mathrm{H} 628 \mathrm{n}$

SCOTT, ROBERT FALCON, 1868-1912.

Huntford, Roland. 'The last place on earth.' New York : Atheneum, 1986.

082 Sc86h

SEA ICE DRIFT--GREENLAND SEA.

Vowinckel, Eberhard. Ice transport between Greenland and Spitsbergen, and its causes. Montreal, McGill University, 1963.

$S(140)$ qM175pm no.59 
SEA-LEVEL CHANGES--CONGRESSES

International Symposium on Late Quaternary Sea-Level Changes and Coastal Evolution (1984: Mar del Plata, Agentina). Field guide = Guia de campo : International Symposium on Late Quaternary Sea-level Changes and coastal Evolution: Sept. 20 - oct. 6, 1984, Argentina. [S.1.]: IGCP, IUGS, UNESCO, 1984 .

209.1 In 839

SECONDARY RECOVERY OF OIL--CONGRESSES.

Joint SPE/DOE Symposium on Enhanced Oil Recovery (5th : 1986 : Tulsa, Okla.). Proceedings : SPE/DOE Fifth Symposium on Enhanced Oii Recovery, April 20-23, 1986, Tulsa, oklahoma. Tulsa, Okla. : The Society, 1986.

467.1 J568p 1986

SEDIMENT TRANSPORT.

Garde, R. J. Mechanics of sediment transportation and alluvial stream problems.2nd ed. New York : Wiley, 1985.

$771 \mathrm{G} 166 \mathrm{~m}$ i 985

SEDIMENT TRANSPORT--CONGRESSES.

SCOPE/UNET Workshop on the Transport of Carbon and Minerals in Major World Rivers (1983 : Hamburg, west Germany). Transport of carbon and minerals in major world rivers : part 3. Hamburg [West Germany] :.. Im Selbstverlag des Geologisch-Paläontologischen Institutes der Universität Hamburg, (1985). G (530) H17 Heft 58

SEDIMENTATION AND DEPOSITION--TEXAS.

Galloway, William E. Reservoir facies architecture in a microtidal barrier system : Frio Formation, Texas Gulf Coast. Austin, Texas : Bureau of Economic Geology, University of Texas at Austin, 1985.

(245) T7ri no.144

SEDIMENTS (GEOLOGY) - IRAO.

Al-Hashimi, Hisham A. J. Tertiary microfacies of Iraq. Baghdad : Directorate General for Geological Survey and Mineral Investigation, 1985. $150.8(665)$ A142t

SEDIMENTS (GEOLOGY) --MARYLAND--BALTIMORE--MAPS.

Map of Baltimore City showing the amount of overburden covering the underlying rocks. [Baltimore] : [Maryland Geological survey], 1935.

M (225) 213 B217m 1935

SEDIMENTS (GEOLOGY) --MARYLAND--CHESAPEAKE BAY REGION--MAPS .

Chesapeake Bay earth science atlas no. 3 : Eastern Bay and South River. [Baltimore] : Maryland Geological Survey, 1980.

$M(225) 213$ C425k3

SEDIMENTS (GEOLOGY)--NORWAY .

Olaussen, Snorre. Carbonate sedimentology of two lower Palaeozoic sequences in the Norwegian Caledonides : the parautochthonous Hole Group, Oslo region and the allochthonous Sagelvvatn Group, Troms, northern Norway. 1984 .

330 (58i) q018c

SEISMIC PROFILING--NEW MEXICO--SOCORRO REGION.

Sanford, Allan R. Seismic investigation of a magma layer in the crust beneath the Rio Grande rift near Socorro, New Mexico, and its relation to the geothermal energy potential of the region. Las Cruces, N.M. : New Mexico Energy Institute, [1975]

$295.2(272)$ Sa56s 
SEISMIC PROSPECTING.

Urupov, A. K. Opredelenie $i$ interpretaEsi otrazhennykh voln. Moskva : Nedra, 1985.

426.3 Ur80

SEISMIC PROSPECTING--NEVADA--NEVADA TEST SITE.

Carroll, R. D. Postshot seismic investigations in the vicinity of the Midas Myth Event, Ul2t.04 drift, Nevada Test Site, Nevada. Denver, Colo. : U.S. Geological Survey, 1986 .

(200) R290 no.86-98

SEISMIC REFLECTION METHOD.

Babbel, Gunter. Untersuchungen zur Bestimmung der Dämpfung seismischer Wêllen aus Reflexionsseismogrammen. Clausthal [W. Germany] : Institut für Geophysik der Technischen Universitat Clausthal, [1984]

240 B1l3u

Badley, Michael E. Practical seismic interpretation. Boston : International Human Resources Development Corporation, cl985. 426.3 qB142p MP

Galperin, E. I. Vertical seismic profiling and its exploration potential. Dordrecht ; Boston : D. Reidel ; Hingham, MA : Sold and distributed in the U.S. A. and Canada by Kluwer Acad. Pub., 1985.

240 G138vE 1985

SEISMIC WAVES.

Lee, Myung $\dot{w}$. Spectral whitening in the frequency domain. [Denver, col.] : U.S. Geological Survey, 1986.

(200) R290 no.86-108 D MP

White, J. E. Seismic waves : anisotropy, fluid saturation, and slanting interfaces. Golden, Colo. : Colorado School of Mines, [ig84]

$\mathrm{S}(271)$ C78 $\vee .79$ no:2

SEISMIC WAVES--MATHEMATICAL MODELS.

Erzhanov, Zhakan Suleimenovich. Selsmicheskie volny $v$ neodnorodnoi srede. Alma-Ata : Izd-vo Nauka KazakhskoI SSR, 1985.

295.2 Er98s

SEISMOLOGY--CALIFORNIA, SOUTHERN .

Application of private site-specific data to regional evaluation of earthquake and faulting potential in southern California. Santa Monica, $C A$ : Lamar-Merifield, \{1982]

G(276) Cl17tr no.82-3

SEISMOLOGY--CONGRESSES.

Symposium on Seismicity in Mines (1st : 1984 : Johannesburg, South Africa). Rockbursts and seismicity in mines. Johannesburg [South Africa] : South African Institute of Mining and Metallurgy, 1984.

401 (780) qSy68r

SEISMOLOGY--DATA PROCESSING.

Soldatov, V. N. Avtomatizirovannye sistemy obrabotki seľsmicheskikh

dannykh. Novosibirsk : Nauka, Sibirskoe otd-nie, 1985.

037.240 So42a 
SLOVENSKA AKADEMIJA ZNANOSTI IN UMETNOSTI. BIBLIOTEKA.

Klemencic, Marija. Biblioteka in publikacije Slovenske akademije znanosti in umetnosti $v$ letin 1952-1971 = The library and the publications of the Slovene Academy of Sciences and Arts in the years 1952-1971.

Ljubljana : [Slovenska akademija znanosti in umetnosti], 1973. $041(596.3) \mathrm{K} 675 \mathrm{~b}$ MP only

SMITHSONIAN INSTITUTION BUILDING (WASHINGTON, D.C.) .

Hafertepe, Kenneth. America's Castle: the evolution of the Smithsonian Building and its institution, 1840-1878. Washington [D.C.]: Smithsonian Institution Press, 1984.

$032(226) \mathrm{H} 122 \mathrm{a}$

SNOW SURVEYS--CENTRAL EUROPE--CONGRESSES.

Wissenschaftliche Tagung "Schneehydrologische Forschung in Mitteleuropa" (1984 : Munden, West Germany) .Schneehydrologische Forschung in Mitteleuropa = snow hydrologic research in Central Europe : Vorträge and Poster der wissenschaftlichen Tagung vom 12. bis 15 . Marz 1984 in Hann. Munden. Bonn : Deutscher Verband fur Wasserwirtschaft und Kulturbau, 1984 .

$256(500)$ W764s

SNOWPACK AUGMENTATION--NEW MEXICO--SANTA FE SKI AREA.

Smart, Alan $W$. Consumptive water use in artificial snowmaking, santa Fe

Ski Area, New Mexico. Santa Fe, N.M. : Published by New Mexico state

Engineer office in cooperation with the U.S. Forest service, 1985.

$P(272)$ qEn32tr no. 45

SOIL CHEMISTRY--COLORADO--PICEANCE CREEK WATERSHED.

Geochemical variability of soils and biogeochemical variability of plants in the Piceance Basin, Colorado. Wasnington : U.S. G.P.0., 1986.

(200) qB no.1134-E D MP F

SOIL CHEMISTRY--QUEENSLAND--FRASER ISLAND.

Little, I. P. Element concentrations in acid extracts from Fraser Island soils, carbon and nitrogen contents and their relation to age and podzol developments. [Canberrra, Australia?] : Commonwealth scientific and Industrial Research organization Australia, 1985. $P(800)$ so34ar no.76

SOIL--DENSITY--MEASUREMENT.

Schafer, G. J. Calculation methods for density measurement of soil cores by gamma ray attenuation. Lower Hutt, N.Z. : Department of scientific and Industrial Research, 1985. $P(890)$ qSo3n no.70

SOIL LIQUEFACTION--COMPUTER PROGRAMS.

Chen, Albert T. F. PETAL2, PEnetration Testing and Liquefaction : an interactive computer program. [Menlo Park, Calif.] : U.S. Geological Survey, 1986

(200) R29o no.86-178 D MP

SOIL MECHANICS.

vialov, Sergei stepanovich. Rheological fundamentals of soil mechanics. Amsterdam; New York : Elsevier, 1986.

768 D493 v.36 
SOIL MECHANICS--CONGRESSES.

Symposium on Recent Developments in Ground Improvement Techniques (1982: Bangkok, Thailand). Recent developments in ground improvement techniques : proceedings of the international symposium held at Asian Institute of Technology, Bangkok, 29 November-3 December 1982. Rotterdam [Netherlands]; Boston : A.A. Balkema, 1985. 768 Sy68r

SOILS.

Glazovskaia, M. A. Soils of the world : volume 2, soil geography. Rotterdam : A.A. Balkema, c1984.

$94 I$ G472PE V.2 D MP

SOILS--ARKANSAS--MADISON COUNTY--MAPS.

Phillips, Wallace. Soil survey of Madison County, Arkansas. [Washington, 941 D.C.?]': The Service, 1985.

SOILS--COMPOSITION--SOVIET UNION.

Kachinskii, Nikodim Antonovich; Struktura pochvy : itogi i perspektivy izucheniîa voprosa. [Moskva] : Izd-vo Moskovskogo un-ta, 1963.

$94 I(570)$ KII3s MP only

SOILS--SOUTH AFRICA--CONGRESSES.

Soil Science Society of Southern Africa. National Congress ( 9 th : $1980:$ Durban, South Africa). Proceedings, 9th National Congress, Durban, $1980=$ Handelinge, 9de Nasionale Kongres, Durban, 1980. [Pretoria]: Dept. of Agriculture and Fisheries, [1981]

$P(780)$ qÄg83tc ro.174

SOILS--SOUTH DAKOTA--MEADE COUNTY--MAPS.

Meland, Arvid C. Soil survey of Meade County, northern part, South Dakota. 941

[Washington, D.C.?]: The Service, [1986].

SOILS--TEXAS--JOHNSON COUNTY--MAPS.

Coburn, Winfred C. Soil survey of Johnson County, Texas. IWashington, D. 941 C.?]: The Service, 1985.

SOILS--TROPICS

Liang, Ta. Tropical soils, characteristics and airphoto interpretation : final report. Ithaca, N.Y.: School of Civil Engineering, Cornell University, 1964.

768 qL6I3t $D$

SOLENOIDS.

Barth, Joseph J. Developing solenoids for use with magnetic susceptibility well-logging systems. [Denver, CO]: U.S. Geological Survey, [1986]

(200) R290 no.86-115 D MP

SOLOMON ISLANDS--GEOLOGY

Allum, J. A. E. Regional photogeological interpretation of the British Solomon Islands [microform] report. Honiara, B.S.I.P. : Govt. Print. Off., 1967 .

MICRO- FICHE 753.5 (937) Al58r 1985 
SPELEOLOGY.

Melegari, Giulio E. Speleologia scientifica e esplorativa : trattato di fenomeni carsici e speleologia. Ia ed. Bologna: Calderini, 1984.

547 M483s

SPOIL BANKS--LEACHING.

Bergehalden und Grundwasser. Krefeld : Geologisches Landesamt NordrheinWestfalen, 1983.

$425(530)$ B453

STATISTICAL SERVICES.

Statistics sources : a subject guide to data on industrial, business, social, educational, financial, and other topics for the United States and internationally.loth ed. Detroit, Mich. : Gale Research Co., cl986.

R 067 qSt29 1986

STATISTICS.

Iman, Ronald L. A modern approach to statistics. New York : Wiley, cl983.

067 Im2m

STEAM--TABLES.

Haar, Lester. NBS/NRC steam tables : thermodynamic and transport properties and computer programs for vapor and liquid states of water in SI units. Washington, [D.C.] : Hemisphere Pub. Corp., c1984.

R 834 Hil2n F

STOCKS (GEOLOGY) --UTAH .

Wallace, Alan R. Mid-Tertiary shearing in the two-mica Ibapah stock, western Utah. [Denver, CO] : U.S. Geological Survey, 1986.

(200) R290 no.86-151 D MP

STRATEGIC MATERIALS--POLITICAL ASPECTS--AFRICA.

ogunbadejo, Oye. The international politics of Africa's strategic minerals. Westport, Conn. : Greenwood Press, 1985.

$403(700)$ Og8i

STRATIGRAPHIC CORRELATION--STATISTICAL METHODS.

Quantitative stratigraphy. Dordrecht ; Boston : D. Reidel Pub. Co. ; Paris : Unesco; Hingham, MA : Sold and distributed in the U.S.A. and Canada by Kluwer Academic Publishers, c1985. 303 Q25

STREAM ECOLOGY--UNITED STATES--INFORMATION SERVICES.

National Stream Alteration Team. Action in alterations. Columbia, Mo.: The Team, 1978 .

$785(200)$ N213a

STREAM-GAGING STATIONS--PENNSYLVANIA--COSTS.

Flippo, Herbert $\mathrm{N}$. Cost effectiveness of the stream-gaging program in Pennsylvania. Harrisburg, Pa. : U.S. Geological Survey, 1985. (200) WRi no.85-4077 D MP

STREAM MEASUREMENTS--ALABAMA--MOBILE REGION--MAPS.

Nelson, G. H. Maps to estimate average streamflow and headwater limits for streams in U.S. Army Corps of Engineers, Mobile District, Alabama and adjacent states. [Mobile, Ala.] : U.S. Geological Survey, 1984. M (235) 783 M 713 n 
STREAM MEASUREMENTS--CONNECTICUT.

Cervione, Michael Anthony. Streamflow information for Connecticut with applications to land-use planning. [Hartford] : Department of Environmental Protection, 1982.

$P(216)$ qW29b no.35

STREAM MEASUREMENTS--KANSAS.

Medina, K. D. Analysis of surface-water data network in Kansas for effectiveness in providing regional streamflow information. Lawrence, Kan. : U.S. Geological Survey, 1985.

(200) R290 no.85-680

STREAM MEASUREMENTS--MICHIGAN--COST EFFECTIVENESS.

Holtschlag, David $J$. Cost effectiveness of stream-gaging program in

Michigan. Lansing, Mich. : U.S. Geological Survey, 1985.

(200) WRi no.85-4293 D MP

STREAM MEASUREMENTS--TENNESSEE--BEAR CREEK WATERSHED.

Evaldi, Ronald D. Streamflow and specific-conductance data for Bear Creek, August 13, 1985, the Oak Ridge Reservation, Tennessee. Knoxville, Tenn. : U.S. Geological survey, 1986.

(200) R290 no.85-682 D MP

STREAM MEASUREMENTS--TENNESSEE--LAKE COUNTY--MAPS.

Robbins, Clarence $H$. Water budget and estimated suspended-sediment inflow for Reelfoot Lake, Obion and Lake Counties, Northwestern Tennessee, May 1984April 1985. [Nashville, Tenn.] : U.S. Geological Survey, 1985. $M(239) 783 \mathrm{R} 258 \mathrm{r}$

STREAM MEASUREMENTS--TEXAS--AUSTIN REGION.

Garner, L. E. Urban hydrology and other environmental aspects of the

Austin area : Austin Geological Society fall field trip, December 8, 1979. [Austin : Austin Geological Society, 1979].

$G(245)$ G938 [no.3]

STRIP MINING--LAW AND LEGISLATION--UNITED STATES.

United States. Congress. Senate. Committee on Interior and Insular Affairs.

surface mining reclamation. nearings before the committee on Interior and

Insular Affairs, United States Senate, Ninetieth Congress, second session on S. 3132, S. 3126 , and S. 217 : bills to provide for Federal-state cooperation in the reclamation of strip mined lands, April 30, May 1 and 2 , 1968. Washington [D.C.] U.S. Govt. Print. Off., 1968.

$P(200)$ C727ismr

SUBJECT HEADINGS.

Library of Congress. Subject Cataloging Division. Library of Congress subject headings.ioth ed. Washington [D.C.] : Library of Congress, 1986 .

045.5 qun363 1986

SUBJECT HEADINGS--AERONAUTICS.

NASA thesaurus. 1985 ed. [Washington, D.C.] : NASA, Scientific and

Technical Information Branch; Springfield, va.: Available from N.T.I.S, 1985.

$P(200)$ NA35sp no. 7053 
SUBMARINE GEOLOGY--CONGRESSES.

Offshore site investigation : proceedings of an international conference, (Offshore Site Investigation). London : Graham \& Trotman, 1985.

$203(050)$ Of 2 si 1985 MP

SUBSIDENCES (EARTH MOVEMENTS) --LIBYA--SIRTE BASIN.

Gumati, Yousef $D$. Crustal extension, subsidence, and thermal histoy of the Sirte Basin, Libya. [Columbia, South Carolina] : University of South

Carolina, Earth Sciences and Resources Institute, 1985.

G (232) OC2 no.3

SUBSIDENCES (EARTH MOVEMENTS)--LOUISIANA--BATON ROUGE REGION.

Wintz, William A. Subsidence and ground-water of ftake in the Baton Rouge area. Baton Rouge, Louisiana State University, [1970]

$S(237)$ L932wb no.6

SULPHIDES.

Foose, M. P. Setting of a magmatic sulfide occurrence in a dismembered ophiolite, southwestern oregon. [Washington, D.C.] : U.S. G.P.O., 1986. (200) E no.1626-A D MP

TECHNICAL WRITING.

Katz, Michael J. Elements of the scientific paper. New Haven : Yale University Press, cl985.

053.2 KI58e F only

TECHNOLOGY--UNITED STATES--YEARBOOKS .

Research and technology : annual report of the Goddard space Flight Center. Greenbelt, Ma. : The Center.

$P(200)$ qNA355rt

TERRESTRIAL MAGNETISM .

Rikitake, Tsuneji. Solid earth geomagnetism. Tokyo, Japan : Terra Scientific ; Dordrecht ; Boston : D. Reidel, 1985.

$S(620) \quad D 493$ v. 5

TERRESTRIAL MAGNETISM--ALASKA--FAIRBANKS REGION--OBSERVATIONS.

Preliminary geomagnetic data, College observatory, Fairbanks, Alaska : February 1986. [Denver, Col] : U.S. Geological Survey, 1986.

(200) R290 no.86-300B D MP

TERRESTRIAL MAGNETISM--CANADA--OBSERVATIONS.

Newitt, L. R. Canadian magnetic repeat stations 1962-1983 : instruments, procedures and observations = Stations de répétition magnétiques du Canada 1962-1983 : instruments, méthodes et observations. Ottawa, Can. : Division of Seismology and Geomagnetism, Earth Physics Branch, 1985.

$P(100)$ Ea76gms no.29

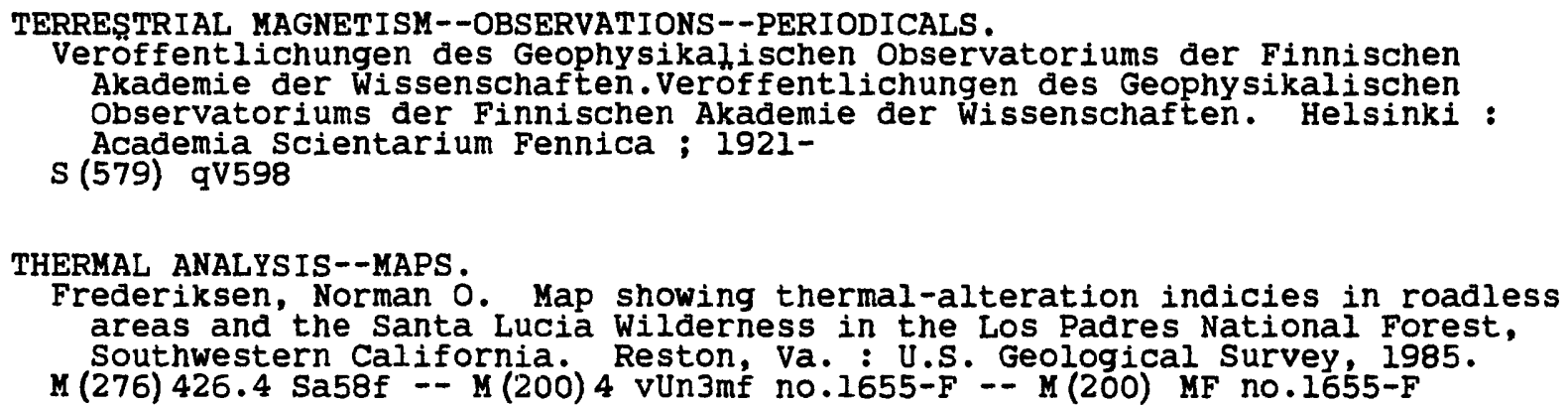


THERMODYNAMICS.

Stashchuk, M. F. Termodinamika i eë primenenie v litologii. Moskva : Nauka, 1985 .

$150.3 \mathrm{St} 28 \mathrm{t}$

Van Wylen, Gordon John. Fundamentals of classical thermodynamics. 3rd ed., SI version. New York : Wiley, c1985.

834 v388f 1985

THERMOLUMINESCENCE DATING.

Aitken, M. J. Thermoluminescence dating. U.S. ed. London ; Orlando : Academic Press, 1985.

315 Aig $3 t$

THUNDERSTORMS.

Stepanenko, Vladimir Danilovich. Radiotekhnicheskie metody issledovanî̃a groz. Leningrad : Gidrometeoizdat, 1983.

$510(570)$ St $43 r$

TIN ORES--THAILAND--ADDRESSES, ESSAYS, LECTURES.

Report of investigation : Thai-German research project. [S.1.] : The Departmént. [1985]

434 (635) R298 D

TITANIUM INDUSTRY.

Fantel, R. J. Titanium minerals availability--market economy countries : a minerals availability appraisal. [Avondale, MD]: U.S. Bureau of Mines ; Washington, D.C.: For sale by the Supt. of Docs., U.S. G.P.O., [1985] $402(200)$ Un34ic no.9061

TOURMALINE.

Dietrich, Richard Vincent. The tourmaline group. New York : Van Nostrand Reinhold, c1985.

487 D567t

TOXIC WASTE-GROUND-WATER CONTAMINATION PROGRAM (U.S.) .

Movement and fate of creosote waste in ground water, Pensacola, Florida : U.S. Geological Survey Toxic Waste-Ground-Water Contamination Program. [Washington, D.C.] : U.S. G.P.O., 1986.

(200) G no.2285 D MP

TRANSPORTATION--GREAT BRITAIN--COLLECTED WORKS.

TRRL research report (Transport and Road Research Laboratory) TRRL research report. Crowthorne, Berkshire : The Laboratory, 1984-

$P(510)$ qT687

TRILOBITES--CATALOGS AND COLLECTIONS.

Morris, S. F. Catalogue of the type and figured specimens of trilobita in the British Museum (Natural History). [London] : British Museum (Natural History) , Cl985.

662.3 qM834C

TYPHOONS.

Khain, A. P. Tropicheskie EŜiklony i ikh vzaimodeístvie s okeanom. Leningrad : Gidrometeoizdat, 1983.

$515(050)$ K526t 
UNDERWATER ACOUSTICS--BARENTS SEA--MATHEMATICAL MODELS.

Berge, Anker Monrad. Velocity analysis from seismic data and acoustic modelling of the seafloor in the Barents Sea. [1984]

$825(050)$ qB453v

UNITED STATES--MINERAL RESOURCES.

American Institute of Professional Geologists. Mineral resources position

statement : condensed version. Golden, Colo. : The Institute, [1979]

$403(200)$ Am $35 \mathrm{mc}$

UNITES STATES--MINERAL RESOURCES.

American Institute of Professional Geologists. Mineral resources position statement : full-length version. Golden, Colo : The Institute, [1979] $403(200)$ Am35mf

UNIVERSITY OF RHODE ISLAND SEA GRANT PROGRAM.

University of Rnode Island Sea Grant Program. A Report on the University

of Rhode Island Sea Grant Program. Narragansett, R.I. : URI, Marine

Advisory Service, Publications unit.

$S(215)$ Un $3 r$

URANIUM--ÄPPALACHIAN MOUNTAINS REGION.

Gabelman, John Warren. Uranium in the Appalachian mobile belt.

Wasnington, D.C. : U.S. Atomic Energy Commission, Division of Raw Materials ; for sale by the supt. of Docs., U.S. G.P.O., [1968].

815 Un31P RME

URANIUM ORES--ADDRESSES, ESSAYS, LECTURES .

vein type uranium deposits : report of the Working Group on Uranium Geology. Vienna : The Agency, 1986.

439 qV536

URBAN RUNOFF.

Characterization of urban runoff. New Brunswick, N.J. : Water Resources Research Institute, Rutgers University, 1976.

$781(200)$ C 372

UTAH--GEOLOGY--GARFIELD COUNTY - MAPS.

Geologic map of the Little Rockies Wilderness Study Area and the Mt. Hillers and Mt. Pennell Study Areas, and vicinity, Garfield County, Utan. Reston, Va. : U.S. Geological survey, 1985.

M(273) 2 Li271 - M M(200) 4 vUn3mf no.1776-B -- M(200) MF no.1776-B

UTAH--GEOLOGY--LUCIN QUADRANGLE--MAPS.

Miller, David M. Geologic map of the Lucin quadrangle, Box Elder County, Utah. Salt Lake City, Utah : Utah Geological and Mineral Survey, 1985. M (273) 2 L963m

VENEZUELA--GEOLOGY--PERIODICALS .

Boletín de geociencias (Caracas, Venezuela). Boletin de geociencias. Caracas, Venezuela : El Departamento, 1985-

G (470) qB637

VENEZUELA--MINERAL RESOURCES--PERIODICALS .

Energia y minas (Caracas, Venezuela). Energia y minas. Caracas, Venezuela : La Oficina.

$402(470)$ En 27 


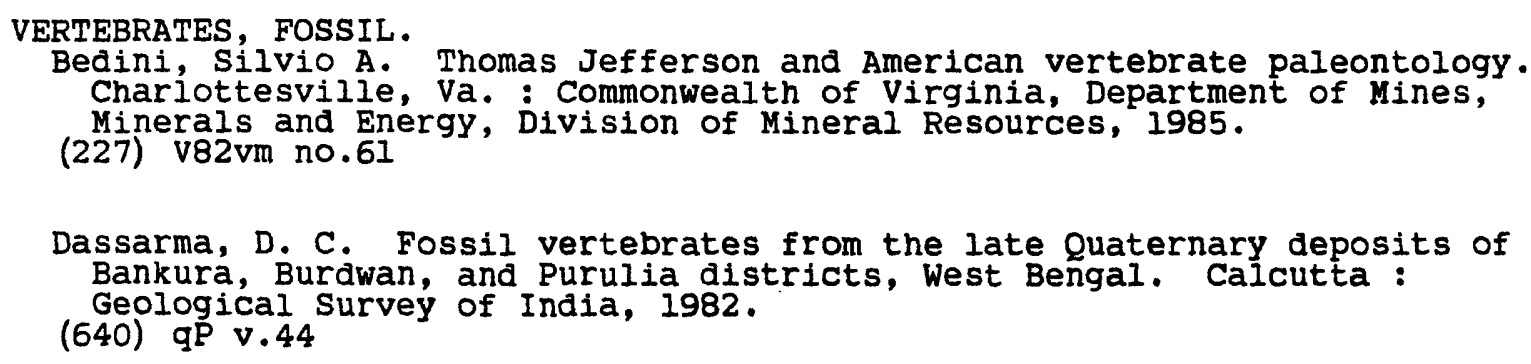

VIDEO DISCS--PERIODICALS.

optical information systems. Optical information systems. Westport, CT: Meckler Pub., cl986040 V 668

VOLCANISM.

Sharfman, V. S. Paleovulkanologicheskie karty : sostavlenie kart 1 legend k nim. Moskva : Nedra, 1984.

$360 \sin 23 p$

VOLCANISM--FLUID DYNAMICS--ADDRESSES, ESSAYS, LECTURES.

Processes in magma chambers. Amsterdam : Elsevier, 1985.

$220 \mathrm{~J} 826 \mathrm{v} .24$ no.1-2

VOLCANISM--JAN MAYEN ISLAND.

Imsland, páll. Petrology, mineralogy and evolution of the Jan Mayen magma system. Reykjavik : Prentsmiłjan Oddi. 1984.

$220(980)$ Im8p

VOLCANISM--TEXAS--AUSTIN AREA.

Young, Keith. Cretaceous volcanism in the Austin area, Texas : Austin Geological society, Spring, 1981 field trip.Rev. ed. Fall 1982 . Austin, Tex.: Austin Geological Society, 1982.

$\mathrm{G}(245)$ G938 no.4

VOLCANOES.

Krafft, Katia, volcans et tremblements de terre. [Paris : Editions des] Deux coqs dior, [1971, repr.1979]

220 C764V 1979

Rittmann, Alfred. I vulcani. Novara [Italy] : Istituto geografico De Agostini, 1976.

220 qR5I7vu

VOLCANOES--JAPAN .

Hisamaro, Oka. Explosion of Myōjin Reef. [Tokyo, Japan : U.S. Geological Survey, Pacific Geological surveys, 1952]

$209(900)$ qun33pr [no.485]

VOLCANOES--PHILIPPINES--CONGRESSES.

Seminar Workshop on Philippine Volcanoes and Volcanic Terranes (1st : 1982 : Quezon City, Philippines). The First Seminar Workshop on Philippine

Volcanoes and Volcanic Terranes, December 13-14, 1982, Asian Institute of Tourism. [Quezon City, Philippines]: Philippine Institute of Volcanology, 1982 ?

$220(920)$ Se52f 
VOLCANOES--WASHINGTON (STATE)--SAINT HELENS, MOUNT.

Hoblitt, R. P. Observations of the eruptions of July 22 and August 7, 1980, at Mount St. Helens, Washington. Washington : U.S. G.P.O. ; For sale by the Supt. of Docs., U.S. G.P.O., 1986.

(200) qB no. $1335 \mathrm{D}$ MP F

WATER CHEMISTRY.

Waddell, K. M. Chemical and physical characteristics of water and sediment in Scofield Reservoir, Carbon County, Utah. Washington: U.S. G.P.O., 1985.

(200) G no.2247 D MP

WATER CHEMISTRY--SOVIET UNION.

Nesterov, K. V. Kristallomorficheskie profâvleni住 mineralizaEsii

prirodnykh vod. Rostov-na-Donu : Izd-vo Rostovskogo un-ta, 1983. $797(570)$ N $376 \mathrm{k}$

WATER CONSERVATION--RESEARCH--UNITED STATES.

OWRT water reuse research and development program : project descriptions.

[Washington, D.C.?] : Dept. of the Interior, Office of Water Research and Technology, 1981 .

$799.7(200)$ Un̉ 3801981

WATER--POLLUTION--ENVIRONMENTAL ASPECTS--CONGRESSES .

Symposium on Aquatic Toxicology (8th : 1984 : Fort Mitchell, Ky.). Aquatic toxicology and hazard assessment : eighth symposium : a symposium. Philadelphia, PA : ASTM, Cl985. 795 Sy68a 1985

WATER--POLLUTION--NEW YORK--BUFFALO REGION.

Kuzia, Edward J. Investigation of polycyclic aromatic nydrocarbon

discharges to water in the vicinity of Buffalo, New york. Chicago, Ill. : Great Lakes National Program Office, U.S. Environmental Protection Agency, 1985.

$P(200)$ En85ki

WATER--POLLUTION--SOUTHERN STATES--CONGRESSES.

A report on control of water pollution from toxic wastes in the southeast. [Raleigh] : Water Resources Research Institute, University of North Carolina, 1982?

$\mathrm{S}(230)$ So88 v.3 no.1

WATER--POLLUTION--TEXAS--DALLAS.

Urban storm runoff sampling program : storm of February 11, 1977. Dallas, Tex. : DWU Operations Analysis Division, [1977]

$781(245)$ Ur2 D

WATER--PURIF ICATION--CONGRESSES.

Advanced treatment technologies for removal and disposal of micropollutants : proceedings of a seminar held in Antwerp, Belgium, 24-25 september 1984 . oxford : Pergamon. 1986.

795 P944 v.18 no.1

WATER QUALITY--ARKANSAS--MAPS.

Fitzpatrick, Daniel J. Occurrence of saltwater in the alluvial aquifer in the Boeuf-Tensas Basin, Arkansas. Little Rock, Ark. : U.S. Geological Survey, 1985.

M (24I) 495 B633f 
WATER QUALITY--CALIFORNIA--LIVERMORE-AMADOR VALLEY.

Sorenson, Stephen $K$. Water-quality conditions and an evaluation of groundand surface-water sampling programs in the Livermore-Amador Valley,

California. Sacramento, Calif. : U.S. Geological Survey, 1985.

(200) WRi no.84-4352 D MP

WATER QUALITY--CALIFORNIA--SAN FERNANDO VALLEY.

Setmire, James G. A conceptual ground-water-quality monitoring network for San Fernando Valley, California. Sacramento, Calif. : U.S. Geological Survey, 1985 .

(200) WRi no.84-4128 D MP

WATER QUALITY--FLORIDA--DADE COUNTY--MAPS.

Klein, Howard. Synopsis of saltwater intrusion in Dade County, Florida, through 1984. [Tallahassee, Fla.] : U.S. Geological Survey, 1985. M (234) 495 D $124 \mathrm{k}$

WATER QUALITY--LAW AND LEGISLATION--WEST VIRGINIA.

West Virginia. Division of Water Resources. Administrative regulations of the State of West Virginia for water quality criteria on inter-and intrastate streams and the proposed regulations to facilitate the state's implementation of the national pollutant discharge elimination system (NPDES) : proposed. Charleston, WV: State Water Resources Board, [1979?] 798 (228) W532a 1979

WATER QUALITY MANAGEMENT--GREAT LAKES.

Wise, Peter L. A five year program strategy for the Great Lakes National Program Office of the U.S. Environmental Protection Agency, 1986-1990. Chicago, Ill. : Great Lakes National Program Office, U.S. Environmental Protection Agency ; 1985.

P (200) En85wfy

WATER QUALITY MANAGEMENT--GREAT LAKES REGION--CONGRESSES.

Onio State 'University. Water Resources Center. Symposium (3rd : 1967 : Ohio State University). Systems approach to water quality in the Great Lakes : proceedings of the Third Annual Symposium on water Resources Research of the Ohio State University Water Resources Center. IColumbus : Onio State University], 1967.

797 (067) Oh3s

WATER QUALITY--NEBRASKA--LINCOLN REGION.

Pettijonn, Robert A. Water-quality variations in Antelope Creek and Deadmans Run, Lincoln, Nebraska. Lincoln, Neb. : U.S. Geological Survey, 1985.

(200) WRi no.85-4153 D MP

WATER QUALITY--NEVADA--TRUCKEE RIVER BASIN.

Garcia, Kerry T. Water-quality characteristics and nutrient and suspendedsediment loads, Carson River and Truckee Canal, western Nevada, water year 1980. Carson City, Nev. : U.S. Geological Survey, 1986.

(200) WRi no.85-4147'D MP

WATER QUALITY--NEW HAMPSHIRE--SACO RIVER VALLEY.

Johnson, Carole D. Ground-water quality data for the Saco River Valley

glacial aquifer from Bartlett, New Hampshire to Fryeburg, Maine : JuIy 1984

through November 1985. Augusta, Me. : U.S. Geological Survey, 1986.

(200) R290 no.86-129 
WATER QUALITY--PENNSYLVANIA--FAYETTE COUNTY.

Stump, Donald E. Effects of surface mining on streamflow, suspendedsediment, and water quality in the Stony Fork drainage basin, Fayette County, Pennsylvania. Harrisburg, Pa. : U.S. Geological Survey, 1985.
(200) WRi no.84-4362 D MP

WATER QUALITY--WASHINGTON (STATE) --PUGET SOUND REGION--MAPS .

Gilliom, Robert J. Lake-water quality and land-use relationships for selected lakes in the port Townsend quadrangle, Puget Sound Region, Washington. Reston, Va. : U.S. Geological Survey, 1983. M (284) 797 P838g

WATER QUALITY--WASHINGTON (STATE)--PUGET SOUND REGION. Turney, Gary L quality of ground water in the Puget sound region, Washington, ig8I. Tacoma, Wash. : U.S. Geological survey, 1986. (200) WRi no.84-4258 D MP

WATER RESOURCES DEVELOPMENT.

New Zealand. Water and Soil Division. Review of water and soil conservation research 1982/83. Wellington, N.z. : Published for the National Water and Soil Conservation Authority by the Water and soil Directorate, Ministry of Works and Development, 1985.

$P(890)$ qW292mp no.84

WATER RESOURCES DEVELOPMENT--INDIA--CONGRESSES.

National Symposium on Planning and Design of Water Resource Systems (1983 : Patna University). Proceedings : National Symposium on Planning and Design of Water Resource Systems, February 10-12, 1983. Patna [India] : The Programme, [1983]

$784.1(640)$ N213p

WATER RESOURCES DEVELOPMENT--JAPAN.

Water resources in Japan : present state of water resources development, conservation and utilization. [Tokyo, Japan]: The Dept., 1984. $784(620)$ qW292

WATER RESOURCES DEVELOPMENT--NIGERIA--BENUE.

Balasha-Jalon Consultants \& Engineers Ltd. Master plan of water resources development. Haifa, Israel : Balasha-Jalon Consultants \& Engineers Ltd, [1970]

$784(752) \quad$ M 393

WATER RESOURCES DEVELOPMENT--PAPUA NEW GUINEA--COLLECTED WORKS.

BWR report (Papua New Guinea. Bureau of Water Resources). Report. Port Moresby, Papua New Guinea : The Bureau.

$P(930)$ qW288b

WATER RESOURCES DEVELOPMENT--PERIODICALS .

International Water Resources Association. IWRA. Urbana, IIl. : The Association, 1985-

784 In8w

WATER REUSE--CALIFORNIA.

Fowler, Lloyd C. Status of water reclamation technologies as they apply to the Kesterson problem and related problems in California : a white paper. Irvine, CA : California Association of Reclamation Entities of Water ; Springfield, Va. : National Water Supply Improvement Association, [1986] $794(276)$ F832s 
WATER REUSE--CALIFORNIA--SAN DIEGO COUNTY .

Izbicki, John A. Evaluation of the Mission, Santee, and Tijuana hydrologic subareas for reclaimed-water use, San Diego County, California.

Sacramento, Calif. : U.S. Geological Survey, [1985]

(200) WRi no.85-4032 D MP

WATER-SUPPLY ENGINEERING.

Twort, A. C. Water supply. 3rd ed. London : Edward Arnold, 1985.

780 T936t 1985

WATER TABLE--CALIFORNIA--DEATH VALLEY REGION.

Winograd, Isaac Judah. Water-table decline in the south-central Great

Basin during the Quaternary period: implications for toxic-waste disposal. Reston, Va. : U.S. Geological survey, 1986.

(200) R29o no.85-697

WATER, UNDERGROUND.

Diunin, V. I. Metodika izucheni住 glubokogo podzemnogo stoka.

Moskva : Nedra, 1985. $490 \mathrm{D} 638 \mathrm{~m}$

Metody okhrany podzemnykh vod ot zagriâzneni价 1 istoshcheni价. Moskva : Nedra, 1985 . $494 \mathrm{M} 567$

WATER, UNDERGROUND--ADDRESSES, ESSAYS, LECTURES.

Issledovaniîa podzemnogo stoka. Leningrad : Gidrometeoizdat, 1982.

$780(570)$ R92t vyp.286

WATER, UNDERGROUND--ARIZONA--GILA RIVER REGION--MAPS.

Thomsen, B. W. Ground-water conditions in and near the Gila River Indian Reservation, South-central Arizona, [Tucson, Ariz.] : U.S. Geological

Survey, [1985]

M (274) $49^{\prime} \mathrm{G} 372 \mathrm{t}$

WATER, UNDERGROUND--ARKANSAS--MAPS .

Edds, Joe. Maps showing altitude of the potentiometric surface and changes in water level of the Sparta sand and Memphis sand aquifers in Eastern

Arkansas, spring 1984. Little Rock, Ark.: U.S. Geological Survey, [1985]. $M(241) 49$ Sp25e 1984

Edds, Joe. Maps showing altitude of the potentiometric surface and changes in water level of the Sparta sand and Memphis sand aquifers in Eastern Arkansas, spring 1983. [Little Rock, Ark.] : U.S. Geological Survey, [1984].

$M(241) 49$ sp25e 1983

Edds, Joe. Maps showing altitude of the potentiometric surface and changes in water levels of the alluvial aquifer in eastern Arkansas, Spring 1983.

[Litte Rock, Ark.] : U.S. Geological survey, [1984]

M (241) 49 Ea77e

WATER, UNDERGROUND--ARTIFICIAL RECHARGE.

Kimbler, Oscar K. Cyclic storage of fresh water in saline aquifers.

Baton Rouge : Louisiana State University, [1975]

$S(237)$ L932wb no.10 
WATER, UNDERGROUND--ARTIFICIAL RECHARGE--CONNECTICUT.

Handman, Elinor $H$. Delineating recharge areas for stratified-drift aquifers in Connecticut with geologic and topographic maps, Hartford, Conn.: U.S. Geological Survey, 1986.

(200) WRi no.83-4230 D MP

WATER, UNDERGROUND--CALIFORNIA--CARPINTERIA REGION--MAPS.

Maltby, Dorothy. Map of the Carpinteria area and vicinity, Santa Barbara County, California: Showing water-level contours for March 1982. Sacramento, Ca. : U.S. Geological Survey, 1984. M (276) 49 C228m

WATER, UNDERGROUND--CALIFORNIA--SANTA BARBARA COUNTY.

Hami in, Scott N. Ground-water quality in the Santa Rita, Buellton, and Los Olivos hyarologic subareas of the Santa Ynez River basin, Santa Barbara County, California. Sacramento, Calif. : U.S. Geological Survey, 1985. (200) WRi no.84-4I3I D MP

WATER, UNDERGROUND--CALIFORNIA--SANTA BARBARA COUNTY--MAPS .

Moyle, W. R. Map of the Carpinteria area and vicinity, Santa Barbara County, California : showing water-level contours for March 1983 and net change in water level between March 1982 and March 1983. Sacramento, Ca. : U.S. Geological Survey, 1984 .

M (276) 49 C228m 1983

WATER, UNDERGROUND--COLORADO--PUEBLO REGION .

Banta, Edward R. The Dakota aquifer near Pueblo, Colorado : faults and flow patterns. Lakewood, Colo. : U.S. Geological Survey, 1985.

(200) WRi no.85-4186 D MP

WATER, UNDERGROUND--COLORADO--RIO BLANCO COUNTY.

Van Liew, William P. Preliminary assessment of the ground-water resources of the alluvial aquifer, white River valley, Rio Blanco county, Colorado. Lakewood, Colo. : U.S. Geological Survey, Water Resources Division, 1985. (200) WRi no.84-4307 D MP

WATER, UNDERGROUND--FLORIDA.

Ryder, Paul D. Hydrology of the Floridan aquifer system in west-central Florida. Washington: U.S. G.P.O. ; Arlington, VA: For sale by the Branch of Distribution, U.S. Geological Survey, 1985.

(200) qB no.1403-F

WATER, UNDERGROUND--FLORIDA--WITHLACOOCHEE RIVER WATERSHED--MAPS.

Anderson, warren. Geohydrology of the Floridan aquifer in the Withlacoochee River basin of the Southwest Florida Water Management District. Tallahassee, Fla.: U.S. Geological Survey, 1982.

M (234) 49 W777a -- (200) R290 no.82-331 -- (200) R290 no.82-33i

WATER, UNDERGROUND--IDAHO--CARIBOU COUNTY--MAPS.

Young, $H$. W. Water-table contours, directions of ground-water movement, and ground-water divide, October 1983, in Gem Valley, southeastern Idaho. [Boise, Idaho] : U.S. Geological Survey, [1984].

$M(283) 49^{\prime}$ G284y

WATER, UNDERGROUND--IDAHO--CASSIA COUNTY--MAPS.

Young, $\mathrm{H}$. W. Potentiometric-surface contours, directions of ground-water movement, and perched-water zones, Dakley Fan, Southeastern Idaho, MarchApri] 1984. [Boise, Idaho] : U.S. Geological Survey, 1984.

M (283) 49 Oa4y 
WATER, UNDERGROUND--IDAHO--MAPS .

Young, $\mathrm{H}$. W. Water-table contours, directions of ground-water movement, and measurements of inflow to American Falls Reservoir, Southeastern Idaho, Apri1 1984. [Boise, Idaho] : U.S. Geological Survey, 1984.

M (283) 49 Am35y

WATER, UNDERGROUND--KANSAS.

Burnett, Robert D. Simulation of the effects of management alternatives on the stream-aquifer system, South Fork Solomon River valley between Webster Reservoir and Waconda Lake, north-central Kansas. Lawrence, Kan.: U.S. Geological Survey, 1985 .

(200) WRi no.85-4200 D MP

Olea, Ricardo A. Optimization of the High Plains Aquifer Observation Network, Kansas. Lawrence, Kansas : Kansas Geological Survey, 1982.

(267) K4gws no.7

Watts, Kenneth R. Potential hydrologic effects of ground-water withdrawals from the Dakota aquifer, southwestern Kansas. Lawrence, Kan. : U.S. Geological Survey, 1985 .

(200) R290 no.85-567 D MP

WATER, UNDERGROUND--KANSAS--HIGH PLAINS REGION--MAPS .

Pabst, Marilyn E. Percentage change in saturated thickness of the High plains aquifer, west-central Kansas, 1950 to average 1982-84. [Lawrence, Kansas] : U.S. Geological Survey, 1984.

M (267) 49 W522p 1984

WATER, UNDERGROUND--KANSAS--MATHEMATICAL MODELS.

Colarullo, Susan J. Demonstrative model for identifying ground-watermanagement options in a contaminated aquifer / by susan J. Colarulio, Manoutchehr Heidari, Thomas Maddock III. Lawrence, Kan. : Kansas Geological survey, 1985 .

(267) K4gws no.8

WATER, UNDERGROUND--LOUISIANA--CHARTS, DIAGRAMS, ETC.

Whiteman, C. D. Geohyarologic sections, Northern Louisiana. [Reston, Va.] : U.S. Geological Survey, 1984 .

M $(237) 49$ N815W

WATER, UNDERGROUND--LOUISIANA--MAPS.

Martin, Angel. Generalized potentiometric surface of aquifers of Pleistocene age, Southern Louisiana, 1980. [Baton Rouge, La.] : U.S. Geological Survey, 1985 .

M (237) 49 So88m

Martin, Angel. Generalized potentiometric surface of the Evangeline and equivalent aquifers in Louisiana, 1980. [Baton Rouge, La.] : U.S. Geological Survey, 1985.

M (237) $491985 \mathrm{~m}$

WATER, UNDERGROUND--MARYLAND--ANNAPOLIS REGION--MAPS .

The difference between the potentiometric surfaces of the Magothy aquifer of September 1982 and September 1984 in southern Maryland. Towson, Md. : U.S. Geological Survey, [1985].

M (225) 49 M275d Sept. 1984 
Mack, Frederick K. Map showing the difference between the potentiometric surfaces of the Magothy aquifer of September 1975 and September 1982 in Southern Maryland. Towson, Md. : U.S. Geological Survey, 1982.

M (225) 49 M275d Sept. 1982

Mack, Frederick K. Map showing the potentiometric surface of the Magothy aquifer in Southern Maryland, September 1982. Towson, Ma. : U.S. Geological Survey, 1982.

M (225) 49 M275p Sept. 1982

Mack, Frederick K. The potentiometric surface of the Magothy aquifer in Southern Maryland, September 1984. Towson, Md. : U.S. Geological Survey, 1985 .

M (225) 49 M275p Sept. 1984

WATER, UNDERGROUND--MARYLAND--BALTIMORE REGION .

Chapelle, Frank. Hydrogeology, digital solute-transport simulation, and geochemistry of the lower Cretaceous aquifer system near Baltimore, Maryland. Baltimore, Md.: Maryland Geological Survey 1985.

(225) qM4ri no.43

WATER, UNDERGROUND--MARYLAND--CARROLL COUNTY--MAPS.

Weigle, James Montgomery. Hydrogeologic atlas, Union Bridge and Woodsboro quadrangles, Carroll County, Maryland. [Baltimore, Md.]: Maryland Geological Survey, 1981.

M (225) 49 Un $3 w$

Weigle, James Montgomery. Hydrogeologic atlas, Taneytown and Emmitsburg quadrangle, Carroll County, Maryland. [Baltimore, Md.] : Maryland Geological survey, 1981 .

M(225) 49 T155W

WATER, UNDERGROUND--MARYLAND--CHESAPEAKE BAY REGION--MAPS.

Preliminary map showing the difference between the potentiometric surfaces of the Aquia aquifer of September 1982 and September 1984 in southern Maryland. [Towson, Md.] : U.S. Geological Survey, [1985].

M (225) 49 Aq52d Sept. 1984

Preliminary map showing the potentiometric surface of the Aquia aquifer in southern Maryland, September 1984. [Towson, Md.]: U.S. Geological Survey, $[1985]$.

M (225) 49 Aq52p Sept. 1984

WATER, UNDERGROUND--MARYLAND--FINKSBURG QUADRANGLE--MAPS.

Williams, James Frank. Hyarogeologic atlas, Finksburg quadrangle, Carroll County, Maryland. [Baltimore, Md.] : Maryland Geological Survey, 1981.

M (225) 49 F 495 w

WATER, UNDERGROUND--MARYLAND--HEREFORD QUADRANGLE--MAPS .

Duigon, Mark T. Hydrogeologic atlas, Hereford quadrangle, Baltimore County, Maryland. [Baltimore, Md.] : Maryland Geological Survey, 1981.

M (225) 49 H422d

WATER, UNDERGROUND--MARYLAND--MAPS .

Mack, Frederick $K$. The potentiometric surface of the Magothy aquifer in southern Maryland, September 1983. Towson, Ma. : U.S. Geological Survey, 1985.

M (225) 49 M275p Sept. 1983 
WATER, UNDERGROUND--MATHEMATICAL MODELS.

Kinzelbach, Wolfgang. Groundwater modelling : an introduction with sample programs in BASIC. Amsterdam; New York: Elsevier Science Publishers, 1986.

$780 \mathrm{D} 494 \quad \mathrm{v} .25$

Walton, William Clarence. Practical aspects of groundwater modeling : flow, mass and heat transport, and subsidence : analytical and computer models.

2nd ed. Worthington, Ohio: National Water Well Association, 1985.

490 WI78p 1985

WATER, UNDERGROUND--MINNESOTA--MINNEAPOLIS REGION--MAPS .

Ruhi, J. F. Hyarogeologic and water-quality characteristics of the St. Peter aquifer, Southeast Minnesota. [St. Paul, Minnesota] : U.S. Geological Survey, 1983.

M(26I) 49 St $78 \mathrm{r}$

Ruhl, J. F. Hydrogeologic and water-quality characteristics of the Prairie du Chien-Jordan aquifer, Southeast Minnesota. St. Paul, Minn. : U.S. Geological Survey, 1983.

M (261) 49 P885r

WATER, UNDERGROUND--MISSISSIPPI EMBAYMENT.

Ground-water quality data from the northern Mississippi embayment--Arkansas, Missouri, Kentucky, Tennessee, and Mississippi. Nashville, Tenn.: U.S. Geological Survey, 1985.

(200) R290 no.85-683 D MP

WATER, UNDERGROUND--MISSISSIPPI--MAPS.

Darden, Daphne. Potentiometric map of the Ripley aquifers in Northeastern Mississippi, Fall 1982. Jackson, Ms.: U.S. Geological survey, 1985.

M(236) 49 N815d 1982

Darden, Daphne. Potentiometric map of the Paleozoic aquifer in northeastern Mississippi, November and December 1982. Jackson, Mississippi: U.S. Geological Survey, 1984

M(23б) 49 N815d Dec.1982

WAFER, UADERGROLND--MONTANA.

M=E vonds, N. E. Dotentiai effects of surface coal mining on the hysro-ogy of the itizie Bear Creek area, Yoorhead coal field, southeastern Morzana. Hezera, Mor:. : J.s. Geological Survey, [1986]

(202) WR: $: 0.35-42012$ M?

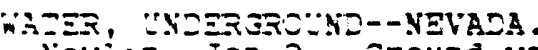

ijw-i., Icr. 0 . Ground-water quality in Nevada : a croposed monizoring

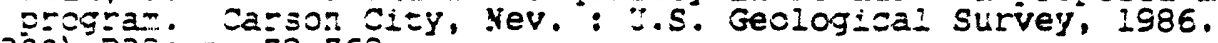

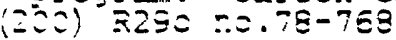

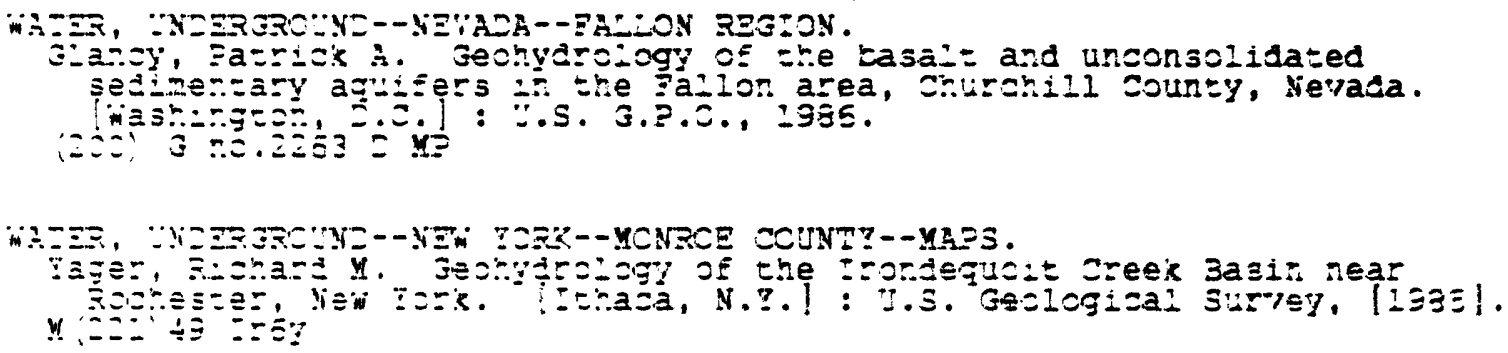


WATER, UNDERGROUND--NEW YORK (STATE) --SARATOGA COUNTY--MAPS.

Reynolds, Richard J. Hydrogeology of the Clifton Park area, Saratoga County, New York. Albany, N.Y. : U.S. Geological Survey, 1985. M (221) $49^{\prime} \mathrm{C} 613 \mathrm{r}$

WATER, UNDERGROUND--NEW YORK (STATE) --STEUBEN COUNTY--MAPS. Geohydrology of the valley-fill aquifer in the Bath area, Lower cohocton River, Steuben County, New York. [Ithaca, N.Y.] : U.S. Geological Survey, 1984 .

M (221) 49 B322p

WATER, UNDERGROUND--PALO DURO CREEK WATERSHED, TEXAS.

orr, Elizabeth D. Investigation of underpressuring in the Deep-Basin Brine Aquifer, Palo Duro Basin, Texas, Austin, Tex. : Bureau of Economic Geology, University of Texas at Austin, 1985. (245) qT7ge no.85-1

WATER, UNDERGROUND--PENNSYLVANIA--CHESTER COUNTY--MAPS. Wood, Charles R. Ground-water levels in the Lower Palleozoic carbonate rocks of Western Chester Valley, Chester County, Pennsylvania, November 1984. [Reston, Va.] : U.S. Geological Survey, [1985].

M (223) 49 C426w 1984

WATER, UNDERGROUND--POLLUTION--FLORIDA--MAPS.

Healy, Henry $G$. Occurrence of beds of low hydraulic conductivity in surficial deposits of Florida. [Tallahassee, Fla.] : U.S. Geological Survey, 1984. M (234) $4941984 \mathrm{~h}$

WATER, UNDERGROUND--PUERTO RICO--VEGA ALTA QUADRANGLE--MAPS.

Torres-Sierra, Heriberto. Potentiometric surface of the upper limestone aquifer in the Dorado-Vega Alta area, North-central Puerto Rico, February 1983. San Juan, P.R. : U.S. Geological Survey, 1985. M (394) 49 D725t

WATER, UNDERGROUND--SOUTH CAROLINA--MAPS.

Aucott, Walter R. Potentiometric surfaces of November 1982 and declines in the potentiometric surfaces between the period prior to development and November 1982 for the coastal plain aquifers of South Carolina. Columbia, S.C. : U.S. Geological Survey, 1985.

M (232) $491982 a$

Aucott, Walter $R$. Potentiometric surfaces of the coastal plain aquifers of South Carolina prior to development. Columbia, S.C.: U.S. Geological Survey, 1985.

M (232) $49^{\prime} 1985 a$

WATER, UNDERGROUND--SOUTHEASTERN STATES--MAPS.

Approximate potentiometric surface for the aquifer unit A2, southeastern coastal plain aquifer system of the United States, prior to development. [Reston, VA] : U.S. Geological Survey, 1985. M (230) 49 1985s2

Approximate potentiometric surface for the aquifer unit A3, southeastern coastal plain aquifer system of the United States, prior to development. [Reston, VA]: U.S. Geological Survey, 1985.

$M(230) 49$ i $1985 \mathrm{~s}$ 
WATER, UNDERGROUND--SOUTHERN STATES.

Ground-water quality data from the northern Mississippi embayment : Arkansas, Missouri, Kentucky, Tennessee, and Mississippi. Nashville, Tenn. : U.S. Geological Survey, 1985. (200) R290 no.85-683

WATER, UNDERGROUND--TEXAS--TRAVIS COUNTY .

Woodruff, C. M. Hydrogeology of the Edwards--Barton Springs segment, Travis and Hays counties, Texas. Austin, Tex. : Austin Geological Society, [1984?]

G (245) G938 no.6

WATER, UNDERGROUND--UNITED STATES.

Overview of state ground-water program summaries / [compiled by U.S.

Environmental Protection Agency (EPA), Office of Ground-water Protectionl. Washington, D.C.: The Agency, 1985-

$P(200)$ En85go

WATER, UNDERGROUND--UTAH--PRICE RIVER WATERSHED.

Hydrology of the Price River Basin, Utah with emphasis on selected coal-field areas. Washington : U.S. G.P.O., 1986.

(200) G no.2246 D MP

WATER, UNDERGROUND--WASHINGTON (STATE) --COLUMBIA RIVER REGION--MAPS.

Bauer, H. H. Ground-water levels in the Columbia River basalt and overlying materials, spring 1983, Southeastern Washington State. ITacoma, Wash.] : U.S. Geological Survey, 1985.

$M(284) 49$ So88b

WATER, UNDERGROUND--WASHINGTON (STATE) --ISLAND COUNTY--MAPS.

Jones, M. A. Occurrence of ground water and potential for seawater intrusion, Island County, Washington. [Reston, Va.] : U.S. Geological Survey, 1985 .

$M(284) 49^{\prime} I S 4 j$

WATER, UNDERGROUND--WYOMING--HIGH PLAINS REGION--MAPS.

Avery, Charles. Generalized potentiometric-surface map of the High Plains aquifer in Wyoming, 1981. Cheyenne, Wyo. : U.S. Geological survey, 1984. $M(282) 49 \mathrm{H} 537 \mathrm{a}$

WATER, UNDERGROUND--WYOMING--LARAMIE COUNTY--MAPS.

Crist, Marvin A. Altitude and configuration of the water table, and depth to water near Cheyenne, Wyoming, May 1984. Cheyenne, Wyo. : U.S. Geological survey, 1985.

M (282) 49 C428C

WATER USE--ARKANSAS--MAPS.

Hall, A. P. Water use in Arkansas, 1981. [Little Rock, Ark.] : U.S. Geological Survey, 1984.

M (241) $7931981 \mathrm{~h}$

WATER USE--COLORADO RIVER WATERSHED, UTAH--LINEAR PROGRAMMING.

Water as a factor in energy resources development. Logan, Utan : Utah Water Research Laboratory, College of Engineering, Utah'State University, [1975]

$P(273)$ qut233pj no. 028-1 
WATER USE--MARYLAND--MAPS.

Wheeler, Judith C. Water use in Maryland. [Baltimore?] : State of

Maryland, Department of Natural Resources, Maryland Geological Survey, 1983. M (225) $7931983 w$
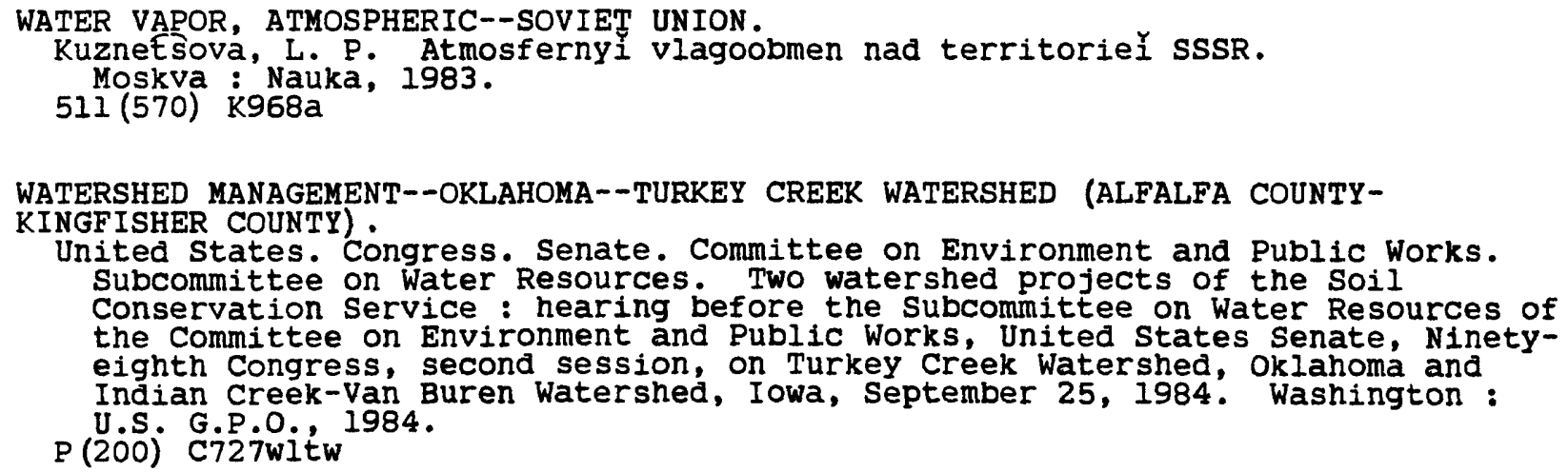

WESTERN AUSTRALIA--GEOLOGY, ECONOMIC--HAMERSLEY BASIN.

Blight, D. F. Economic potential of the lower Fortescue Group and adjacent units in the southern Hamersley Basin: a study of depositional environments. Perth, W.A. : Government Printing Office, 1985.

(860) R no.13

WILDERNESS AREAS--UNITED STATES.

Program review and status report : mineral surveys by the Geological survey and the Bureau of Mines of certain lands managed by the Bureau of Land Management. [Reston, VA]: U.S. Geological Survey, [1986]

(200) R290 no.86-165 D MP

WILDERNESS AREAS--UTAH.

United States. Bureau of Land Management. Utah State Office. Utah BL.M statewide wilderness environmental impact statement : draft. [Salt Lake City, Utan?] : The Office, 1985 [i.e. 1986]

$585.3(273)$ Un 34 uwd

X-RAY DIFFRACTION--PERIODICALS .

Powder diffraction. Powder diffraction. Swarthmore, Pa. : JCPDS International Centre for Diffraction Data, 1986-

886 P868

YELLOWSTONE NATIONAL PARK--CLIMATE.

Dirks, Richard A. The Climate of Yellowstone and Grand Teton National Parks. Washington, D.C. : U.S. Department of the Interior, National Park Service, 1982

$512(282)$ D $628 \mathrm{C}$ MP

YUKON TERRITORY--GEOLOGY.

Carne, R. C. Geological setting and stratiform lead-zinc-barite mineralization Tom Claims, Macmillan Pass, Yukon Territory. Hul1, Québec : Minister of Supply and Services Canada : Canadian Govt. Pub. Centre, 1979

$P(100)$ N820 no.1979-4 
ZOOLOGY--TANZANIA--SELOUS GAME RESERVE.

Matthiessen, Peter. Sand rivers. New York : Viking Press, 1981. $970(774)$ M422s 